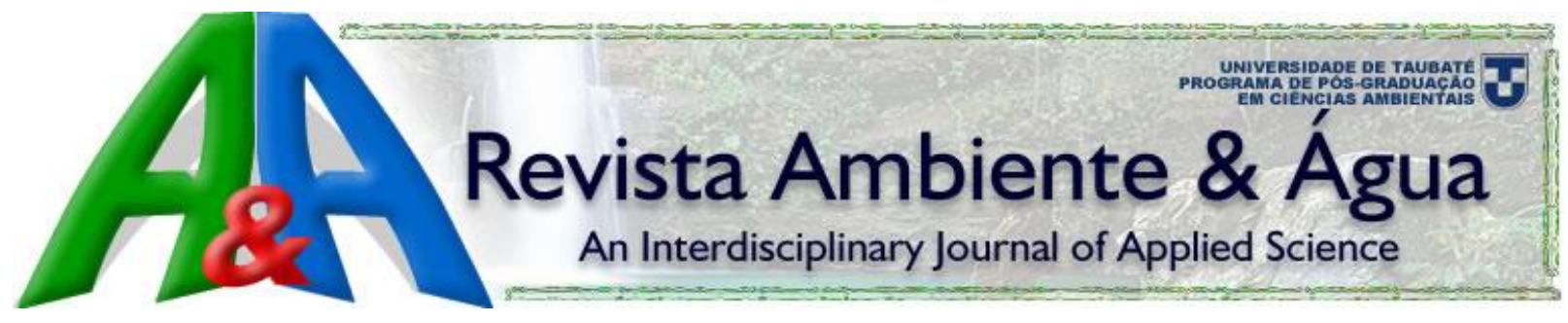

a)

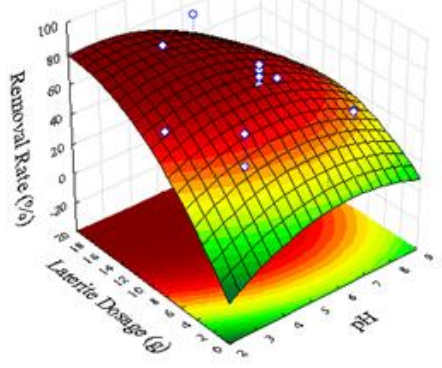

c)

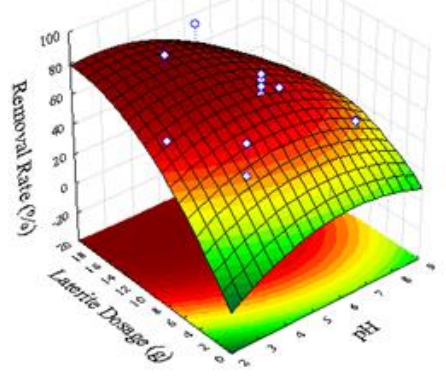

b)
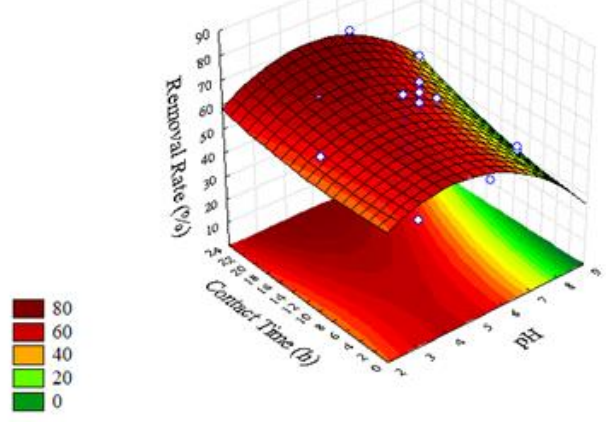

$6^{\text {th }}$ Edition of Revista Ambiente \& Água - An Interdisciplinary Journal of Applied Science, Taubaté, V. 16, N. 6, p. 1-15 Nov/Dec. 2021. (doi:10.4136/ambi-agua.v16.n6) 


\section{EDITORIAL BOARD}

\section{Editors}

Getulio Teixeira Batista (Emeritus Editor) Universidade de Taubaté - UNITAU, BR

Nelson Wellausen Dias (Editor-in-Chief), Fundação Instituto Brasileiro de Geografia e Estatística - IBGE, BR

Ana Aparecida da Silva Almeida

Marcelo dos Santos Targa

Andrea Giuseppe Capodaglio

Arianna Callegari

Antonio Teixeira de Matos

Apostol Tiberiu

Claudia M. dos S. Cordovil

Dar Roberts

Giordano Urbini

Gustaf Olsson

Hélio Nobile Diniz

Ignacio Morell Evangelista

János Fehér

Julio Cesar Pascale Palhares

Luis Antonio Merino

Maria Cristina Collivignarelli

Massimo Raboni

Petr Hlavínek

Richarde Marques da Silva

Stefan Stanko

Teresa Maria Reyna

Yosio Edemir Shimabukuro

Zhongliang Liu Beijing

Text Editor

Reference Editor

Peer-Reviewing Process

System Analyst

Secretary and Communication

\section{Associate Editors}

Universidade de Taubaté (UNITAU), BR

Universidade de Taubaté (UNITAU), BR

\section{Editorial Commission}

University of Pavia, ITALY

Università degli Studi di Pavia, ITALY

Universidade Federal de Minas Gerais (UFMG), BR

University Politechnica of Bucharest, Romênia

Centro de estudos de Engenharia Rural (CEER), Lisboa, Portugal

University of California, Santa Barbara, United States

University of Insubria, Varese, Italy

Lund University, Lund, Sweden

Inst. Geológico, Sec. do Meio Amb. do Est. de SP (IG/SMA), BR

University Jaume I- Pesticides and Water Research Institute, Spain

Debrecen University, Hungary

Embrapa Pecuária Sudeste, CPPSE, São Carlos, SP, BR

Institute of Regional Medicine, National University of the Northeast, Corrientes, Argentina

University of Pavia, Depart. of Civil Engineering and Architecture, Italy

LIUC - University "Cattaneo", School of Industrial Engineering, Italy

Brno University of Technology República Tcheca

Universidade Federal da Paraíba (UFPB), BR

Slovak Technical University in Bratislava Slovak, Eslováquia

Universidad Nacional de Córdoba, Argentina

Instituto Nacional de Pesquisas Espaciais (INPE), BR

University of Technology, China

Theodore D`Alessio, FL, USA, Maria Cristina Bean, FL, USA

Liliane Castro, Bibliotecária - CRB/8-6748, Taubaté, BR

Marcelo Siqueira Targa, UNITAU, BR

Tiago dos Santos Agostinho, UNITAU, BR

Luciana Gomes de Oliveira, UNITAU, BR

\section{Library catalog entry by Liliane Castro CRB/8-6748}

Revista Ambiente \& Água - An Interdisciplinary Journal of Applied Science / Instituto de Pesquisas Ambientais em Bacias Hidrográficas. Taubaté. v. 16, n.6 (2006) - Taubaté: IPABHi, 2021.

Quadrimestral (2006 - 2013), Trimestral (2014 - 2016), Bimestral (2017), Publicação Contínua a partir de Janeiro de 2018.

Resumo em português e inglês.

ISSN 1980-993X

1. Ciências ambientais. 2. Recursos hídricos. I. Instituto de Pesquisas Ambientais em Bacias Hidrográficas.

CDD - 333.705

CDU - (03)556.18 


\section{TABLE OF CONTENTS}

\section{COVER:}

In this research, the use of laterite in natura for the removal of phosphorus in domestic effluents was investigated. The three parts of this graphic illustrate the interaction of the variables used in the study as follows: a) dosage of adsorbent material and $\mathrm{pH}$; b) $\mathrm{pH}$ and contact time; and, c) dosage of adsorbent material and contact time in relation to the removal rate of phosphorus. The best adsorption occurred at pH 4 and other low pH values. High pH conditions affect the surface load of the adsorbent decreasing the adsorption rate. Laterite proved to be effective for the removal of phosphorus in synthetic effluents and can be used in filtering units to remove pollutants. Simplified techniques such as this can be used to meet the demand of the population without access to water treatment and distribution. Source: SOARES, A.C.Da.S. et al. Low-cost material as active substrates for the removal of phosphorus in synthetic effluents: a proposal for social treatment technology. Rev. Ambient. Água, Taubaté, vol. 16 n. 6, p. 1-15, 2021. doi:10.4136/ambi-agua.2770

\section{ARTICLES}

Impacts of dam construction on the macroinvertebrate community in the Poxin-Açú, in a tropical region

01 doi:10.4136/ambi-agua.2704

Anderson Nascimento do Vasco; Amanda Vaz de Souza Oliveira; Geovane Alves Feitosa;

Talita Guimarães Araújo-Piovezan; Agripino Emanuel Oliveira Alves; José Oliveira Dantas

Low-cost material as active substrates for the removal of phosphorus in synthetic effluents: a proposal for social treatment technology

02 doi:10.4136/ambi-agua.2770

Ana Caroline da Silva Soares; Liliana Pena Naval

Saline waters and nitrogen/potassium fertilization combinations on physiological aspects and production of West Indian cherry

03 doi:10.4136/ambi-agua.2780

Evandro Manoel da Silva; Hans Raj Gheyi; Reginaldo Gomes Nobre; Geovani Soares de Lima; Lauriane Almeida dos Anjos Soares; Benedito Ferreira Bonifácio

Outflow adjustment coefficient for the design of storage facilities using the rain envelope method applied to Brazilian state capitals

04 doi:10.4136/ambi-agua.2707

Diego Marangoni Santos; Joel Avruch Goldenfum; Fernando Dornelles

Hydrological regionalization of streamflows for the Tocantins River Basin in Brazilian Cerrado biome

05 doi:10.4136/ambi-agua.2716

Jéssica Assaid Martins Rodrigues; Marcelo Ribeiro Viola; Carlos Rogério de Mello; Marco Antônio Vieira Morais

\begin{tabular}{ll}
\hline $06 \quad$ Removal of nutrients from aquaculture residual water: A review \\
doi:10.4136/ambi-agua.2747 \\
Jéssica Medeiros Ribeiro Cargnin; Jair Juarez João \\
\hline Interaction of precipitation with tree canopy increases nutrient input \\
doi:10.4136/ambi-agua.2761 \\
Gian Carlos Poleto; Dione Richer Momolli; Mauro Valdir Schumacher; Aline Aparecida Ludvichak; \\
Kristiana Fiorentin dos Santos; Márcio Viera; Clayton Alcarde Alvares; James Stahl \\
Artificial floating islands as a tool for the water quality improvement of fishponds \\
doi:10.4136/ambi-agua.2734 \\
Livia João Alexandre Saviolo Ostil; Claudinei José Rodrigues; Clovis Ferreira do Carmo; Ana Carolina \\
Peixoto; Sergio Henrique Canello Schalch; Adriana Sacioto Marcantonio; Fernanda Menezes França; \\
Cacilda Thais Janson Mercante
\end{tabular}


Spatial variability of soil erodibility in pastures and forest areas in the municipality of Porto Velho, Rondônia

Lucivânia Izidoro da Silva; Milton César Costa Campos; Wildson Benedito Mendes Brito; José Maurício da Cunha; Alan Ferreira Leite de Lima; Luís Antônio Coutrim dos Santos; Abdul Luís Hassane

Effect of turbidity on ultraviolet disinfection of domestic wastewater for agricultural reuse

Diego Fernando Atoche Garay; Lisiana Crivelenti Voltolini; Reinaldo Gaspar Bastos;

Claudinei Fonseca Souza

Filling and validating rainfall data based on statistical techniques and artificial intelligence

11 doi:10.4136/ambi-agua.2767

Camila Bermond Ruezzene; Renato Billia de Miranda; Talyson de Melo Bolleli; Frederico Fábio Mauad 


\begin{tabular}{|c} 
Ambiente \& Água - An Interdisciplinary Journal of Applied Science \\
ISSN 1980-993X - doi:10.4136/1980-993X \\
www.ambi-agua.net \\
E-mail: ambi.agua@gmail.com
\end{tabular}

\title{
Reviewers of Volume 16, 2021 of Revista Ambiente \& Água
}

\section{Scientific Reviewers}

\author{
doi:10.4136/ambi-agua.2688 \\ Nelson Wellausen Dias \\ Editor of Revista Ambiente \& Água \\ E-mail: ambi.agua@gmail.com
}

The list of reviewers who voluntarily dedicated part of their time to review submissions for Revista Ambiente \& Água's Volume 16, 2021 is presented in Table 1. This list includes manuscripts that were accepted and published in one of the six annual issues and also manuscripts submitted and rejected up to November 01, 2021. It may therefore include the names of reviewers that completed their evaluations between December, 2020 and November, 2021.

We are deeply indebted to all of them that voluntarily and anonymously devoted part of their time to support our journal and delivered an immense contribution to the quality of the published papers. We gratefully acknowledge their professional work and outstanding product.

Table 1. Ad Hoc Peer Reviewers that evaluated submissions for the 2021 edition of Revista Ambiente \& Água, Volume 16, n. 1, 2, 3, 4, 5, and 6.

Aabid Hussein Mir

Abbas Roozbahani

Abdelkader Hamlat

Abdeslam Ennabili

Abid Ali Khan

Adornis Dakarai Nciizah

Adriano Valentim Diotto

Ahmed Fadili

Ahmet Aygun

Alfonso Aguilar

Alírio E. Rodrigues

Alpina Begossi

Amey Tilak

Amin Mojiri

Ana-Maria Stanescu

Anderson Schwingel Ribeiro
University of Kashmir, Srinagar, India

University of Tehran, Tehran, Iran (the Islamic Republic of)

Université Amar Telidji Laghouat, Laghouat, Algeria

Université Sidi Mohamed Ben Abdellah, Fes, Morocco

Indian Institute of Technology, Delhi, India

Agricultural Research Council, Pretoria, South Africa

Universidade Federal de Lavras (UFLA), Lavras, MG, Brazil

Ibn Zohr University of Agadir, Ouarzazate, Morocco

Bursa Technical University, Yıldırım, Turkey

Universidad Autónoma de Yucatán, Merida, Mexico

Universidade do Porto, Porto, Portugal

Universidade Estadual de Campinas (UNICAMP), Campinas, SP, Brazil

Limerick Institute of Technology, Thurles, Ireland

Hiroshima University,Higashihiroshima, Japan

Institute for Soil Science Agrochemistry and

Environment, Bucuresti, Romania

Universidade Federal de Pelotas (UFPEL), Pelotas, RS, Brazil 
Andre Evette

Andrea G. Capodaglio

Anita Lakhani

Anita Raimondi

Arieke Jan Janse Janse

Arif Ali Baig Moghal

Asia L. Dowtin

Bahram Choubin

Bouderbala Abdelkader

Bruno Mantovanelli

Carmen Zaharia

Christopher Neill

Claude Hammecker

Claudia Ribeiro

Cristhiane Michiko Okawa

Daniel Cozzolino

Dao Nguyen Khoi

Dave Morris

David Langat

David Omole

Deb Raj Aryal

Domingos Sávio Rodrigues

Duran Yavuz

Edison Barbieri

Eduardo Collares

Eladl Eltanahy

Elisa Kochskämper

Elisabete de Santis Braga

Elzbieta Zebek

Emanuele Barca

Enedir Ghisi

Ergo Rikmann
Institut National De Recherche En Sciences Et

Technologies Pour L'environnement Et L'agriculture, Paris, France

University of Pavia, Corso, Pavia, Italy

Dayalbagh Educational Institute, Agra, India

Politecnico di Milano, Como, Lombardia, Italy

Netherlands Environmental Assessment Agency, Den Haag, Netherlands

National Institute of Technology Warangal, Warangal, India

Michigan State University, Michigan, United States

West Azarbaijan Agricultural and Natural Resources Research and Education Center, AREEO, Urmia, Iran

Université Djilali Bounaama de Khemis Miliana, Khemis Miliana, Algeria

Universidade Federal de Santa Maria (UFSM), Santa Maria, RS, Brazil

Technical University Gheorghe Asachi Iasi, Iasi, Romania

Brown University, Providence, United States

Institut de recherche pour le développement, Montpellier, France

Cooperativa de Ensino Superior Politécnico e Universitário, Gandra, Portugal

Universidade Estadual de Maringá (UEM), Maringá, PR, Brazil

The University of Queensland, Saint Lucia, Australia

Ho Chi Minh City University of Science, Ho Chi Minh City, Viet Nam

Ontario Ministry of Natural Resources and Forestry, Picton, Ontario, Canada

Kenya Forest Service, Kericho, Kenya

Covenant University, Ota, Nigeria

Consejo Nacional de Ciencia y Tecnología, Villaflores, Ciudad de México, Mexico

Instituto de Botânica (IBT), São Paulo, SP, Brazil

Selcuk Universitesi, Selçuklu/Konya, Turkey

Instituto de Pesca (IP), Moema, SP, Brazil

Universidade do Estado de Minas Gerais (UEMG), Passos, MG, Brazil

Mansoura University, Mansoura, Egypt

Leibniz-Institut für Raumbezogene Sozialforschung, Erkner, Germany

Universidade de São Paulo (USP), São Paulo, SP, Brazil

University of Warmia and Mazury in Olsztyn, Olsztyn, Poland

Water Research Institute, Bari, Italy

Universidade Federal de Santa Catarina (UFSC),

Florianópolis, SC, Brazil

University of Tartu, Tartu, Estonia 
Erika Beilicci

Ernesto Brugnoli

Evlyn Novo

Fábio Marin

Fabrício Menezes Ramos

Fadime Karaer

Farshid Ghanbari

Fernanda Garcia Sampaio

Fernando Pacheco-Torgal

Francisco Agrela

Francisco Gabriel Acien-Fernandez

Francisco Sávio Gomes Pereira

German Tortosa

Hamidi Abdul Aziz

Hani Mansour

Haydar Demirhan

Hebe Morganne Campos Ribeiro

Helenita Corrêa Ely

Herly Carlos Teixeira Dias

Hooshyar Hossini

Ian Forster

J. Aaron Hogan

Jalil Jaafari

Jochen Hack

Jon Molinero

José Alves Junqueira Júnior

Juan A. Conesa

Julio Cesar Demarchi

Junjie Niu

Kalman Imre
The Polytechnic University of Timisoara, Timisoara, Romania

Universidad de la República Uruguay, Montevideo, Uruguay

Instituto Nacional de Pesquisas Espaciais (INPE), São José dos Campos, SP, Brazil

Escola Superior de Agricultura "Luiz de Queiroz" (ESALQ/USP), Piracicaba, SP, Brazil

Instituto Federal da Bahia (IFBA), Valença, BA, Brazil Eskişehir Teknik Üniversitesi, Eskisehir, Turkey

Abadan School of Medical Sciences, Abadan, Iran (the Islamic Republic of)

Empresa Brasileira de Pesquisa Agropecuária (EMBRAPA), Jaguariúna, SP, Brazil

Universidade do Minho, Fundão, Portugal

Universidad de Cordoba, Cordoba, Spain

Universidad de Almería, La Cañada, Almeria, Spain

Instituto Federal de Educação, Ciência e Tecnologia de Pernambuco (IFPE), Recife, PE, Brazil

Zaidín Experimental Station, Granada, Spain

Universiti Sains Malaysia, Nibong Tebal, Malaysia

Southern Illinois University Carbondale, Giza, Egypt

Royal Melbourne Institute of Technology (RMIT), Melbourne, Australia

Universidade do Estado do Pará (UEPA), Belém, PA, Brazil

Pontifícia Universidade Católica do Rio Grande do Sul (PUCRS), Porto Alegre, RS, Brazil

Universidade Federal de Viçosa (UFV), Viçosa, MG, Brazil

Kermanshah University of Medical Sciences, Kermanshah, Beheshti Blvd, Iran

Fisheries and Oceans Canada, West Vancovuer, Canada

Florida International University, Miami, United States

Tehran University of Medical Sciences, Tehran, Iran (the Islamic Republic of)

Technische Universität Darmstadt, Darmstadt, Germany

Pontificia Universidad Católica del Ecuador, Esmeraldas, Ecuador Instituto Federal do Sudeste de Minas Gerais (IF Sudeste), Juiz de Fora, MG, Brazil

Universidad de Alicante, San Vicente del Raspeig, Alicante, Spain

Universidade Estadual Paulista (UNESP), Ourinhos, SP, Brazil

University of Wisconsin-Milwaukee, Milwaukee, United States

Banat University of Agricultural Sciences and Veterinary Medicine of Timişoara, Timişoara, Romania 


\begin{tabular}{|c|c|}
\hline Kathleen Aviso & De La Salle University, Manila, Philippines \\
\hline Kirsty Carden & University of Cape Town, Rondebosch, South Africa \\
\hline Klára Báliková & Technical University in Zvolen, Zvolen, Slovakia \\
\hline Konstantinos X. Soulis & Agricultural University of Athens, Athens, Greece \\
\hline Lahiru Wijedasa & $\begin{array}{l}\text { National University of Singapore, Singapore, } \\
\text { Singapore }\end{array}$ \\
\hline Laura Bulgariu & $\begin{array}{l}\text { Technical University Gheorghe Asachi Iasi, Iasi, } \\
\text { Romania }\end{array}$ \\
\hline Leandro Juen & $\begin{array}{l}\text { Universidade Federal do Pará (UFPA), Belém, PA, } \\
\text { Brazil }\end{array}$ \\
\hline Luiz Fernando Romanholo Ferreira & Universidade Tiradentes (UNIT), Aracajú, SE, Brazil \\
\hline M.S. Abinawanto & Universitas Indonesia, Depok, Indonesia \\
\hline Madan M Mahanty & $\begin{array}{l}\text { National Institute of Ocean Technology, Chennai, } \\
\text { India }\end{array}$ \\
\hline Manoelito Ferreira Silva Junior & $\begin{array}{l}\text { Universidade Estadual de Ponta Grossa (UEPG), Ponta } \\
\text { Grossa, PR, Brazil }\end{array}$ \\
\hline Manuel Soto & Universidade da Coruña, A Coruña, Spain \\
\hline Marcelo Paulino & $\begin{array}{l}\text { Universidade Federal do Tocantins (UFT), Araguaína, } \\
\text { TO, Brazil }\end{array}$ \\
\hline Marek Zivcak & $\begin{array}{l}\text { Slovak university of agriculture in Nitra, Nitra- } \\
\text { Chrenová, Slovakia }\end{array}$ \\
\hline Maria Alejandra Herrero & $\begin{array}{l}\text { Asociación Pro Calidad de la Leche y sus derivados, } \\
\text { Olivos, Argentina }\end{array}$ \\
\hline Maria Poca & $\begin{array}{l}\text { Instituto de Matemática Aplicada San Luis, San Luis, } \\
\text { Argentina }\end{array}$ \\
\hline Maria Silva & Universidade CEUMA, São Luís, MA, Brazil \\
\hline Maria Teresa Viseu & $\begin{array}{l}\text { Laboratório Nacional de Engenharia Civil, Lisboa, } \\
\text { Portugal }\end{array}$ \\
\hline Marian Brestic & $\begin{array}{l}\text { Slovak University of Agriculture, Nitra-Chrenová, } \\
\text { Slovakia }\end{array}$ \\
\hline Mark Ferrey & $\begin{array}{l}\text { Minnesota Pollution Control Agency, Minnesota, } \\
\text { United States }\end{array}$ \\
\hline Mark Grismer & University of California at Davis, Davis, United States \\
\hline Martin Thalheimer & $\begin{array}{l}\text { Laimburg Research Centre for Agriculture and } \\
\text { Forestry, Pfatte, Italy }\end{array}$ \\
\hline Marttin Gundupalli Paulraj & $\begin{array}{l}\text { King Mongkut's University of Technology North } \\
\text { Bangkok, Bang Sue, Bangkok, Thailand }\end{array}$ \\
\hline Md Akhtarul Islam & $\begin{array}{l}\text { Shahjalal University of Science, Chemical Engineering } \\
\text { and Polymer Science, Sylhet, Bangladesh }\end{array}$ \\
\hline Mirtha Latsague & $\begin{array}{l}\text { Catholic University of Temuc, Temuco, Araucanía, } \\
\text { Chile }\end{array}$ \\
\hline Mohamed Abdel Daim & Suez Canal University, Ismailia, Egypt \\
\hline Mohammad Najafzadeh & $\begin{array}{l}\text { Graduate University of Advanced Technology, } \\
\text { Kerman, Iran }\end{array}$ \\
\hline Mónica Toro Manríquez & $\begin{array}{l}\text { Centro Austral de Investigaciones Científicas, } \\
\text { Ushuaia, Argentina }\end{array}$ \\
\hline Mostafa Ali Elmadawy & $\begin{array}{l}\text { Kafrelsheikh University, Kafr El Sheikh Governorate, } \\
\text { Egypt }\end{array}$ \\
\hline Motasem Y. D. Alazaiza & Universiti Sains Malaysia, Nibong Tebal, Malaysia \\
\hline Nadjib Drouiche & $\begin{array}{l}\text { Semiconductor Technology Research Center for } \\
\text { Energetics, Algiers, Algeria }\end{array}$ \\
\hline
\end{tabular}


Narendra Kumar Meena

Natália Ueda

Nilantha Hulugalle

Nirjhar Bar

Olatunde Dahunsi

Olga Makarieva

Olli H. Tuovinen

Ouafik Boulariah

Ozekele Ogbeide

Paulo Cesar de Jesus

Rajendra Prasad Singh

Rasmus E. Benestad

Rauf Faroutan

Renata Zylla

Roberta Fulthorpe

Roberto Parra-Saldívar

Robin Harder

Rodrigo Proenca de Oliveira

Roseli Tuan

Rouholah Zare-Dorabei

Shabbir H. Gheewala

Shreeshivadasan Chelliapan

Siamak Behzady

Silvana Popescu

Su Shiung Lam

Taison Anderson Bortolin

Tanika Tanika

Tie Liu

Tongayi Mwedzi

Victor J. Jaramillo
Wadia Institute of Himalayan Geology, Dehradun, Uttarakhand, India

UniCesumar, Maringá, PR, Brazil

The Australian National University, Canberra, Australia

St James School Physics, Kolkata, India

Landmark University, Omu Aran, Nigeria

Melnikov Permafrost Institute, Magadan, Russian Federation

Ohio State University, Columbus, United States

Universita degli Studi di Salerno, Fisciano, Italy

University of Benin, Benin City, Nigeria

Universidade Regional de Blumenau (FURB),

Blumenau, SC, Brazil

Southeast University, Dhaka, Bangladesh

Norwegian Meteorological Institute, Oslo, Norway

University of Tabriz, East Azerbaijan Province, Tabriz, Iran (the Islamic Republic of)

Łukasiewicz Research Network, Brussels, Lodz, Poland.

University of Toronto Scarborough, Scarborough, Toronto, Canada

Instituto Tecnológico e de Estudos Superiores de Monterrey, Monterrey, Mexico

Swedish University of Agricultural Sciences, Uppsala, Sweden

Universidade de Lisboa, Lisboa, Portugal

Superintendência de Controle de Endemias, São Paulo, SP, Brazil

Iran University of Science and Technology, Tehran, Iran (the Islamic Republic of)

King Mongkut's University of Technology Thonburi, Thung Khru, Bangkok, Thailand

Universiti Teknologi Malaysia, Skudai, Johor, Malaysia

Persian Gulf and Oman Sea Ecological Research Institute, Bandar Abbas, Iran (the Islamic Republic of) University of Agricultural Sciences and Veterinary Medicine of Cluj-Napoca, Calea Mănăștur, ClujNapoca, Romania

Universiti Malaysia Terengganu, Kuala Terengganu, Terengganu, Malaysia

Universidade de Caxias do Sul (UCS), Caxias do Sul, RS, Brazil

Wageningen University \& Research, Wageningen, Netherlands

Xinjiang Institute of Ecology and Geography, Urumqi, China

Chinhoyi University of Technology, Chinhoyi, Zimbabwe

Universidad Nacional Autónoma de México, Morelia, Mexico 
Vinicius Sebba Patto

Wei-Bo Chen

Wilson Thau Lym Yong

Yaseen A Hamaamin

Yonggang Liu

Yosio Edemir Shimabukuro

Yuri Lopez Zinn

Zhen Wang
Universidade Federal de Goiás (UFG), Goiânia, GO, Brazil

National Science and Technology Center for Disaster Reduction, New Taipei City, Taiwan

Universiti Malaysia Sabah, Kota Kinabalu, Sabah, Malaysia

University of Sulaimani, Sulaimani, Iraq

University of South Florida, Tampa, Florida, United States

Instituto Nacional de Pesquisas Espaciais (INPE), São José dos Campos, SP, Brazil

Universidade Federal de Lavras (UFLA), Lavras, MG, Brazil

China Water Conservancy Hydropower Science Academe, Haidian District, Beijing, China

Note: 1) Some of these reviewers evaluated more than one manuscript;

2) This list includes reviewers that evaluated submissions that were not accepted for publication, in addition to the ones published in 2021 .

According to the information presented in Table 2, 115 reviewers are from international institutions. This is an indication that our journal is gaining international relevance and dissemination.

Table 2. Number and type of institutions of reviewers that contributed to Volume 16, 2021.

\begin{tabular}{|c|c|c|c|c|c|c|}
\hline \multicolumn{5}{|c|}{ From Brazil } & \multicolumn{2}{|l|}{ From abroad } \\
\hline $\begin{array}{c}\text { Federal } \\
\text { Universities }\end{array}$ & $\begin{array}{c}\text { State } \\
\text { Universities }\end{array}$ & $\begin{array}{c}\text { State/Federal } \\
\text { Institutions }\end{array}$ & $\begin{array}{c}\text { National } \\
\text { private } \\
\text { Universities }\end{array}$ & $\begin{array}{l}\text { Municipal } \\
\text { Universities }\end{array}$ & $\begin{array}{c}\text { Reviewers from } \\
\text { international Institutions }\end{array}$ & Total \\
\hline 9 & 8 & 9 & 6 & 0 & 115 & 147 \\
\hline
\end{tabular}




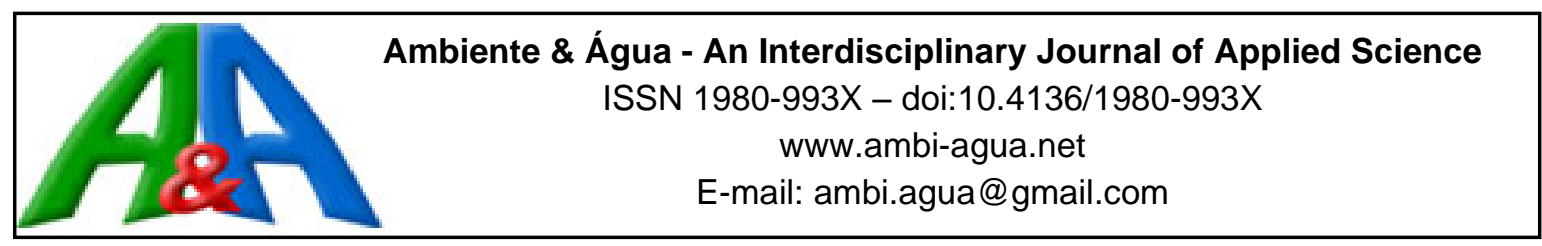

\title{
Impacts of dam construction on the macroinvertebrate community in the Poxin-Açú, in a tropical region
}

\author{
ARTICLES doi:10.4136/ambi-agua.2704
}

Received: 01 Feb. 2021; Accepted: 04 Oct. 2021

\author{
Anderson Nascimento do Vasco ${ }^{1 *}$; ; Amanda Vaz de Souza Oliveira1 ${ }^{1}$; \\ Geovane Alves Feitosa ${ }^{1}$; ; Talita Guimarães Araújo-Piovezan ${ }^{2}$; \\ Agripino Emanuel Oliveira Alves ${ }^{1}$; ; José Oliveira Dantas ${ }^{2}$ ic \\ ${ }^{1}$ Departamento de Agroecologia. Instituto Federal de Educação, Ciência e Tecnologia de Sergipe (IFS), \\ Rodovia BR 101, Km 96, s/n, CEP: 49100-000, São Cristóvão, SE, Brazil. \\ E-mail:vazdesouza.o@gmail.com,geovane_feitosa@hotmail.com, aeoalves@gmail.com \\ ${ }^{2}$ Departamento de Biologia. Instituto Federal de Educação, Ciência e Tecnologia de Sergipe (IFS), \\ Rodovia BR 101, Km 96, s/n, CEP: 49100-000, São Cristóvão, SE, Brazil. \\ E-mail: talit_a@hotmail.com, josedantas336@gmail.com \\ *Corresponding author. E-mail: anderson.vasco@ifs.edu.br
}

\begin{abstract}
River regularization plays an important role in socio economic development. However, it also modifies the natural flow system of the river and its biotic and abiotic characteristics, causing significant impacts on rivers. To evaluate the impacts on the macroinvertebrate community caused by dam construction on the Poxim-Açú River, metrics of composition and community structure of the macroinvertebrates were analyzed, as well as ecological and biological traits of the region. Macroinvertebrates were collected at three sites located downstream the dam, before (2013) and after (2015) dam construction. The water quality was classified as "good" to "excellent" according to the biotics indices. The alterations of the flow regime of the river after the dam construction influenced the macroinvertebrate communities, modifying their diversity, equitability, richness, and the number of individuals.
\end{abstract}

Keywords: bioindicators, dam impacts, environmental monitoring.

\section{Impactos da construção de barragem na comunidade de macroinvertebrados no rio Poxim-Açu numa região tropical}

\begin{abstract}
A regularização de rios tem papel fundamental para o desenvolvimento socioeconômico de uma região, porém resulta em alterações em larga escala no regime de fluxo natural e modifica potencialmente uma ampla gama de fatores abióticos e bióticos, sendo considerado um dos impactos ambientais mais significativo nos rios em todo o mundo. Este estudo tem como objetivo avaliar os impactos na comunidade de macroinvertebrados ocasionado pela construção de uma barragem para armazenamento de água no rio Poxím-Açú, bem como características biológicas e ecológicas locais. Foram realizadas coletas de macroinvertebrados em três pontos a jusante da barragem em dois períodos distintos: anterior a construção da barragem (2013) e posterior a barragem (2015). A qualidade da água foi classificada como de boa e excelente qualidade, respectivamente, por meio dos índices bióticos. Alterações nas


comunidades de macroinvertebrados foram observadas devido as modificações do regime de vazão, como resultado da construção da barragem, que influenciou na composição e estrutura das comunidades de macroinvertebrados e se reflete nas mudanças na diversidade, equitabilidade, riqueza e número de indivíduos no período anterior e posterior a barragem.

Palavras-chave: bioindicadores, impactos de barragens, monitoramento ambiental.

\section{INTRODUCTION}

In the last two decades, it has become evident that several anthropic activities in aquatic environments are connected with the imbalance of biological communities (Camargo et al., 2019). Among them, the damming of the rivers potentially modifies various biotic and abiotic conditions in the lotic ecosystems, being considered one of the most significant anthropic impacts on rivers worldwide (Tonkin et al., 2018; Krajenbrink et al., 2019).

Dam construction could discontinue the connections between habitats upstream and downstream of the river (Dynesius and Nilsson, 1994), altering physical, chemical, and biological components of the lotic and lentic environments (Brooks et al., 2018). Generally, physical impacts are related to the flow regime of the river, water temperature, water transparency, and reduction of sediments downstream of the dam (White et al., 2017; Wu et al., 2019). The most common chemical impacts are the reduction of dissolved oxygen in water and the reduction of phosphorus and nitrogen nutrients. The biological impacts could be related to the avoidance of migratory movement, reduction of the reproduction rate, reduction of the physiological efficiency due to the absence of oxygen, shifts in the diet pattern of the species, increase in the abundance of the most dominant and tolerant species, facilitation for the colonization process and establishment of exotic species.

To monitor environmental quality, aquatic macroinvertebrates are generally used, since several groups of these animals are highly sensitive to anthropogenic changes (Baptista, 2008). Macroinvertebrates are useful indicators, due to their specificity with certain types of impacts, as many species are demonstrably sensitive to one type of pollutant, or more tolerant to others (Pompeu et al., 2005). Most studies around the world discuss the effect of dam construction on the ecological structure of the aquatic communities (Wang et al., 2019).

However, there is a lack of this information on tropical regions, especially related to the Brazilian Northeast portion; direct comparison between macroinvertebrate communities in the periods before and after the construction of the dam has been impossible due to the absence of monitoring data (Maynard and Lane, 2012). Most studies have compared sites downstream of dams with control sites that do not represent natural conditions downstream (Holt et al., 2015). On the other hand, this work compares macroinvertebrate occurrence data downstream of the reservoir before and after the damming of the river.

The main objective was to identify differences in the structure and composition of the macroinvertebrate community related to the construction of the Jaime Umbelino de Souza Dam on the Poxim-Açú River.

\section{MATERIAL AND METHODS}

\subsection{Study site}

The Poxim-Açu River is the main tributary of the hydrological basin of the Sergipe River $\left(10^{\circ} 55^{\prime} \mathrm{S}, 37^{\circ} 12^{\prime} \mathrm{W}\right)$. The micro-basin has an area of $128,08 \mathrm{~km}^{2}$, with a main river channel of $26.7 \mathrm{~km}$ and an altitude range of $478 \mathrm{~m}$ (Figure 1). It is possible to observe different land cover and land uses over the Poxim-Açú River course, including livestock (50.30\%), seasonal forest $(36.56 \%)$, cultivated agricultural areas, exposed soil $(6.97 \%)$, riparian forest $(3.11 \%)$, and degraded areas (2.31\%) (Rocha et al., 2014). 

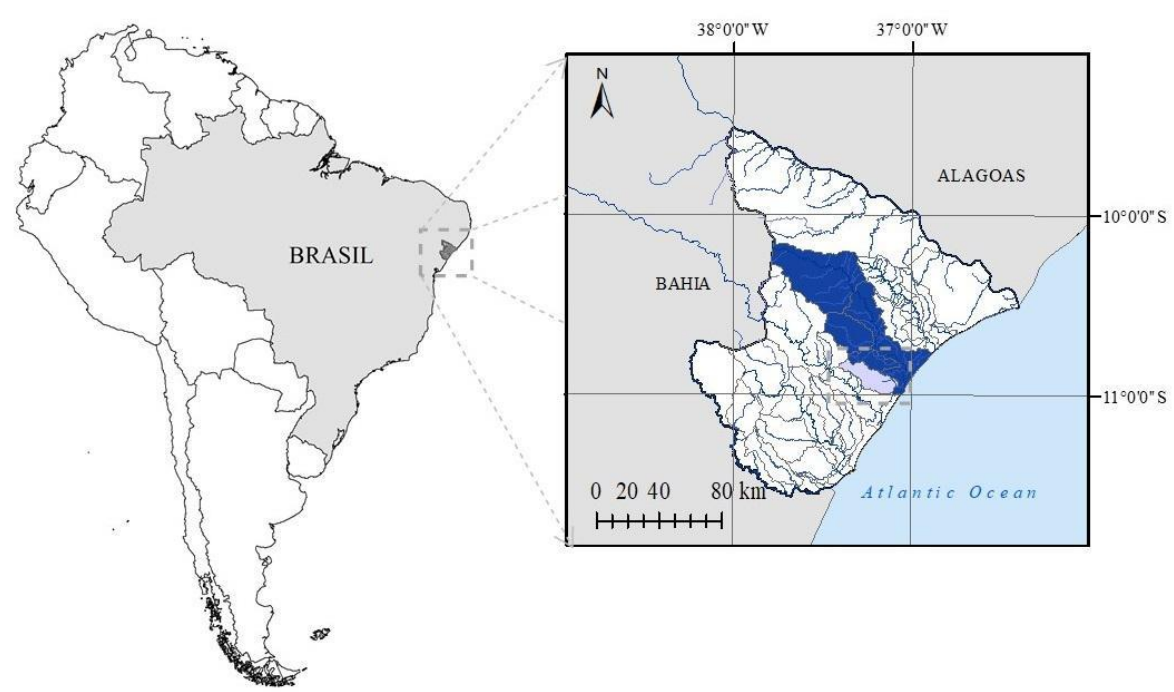

Figure 1. Representation of the Poxim-Açu River Basin, showing the location of the data collection downstream from the dam.

The region has a humid tropical climate, with a dry season from August to March and a rainy season from April to July, with an annual average precipitation varying from 1,600 to $1,900 \mathrm{~mm}$ and annual average temperature of $27^{\circ} \mathrm{C}$, varying from 23 to $31^{\circ} \mathrm{C}$. The Jaime Umbelino de Souza Dam was built over the Poxim-Açu River in Sergipe, and it was inaugurated in 2013 for the purpose of water storage. The dam is located at Timbo's village, Municipality of São Cristóvão, Sergipe department. The dam's reservoir has an area of $5.2 \mathrm{~km}^{2}$ and a water storage capacity of 32 million cubic meters (Rocha et al., 2014).

\subsection{Insects Collection}

Collection of macroinvertebrates and abiotic data was carried out monthly in three places on the river in the period before (January to August 2013) and after (August 2014 to July 2015) dam construction. The characteristics of the sampling points downstream of the dam with average distances of $300 \mathrm{~m}$ were: Point $1\left(10^{\circ} 55^{\prime} 183^{\prime \prime} \mathrm{S}, 37^{\circ} 11^{\prime} 264^{\prime \prime} \mathrm{W}\right.$, altitude $\left.38 \mathrm{~m}\right)$ presenting substrate with pebbles and gravel, with less than $5 \%$ of the disposal of the sludge at the bottom of the river and a lack of it at the backwaters. More than $50 \%$ of the river bottom has diversified habitats with the presence of submerged trunks and gravel. There are changes in the river channel with the opening of ditches, felled trees, related to the channeling of the dam's mains, dragging sediment, and contributing to the siltation of the river.

Point $2\left(10^{\circ} 55^{\prime} 188^{\prime \prime} \mathrm{S}, 37^{\circ} 11^{\prime} 180^{\prime \prime} \mathrm{W}\right.$, altitude $\left.30 \mathrm{~m}\right)$ - substrate mainly composed of gravel and some pebbles. Ten to $30 \%$ of the habitats are stable, but substrates are frequently modified by anthropic actions that increase gravel, sand, and sludge disposal. In addition, 5 to $30 \%$ of the river bottom is affected by these actions, causing some disposal at the river's backwaters.

Point $3\left(10^{\circ} 55,195^{\prime}\right.$ and $S 37^{\circ} 11,119^{\prime} \mathrm{W}$ altitude $\left.27 \mathrm{~m}\right)$ - a substrate formed by gravel, sand, and some pebbles is predominant. The type of bottom is considered medium, where there are 10 to $30 \%$ of stable habitats; substrate frequently modified mainly by increasing gravel, sand or mud; 5 to $30 \%$ of the affected amount; gentle deposition in the backwaters.

The insects were collected using a " $D$ " net with a $0.05 \mathrm{~mm}$ mesh opening over marginal vegetation, bottom sediments, and water column. The entomological material was sorted in the field with the help of tweezers, plastic trays and placed in bottles with $70 \%$ alcohol. The material was taken to the Entomology Laboratory of the Federal Institute of Sergipe, Campus São Cristóvão, and identified at the family level with the aid of a stereoscopic microscope and specialized literature (Magnai et al., 2010). 


\subsection{Biotic Index and Data Analysis}

Initially, all data were evaluated for normality using the Shapiro-Wilk test, aiming to determine the application of parametric or nonparametric analyses. To assess the diversity of the three sampling points, the total richness $(\mathrm{S})$, Shannon-Wiener Log Base 10 index $\left(\mathrm{H}^{\prime}\right)$, Pielou equitability $\left(\mathrm{J}^{\prime}\right)$, and the dominance of the main taxon $(\mathrm{k})$ were used. The latter is defined by the percentage of occurrence of the most abundant taxon with the others. To determine these indices, the PAST Software was used (Hammer, 2017).

To assess water quality, the Biological Monitoring Working Party (BMWP) index was applied. This index is a scale from 1 to 10 , along which the sensitivity of various insect and other macroinvertebrate families are scored, with the highest scores assigned to species most sensitive to organic pollution. To interpret the total scores of the BMWP index, the table of values proposed by Alba-Tercedor (1996) was used, correlating these values to the water quality in the three sampling points shown respectively (Table 1).

Table 1. BMWP index scores interpretation according to Alba-Tercedor (1996).

\begin{tabular}{ccc}
\hline Class & BMWP & Water quality \\
\hline 1 & $>150$ & Excellent \\
2 & $101-120$ & Good (Acceptable) \\
3 & $36-60$ & Medium (Doubtful) \\
4 & $16-35$ & Bad (Critical) \\
5 & $<15$ & Very Bad (Very Critical) \\
\hline
\end{tabular}

Another index used was the EPT (proportion of Ephemeroptera, Plecoptera, and Trichoptera), where all organisms of the orders Ephemeroptera, Plecoptera, and Trichoptera present in the sample are considered, and the relative abundance of these orders concerning the total number of organisms in the sample is calculated, the result is obtained through the Equation 1:

$$
E P T \%=\frac{n^{\circ} \text { Indivíduos (Ephemeroptera }+ \text { Plecoptera }+ \text { Trichoptera) }}{n^{\circ} \text { total de indivíduos }} \times 100
$$

The result of this index is compared with the values that Gonçalves (2011) proposed (Table 2) below.

Table 2. EPT index scores interpretation, according to Gonçalves (2011).

\begin{tabular}{cl}
\hline EPT $(\%)$ & Water quality \\
\hline $75 \%-100 \%$ & Very Good \\
$50 \%-74 \%$ & Good \\
$25 \%-49 \%$ & Average \\
$0 \%-24 \%$ & Bad \\
\hline
\end{tabular}

\section{RESULTS AND DISCUSSION}

In this study 12,362 individuals were collected, distributed into 32 families. Among these, 12,356 belong to Class Insecta, and the others to Class Crustacea (04) and Phylum Annelida (02). The number of individuals of each taxon and each sampling point is presented in Table 3 .

Rev. Ambient. Água vol. 16 n. 6, e2704 - Taubaté 2021 
Table 3. Macroinvertebrates were collected at three points of the Poxim-Açú River before (BD) and after (AD) the construction of the Jaime Umbelino de Souza Dam.

\begin{tabular}{|c|c|c|c|c|c|c|c|c|c|c|}
\hline \multirow{2}{*}{ Orders } & \multirow{2}{*}{ Families } & \multirow{2}{*}{$\frac{\text { Score }}{\text { BMWP* }}$} & \multicolumn{4}{|c|}{$\begin{array}{l}\text { Before the Dam (BD) } \\
\text { (2013) }\end{array}$} & \multicolumn{4}{|c|}{$\begin{array}{l}\text { After the Dam (AD) } \\
\text { (2015) }\end{array}$} \\
\hline & & & $\mathrm{P} 1$ & $\mathrm{P} 2$ & P3 & Total & $\mathrm{P} 1$ & $\mathrm{P} 2$ & P3 & Total \\
\hline \multirow{7}{*}{ Hemiptera } & Veliidae & 3 & 160 & 207 & 556 & 923 & 287 & 155 & 303 & 745 \\
\hline & Belostomatidae & 3 & 7 & 1 & 3 & 11 & 22 & 20 & 30 & 72 \\
\hline & Notonectidae & 3 & 0 & 1 & 0 & 1 & 5 & 10 & 7 & 22 \\
\hline & Gerridae & 3 & 27 & 8 & 35 & 70 & 42 & 24 & 41 & 107 \\
\hline & Nepidae & 3 & 0 & 2 & 0 & 2 & 8 & 1 & 5 & 14 \\
\hline & Naucoridae & 3 & 0 & 0 & 0 & 0 & 1 & 1 & 5 & 7 \\
\hline & Mesoveliidae & 3 & 0 & 0 & 0 & 0 & 0 & 0 & 5 & 5 \\
\hline \multirow{4}{*}{ Ephemeroptera } & Leptophlebiidae & 10 & 131 & 198 & 60 & 389 & 417 & 371 & 236 & 1024 \\
\hline & Leptohyphidae & 6 & 654 & 475 & 678 & 1807 & 150 & 59 & 35 & 244 \\
\hline & Baetidae & 4 & 52 & 44 & 57 & 153 & 29 & 20 & 22 & 71 \\
\hline & Caenidae & 4 & 0 & 0 & 0 & 0 & 1 & 2 & 4 & 7 \\
\hline \multirow{6}{*}{ Diptera } & Culicidae & 2 & 0 & 0 & 0 & 0 & 0 & 3 & 0 & 3 \\
\hline & Simulidae & 2 & 8 & 10 & 7 & 25 & 27 & 22 & 0 & 49 \\
\hline & Tipulidae & 4 & 1 & 1 & 1 & 3 & 4 & 6 & 3 & 13 \\
\hline & Empididae & 2 & 0 & 6 & 0 & 6 & 0 & 0 & 3 & 3 \\
\hline & Chironomidae & 2 & 224 & 82 & 36 & 342 & 27 & 47 & 29 & 103 \\
\hline & Ceratopogonidae & 2 & 0 & 0 & 0 & 0 & 0 & 1 & 0 & 1 \\
\hline \multirow{5}{*}{ Trichoptera } & Hydropsychidae & 5 & 162 & 267 & 44 & 473 & 608 & 481 & 180 & 1269 \\
\hline & Polycentropodidae & 7 & 0 & 0 & 0 & 0 & 54 & 42 & 72 & 168 \\
\hline & Philopotamidae & 8 & 0 & 0 & 0 & 0 & 402 & 592 & 227 & 1221 \\
\hline & Leptoceridae & 10 & 0 & 0 & 0 & 0 & 0 & 0 & 1 & 1 \\
\hline & Xiphocentronidae & 7 & 0 & 0 & 0 & 0 & 0 & 1 & 0 & 1 \\
\hline Megaloptera & Corydalidae & 4 & 0 & 0 & 0 & 0 & 7 & 21 & 7 & 35 \\
\hline
\end{tabular}

Continue... 


\begin{tabular}{|c|c|c|c|c|c|c|c|c|c|c|}
\hline Continued... & & & & & & & & & & \\
\hline \multirow{9}{*}{ Odonata } & Aeshnidae & 8 & 0 & 0 & 1 & 1 & 14 & 2 & 0 & 16 \\
\hline & Libellulidae & 8 & 86 & 160 & 114 & 360 & 323 & 462 & 311 & 1096 \\
\hline & Corduliidae & 8 & 0 & 0 & 0 & 0 & 7 & 0 & 7 & 14 \\
\hline & Calopterigidae & 8 & 43 & 21 & 44 & 108 & 107 & 239 & 215 & 561 \\
\hline & Dicteriadiadae & 8 & 0 & 0 & 0 & 0 & 0 & 16 & 0 & 16 \\
\hline & Megapodagrionidae & 10 & 0 & 0 & 0 & 0 & 2 & 1 & 2 & 5 \\
\hline & Perilestidae & 8 & 0 & 0 & 0 & 0 & 0 & 0 & 3 & 3 \\
\hline & Coenagrionidae & 6 & 15 & 8 & 6 & 29 & 83 & 111 & 98 & 292 \\
\hline & Gomphidae & 8 & 2 & 4 & 24 & 30 & 50 & 38 & 51 & 139 \\
\hline \multirow{5}{*}{ Coleoptera } & Gyrinidae & 3 & 0 & 0 & 0 & 0 & 68 & 92 & 75 & 235 \\
\hline & Dytiscidae & 3 & 1 & 0 & 0 & 1 & 11 & 0 & 1 & 12 \\
\hline & Crysomelidae & 3 & 0 & 0 & 0 & 0 & 0 & 1 & 0 & 1 \\
\hline & Staphilinidae & 3 & 1 & 0 & 0 & 1 & 1 & 0 & 2 & 3 \\
\hline & Elmidae & 5 & 4 & 6 & 4 & 14 & 0 & 6 & 2 & 8 \\
\hline Lepidoptera & Pyralidae & 7 & 3 & 0 & 14 & 17 & 0 & 6 & 1 & 7 \\
\hline Crustacea & Isopoda & 3 & 0 & 0 & 0 & 0 & 0 & 2 & 0 & 2 \\
\hline \multirow[t]{2}{*}{ Phylum Annelida } & Hirudinea & 1 & 0 & 0 & 0 & 0 & 1 & 0 & 0 & 1 \\
\hline & Total & - & 1581 & 1501 & 1684 & 4766 & 2758 & 2855 & 1983 & 7596 \\
\hline
\end{tabular}


Before the construction of the dam, 4,766 individuals were collected, divided mainly into five orders: Ephemeroptera (49\%), Hemiptera (21\%), Odonata (11\%), Trichoptera (10\%), and Diptera $(8 \%)$, with all the other orders representing less than $1 \%$. In the period after the construction of the dam, 7,596 individuals were collected, divided mainly into five orders: Trichoptera (35\%), Ephemeroptera (28\%), Odonata (28\%), Hemiptera (13\%), and Coleoptera (3\%), with all the other orders representing less than $2 \%$.

It is noteworthy that there was an increase in the number of Trichoptera in the period after the construction of the dam. This can be explained by the control of the river's flow, which maintained the stability of the habitats and reduced the carrying of particles and organisms (Copatti et al., 2014). This action contributes to the improvement of the BMWP biotic index due to the presence of a greater number of families (Bispo et al., 2001), but there was a reduction in the EPT index (Table 4).

Table 4. Abiotic parameters before and after the dam construction.

\begin{tabular}{|c|c|c|}
\hline \multirow{2}{*}{ Parameters } & \multicolumn{2}{|c|}{ Sampling Periods } \\
\hline & Before the dam & After the dam \\
\hline Maximum Flow Regime $\left(\mathrm{m}^{3} \mathrm{~s}^{-1}\right)$ & 6.94 & 4.71 \\
\hline Average Depth (m) & 0.34 & 0.28 \\
\hline $\mathrm{pH}$ & 7.10 & 7.70 \\
\hline Turbidity (NTU) & 43.10 & 7.68 \\
\hline Nitrate $\left(\mathrm{mg} \mathrm{L}^{-1}\right)$ & 3.02 & 0.86 \\
\hline Total Phosphorus $\left(\mathrm{mg} \mathrm{L}^{-1}\right)$ & 0.40 & 0.07 \\
\hline Chlorophyll ( $\left.\mu \mathrm{g} \mathrm{L}^{-1}\right)$ & 21.10 & 3.09 \\
\hline $\mathrm{OD}\left(\mathrm{mg} \mathrm{L}^{-1}\right)$ & 7.40 & 7.47 \\
\hline
\end{tabular}

Comparing the sampled sites and periods of macroinvertebrate collection, the greatest diversity, equitability, richness, and number of individuals were recorded after dam construction. These results can be explained by the regularization of the river, which favored the fixation of the macroinvertebrate community downstream of the dam in the Poxim-Açu River. The abiotic changes that occurred in the Poxim-Açu River in the period before and after the construction of the dam can be seen in (Table 4), there was a reduction of the maximum flow values $\left(6.94 \mathrm{~m}^{3} \mathrm{~s}^{-1}\right.$ to $\left.4.71 \mathrm{~m}^{3} \mathrm{~s}^{-1}\right)$ and the average depth reduction $(0.46 \mathrm{~m}$ to $0.34 \mathrm{~m})$. Among the water quality alterations, the turbidity was reduced (43.1 NTU to $7.68 \mathrm{NTU}$ ), as well as the nitrate $\left(3.02 \mathrm{mg} \mathrm{L}^{-1}\right.$ para $\left.0.86 \mathrm{mg} \mathrm{L}^{-1}\right)$ and the chlorophyll $\left(21.01 \mu \mathrm{g} \mathrm{L}^{-1}\right.$ to $\left.0.86 \mu \mathrm{g} \mathrm{L}^{-1}\right)$.

Flow regularization contributes to increasing the availability and variety of habitats, increasing the composition of biotic communities (Callisto et al., 2011). Studies on macroinvertebrate communities after dam construction showed shifts in the structure, biodiversity, and richness of the communities, due to changes in the type of substrate, riverflow speed and water temperature upstream of the dams (Kjaerstad et al., 2018; Phillips et al., $2015 ; 2016)$. In addition, another study showed that the construction of dams cause an increase of biomass and a reduction of macroinvertebrate taxon richness at sites upstream of the dam (Wu et al., 2019).

Galdean et al. (2000) clarify that the study of the diversity of habitats offers an opportunity for a proper assessment of the levels of anthropic impacts on river basin sites, constituting an important tool for Environmental Monitoring Programs. For a better estimation of the 
Macroinvertebrate Biodiversity parameters, the Shannon-Wiener Diversity Index (H'), the Pielou Equitability Index (J'), the EPT Index (Ephemeroptera, Plecoptera and Trichoptera), the Total Richness (S), Total Number of Individuals (n) and the Dominance (k) for each sampling site and period were calculated (Table 5).

Table 5. Shannon-Wiener Diversity (H'), Pielou Equitability (J'), EPT; Total Richness(S), Number of Individuals (n) and Dominance (k) for each Sampling Site before and after Dam Construction.

\begin{tabular}{ccccccccc}
\hline & \multicolumn{8}{c}{ Periods of Data Collection } \\
\cline { 2 - 9 } Estimators & \multicolumn{7}{c}{ Before the Dam (2013) } & \multicolumn{5}{c}{ After the Dam (2015) } \\
\cline { 2 - 9 } & Point 1 & Point 2 & Point 3 & Mean & Point 1 & Point 2 & Point 3 & Mean \\
\hline H' & 1.90 & 1.95 & 1.68 & 1.84 & 2.39 & 2.37 & 2.53 & 2.43 \\
J' & 0.66 & 0.67 & 0.59 & 0.64 & 0.72 & 0.68 & 0.74 & 0.71 \\
S & 18.00 & 18.00 & 17.00 & 17.66 & 28.00 & 32.00 & 31.00 & 30.33 \\
N & 1581.00 & 1501.00 & 1684.00 & 1588.66 & 2758.00 & 2855.00 & 1983.00 & 2.532 .00 \\
K (\%) & 0.22 & 0.18 & 0.28 & 0.22 & 0.12 & 0.13 & 0.10 & 0.11 \\
EPT (\%) & 63.18 & 65.55 & 49.82 & 59.51 & 60.22 & 54.92 & 39.18 & 51.44 \\
BMWP & 93.00 & 93.00 & 102.00 & 96.00 & 147.00 & 155.00 & 164.00 & 155.33 \\
\hline
\end{tabular}

In this study, dam construction also affected the community structure of macroinvertebrates. The Coleoptera order increased in the number of individuals, from 16 $(0.33 \%)$ before the dam construction to 259 (3.4\%) after the dam construction. The Coleoptera species are known to be generalists, exploring a diversity of habitats, and are also very tolerant to pollutants. On the other hand, there was a decrease in the number of individuals of the Orders Hemiptera from 1007 (21.12\%) to 972 (12.79\%) and Diptera from $376(7.88 \%)$ to $172(2.26 \%)$. Among the orders sensitive to disturbances and pollution, there was a reduction in the number $(2,349-49.28 \%)$ of Ephemeroptera to $1,346(17.71 \%)$; however, the Orders Trichoptera 473 (9.92\%); 2,660 (35.01\%) and Odonata $528(11.07 \%) ; 2,142(28.19 \%)$ increased in many individuals and proportions.

In addition, Vallania and Corigliano (2007) showed that the distribution of macroinvertebrate functional feeding groups was also affected after dam construction, presenting an increase in the number of filter-feeding macroinvertebrates, scrapers, and predators and a decline in the number of collectors and shredders after dam construction.

In this study, 6.828 specimens of the Ephemeroptera and Trichoptera orders were collected (55.23\% of the total of individuals collected). The order Ephemeroptera was the most abundant in the number of individuals (3.695), distributed in 4 taxons, while the order Trichoptera was represented by 3.133 individuals distributed in 5 taxons.

Among aquatic insects, these orders play an important role as bioindicators of water quality, mainly due to their great abundance in the structure of benthic communities and due to their contribution to species' diversity (Callisto et al., 2001). Taking into consideration the EPT environmental quality index, the values obtained for Points 1 and 2 allow us to classify the water quality as "Good" for both periods, with values of 63.18 and 65.55 for the period before the dam and values of 60.22 and 54.22 after the construction of the dam, while Stretch 3 presents values that classify them as "Regular".

The BMWP index presented an average score of 155 after dam construction (Table 4), classifying the water quality as "Excellent" (Class 1; >150) (Alba-Tercedor, 1996) (Table 1). This result differed from that of Oliveira (2013), before dam construction, where the water quality was classified as "Good" (Class 2; BMWP=96; Table 1). The BMWP index is qualitative, and it considers only the presence or absence of families. The greater the Family score, the greater the Family sensitivity to anthropic impacts along the river, comparing 
different degrees of environmental integrity. Some families have an exceedingly small weight in the index, which is not representative, so they are not considered for the BMWP index analysis.

\section{CONCLUSION}

The construction of the Poxim-Açu River dam affected the composition and structure of the macroinvertebrate community. After the construction, there was an increase in diversity and species richness.

The BMWP index calculated after the dam construction indicated an improvement of water quality when comparing the two periods, probably because the damming of the river and the control of its flow favored the stabilization of the macrofauna, while the EPT index indicated no change in the quality of the water.

Further research is needed to determine the long-term impacts of dam construction on biodiversity of aquatic communities, especially with a focus on the migration routes dynamics, habitats fragmentation, shifts in the river-flow rates, temperature, water quality, sediments and substrates dynamics, food availability and on other physical-chemical parameters at sites upstream and downstream of the damming.

\section{REFERENCES}

ALBA-TERCEDOR, J. Macroinvertebrados acuáticos y calidad de las aguas de los ríos. In: SIAGA, 2., 1996, Almeria. Proceedings[...] Madrid: Instituto Tecnologico Geominero de España, 1996. p. 203-213.

BAPTISTA, D. F. Uso de macroinvertebrados em procedimentos de biomonitoramento em ecossistemas aquáticos. Oecologia Brasiliensis, v. 12, n. 3. p. 425- 441, 2008.

BISPO, P. C.; OLIVEIRA, L. G.; CRISC, V. C.; SILVA, M. M. A pluviosidade como fator de alteração da entomofauna bentônica (Ephemeroptera, Plecoptera e Trichoptera) em córregos do Planalto Central do Brasil. Acta Limnologica Brasiliensia, v. 13, n. 2, p. 19, 2001.

BROOKS, A. J.; WOLFENDEN, B.; DOWNES, B. J.; LANCASTER, J. Barriers to dispersal: The effect of a weir on stream insect drift. River Research and Applications, v. 34, n. 10, p. 1244-1253, 2018. https://doi.org/10.1002/rra.3377

CALLISTO, M.; MORETTI, M.; GOULART, M. Macroinvertebrados bentônicos como ferramenta para avaliar a saúde de riachos. Revista Brasileira de Recursos Hídricos, v. 6, n. 1, p. 71-82, 2001.

CALLISTO, M.; POMPEU, P. S.; TUPINAMBÁS, T. H.; CASTRO, D. M. P.; FRANÇA, J.; SANTOS, H. A. et al. Componentes bióticos para avaliações de vazões ecológicas a jusante de barramento hidrelétrico. In: SIMPÓSIO BRASILEIRO DE RECURSOS HÍDRICOS, 19., 2011, Maceió. Anais[...]. Porto Alegre: ABRH, 2011.

CAMARGO, P. R. da S.; SOUZA, F.; BURANELLO, P. A. de A. Influência de impactos antrópicos na comunidade de macroinvertebrados na bacia do baixo Rio Grande. Maringá (PR). Revista em Agronegócio e Meio Ambiente - RAMA, v. 12, n. 2, p. 643-662, 2019. https://doi.org/10.17765/2176-9168.2019v12n2p643-662 
COPATTI, C. E.; MOREIRA, T. B.; MENZEL, C. A. Environmental quality assessment of a micro basin in southern Brazil through different approaches. Ambiência, v. 10, n. 2, p. 511-526, 2014.

DYNESIUS, M.; NILSSON, C. Fragmentation and flow regulation of river systems in the northern third of the world. Science, v. 266, p. 753-762, 1994. https://doi.org/10.1126/science.266.5186.753

GALDEAN, N.; CALliSTO, M.; BARBOSA, F. A. R. Lotic Ecosystems of Serra do Cipó, southeast Brazil: water quality and a tentative classification based on the benthic macroinvertebrate community. Aquatic Ecosystem Health and Management, v. 3, p. 545-552, 2000. https://doi.org/10.1080/14634980008650691

GONÇALVES, F. B.; MENEZES, M. S. de. Análise comparativa de índices bióticos de avaliação de qualidade de água, utilizando macroinvertebrados, em um rio litorâneo do estado do Paraná, sul do Brasil. Biota Neotropica, v. 11, n. 4, p. 27-36, 2011. https://doi.org/10.1590/S1676-06032011000400002

HAMMER, Ø. PAleontological STatistics Version 3.15. Reference manual. Oslo: Natural History Museum. University of Oslo, 2017. p. 253.

HOLT, C. R.; PFITZER, D.; SCALLEY, C.; CALDWELL, B. A.; CAPECE, P. I.; BATZER, D. P. Longitudinal variation in macroinvertebrate assemblages below a large-scale hydroelectric dam. Hydrobiologia, v. 755, p. 13-26, 2015. https://doi.org/10.1007/s10750-015-2212-6

KJAERSTAD, G.; ARNEKLEIV, J. V.; SPEED, J. D. M.; HERLAND, A. K. Effects of hydropeaking on benthic invertebrate community composition in two central Norwegian rivers. River Research and Applications, v. 34, p. 218-231, 2018. https://doi.org/10.1002/rra.3241

KRAJENBRINK, H. J.; ACREMAN, M.; DUNBAR, M. J.; HANNAH, D. M.; LAIZÉ, C. L. R.; WOOD, P. J. Macroinvertebrates community responses to river impoundment at multiple spatial scales. Science of the Total Environment, v. 650, p. 2648-2656, 2019. https://doi.org/10.1016/j.scitotenv.2018.09.264

MAGNAI, R.; NESSIMIAN, J. L.; BAPTISTA, D. F. Manual de identificação de macroinvertebrados aquáticos do Estado do Rio de Janeiro: para atividade técnica de ensino e treinamento em programas de avaliação da qualidade ecológica dos ecossistemas lóticos. Rio de Janeiro: Technical Books, 2010.

MAYNARD, C. M.; LANE, S. N. Reservoir compensation releases: impact on the macroinvertebrate community of the derwent river, Northumberland, UK-A longitudinal study. River Research and Applications, v. 28, p. 692-702, 2012. https://doi.org/10.1002/rra.2557

OLIVEIRA, A. V. Sazonalidade e estrutura da comunidade de insetos aquáticos e qualidade ambiental em um trecho do rio Poxim Açu, São Cristóvão, Sergipe. 2013. 47p. Monografia (Técnico em Agroecologia) - Instituto Federal de Sergipe, Campus São Cristóvão, 2013.

PHILLIPS, I. D.; POLLOCK, M. S.; CHIVERS, D. P. Benthic communities through the construction of a major reservoir and 40 years of change. Fundamental and Applied Limnology, v. 188, p. 279-288, 2016. https://doi.org/10.1127/fal/2016/0906 
PHILLIPS, I. D.; POLLOCK, M. S.; BOWMAN, M. F.; and CHIVERS, D. P. Thermal alteration and macroinvertebrate response below a large northern great plains reservoir. Journal of Great Lakes Research, v. 41, p. 155-163, 2015. https://doi.org/10.1016/j.jglr.2015.07.005

POMPEU, P. S.; ALVES, C. B. M.; CALLISTO, M. The effects of urbanization on biodiversity and water quality in the Rio das Velhas basin, Brazil. American Fisheries Society Symposium, v. 47, p. 11-22, 2005.

ROCHA, R. M.; LUCAS, A. A. T.; ALMEIDA, C. A. P.; MENEZES NETO, E. L.; AGUIAR NETTO, A. O. Caracterização morfométrica da sub-bacia do rio Poxim Açú, Sergipe, Brasil. Revista Ambiente e Água, v. 9, n. 2, p. 276-287, 2014. https://doi.org/10.4136/ambi-agua.1289

TONKIN, J. D.; OLDEN, J. D.; MERRITT, D. M.; REYNOLDS, L. V.; LYTLE, D. A. Flow regime alteration degrades ecological networks in riparian ecosystems. Nature Ecology \& Evolution, v. 2, p. 86-93, 2018. https://doi.org/10.1038/s41559-017-0379-0

VALLANIA, A.; CORIGLIANO, M. Del C. The effect of regulation caused by a dam on the distribution of the functional feeding groups of the benthos in the sub basin of the Grande River (san Luis, Argentina). Environmental Monitoring and Assessment, v. 124, n. 13, p. 201-209, 2007. https://doi.org/10.1007/s10661-006-9218-5

WANG, J.; DING, L. Y.; TAO, J.; DING, C. Z.; HE, D. M. The effects of dams on macroinvertebrates: global trends and insights. River Research and Applications, v. 35, p. 1-12, 2019. https://doi.org/10.1002/rra.3431

WHITE, J. C.; HANNAH, D. M.; HOUSE, A.; BEATSON, S. J. V.; MARTIN, A.; WOOD, P. J. Macroinvertebrate responses to flow and stream temperature variability across regulated and non-regulated rivers. Ecohydrology, v. 10, n. 1, p. 1-21, 2017. https://doi.org/10.1002/eco.1773

WU, H.; CHEN, J.; XU, J.; ZENG, G.; SANG, L.; LIU, Q. Effects of dam construction on biodiversity: a review. Journal of Cleaner Production, v. 221, p. 480-489, 2019. https://doi.org/10.1016/j.jclepro.2019.03.001 


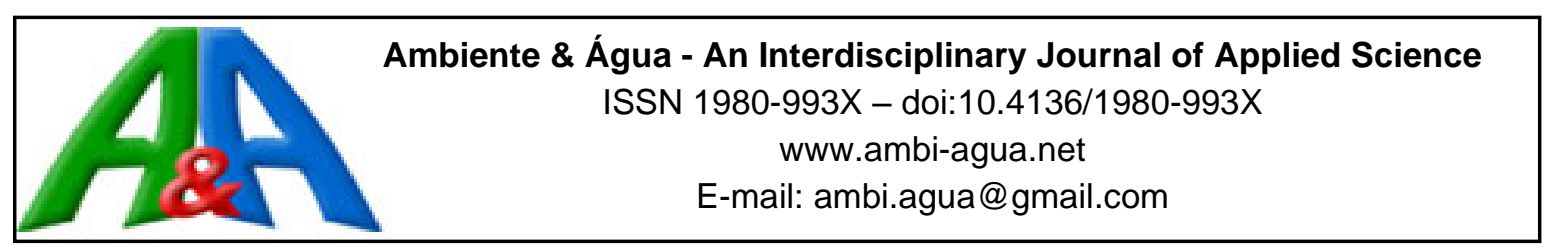

\title{
Low-cost material as active substrates for the removal of phosphorus in synthetic effluents: a proposal for social treatment technology
}

\author{
ARTICLES doi:10.4136/ambi-agua.2770
}

Received: 15 Jul. 2021; Accepted: 26 Oct. 2021

\author{
Ana Caroline da Silva Soares ${ }^{(i)}$; Liliana Pena Naval ${ }^{*}$ \\ Programa de Pós-graduação em Ciências do Ambiente. Universidade Federal do Tocantins (UFT), Quadra 109 \\ Norte, Av. NS 15, ALCNO-14, Bloco II, sala 07, Plano diretor Norte, CEP: 77001-090, Palmas, TO, Brazil. \\ E-mail: carolinesoares25@gmail.com \\ *Corresponding author. E-mail: liliana@uft.edu.br
}

\begin{abstract}
Considering the importance of the development of simplified technologies and social control in sanitation actions, this study investigated the use of laterite for phosphorus removal in synthetic effluents, through adsorption, as a low-cost alternative with the possibility of reusing the generated effluent, for communities where access to sanitation is limited. In the experimental design, the variables $\mathrm{pH}$, contact time, granulometry and laterite dosage were used. Factorial planning was used for processing, for optimization and desirability. It was observed that the removal efficiency did not have significant interference in relation to the $\mathrm{pH}$ and contact-time variables. The kinetics of the batch experiments showed that the ideal contact time was 6.4 hours and $\mathrm{pH}$ of around 4 . The adsorption capacity was plotted against equilibrium concentration for the Freundlich and Langmuir isotherms. The Langmuir isotherm was more suitable for phosphorus adsorption. The results show that laterite was effective in phosphorus adsorption in the order of removal of $87 \%$, showing itself to be a potential adsorbent material.
\end{abstract}

Keywords: laterite, phosphate adsorption, simplified effluent treatment.

\section{Material de baixo custo como substrato ativo para remoção de fósforo em efluentes sintéticos: uma proposta de tecnologia social para o tratamento}

\section{RESUMO}

Considerando a importância do desenvolvimento de tecnologias simplificadas e de controle social nas ações de saneamento, este estudo investigou a utilização da laterita para remoção de fósforo em efluentes sintéticos, por adsorção, como alternativa de baixo custo com possibilidade de reuso do efluente gerado, para comunidades onde o acesso ao saneamento é limitado. No delineamento experimental, foram utilizadas as variáveis $\mathrm{pH}$, tempo de contato, granulometria e dosagem de laterita. O planejamento fatorial foi usado para processamento, otimização e conveniência. Observou-se que a eficiência de remoção não interferiu significativamente em relação às variáveis $\mathrm{pH}$ e tempo de contato. A cinética dos experimentos em batelada mostrou que o tempo de contato ideal foi de 6,4 horas. A capacidade de adsorção foi plotada contra a concentração de equilíbrio e a isoterma de Freundlich e Langmuir. Apresentando-se a isoterma de Langmuir como a mais adequada para adsorção de fósforo. Os resultados mostram que a laterita foi eficaz na adsorção de fósforo na ordem de remoção de 
$87 \%$, mostrando-se um potencial material adsorvente.

Palavras-chave: adsorção de fosfato, laterita, tratamento simplificado de efluentes.

\section{INTRODUCTION}

The lack of sanitation services is a global problem that affects about 4.5 billion of the world population, as 663 million people worldwide still consume water from unsafe sources (UNICEF and WHO, 2015); these are located mainly in small towns, peri-urban areas, and rural areas.

Due to the low economy of scale in many of these locations, there is little interest in promoting sanitation in these areas, resulting in a precarious infrastructure from capture to distribution. This primarily impacts the most vulnerable populations, such as rural areas and regions with less political and economic power (Murtha et al., 2015). This in turn contributes to the proliferation of waterborne diseases (Ercumen, 2014; Kronenberger et al., 2011) that also primarily affect vulnerable groups (Prüss-Üstün et al., 2008; Ostro, 2004), causing injustice in terms of public policies.

Phosphorus is among the compounds present in domestic effluents that have an important impact on water bodies. It is a limiting nutrient for primary production, and for this reason it can deteriorate receiving water bodies (Pen et al., 2017; He et al., 2016; Withers et al., 2014; Choi et al., 2012;). The removal of this compound should therefore receive special attention (Jensen et al., 2015; Barca et al., 2014; Spears et al., 2013; Ismail, 2012; Jyothi et al., 2012).

Given the health importance of controlling phosphorus requirements in water, which may affect the quality of public health and the environment, regulations for human supply and surface water are presented that consider this parameter. Ordinance 888/2021 (Brasil, 2021) recommends that collective alternative water supply systems and solutions for human consumption, from surface and underground sources, must conduct an analysis of the total phosphorus parameter. Ordinance 357/2005 (Conama, 2005) establishes phosphorus limits according to the hydrodynamic conditions for each class. In lentic environments, the following concentrations of Total Phosphorus are permitted: Class $1(0.025 \mathrm{mgP} / \mathrm{L})$, Class $2(0.05$ $\mathrm{mgP} / \mathrm{L})$, Class 3 (0.15 mgP/L).

A waste management system must be environmentally effective, economically viable, and socially acceptable (McDougall et al., 2007). Inadequate infrastructure and limited management systems increase stress on resources and can lead to a water crisis in many locations (Pandey et al., 2010; 2012). As it is difficult to universalize sanitation actions, proposing simplified and low-cost systems can offer alternatives to provide opportunities for locations with little or no access to this service.

Different technologies have been used for the removal of phosphorus, such as chemical precipitation, biological treatment, and adsorption (Bashar et al., 2018; Hupfer et al., 2016; Tchobanoglous et al., 2014). Among these, adsorption has gained prominence due to the ability to remove and recover phosphorus, as well as the possibility of applying low-cost and available materials for use as active substrates (Loganathan et al., 2014; Lu et al., 2009).

A wide range of potential active filter substrates, including natural materials, were tested, such as calcium carbonate (Li et al., 2017), clay minerals (Lürling et al., 2014), dolomite, and hydroxyapatite (Boeykens et al., 2017), mesoporous materials (Huang et al., 2017), lanthanum modified zeolites (Dong et al., 2017; He et al., 2016), natural zeolite pretreated with calcium hydroxide (Gypser et al., 2018; Mitrogiannis et al., 2017), laterite and sandstone (Coulibaly et $a l ., 2016$ ), and have been reported to perform well in phosphate adsorption.

The most studied iron oxides for phosphorus adsorption are goethite and hematite, as they are abundant in oxidic soils (White and Dixon, 2002). However, laterite has also been used for phosphorus adsorption (Coulibaly et al., 2016; Huang et al., 2013; Mansing and Raut, 2013). 
Its mineralogical characteristics express its potential for use as an adsorbent. It stands out for being an effective and low-cost adsorbent with high adsorption capacity for removing organic pollutants, providing an efficient treatment (Luo et al., 2011; Zhang et al., 2010; Zhao et al., 2010). As a well-known separation process, adsorption has been widely applied to remove chemical pollutants from water. It has numerous advantages in terms of cost, flexibility and simplicity of design, operation and resistance to toxic compounds (Rafatullah et al., 2010; Ahmad et al., 2009; Zeng et al., 2007). Although the challenges in operating in sanitation are fundamentally of a technical nature, overcoming these depends not only on technological and infrastructure innovation, but also on the development of technologies that correspond to the demands and how they are manifested locally.

Alternative actions are needed to identify the vulnerability in which the community finds itself, valuing cultural conditions, contributing to the transformation of tacit knowledge into explicit, and recognizing that public participation is effective in sanitation actions. Using the knowledge acquired by experiences in a formal and non-technical language, through a technology, will be easily understood by the population that receives it. In this study, an alternative post-treatment technology of easy operation and reduced cost is presented, which can be implemented on small scales, including isolated communities and in communities where access to sanitation is limited. Therefore, this study investigated the use of laterite in natura, for the removal of phosphorus in domestic effluents, as a low cost alternative, with the possibility of reusing the effluent generated after adsorption, for communities where access to sanitation is limited or where there is difficulty in implementing conventional systems.

\section{MATERIAL AND METHODS}

\subsection{Sample collection and processing}

The material used to test phosphorus adsorption in synthetic effluent were lateritic concretions from cerrado soil. The collected material was washed in tap water to remove impurities and then dried in an oven for 24 hours at $105^{\circ} \mathrm{C}$. The samples were then ground and sieved to particle sizes of $0.150 \mathrm{~mm}, 2 \mathrm{~mm}$ and $4 \mathrm{~mm}$. The material already sieved was dried in a hot air oven at $105^{\circ} \mathrm{C}$ (Mansing and Raut, 2013). The prepared samples were subjected to physical, chemical and mineralogical analyses.

Analytical data of $\mathrm{pH}$, exchangeable bases $\left(\mathrm{SB}: \mathrm{Ca}^{2+}, \mathrm{Mg}^{2+}, \mathrm{K}^{+}\right)$, extractable acidity $\left(\mathrm{Al}^{3++} \mathrm{H}^{+}\right)$, aluminum $\left(\mathrm{Al}^{3+}\right)$ and hydrogen $\left(\mathrm{H}^{+}\right)$were used for calculating the cation exchange capacity (CEC), base saturation (V\%), aluminum saturation and the organic carbon content (Embrapa, 1997).

The methodology used to determine the organic matter content was carried out by obtaining the organic carbon wet via potassium dichromate in a sulfuric medium, followed by titration with a standard solution of ferrous ammonium sulfate - Mohr salt - Embrapa (1997). The percentage of organic matter was calculated by multiplying the carbon result by 1.724 . This factor is used because it is assumed that the participation of carbon in the average composition of humus represents 58\% (Embrapa, 1997). The $\mathrm{pH}$ was determined by the potentiometric method, according to the Manual of Sampling Procedures for Physical-Chemical Analysis of Water (Parron et al., 2011). The measurement was performed using a combined electrode immersed in soil: liquid (Potassium Chloride - $\mathrm{KCl} 1 \mathrm{M}$ ) and soil: deionized water.

All variables at level zero constitute the central points, while the combination of variables that constitute a lower level $(-1.673)$ or the highest level $(+1.673)$ constitute the axial points. For the test of optimization and desirability of the results the program, Statistic Version 7.0 was used, applying the test of desirability, this tool makes it possible to identify better conditions of adjustment of a process that makes possible the simultaneous optimization of multiple responses, providing the best conditions and the most convenient way of processing. 


\subsection{Experimental conditions}

For the adsorption tests, 3 granulometries $(0.15 \mathrm{~mm}, 2 \mathrm{~mm}, 4 \mathrm{~mm})$ were adopted (Mansing and Raut, 2013). The $\mathrm{pH}$ values and contact time studied were defined based on studies on phosphorus adsorption (Coulibaly et al., 2016; Mansing and Raut, 2013), adopting a pH range between 1.5 to 8 , contact from 2 to 18 hours. The concentration of phosphorus used in the tests was determined taking as a reference the concentration of phosphorus found in domestic effluents subjected to conventional treatments (Aslan and Kapdan, 2006).

The phosphorus solution was prepared using $\mathrm{KH}_{2} \mathrm{PO}_{4}$, adopting the final concentration of $10 \mathrm{mgP} / \mathrm{L}$. The $\mathrm{pH}$ was adjusted using $1 \mathrm{M} \mathrm{HCl}$ (hydrochloric acid) and $1 \mathrm{M} \mathrm{NaOH}$ (sodium hydroxide) solutions. The percentage of solute absorbed was obtained by Equation 1:

$R(\%)=\left(\frac{C_{0}-C_{e}}{C_{e}}\right) V$

Where: $\mathrm{R}(\%)$ is the removal rate between the initial and equilibrium concentration, $\% ; \mathrm{C}_{0}$ is the initial concentration of phosphorus, $\mathrm{mg} / \mathrm{L}$; Ce is the concentration of the solute after the time of contact with the soil in $\mathrm{mg} / \mathrm{L}$.

Adsorption is the mass of solute adsorbed per gram of soil, determined by Equation 2 .

$$
q_{e}(\%)=\left(\frac{C_{0}-C_{e}}{M s}\right) V
$$

Where: $\mathrm{q}_{\mathrm{e}}$ is the adsorption capacity, $\mathrm{mg} / \mathrm{g} ; \mathrm{C}_{0}$ is the initial concentration of phosphorus, $\mathrm{mg} / \mathrm{L}$; Ce is the concentration of the solute after the time of contact with the soil in $\mathrm{mg} / \mathrm{L}, \mathrm{V}$ is the volume of the solution used, L; Ms is the mass of soil used (kiln dried) in $\mathrm{g}$.

The adsorption isothermal curve was obtained by plotting the weight of the adsorbed solute per unit weight of the adsorbent (qe) against the balance of solute concentration (Ce). The balance isotherm data were adjusted following the Langmuir and Freundlich models (Huang et al., 2013; Kumar et al., 2010), given by Equations 3 and 4, respectively. The parameters for each model were obtained from a non-linear statistical adjustment, and the evaluation of the correlation coefficients (r2).

$$
\begin{aligned}
& q_{e}=\left(\frac{q_{0} K_{L} C_{e}}{1+K_{L} C_{e}}\right) \\
& q_{e}=K_{f} C_{e}{ }^{1 / n}
\end{aligned}
$$

Where:

qe: adsorption capacity $(\mathrm{mg} / \mathrm{g})$;

$\mathrm{q}_{0}$ : maximum adsorption capacity $(\mathrm{mg} / \mathrm{g})$;

$\mathrm{C}_{\mathrm{e}}$ : equilibrium adsorbate concentration $(\mathrm{mg} / \mathrm{L})$;

$\mathrm{K}_{\mathrm{L}}$ : constant related to the solute binding energy/adsorbent surface $(\mathrm{mg} / \mathrm{L})$;

$\mathrm{K}_{\mathrm{f}}$ : Freundlich constant (mg/g);

n: soil affinity parameter for the solute (admensional).

The effect of the phosphorus dose was studied at room temperature, using $4 \mathrm{~g}$ of dry soil in an oven, to which was added $40 \mathrm{~mL}$ of the $\mathrm{P}$ solution, prepared in a $0.01 \mathrm{M} \mathrm{CaCl}_{2}$ solution with 
concentrations of $5,10,100,150,250,400$ and $1000 \mathrm{~mL}$ of $\mathrm{P}$ in the form of $\mathrm{KH}_{2} \mathrm{PO}_{4}$. Being placed under agitation of $100 \mathrm{rpm}$, temperature $25^{\circ} \mathrm{C}$, the minimum equilibrium time was chosen for this stage, in which the changes in the concentration of the solute in the solution were equal to or less than $5 \%$ in the interval of 24 hours, as recommended by the USEPA (1992). The separation of solid/liquid phases was done through centrifugation (Digital Centrifuge DAIKI), and later filtering through a paper filter, retaining the remaining soil particles. For phosphorus determination, the single-beam spectrophotometer (HACH DR 6000) was used. All the experiments were performed on a laboratory scale.

\section{RESULTS AND DISCUSSION}

The laterite used for the development of the study presents iron and aluminum oxides (Table 1), which allow the phosphorus $(\mathrm{P})$ ions to react with the exchangeable cations and soluble ions on the internal surface of the oxides and hydroxides of $\mathrm{Fe}$ and $\mathrm{Al}$, present in the substrate (Arai and Sparks 2001; Weng et al. 2011). The availability of these elements positively influences the phosphorus adsorption process, due to the ability of interaction between them (Coulibaly et al., 2016; Huang et al., 2013; Mansing and Raut, 2013; Vilar et al., 2010).

Table 1. Physical and chemical characteristics of lateritic concretion used as an adsorbent material.

\begin{tabular}{|c|c|}
\hline Parameters & Concentration \\
\hline \multicolumn{2}{|l|}{ Physical } \\
\hline Granulometry (\%) & $\begin{array}{c}\text { Clay: } 21 \\
\text { Slime: } 19.4 \\
\text { Sand: } 59.6\end{array}$ \\
\hline \multicolumn{2}{|l|}{ Chemical } \\
\hline $\mathrm{pH}\left(\mathrm{CaCl}_{2}\right)$ & 7.30 \\
\hline Organic matter content $(\%)$ & 0.57 \\
\hline Macronutrients $\left(\mathrm{cmol}_{\mathrm{c}} / \mathrm{dm}^{3}\right)$ & $\begin{array}{c}\mathrm{Ca}: 3.86 \\
\mathrm{Mg}: 0.58 \\
\mathrm{Al}: 0.00 \\
\mathrm{H}: 1.20 \\
\mathrm{~K}: 0.23\end{array}$ \\
\hline Macronutrients $\left(\mathrm{mg} / \mathrm{dm}^{3}\right)$ & P: 10.20 \\
\hline Micronutrients (\%) & $\begin{array}{c}\mathrm{SiO}_{2}: 37.4 \\
\mathrm{Al}_{2} \mathrm{O}_{3}: 14.8 \\
\mathrm{Fe}_{2} \mathrm{O}_{3}: 35.7 \\
\mathrm{CaO}: 0.22 \\
\mathrm{MgO}: 0.13 \\
\mathrm{TiO}: 0.75 \\
\mathrm{P}_{2} \mathrm{O}_{5}: 0.16 \\
\mathrm{Na}_{2} \mathrm{O}:<0.1 \\
\mathrm{~K}_{2} \mathrm{O}: 0.18 \\
\mathrm{MnO}: 0.03\end{array}$ \\
\hline $\mathrm{CTC}\left(\mathrm{cmol}_{\mathrm{C}} / \mathrm{L}\right)$ & 5.87 \\
\hline
\end{tabular}

*Fusion with lithium tetraborate and quantification by XRF. 
The iron content $\left(35.7 \mathrm{mg} / \mathrm{dm}^{3}\right)$ found in laterite characterizes it as ferric soil (Embrapa, $2011)$, with a low organic-matter content $(0.57 \%)$, which allows for an increase in the sorption capacity of $\mathrm{P}$ on the surface of the material once the humic substances competing for the adsorption sites are few. The organic matter influences phosphorus adsorption by the formation of organomineral complexes with the constituents of the clay fraction, reducing the exposure of the adsorption surfaces (Donagemma et al., 2008). The cationic exchange capacity (CTC) of laterite was considered medium, with good adsorption capacity because it has a load of 8.78 cmolc/L (Anghinoni et al., 2013).

In order to determine the appropriate particle size for adsorption (Figure 1), the behavior of adsorption as a function of the independent variable (Figure 1a) and the desirability for adsorption (Figure 1b) were observed. The value zero (0) represents the maximum desirability, for the minimum adsorption of $25.92 \%$ and 1 represents the maximum desirability, for the maximum adsorption of $87.45 \%$.

The overall desirability was 0.8 (Figure 1c), obtained by the geometric means of all desires, being very close to 1 , which is the most desirable value. Thus, the optimization process points the $0.15 \mathrm{~mm}$ granulometry as the most satisfactory (Figure 1c) in the adsorptive process, confirming that the smallest particle sizes have a greater adsorption capacity (Fischer et al., 2019; Sekar et al., 2004).

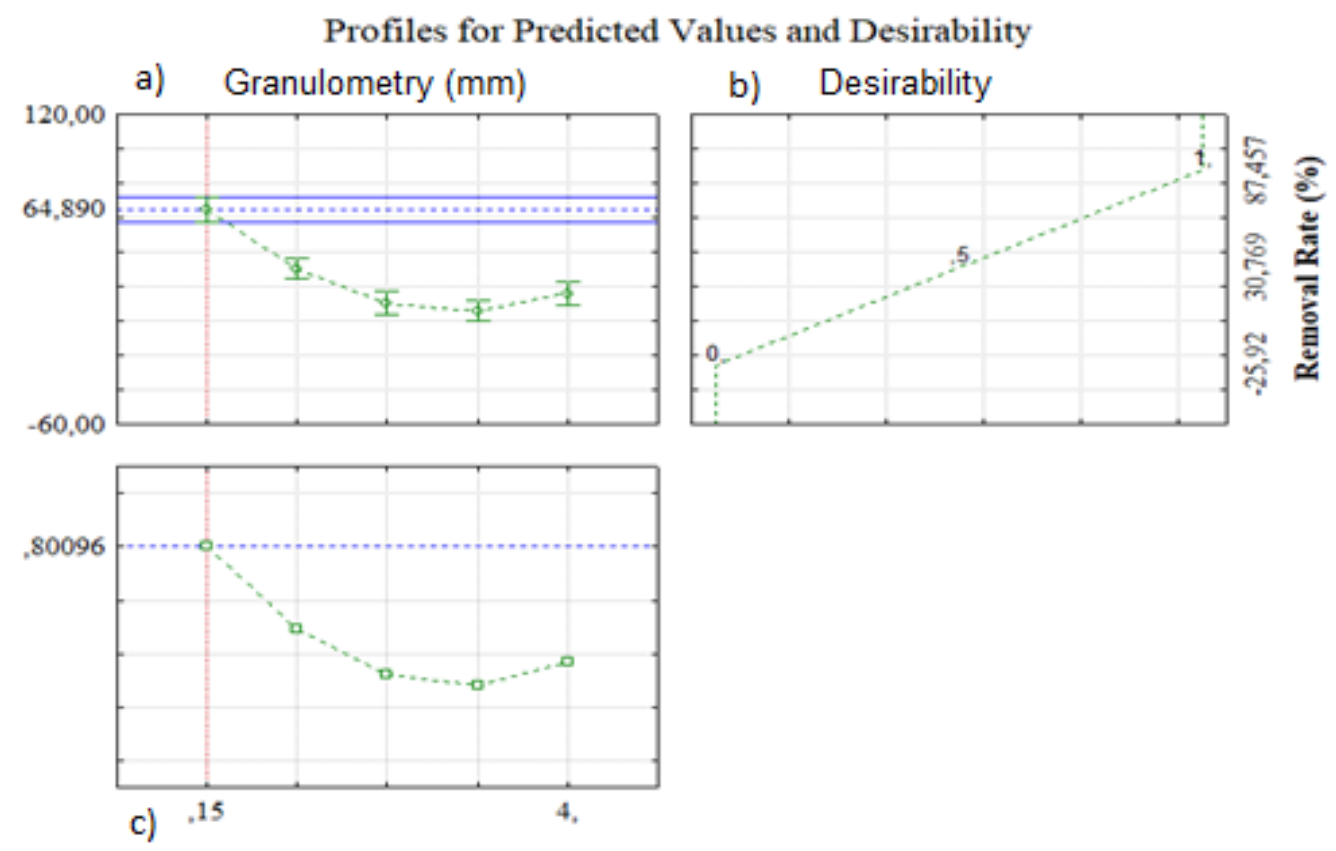

Figure 1. Profiles of predicted values and desirability for the adsorption capacity among laterites with $0.150 \mathrm{~mm}, 2 \mathrm{~mm}$ and $4 \mathrm{~mm}$ grain sizes. Adsorption as a function of the independent variable (a); desirability for adsorption (b) and the overall desirability (c).

The interactions between the independent variables for the adsorption rate response (Figure 2) demonstrated the effect of the interaction between $\mathrm{pH}$ and adsorbent dosage: the best adsorption occurred at $\mathrm{pH} 4$ (Figure 2a). The adsorptive processes tend to occur better in solutions with low pH (Coulibaly et al., 2016; Mansing and Raut, 2013; Sato and Comerford, 2005), due to its influence on the availability of aluminum and iron ions present in the laterite, to react with phosphorus, by the electronegativity of the charges on the surface of the colloids of the adsorbent material, in this case, the oxides $\left(\mathrm{Al}_{2} \mathrm{O}_{3}, \mathrm{Fe}_{2} \mathrm{O}_{3}\right)$.

A high $\mathrm{pH}$ conditions a deprotonation of the functional groups, affecting the surface load of the adsorbent (Sims and Pierzynski, 2005), decreasing the ability to exchange binders and 
decreasing the adsorption rate. In the interaction of the independent variables $\mathrm{pH}$ and contact time for the response variable, the removal rate (Figure $2 b$ ) did not show statistical significance as shown by the Pareto diagrams (Figure 3 ). The interactions of laterite dosage and contact time (Figure 2c) showed an adsorption that increased rapidly as the amount of laterite was increased, due to the greater availability of surface area. The highest adsorption occurred when the dosage was $15 \mathrm{~g}$ of laterite and a contact time of 6 hours.

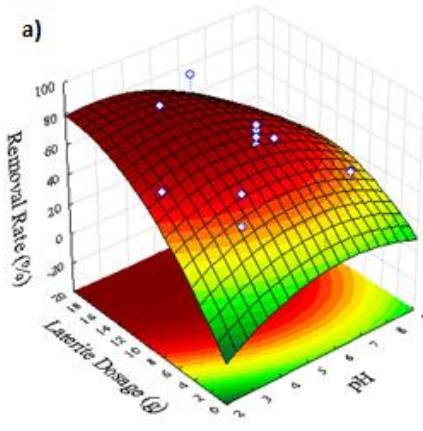

c)

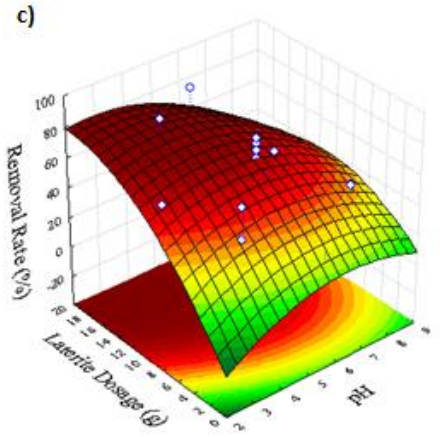

b)

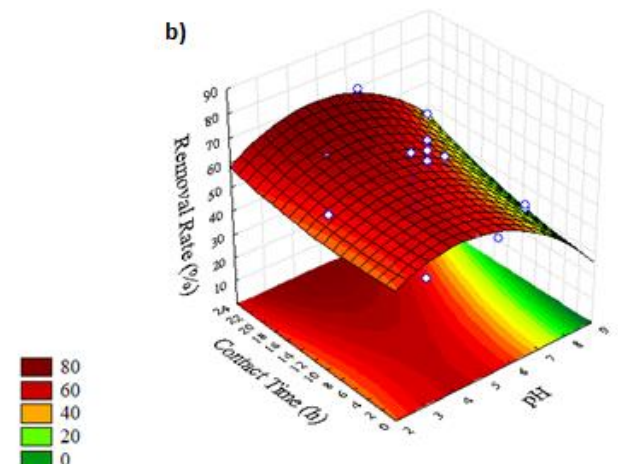

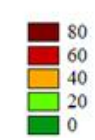

Figure 2. Response of influence of the interaction of the variables: a) dosage of adsorbent material and $\mathrm{pH}$; b) $\mathrm{pH}$ and contact time; and, c) dosage of adsorbent material and contact time in relation to the removal rate of phosphorus.

The phosphorus adsorption efficiency was dependent on the particle size of the adsorbent material, since the smaller the particle, the greater the adsorption capacity, due to the greater availability of surface area susceptible to pollutant removal (Mansing and Raut, 2013; Worch, 2012; Tchobanoglous et al., 2003). The smaller the adsorbent material particle, the greater its ability to adsorb (Fischer et al., 2019; Sekar et al., 2004).

The data from the Pareto diagrams (Figure 3) show that among the studied levels only the variable absorbent dosage had a significant effect on phosphorus removal. The laterite independent variable (Figure 3a and c), proved to be statistically significant, approaching 95\% confidence. Still, for the removal of phosphorus, the variable contact time (Figure $3 \mathrm{~b}$ ) was not statistically significant, not showing relevance in the phosphorus adsorption process.

To determine the predicted and desirable profiles and values for this adsorption process, these interactions were studied: dosage of adsorbent and $\mathrm{pH}$, contact time and dosage of adsorbent and $\mathrm{pH}$, and contact time. The best conditions for phosphorus adsorption were obtained by simultaneous optimization, in which the most satisfactory responses will occur under conditions of $\mathrm{pH} 4$, contact time of $2 \mathrm{~h}$ and dosage of $18.36 \mathrm{~g}$ of laterite. The predictions assume that by performing an adsorption with these values, the adsorption rate will reach $85.5 \%$ of phosphorus removal (Figure 4). The maximum experimental adsorption capacity occurred with a removal rate of $87.9 \%$, under the conditions of $\mathrm{pH} 5.3$, contact time $18 \mathrm{~h}$ and dosage of $15 \mathrm{~g}$ laterite. 

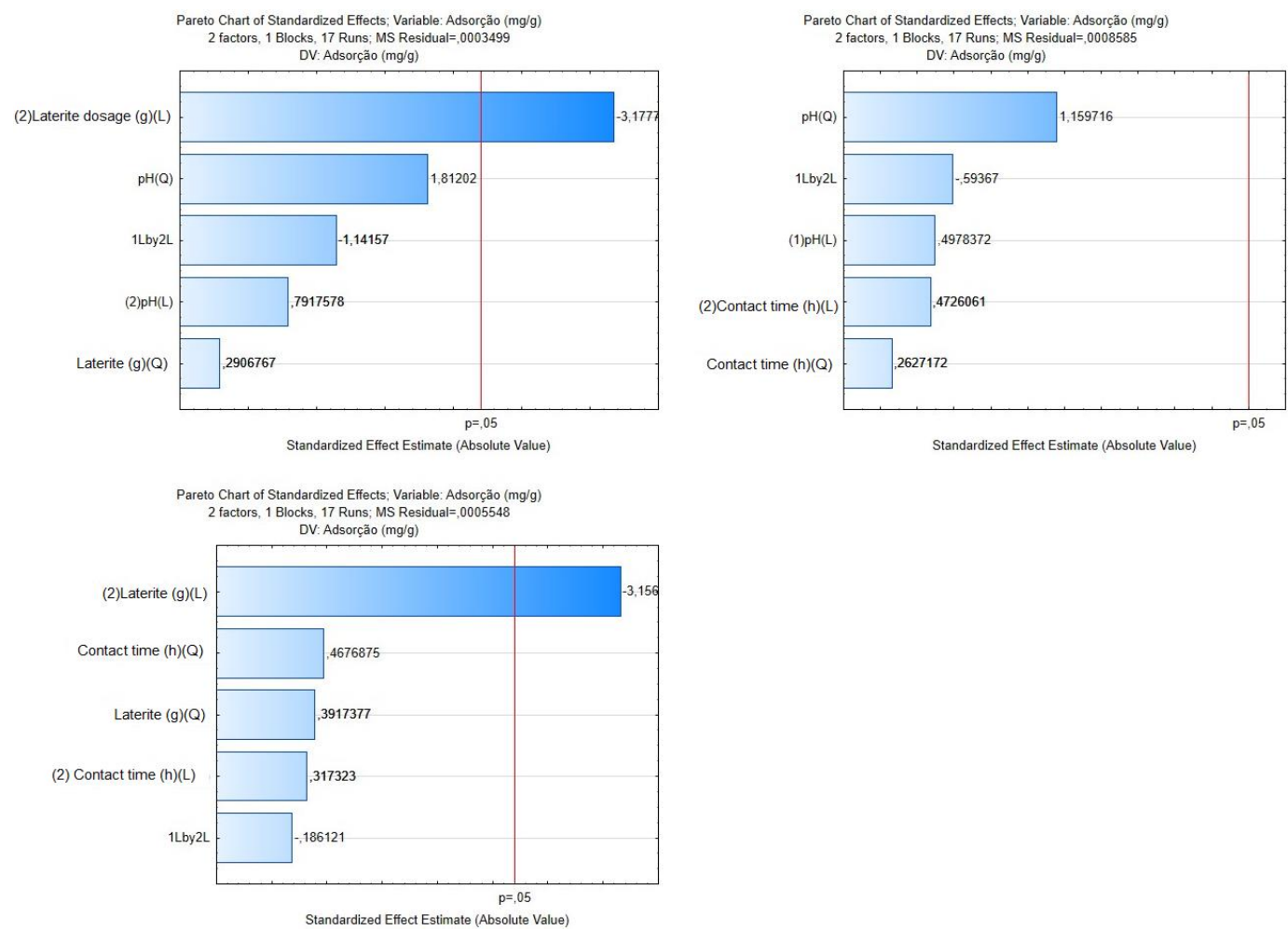

Figure 3. Pareto diagrams for the influence of the parameters: a) dosage of adsorbent and $\mathrm{pH}$; b) $\mathrm{pH}$ and contact time; and, c) dosage of adsorbent and contact time in the adsorptive process.

Profiles for Predicted Values and Desirability

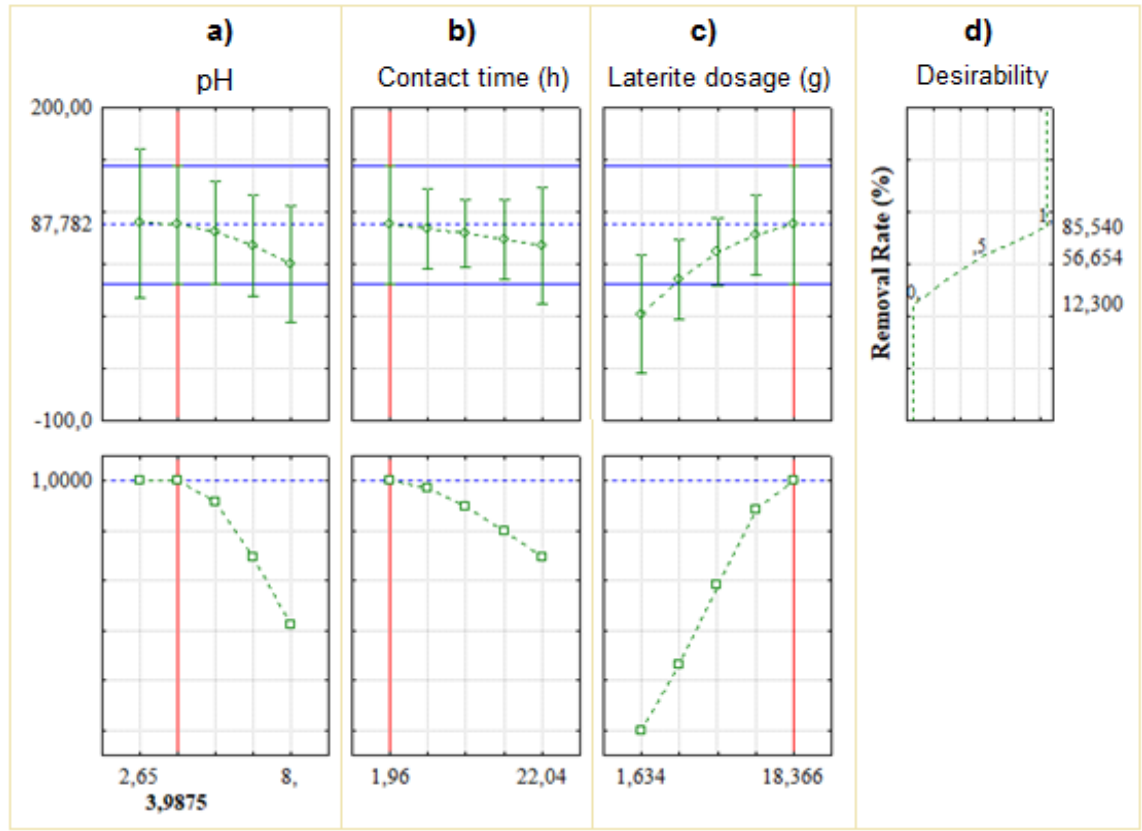

Figure 4. Predicted values for the desirability of the adsorption capacity (d) between the variables: $\mathrm{pH}$ (a), contact time (b) and dosage of adsorbent (c) in the adsorptive process.

The use of substrates rich in iron, aluminum and calcium increase the phosphate removal rate. Lateritic soils used as adsorbent material had a phosphate removal rate of $89 \%$ (Mansing and Raut (2013), 90.12\% (Huang et al., 2013) and 92.5\% (Coulibaly et al., 2016). 
Regarding the adsorption isotherms (Figure 5), a very strong correlation was observed for the Langmuir adjustment $\mathrm{r}=0.98$ (Fig. 5a) and an average correlation for the Freundlich adjustment $\mathrm{r}=0.71$ (Figure $5 \mathrm{~b}$ ). The Langmuir model provided the best fit representing phosphorus adsorption on laterite to determine the coefficient of distribution to sorption. Langmuir's model is based on the assumption that a fixed number of sites available on the surface of the adsorbent have the same energy, and the adsorption is reversible (Bohn, et al., 1979).

a)

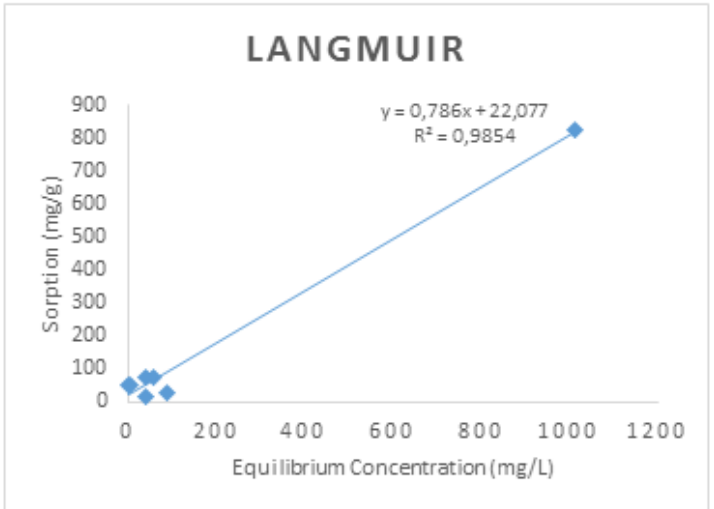

b)

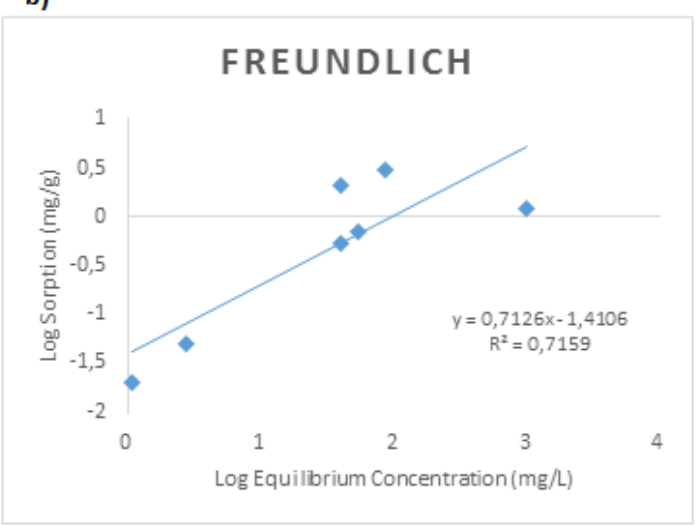

Figure 5. Phosphorus adsorption isotherm using the model of a) Langmuir and b) Freundlich.

In the Langmuir Equation, KL is the constant that presents the theoretical adsorption capacity of the monolayer and bL is the constant related to the adsorption energy. The values obtained by non-linear regression were $0.0325 \mathrm{~mL} . \mathrm{g}^{-1}$ and $0.0319 \mathrm{mg}_{\mathrm{g}} \mathrm{g}^{-1}$ (Table 2), respectively, with favorable adsorption (RL), close to linearization.

The Freundlich constants, KF and bF, are empirical constants, where $\mathrm{KF}$ and bF are related to the adsorption capacity and binding energy of the adsorbent solute-surface, respectively, obtained by non-linear regression analysis, with values of $0.00088 \mathrm{~mL} . \mathrm{g}^{-1}$ and $1.3661 \mathrm{mg} \cdot \mathrm{g}^{-1}$ (Table 2), respectively. It expresses favorable adsorption, but is easily dissociated from the phosphate ions in the aqueous solution.

Table 2. Langmuir and Freundlich constants obtained from phosphorus adsorption results.

\begin{tabular}{lllllll}
\hline Adsorbent & Langmuir & \multicolumn{5}{c}{ Freundlich } \\
\hline & $\mathrm{K}_{\mathrm{L}}\left(\mathrm{mL} \cdot \mathrm{g}^{-1}\right)$ & $\mathrm{b}_{\mathrm{L}}\left(\mathrm{mg} \cdot \mathrm{g}^{-1}\right)$ & $\mathrm{RL}$ & $\mathrm{K}_{\mathrm{F}}\left(\mathrm{mL} \cdot \mathrm{g}^{-1}\right)$ & $\mathrm{b}_{\mathrm{F}}\left(\mathrm{mg} \cdot \mathrm{g}^{-1}\right)$ & $\mathrm{n}$ \\
\hline Laterite & 0.0325 & 0.0319 & 0.99 & 0.00088 & 1.3661 & 1.36 \\
\hline
\end{tabular}

It should also be noted that, in this study, a strong correlation was obtained for the Langmuir adjustment. The Langmuir Model presented an ideal type of adsorption, which implies that the molecules are adsorbed on the surface and that the energy of the sorbed species is the same at any point, regardless of the neighboring molecules, which represents an energetically uniform surface (Kumar et al., 2008), so that the adsorbed phosphorus will be retained in a monolayer and does not have secondary adsorption sites, with a predominance of chemisorption.

The use of non-conventional and low-cost adsorbents, such as those obtained from the agricultural segments, household waste, by-products, natural materials, soil and ore, has been an alternative for wastewater treatment (Gisi et al., 2016).

The laterite used, when saturated with phosphorus, can be used as a plant fertilizer, and only the adsorption process has the potential to recover $\mathrm{P}$ as a usable fertilizer, since $\mathrm{P}$ is a non- 
renewable resource and is obtained by extraction from rocks (Sengupta and Pandit, 2011). The adsorbed phosphorus can be reused after the process of desorption, reuse or regeneration (Nguyen et al., 2014).

Technologies that recognize logical factors, including community participation, public involvement, social perception, attitudes and public acceptance can lead to improvement in practical quality and wastewater management (Saad et al., 2017).

Although there are many technologies for treating effluents, the sector still faces difficulties in implementing projects where social participation occurs, both due to the lack of initiatives on the part of local and regional governments and due to the lack of knowledge of the population on the subject, which inspires little interest in applied techniques (Rosenquist, 2005). Therefore, the use of simplified technologies will make it easier for the target community to connect with and understand these useful alternative technologies.

The use of laterite is highlighted as an alternative treatment that assists in fulfilling the needs of vulnerable populations through the management and use of technologies of lesser operational complexity (Saad et al., 2017). The effectiveness of sanitation actions depends on the collaboration and participation of individuals or the community, from the definition of the principles and guidelines of a sanitation policy to the planning and execution of these actions (Silva and Naval, 2015).

\section{CONCLUSION}

Acidic $\mathrm{pH}$ favored adsorption, influencing the availability of ions present in laterite. The adsorption of phosphorus was dependent on the particle size of the adsorbent material; the smaller the particle, the greater the adsorption. The molecules were adsorbed on the surface and retained in a monolayer, with a predominance of chemisorption.

Laterite, without chemical modifications, was tested as an adsorbent material and proved effective for the removal of phosphorus in synthetic effluents, and can be used in filtering units to remove pollutants.

It must be taken into account that urban, rural or isolated spaces are heterogeneous, made up of different communities and specificities, which requires particular forms of intervention in basic sanitation, both for environmental and educational and technological issues. Simplified techniques are evaluated as a proposal for social technology in order to meet the demand of the population without access to water treatment and distribution.

\section{ACKNOWLEDGMENTS}

The authors are grateful to financial support by CAPES (Coordenacao de Aperfeicoamento de Pesoal de Nivel Superior- Brazil) - Process PROAP/ 2017-2020 and for the master's scholarship granted by the Social Demand Program - DS (Process: 1777733).

\section{REFERENCES}

AHMAD, A.; RAFATUllaH, M.; SULAIMAN, O.; IBRAHIM, M. H.; CHII, Y. Y.; SIDDIQUE, B. M. Removal Ofcu(II) And Pb(II) Ions from Aqueous Solutions by Adsorption On Sawdust of Meranti Wood. Desalination, v. 247, p. 636-46, 2009. https://doi.org/10.1016/j.desal.2009.01.007

ANGHINONI, I.; CARMONA, F. C.; GENRO JUNIOR, S. A.; BOENI, M. Potassium fertilization in irrigated rice according to the cation exchange capacity of the soil. Brazilian Agricultural Research, v. 48, p. 1481-1488, 2013. 
https://doi.org/10.1590/S0100-204X2013001100009

ARAI, Y.; SPARKS, D. L. ATR-FTIR Spectroscopic Investigation On Phosphate Adsorption Mechanisms at The Ferrihydrite-Water Interface. Journal Colloid Interface Science, v. 241, p. 317-326, 2001. https://doi.org/10.1006/jcis.2001.7773

ASLAN, S.; KAPDAN, I. K. Batch Kinetics of Nitrogen and Phosphorus Removal from Synthetic Wastewater by Algae. Ecological Engineering, v. 28, p. 64-70, 2006. https://dx.doi.org/10.1016/j.ecoleng.2006.04.003

BARCA, C.; MEYER, D.; LIIRA, M.; DREISSEN, P.; COMEAU, Y.; ANDRÉS, Y. Chazarenc, Steel Slag Filters to Upgrade Phosphorus Removal in Small Wastewater Treatment Plants: Removal Mechanisms and Performance. Ecological Engineering, v. 68, p. 214-222, 2014. https://doi.org/10.1016/j.ecoleng.2014.03.065

BASHAR, R.; GUNGOR, K.; KARTHIKEYAN, K. G.; BARAK, P. Cost Effectiveness of Phosphorus Removal Processes in Municipal Wastewater Treatment. Chemosphere, v. 197, p. 280-290, 2018. https://doi.org/10.1016/j.chemosphere.2017.12.169

BOEYKENS, S. P.; PIOL, M. N.; LEGAL, L. S.; SARALEGUI, A. B.; VÁSQUEZ, C. Eutrophication Decrease: Phosphate Adsorption Processes In Presence of Nitrates. Journal of Environmental Management, v. 203, p. 888-895, 2017. https://doi.org/10.1016/j.jenvman.2017.05.026

BOHN, H. L.; MCNEAL, B. L.; O'CONNOR, G. A. Soil Chemistry. New York: John Wiley, 1979. $329 \mathrm{p}$.

BRASIL. Ministério da Saúde. Portaria GM/MS nº 888, de 04 de maio de 2021. Altera o Anexo XX da Portaria de Consolidação GM/MS nº 5, de 28 de setembro de 2017, para dispor sobre os procedimentos de controle e de vigilância da qualidade da água para consumo humano e seu padrão de potabilidade. Diário Oficial [da] União: seção 1, Brasília, DF, n. 85 , p. 127,07 de maio 2021.

CHOI, J.; LEE, S.; KIM, J.; PARK, K.; KIM, D.; HONG, S. Comparison of Surface Modified Adsorbents for Phosphate Removal in Water. Water, Air, \& Soil Pollution, v. 223, p. 2881-2890, 2012. https://dx.doi.org/10.1007/s11270-011-1072-6

CONAMA (Brasil). Resolução $\mathrm{n}^{\circ} 357$ de 17 de março de 2005. Dispõe sobre a classificação dos corpos de água e diretrizes ambientais para o seu enquadramento, bem como estabelece as condições e padrões de lançamento de efluentes, e dá outras providências. Diário Oficial [da] União: seção 1, Brasília, DF, n. 053, p. 58-63, 18 mar. 2005.

COULIBALY, L. S.; AKPO, S. K.; YVON, J.; COULIBALY, L. Fourier Transform Infra-Red (Ftir) Spectroscopy Investigation, Dose Effect, Kinetics And Adsorption Capacity of Phosphate From Aqueous Solution Onto Laterite And Sandstone. Journal of Environmental Management, v. 183, p. 2016. https://doi.org/10.1016/j.jenvman.2016.09.061

DONAGEMMA, G. K.; RUIZ, H. A.; ALVAREZ, V. H. V.; KER, J. C. S.; FONTES, M. P. F. Remaining Phosphorus In Clay and Silt Removed From an Oxisol after Pretreatment In Texture Analysis. Brazilian Journal of Soil Science, v. 32, p. 1785-1791, 2008. https://doi.org/10.1590/S0100-06832008000400043

DONG, S.; WANG, Y.; ZHAO, Y.; ZHOU, X.; ZHENG, H. La ${ }^{3+} \mathrm{La}(\mathrm{Oh})_{3}$ Loaded Magnetic 
Cationic Hydrogel Composites for Phosphate Removal: Effect of Lanthanum Species and

Mechanistic Study. Water Research, v. 126, p. 433-441, 2017. https://doi.org/10.1016/j.watres.2017.09.050

EMBRAPA. Centro Nacional de Pesquisa de Solos. Manual of Methods and Soil Analysis.

2. ed. Rio de Janeiro, 1997. (Documentos, 1).

EMBRAPA. Sistema brasileiro de classificação de solos. Rio de Janeiro: Embrapa Solos, 2011.

ERCUMEN, A.; GRUBER, J. S.; COLFORD, J. M. JR. Water Distribution System Deficiencies and Gastrointestinal Illness: A Systematic Review and Meta-Analysis. Environmental Health Perspective, v. 122, p. 651-60, 2014. https://doi.org/10.1289/ehp.1306912

FISCHER, H. C. V.; LIMA, L. S. D.; FELSNER, M. L.; QUINÁIA, S. P. Study of the adsorption capacity of commercial activated carbon versus storage time. Forest Science, v. 29, p. 1090-1099, 2019. https://doi.org/10.5902/1980509838092

GISI, S.; LOFRANO G.; GRASSI, M.; NOTARNICOLA, M. Characteristics and Adsorption Capacities of Low-Cost Sorbents for Wastewater Treatment: A Review. Sustainable $\begin{array}{llllll}\text { Materials and Technologies, } & \text { v. } & \text { 9, } & \text { p. 10-40, }\end{array}$ https://doi.org/10.1016/j.susmat.2016.06.002

GYPSER, S.; HIRSCH, F.; SCHLEICHER, A. M.; FREESE, D. Impact of Crystalline and Amorphous Iron- and Aluminum Hydroxides on Mechanisms of Phosphate Adsorption and Desorption. Journal Environmental Sciences, v. 70, p. 175-189, 2018. https://doi.org/10.1016/j.jes.2017.12.001

HE, Y.; LIN, H.; DONG, Y.; LIU, Q.; WANG, L. Simultaneous Removal of Ammonium and Phosphate By Alkaline Activated and Lanthanum-Impregnated Zeolite. Chemosphere, v. 164, p. 387-395, 2016. https://dx.doi.org/10.1016/j.chemosphere.2016.08.110

HUANG, W.; ZHANG Y.; LI, D. Adsorptive Removal of Phosphate From Water Using Mesoporous Materials: A Review. Journal of Environmental Management, v. 193, p. 1 -13, 2017. https://doi.org/10.1016/j.jenvman.2017.02.030

HUANG, W.Y.; ZHU, R.-H.; HE, F.; LI, D.; ZHU, Y.; ZHANG, Y. M. Enhanced Phosphate Removal from Aqueous Solution By Ferric-Modified Laterites: Equilibrium, Kinetics And Thermodynamic Studies. Chemical Engineering Journal, v. 228, p. 679-687, 2013. https://doi.org/10.1016/j.cej.2013.05.036

HUPFER, M.; REITZEL, K.; KLEEBERG, A.; LEWANDOWSKI, J. Long-Term Efficiency of Lake Restoration by Chemical Phosphorus Precipitation: Scenario Analysis with A Phosphorus Balance Model. Water Research, v. 97, p. 153-161, 2016. https://doi.org/10.1016/j.watres.2015.06.052

ISMAIL, Z. Z. Kinetic Study for Phosphate Removal from Water by Recycled Date-Palm Wastes as Agricultural By-Products. International Journal of Environmental Studies, v. 69, p. 135-149, 2012. https://doi.org/10.1080/00207233.2012.656975

JENSEN, H. S.; REITZEL, K.; EGEMOSE, S. Evaluation of Aluminum Treatment EffiCiency on Water Quality and Internal Phosphorus Cycling in Six Danish Lakes. Hydrobiologia, v. 751, p. 189-199, 2015. https://doi.org/10.1007/s10750-015-2186-4 
JYOTHI, M. D.; KIRAN, R. K.; RAVINDHRANATH, K. Phosphate Pollution Control in Waste Waters Using New Bio-Sorbents. Water Resources and Environmental Engineering, v. 4, p. 73-85, 2012. https://doi.org/10.5897/IJWREE11.132

KRONENBERGER, D. M. P.; PEREIRA, R. S.; FREITAS, E. A. V.; SCARCELLO, J. A.; CLEVERÁRIO JUNIOR, J. Sanitation and Environment. In: IBGE. Atlas of Sanitation 2011. Rio de Janeiro, 2011. Cap. 3. Available at: https://biblioteca.ibge.gov.br/visualizacao/livros/liv53096_cap3.pdf Access: Oct. 2021.

KUMAR, K. V.; PORKODI, K.; ROCHA, F. Isotherms and Thermodynamics by Linear and Nonlinear Regression Analysis for Methylene Blue Sorption on Activated Carbon: Comparison of Various Error Functions. Journal of Hazardous Materials, v. 151, p. 794-804, 2008. https://dx.doi.org/10.1016/j.jhazmat.2007.06.056

KUMAR, P.; SUDHA, S.; SRIVASTAVA, V. C. Phosphate Removal from Aqueous Solution Using Coir-Pith Activated Carbon. Separation Science and Technology, v. 45, p. 14631470, 2010. https://dx.doi.org/10.1080/01496395.2010.485604

LI, Z.; SUN, X.; HUANG, L.; LIU, D.; YU, L.; WU, H. et al. Phosphate Adsorption and Precipitation On Calcite Under Calco-Carbonic Equilibrium Condition. Chemosphere, v. 183, p. 419-428, 2017. https://doi.org/10.1016/j.chemosphere.2017.05.139

LOGANATHAN, P.; VIGNESWARAN, S.; KANDASAMY, J.; BOLAN, N. S. Recovery of Water Phosphate Using Sorption. Critical Reviews in Environmental Science and Technology, v. 44, p. 847-907, 2014. https://dx.doi.org/10.1080/10643389.2012.741311

LU, S. G.; BAI, S. Q.; ZHU, L.; SHAN, H. D. Fly Ash Aqueous Solution Phosphate Removal Mechanism. Journal of Hazardous Materials, v. 161, p. 95-101, 2009. https://dx.doi.org/10.1016/j.jhazmat.2008.02.123

LUO, L. H.; FENG, Q. M.; WANG, W. Q.; ZHANG, B. L. Fe $\mathrm{O}_{4} /$ Rectorite Composite: Preparation, Characterization and Absorption Properties from Contaminant Contained in Aqueous Solution. Advanced Materials Research, v. 287-290, p. 592-598, 2011. https://doi.org/10.4028/www.scientific.net/AMR.287-290.592

LÜRLING, M.; WAAJEN, G.; VAN OOSTERHOUT, F. Humic Substances Interfere With Phosphate Removal By Lanthanum Modified Clay in Controlling Eutrophication. Water Research, v. 54, p. 78-88, 2014. https://doi.org/10.1016/j.watres.2014.01.059

MANSING, P.; RAUT, P. D. Removal of Phosphorus from Sewage Effluents by Adsorption on Laterite. International Journal of Engineering Research \& Technology, v. 2, n. 9, 2013.

MCDOUGALL, F.; WHITE, P.; FRANKE, M.; HINDLE, P. Integrated Solid Waste Management, A Life Cycle Inventory. $2^{\text {nd }}$ ed. United Kingdom: Blackwell Publishing, 2007.

MITROGIANNIS, D.; PSYCHOYOU, M.; BAZIOTIS, I; INGLEZAKIS, V. J. Removal of Phosphate from Aqueous Solutions by Adsorption onto $\mathrm{Ca}(\mathrm{OH})_{2}$ Treated Natural Clinoptilolite. Chemical Engineering Journal, v. 320, p. 510-522, 2017. https://doi.org/10.1016/j.cej.2017.03.063

MURTHA, N. A.; CASTRO, J. E; HELlER, L. A Historical Perspective of the First Public Policies on Sanitation and Water Resources in Brazil. Environment \& Society, v. 18, p. 193-210, 2015. https://doi.org/10.1590/1809-4422ASOC1047V1832015

NGUYEN, T. A. H.; NGO, H. H.; GUO, W. S.; ZHOU, J. L.; WANG, J.; LIANG, H. et al. 
Elimination of Phosphorus from the Aqueous Solution Using Okara Loaded With

Zirconium as a Biosorbent. Bioresource Technology, v. 170, p. 30-37, 2014. https://doi.org/10.1016/j.biortech.2014.07.069

OSTRO, B. Outdoor Air Pollution: Assessing the Environmental Burden of Disease at National and Local Levels. Geneva: WHO, 2004. (Environmental Burden of Disease Series, 5).

PANDEY, V. P.; BABEL, M. S.; SHRESTHA, S.; KAZAMA, F. Vulnerability of Freshwater Resources in Large and Medium Nepalese River Basins to Environmental Change. Water Science Technology, v. 61, p. 1525-1534, 2010. https://doi.org/10.2166/wst.2010.751

PANDEY, V. P.; SHRESTHA, S.; KAZAMA, F. Groundwater in the Kathmandu Valley: Development Dynamics, Consequences and Prospects for Sustainable Management. Europe Water, v. 37, p. 3-14, 2012.

PARRON, L. M.; MUNIZ, H. DE F.; PEREIRA, C. M. Manual of Sampling Procedures for Physical-Chemical Analysis of Water. Colombo, PR: Embrapa Florestas, 2011. (Documentos, 232).

PEN, C.; CHAGAS, I.; KLIMESKI, A.; LYNGSIE, G. A Review of Phosphorus Removal Structures: How to Assess and Compare their Performance. Water, v. 9, p. 583, 2017. https://doi.org/10.3390/w9080583

PRÜSS-ÜSTÜN, A.; BOS, R.; GORE, F.; BARTRAM, J. Safer Water, Better Health: Costs, Benefits and Sustainability of Interventions to Protect and Promote Health. Geneva: WHO, 2008.

RAFATULLA, H. M.; SULAIMAN, O.; HASHIM. R.; AHMAD, A. Adsorption of Methylene Blue on Low-Cost Adsorbents: A Review. Journal of Hazardous Materials, v. 177, p. 70-80, 2010. https://doi.org/10.1016/j.jhazmat.2009.12.047

ROSENQUIST, L. E. D. A psychosocial analysis of the human-sanitation nexus. Journal of Environmental psychology, v. 25, n. 3, p. 335-346, 2005. https://doi.org/10.1016/j.jenvp.2005.07.003

SAAD, D.; BYRNE, D.; DRECHSEL, P. Social Perspectives on the Effective Management of Wastewater. In: FAROOQ, R.; AHMAD, Z. (eds.). Physico-Chemical Wastewater Treatment and Resource Recovery. Rijeka: InTech, 2017. https://dx.doi.org/10.5772q67312

SATO, S.; COMERFORD, N. B. Influence of Soil Ph on Phosphorus Adsorption and Desorption in a Brazilian Wet Ultisol. Brazilian Journal of Soil Science, v. 29, p. 685 694, 2005. https://doi.org/10.1590/S0100-06832005000500004

SEKAR, M.; SAKTHI, V.; RENGARAJ, S. Kinetics and Equilibrium Adsorption Study of Lead (Ii) Onto Activated Carbon Prepared from Coconut Shell. Colloid and Interface Science, v. 279, p. 307-313, 2004. https://doi.org/10.1016/j.jcis.2004.06.042

SILVA, F. A. C.; NAVAL, L. P. Contribuições para a construção de estratégias de suporte ao controle social. Ambiente \& Sociedade. v. 18, n. 1, p. 65-80, 2015. https://doi.org/10.1590/1809-4422ASOC593V1812015en

SENGUPTA, S.; PANDIT, A. Selective Removal of Phosphorus from Wastewater Combined with Its Recovery as a Solid-Phase Fertilizer. Water Research, v. 45, p. 3318-3330, 2011. https://dx.doi.org/10.1016/j.watres.2011.03.044 
SIMS, J. T.; PIERZYNSKI, G. M. Chemistry of Phosphorus in Soils. In: TABATABAI, M. A.; SPARKS, D. L. Chemical Processes in Soils. Madison: Soil Science Society of America, 2005. p. 151-192.

SPEARS, B. M.; DUDLEY, B.; REITZEL, K.; RYDIN, E. Geo-Engineering in Lakes: A Call for Consensus. Environmental Science Technology, v. 47, p. 3953-3954, 2013. https://doi.org/10.1021/es401363w

TCHOBANOGLOUS, G. et al. Wastewater Engineering: Treatment and Resource Recovery. New York: Mcgraw-Hill Education, 2014.

TCHOBANOGLOUS, G.; BURTON, F. L.; STENSEL, H. D. Adsorption. In: METCALF \& EDDY (ed.). Wastewater Engineering: Treatment and Reuse. $4^{\text {th }}$ ed. New York: Mcgraw-Hill, 2003. p. 1138-1162.

UNICEF; WHO. Progress On Sanitation and Drinking Water. Geneva, 2015.

USEPA. Batch-Type Procedures for Estimating Soil Adsorption of Chemicals. Epa530/Sw-87-006-F. Washington, D.C., 1992.

VILAR, C. C.; COSTA, A. C. S. D.; HOEPERS, A.; SOUZA JUNIOR, I. G. D. Maximum Phosphorus Adsorption Capacity Related to Iron and Aluminum Forms In Subtropical Soils. Brazilian Journal of Soil Science, v. 34, p. 1059-1068, 2010. https://doi.org/10.1590/S0100-06832010000400006

WENG L.; VEGA F. A.; VAN RIEMSDIJK W. H. Competitive and Synergistic Effects in pH Dependent Phosphate Adsorption in Soils: Lcd Modeling. Environmental Science Technology, v. 45, p. 8420-8428, 2011. https://doi.org/10.1021/es201844d

WHITE, G. N.; DIXON, J. B. Kaolin-Serpentine Minerals. In: AMONETTE, J. E.; BLEAM, W. F.; SCHULZE, D. G.; DIXON, J. B. (eds.). Soil Mineralogy with Environmental Applications. Madison: Soil Science Society of America, 2002. p. 389-414.

WITHERS, P. J. A., SYLVESTER-BRADLEY, R.; JONES, D. L.; HEALEY, J. R.; TALBOYS, P. J. Feed the Crop not the Soil: Rethinking Phosphorus Management in the Food Chain. Environmental Science \& Technology, v. 48, p. 6523-6530, 2014. https://doi.org/10.1021/es501670j

WORCH, E. Adsorption Technologies in Water Treatment. Fundamentals, Processes and Modelling. Berlin; Boston: The Gruyter, 2012.

ZENG, G. M.; HUANG D. L.; HUANG, G. H.; HU T. J.; JIANG, X. Y.; FENG, C. L. Composting of Lead-Contaminated Solid Waste with Inocula of White-Rot Fungus. $\begin{array}{llllll}\text { Bioresource Technology, v. 98, p. } & \text { 320-326, }\end{array}$ https://doi.org/10.1016/j.biortech.2006.01.001

ZHANG, S. X.; NIU, H. Y.; HU, Z. I.; CAI, Y. Q.; SHI Y. L. Preparation of Carbon Coated $\mathrm{Fe}_{3} \mathrm{O}_{4}$ nanoparticle sand their Application for Solid-Phase Extraction of Polycyclic Aromatic Hydrocarbons from Environmental Water Samples. Journal $\begin{array}{llllll}\text { Chromatography, } & \text { v. } & 1217, & \text { p. } & 4757-64, & 2010 .\end{array}$ https://doi.org/10.1016/j.chroma.2010.05.035

ZHAO, X. L.; WANG, J. M.; WU, F. C.; WANG, T.; CAI, Y. Q.; SHI, Y. L. Removal of fluoride from Aqueous media by $\mathrm{Fe}_{3} \mathrm{O}_{4}-\mathrm{Al}(\mathrm{OH})_{3}$ magnetic Nanoparticles. Journal Hazard Mater, v. 173, p. 102-109, 2010. https://doi.org/10.1016/j.jhazmat.2009.08.054 


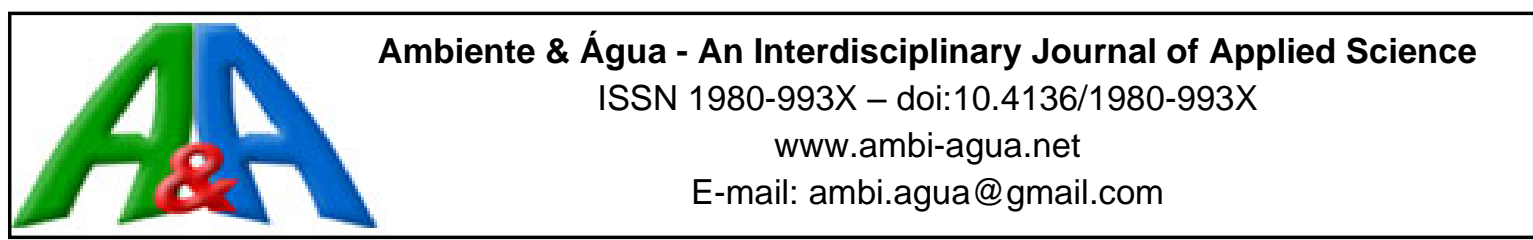

\title{
Saline waters and nitrogen/potassium fertilization combinations on physiological aspects and production of West Indian cherry
}

\author{
ARTICLES doi:10.4136/ambi-agua.2780
}

Received: 11 Aug. 2021; Accepted: 26 Oct. 2021

\section{Evandro Manoel da Silva ${ }^{1^{*} \text {; }}$; Hans Raj Gheyi ${ }^{1}$; Reginaldo Gomes Nobre $^{2}$ (D); Geovani Soares de Lima ${ }^{1}$; ; Lauriane Almeida dos Anjos Soares ${ }^{3}$; Benedito Ferreira Bonifácio 1 (ic}

\footnotetext{
${ }^{1}$ Programa de Pós-Graduação em Engenharia Agrícola. Universidade Federal de Campina Grande (UFCG), Avenida Aprígio Veloso, n ${ }^{\circ} 882$, CEP: 58429-140, Campina Grande, PB, Brazil.

E-mail: hans@pq.cnpq.br, geovanisoareslima@gmail.com, benedito_agronomo@hotmail.com

${ }^{2}$ Departamento de Ciência e Tecnologia. Universidade Federal Rural do Semi-Árido (UFERSA), Sítio Esperança II, Zona rural, CEP: 59780-000, Caraúbas, RN, Brazil. E-mail: rgomesnobre@ yahoo.com.br

${ }^{3}$ Unidade Acadêmica de Ciências Agrárias. Universidade Federal de Campina Grande (UFCG), Rua Jario Vieira Feitosa, n 1770, CEP: 58840-000, Pombal, PB, Brazil. E-mail: lauriane.soares@pq.cnpq.br

*Corresponding author. E-mail: evandroagroman@ hotmail.com
}

\begin{abstract}
This study evaluated the influence of combinations of nitrogen and potassium doses on the physiology and fruit production of West Indian cherry irrigated with waters of different salinities in the second year of cultivation. The experiment was conducted in the municipality of Pombal-PB, Brazil, in plastic containers adapted as lysimeters installed in the field, in a randomized block design, $5 \times 4$ factorial scheme corresponding to five levels of electrical conductivity of irrigation water (ECw): $0.3,1.3,2.3,3.3$ and $4.3 \mathrm{dS} \mathrm{m}^{-1}$, and four combinations of nitrogen and potassium fertilization: $70 \% \mathrm{~N}+50 \% \mathrm{~K}_{2} \mathrm{O} ; 100 \% \mathrm{~N}+75 \% \mathrm{~K}_{2} \mathrm{O} ; 130 \% \mathrm{~N}+$ $100 \% \mathrm{~K}_{2} \mathrm{O}$ and $160 \% \mathrm{~N}+125 \% \mathrm{~K}_{2} \mathrm{O}$ of the dose recommended for West Indian cherry, with three replicates and one plant per plot. The cv. 'Flor Branca' was grafted on the cv. 'Junco', between 420 and 550 days after transplanting. Nitrogen and potassium combinations did not mitigate the deleterious effects of water salinity on the physiology and fruit formation of West Indian cherry. An increase in ECw intensifies the intercellular electrolyte leakage and reduces the water potential in the branch, chlorophyll content in the leaves, $\mathrm{CO}_{2}$ assimilation rate, equatorial and polar diameters as well as the mass of fruits. Fertilization of plants with $70 \% \mathrm{~N}$ $+50 \%$ of $\mathrm{K}_{2} \mathrm{O}$, compared to the other fertilization combinations, causes less intercellular electrolyte leakage and promotes higher $\mathrm{CO}_{2}$ assimilation rates, higher chlorophyll content in leaves, and fruits of larger size and mass.
\end{abstract}

Keywords: Malpighia emarginata D. C, mineral fertilization, salt stress.

\section{Águas salinas e combinações de adubação com nitrogênio/potássio sobre aspectos fisiológicos e produção de aceroleira}

\section{RESUMO}

O objetivo do trabalho foi avaliar a influência de combinações de doses de nitrogênio e potássio sobre a fisiologia e a produção de frutos de aceroleira irrigada com água de diferentes

This is an Open Access article distributed under the terms of the Creative Commons Attribution License, which permits unrestricted use, distribution, and reproduction in any medium, provided the original work is properly cited. 
salinidades, no segundo ano de cultivo. O experimento foi conduzido no município de Pombal$\mathrm{PB}$, Brasil, em recipientes plásticos adaptados como lisímetros instalados em campo, em delineamento de blocos ao acaso, esquema fatorial 5 x 4 referentes a cinco níveis de condutividades elétricas da água de irrigação (CEa): 0,$3 ; 1,3 ; 2,3 ; 3,3$ e 4,3 dS m m $^{-1}$ e quatro combinações de adubação nitrogenada e potássica: $70 \% \mathrm{~N}+50 \% \mathrm{~K}_{2} \mathrm{O} ; 100 \% \mathrm{~N}+75 \% \mathrm{~K}_{2} \mathrm{O}$; $130 \% \mathrm{~N}+100 \% \mathrm{~K}_{2} \mathrm{O}$ e $160 \% \mathrm{~N}+125 \% \mathrm{~K}_{2} \mathrm{O}$ da dose recomendada para aceroleira, com três repetições e uma planta por parcela. Estudou-se a cv. Flor Branca enxertada sobre a cv. Junco, entre 420 e 550 dias após o transplantio. As combinações de nitrogênio e potássio não mitigam os efeitos deletérios da salinidade da água sobre a fisiologia e a produção de frutos da aceroleira. $\mathrm{O}$ aumento na $\mathrm{CEa}$ intensifica os danos às membranas celulares, reduz o potencial hídrico no ramo, teor de clorofila nas folhas, taxa de assimilação de $\mathrm{CO}_{2}$, diâmetro equatorial e polar e a massa de frutos. A adubação das plantas com $70 \%$ de $\mathrm{N}+50 \%$ de $\mathrm{K}_{2} \mathrm{O}$, em relação às outras combinações de adubação, causa menor extravasamento de eletrólitos e proporciona maior taxa de assimilação de $\mathrm{CO}_{2}$, teor de clorofila nas folhas, frutos de maior tamanho e massa.

Palavras-chave: estresse salino, fertilização mineral, Malpighia emarginata D. C.

\section{INTRODUCTION}

West Indian cherry (Malpighia emarginata D.C.) is one of the promising species in the fruit sector in the semi-arid region of Northeastern Brazil. It can be consumed fresh or processed, in the form of juices, ice cream, jams, syrups, liqueurs, fruit preserves, etc., standing out for the nutritional value of its fruits, mainly as a source of vitamin $\mathrm{C}$, anthocyanins, iron, calcium, vitamin A and B complex vitamins, resulting in great demand in the export market (Esashika et al., 2013).

Due to the adaptation to edaphoclimatic conditions, about $78 \%$ of West Indian cherry production in Brazil is concentrated in the Northeast region, and its main producers are the states of Pernambuco, Ceará, Sergipe, Paraíba and Piauí (Ibge, 2017). However, the reduction of water volume in water sources and the high concentration of salts in irrigation water may become limiting factors for the exploitation of this crop in the semi-arid region of Northeastern Brazil (Lima et al., 2019a).

In this region, salt stress stands out among the abiotic stresses that most hamper the growth and production of agricultural species (Carneiro et al., 2002), due to the reduction in the osmotic potential of the soil solution and the occurrence of nutritional imbalance and physiological disorders through metabolic alterations such as oxidative stress (Mendes et al., 2011), caused by the effect of the high concentration of toxic ions, especially $\mathrm{Na}^{+}$and $\mathrm{Cl}^{-}$, in the protoplasm (Flowers et al., 2014), which also promote structural changes and rupture of cell membranes (Ferraz et al., 2015).

Studies investigating the effect of irrigation water salinity between 0.6 and $3.8 \mathrm{dS} \mathrm{m}^{-1}$ has shown harmful effects of salt stress on photosynthesis, photochemical efficiency, water relations, growth, and production components of West Indian cherry (Sá et al., 2018a; 2018b; 2019; Lima et al., 2019a). Some studies have shown that the increase in potassium doses mitigated the deleterious effect of salt stress on plant growth, the number of fruits and total weight of fruits per plant (Lima et al., 2019b) and of nitrogen and phosphorus proportions on photochemical efficiency and growth (Sá et al., 2018a), photosynthetic pigments (Sá et al., 2018b), and the number of fruits per plant (Sá et al., 2019).

These positive effects may be related to the decrease in $\mathrm{Na}^{+} / \mathrm{K}^{+}$and $\mathrm{Cl}^{-} / \mathrm{NO}_{3}{ }^{-}$ionic ratios in plant tissues as a function of increased $\mathrm{N}$ and $\mathrm{K}$ doses, hence offsetting the effects of nutritional imbalance and salt stress on physiological aspects, growth, and production of plants (Andrade Junior et al., 2011). Moreover, an adequate concentration of $\mathrm{N}$ in plant tissue may contribute to a greater synthesis of low-molecular-weight compounds, such as glycine betaine 
and proline, which act as membrane osmoprotectants and macromolecules, and may aid in the osmotic adjustment of plants to salinity (Ashraf et al., 2018). On the other hand, K can minimize the effects of salinity by promoting the control of cell turgor, regulation of stomatal conductance, activation of enzymes, and translocation of carbohydrates in plants (Almeida et al., 2017; Hasanuzzaman et al., 2018).

Based on these hypotheses and on the need for utilization of saline water in the cultivation of fruit crops and fertilization management strategies to mitigate the negative effects of salinity, this study evaluated the effect of combinations of nitrogen and potassium doses on the physiology and fruit production of West Indian cherry irrigated with waters of different salinities, in the second year of cultivation.

\section{MATERIAL AND METHODS}

The experiment was carried out in the field using 60-L containers adapted as lysimeters, installed in an experimental area belonging to the Center of Sciences and Agri-food Technology of the Federal University of Campina Grande, in the municipality of Pombal, PB, Brazil. The reference geographic coordinates of the site are $6^{\circ} 48^{\prime} 16^{\prime \prime}$ South latitude, 37 $49^{\prime} 15^{\prime \prime}$ West longitude, and mean altitude of $144 \mathrm{~m}$. According to the Köppen-Geiger classification, adapted to Brazil, the climate of the region is classified as BSh, hot semi-arid, whose precipitation, mean temperature, and relative air humidity during the experimental period were $8.0 \mathrm{~mm}, 27.7^{\circ} \mathrm{C}$, and $44.8 \%$, respectively (Inmet, 2018).

The treatments were distributed in randomized blocks, with three replicates, in a $5 \times 4$ factorial scheme, corresponding to five salinity levels of irrigation water $(0.3 ; 1.3 ; 2.3 ; 3.3$ and $\left.4.3 \mathrm{dS} \mathrm{m}^{-1}\right)$ and four combinations of nitrogen and potassium doses $\left(\mathrm{C} 1=70 \% \mathrm{~N}+50 \% \mathrm{~K}_{2} \mathrm{O}\right.$; $\mathrm{C} 2=100 \% \mathrm{~N}+75 \% \mathrm{~K}_{2} \mathrm{O} ; \mathrm{C} 3=130 \% \mathrm{~N}+100 \% \mathrm{~K}_{2} \mathrm{O}$ and $\mathrm{C} 4=160 \% \mathrm{~N}+125 \% \mathrm{~K}_{2} \mathrm{O}$ of the dose recommended for West Indian Cherry for the second year), each plot consisting of one plastic container with one plant, totaling 60 experimental units.

The recommendation of fertilization for the West Indian cherry cultivar 'Flor Branca' under irrigated conditions, corresponding to $100 \mathrm{~g}$ of $\mathrm{N}$ and $80 \mathrm{~g}$ of $\mathrm{K}_{2} \mathrm{O}$ per plant per year, was adopted (Cavalcanti, 2008), equivalent to the doses of the treatments with 100\% nitrogen (N) and potassium $\left(\mathrm{K}_{2} \mathrm{O}\right)$, whose quantities applied in the first and second years, along with phosphate fertilization, are presented in Table 1 . The combinations of $\mathrm{N}$ and $\mathrm{K}_{2} \mathrm{O}$ doses began to be applied at 20 days after transplanting (DAT) as top-dressing via water of $0.3 \mathrm{dS} \mathrm{m}^{-1}$ electrical conductivity for all treatments, using urea $(45 \% \mathrm{~N})$ and potassium chloride $(60 \%$ $\mathrm{K}_{2} \mathrm{O}$ ) as sources, respectively.

Salinity levels were based on the study conducted by Sá et al. (2018a), who observed that irrigation using water with a salinity of up to $2.2 \mathrm{dS} \mathrm{m}^{-1}$ does not compromise the growth and physiology of the West Indian cherry cv. 'BRS 336 Jaburu'.

The saline waters of the treatments were prepared based on the relationship between $\mathrm{ECW}$ and salt concentration $\left(\mathrm{mmol}_{\mathrm{c}} \mathrm{L}^{-1}=\mathrm{EC} \times 10\right)$, through the addition of $\mathrm{NaCl}, \mathrm{CaCl}_{2} \cdot 2 \mathrm{H}_{2} \mathrm{O}$, and $\mathrm{MgCl}_{2} .6 \mathrm{H}_{2} \mathrm{O}$, maintaining the equivalent ratio of $7: 2: 1$, respectively, to the water of the lowest salinity $\left(0.3 \mathrm{dS} \mathrm{m}^{-1}\right)$ from the Coremas-Mãe d'Água reservoir system, which provides water for irrigation in the region. The application of saline waters (1.3 to $\left.4.3 \mathrm{dS} \mathrm{m}^{-1}\right)$ began at 41 DAT, with irrigations performed manually every day based on the principle of drainage lysimeter. A leaching fraction of $15 \%$ was applied every 15 days, and the leaching volume was calculated based on the volume of water applied within these 15 days.

Containers with dimensions of $0.58 \mathrm{~m}$ (height), $0.42 \mathrm{~m}$ (upper diameter), and $0.32 \mathrm{~m}$ (lower diameter) were spaced in the field with $1.8 \times 2.0 \mathrm{~m}$ between plants and between planting rows, respectively. These containers were supported on ceramic bricks, $20 \mathrm{~cm}$ height from the soil, at the base of which was a drainage system, composed of a drain with a diameter of $1 / 2$ inch 
(12.7 $\mathrm{mm})$ inserted at the end of the base and coupled to a 2-L PET bottle to collect drained water; a 3.0-cm-layer of crushed stone $\mathrm{n}^{\circ} 1$ and a $2.0-\mathrm{cm}$-thick layer of washed sand were placed at the bottom of the pot. Above the sand, $56 \mathrm{~L}$ of soil were placed, and the soil's physical and chemical attributes (Table 2) were determined in the Irrigation and Salinity Laboratory of the Center of Technology and Natural Resources (CTRN) of UFCG, using methodologies recommended by Donagema et al. (2011).

Table 1. Quantities of $\mathrm{N}$ and $\mathrm{K}_{2} \mathrm{O}$ applied per plant through the combinations of nitrogen and potassium fertilization and phosphate fertilization, performed in the first and second years of cultivation, up to 550 days after transplantation (DAT).

\begin{tabular}{cccc}
\hline & \multicolumn{3}{c}{ Quantities applied per plant } \\
\cline { 2 - 4 } Fertilization combinations & $\begin{array}{c}\text { 1st year } \\
\text { (up to 365 DAT) }\end{array}$ & $\begin{array}{c}\text { 2nd year } \\
(365-550 \mathrm{DAT})\end{array}$ & $\begin{array}{c}\text { Total } \\
\text { (up to 550 DAT) }\end{array}$ \\
\hline $\mathrm{C} 1-70 \% \mathrm{~N}+50 \% \mathrm{~K}_{2} \mathrm{O}$ & $70 \mathrm{~g} \mathrm{~N}+40 \mathrm{~g} \mathrm{~K}_{2} \mathrm{O}$ & $35 \mathrm{~g} \mathrm{~N}+20 \mathrm{~g} \mathrm{~K} \mathrm{O}_{2}$ & $105 \mathrm{~g} \mathrm{~N}+60 \mathrm{~g} \mathrm{~K} \mathrm{O}$ \\
$\mathrm{C} 2-100 \% \mathrm{~N}+75 \% \mathrm{~K}_{2} \mathrm{O}$ & $100 \mathrm{~g} \mathrm{~N}+60 \mathrm{~g} \mathrm{~K}_{2} \mathrm{O}$ & $50 \mathrm{~g} \mathrm{~N}+30 \mathrm{~g} \mathrm{~K}_{2} \mathrm{O}$ & $150 \mathrm{~g} \mathrm{~N}+90 \mathrm{~g} \mathrm{~K}_{2} \mathrm{O}$ \\
$\mathrm{C} 3-130 \% \mathrm{~N}+100 \% \mathrm{~K}_{2} \mathrm{O}$ & $130 \mathrm{~g} \mathrm{~N}+80 \mathrm{~g} \mathrm{~K}_{2} \mathrm{O}$ & $65 \mathrm{~g} \mathrm{~N}+40 \mathrm{~K}_{2} \mathrm{O}$ & $195 \mathrm{~g} \mathrm{~N}+120 \mathrm{~g} \mathrm{~K}_{2} \mathrm{O}$ \\
$\mathrm{C} 4-160 \% \mathrm{~N}+125 \% \mathrm{~K}_{2} \mathrm{O}$ & $160 \mathrm{~g} \mathrm{~N}+100 \mathrm{~g} \mathrm{~K}_{2} \mathrm{O}$ & $80 \mathrm{~g} \mathrm{~N}+50 \mathrm{~K}_{2} \mathrm{O}$ & $240 \mathrm{~g} \mathrm{~N}+150 \mathrm{~g} \mathrm{~K}_{2} \mathrm{O}$
\end{tabular}

Phosphate fertilization $\left(\mathrm{P}_{2} \mathrm{O}_{5}\right)$

\[ 20 \mathrm{~g} \]
\[ - \]
Note: The combinations of $\mathrm{N}$ and $\mathrm{K}_{2} \mathrm{O}$ doses were applied at an interval of 15 days. Phosphate
fertilization in the first year was performed with single superphosphate $\left(18 \% \mathrm{P}_{2} \mathrm{O}_{5}\right)$, by mixing the
fertilizer with the soil of the lysimeter, and in the second year, split into 12 applications of equal
portions, at an interval of 15 days, using monoammonium phosphate - $\mathrm{MAP}\left(61 \% \mathrm{P}_{2} \mathrm{O}_{5}\right.$ and $12 \%$
$\mathrm{N})$; the quantity of $\mathrm{N}$ supplied was subtracted from the doses of treatments with nitrogen
fertilization.

The seedlings came from a commercial nursery accredited in the National Registry of Seeds and Seedlings, located in the District of São Gonçalo, Sousa - PB, grafted by the full cleft method, using rootstock and scion of the cultivars 'Junco' and 'Flor Branca', respectively. Transplanting to the containers was performed when the seedlings reached $30 \mathrm{~cm}$ in height, at 120 days after grafting. After transplanting, a 4.0-cm-thick layer of mulch, composed of grass residues, was maintained to minimize water losses by evaporation.

The effects of treatments on plant physiology were analyzed at 540 DAT, through water potential in the branch $(\Psi \mathrm{w})$, relative water content (RWC), water saturation deficit (WSD) and intercellular electrolyte leakage (EL) in the leaf blade, chlorophyll contents in leaves (CHLtotal), stomatal conductance (gs), and $\mathrm{CO}_{2}$ assimilation rate (A). 
Table 2. Physical and chemical attributes of the 0-0.20 m soil layer (Neossolo Flúvico Eutrófico - Entisol) used in the experiment, before application of the treatments, collected in Lot 14, Sector I, of the Irrigated Perimeter of Várzeas de Sousa-PB, Brazil.

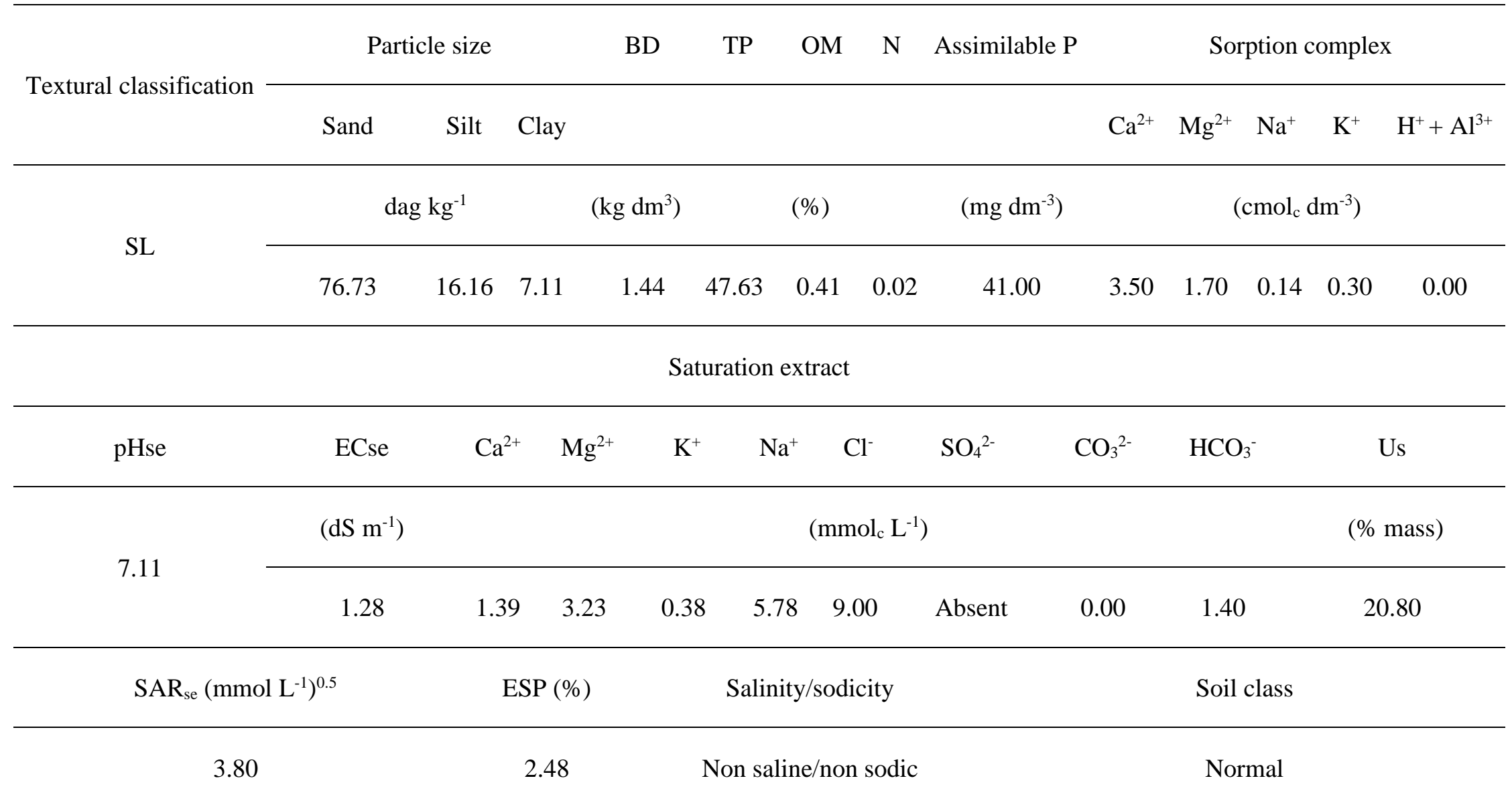

SL - Sandy loam; BD - Bulk density; TP - Total porosity; OM - Organic matter determined by Walkley-Black wet digestion; $\mathrm{pHse}$ - $\mathrm{pH}$ of saturation extract, ECse - electrical conductivity of saturation extract at $25^{\circ} \mathrm{C}$; Us - soil saturation moisture; SAR $\mathrm{Se}_{\mathrm{se}}$ - Sodium adsorption ratio of saturation extract; ESP - exchangeable sodium percentage; $\mathrm{P}, \mathrm{K}^{+}$and $\mathrm{Na}^{+}$extracted with Mehlich-1 extractant; $\mathrm{Ca}^{2+}$ and $\mathrm{Mg}^{2+}$ extracted with 1.0 $\mathrm{M} \mathrm{KCl}$ at $\mathrm{pH} 7.0 ; \mathrm{H}^{+}+\mathrm{Al}^{3+}$ extracted by $0.5 \mathrm{M} \mathrm{CaOAc}$ at $\mathrm{pH}$ 7.0. 
The $\Psi_{\mathrm{W}}$ was analyzed in a pressure chamber (Scholander et al., 1965), in the terminal part of the branch removed with an approximate length of $15 \mathrm{~cm}$ and detached from the plant where the diameter reached $1.9 \mathrm{~mm}$, in the median region of the crown at 6:30 a.m. RWC and WSD were determined in 4 fully expanded leaves, taken from the intermediate third of branches located in the same region of the crown where the branches were collected for the $\Psi_{\mathrm{w}}$ evaluation, adopting methodologies of Weatherley (1950) and Taiz et al. (2017), respectively.

Electrolyte leakage in the cell membrane was determined according to Bajji et al. (2002), in eight leaf discs collected from four leaves located in the middle third of the branch, in the median region of the crown. Total chlorophyll content was determined by the sum of chlorophyll a and chlorophyll $b$ contents, analyzed in 6 discs of plant tissue taken from the middle third of the fourth pair of leaves of a branch located in the median region of the crown, corresponding to a total disc area of $3.18 \mathrm{~cm}^{2}$, using the methodology of Lichtenthäler (1987). The data were obtained in $\mathrm{mg} \mathrm{L}^{-1}$ and, based on the leaf disc area $\left(3.18 \mathrm{~cm}^{2}\right)$ and dilution of the extract in $80 \%$ acetone $(6 \mathrm{~mL})$, were transformed into units of mass per $\mathrm{m}^{2}\left(\mathrm{~g} \mathrm{~m}^{-2}\right.$ fresh weight).

Stomatal conductance and $\mathrm{CO}_{2}$ assimilation rate were analyzed between 6:00 and 9:00 a.m., in the same region of the plant in which the other physiological variables mentioned above were analyzed, using a portable infrared carbon dioxide analyzer (IRGA), LCPro+ Portable Photosynthesis System ${ }^{\circledR}$ model (ADC BioScientific Limited, UK), operating at room temperature, irradiation of $1200 \mu \mathrm{mol}$ photons $\mathrm{m}^{-2} \mathrm{~s}^{-1}$ and airflow of $200 \mathrm{~mL} \mathrm{~min} \mathrm{~m}^{-1}$, and atmospheric $\mathrm{CO}_{2}$ concentration.

Fruit formation variables were analyzed in ripe harvested fruits with intense red peel, at harvests performed between 420 and 550 DAT, through the equatorial (ED) and polar diameter (PD), average fruit size (AFS) and average fruit mass (AFM). The measurements were taken in a representative sample of 15 fruits per plant, randomly selected from the total fruits collected. PD was measured in the direction from the base to the apex of the fruit, and ED in the median region in the direction of width, using a digital caliper. AFS was obtained by means of PD and ED. AFM was determined by dividing the total weight of fruits, weighed on a precision scale $(0.01 \mathrm{~g})$, by the number of fruits harvested.

The data were subjected to analysis of variance by the F test at 0.01 and 0.05 probability levels; the means of salinity levels were analyzed by regression and the means of combinations of nitrogen and potassium fertilization were compared by Tukey test at 0.05 probability level, using the statistical program SISVAR, Version 5.6 for data processing (Ferreira, 2014).

\section{RESULTS AND DISCUSSION}

The interaction between irrigation water salinity and the combination of NK doses was not significant $(\mathrm{p}>0.05)$ for the physiological and fruit production of West Indian cherry in the second year of cultivation (Table 3 ). However, there was a significant single effect $(p<0.05)$ of water salinity on the water potential in the branch, water saturation deficit, relative water content in the leaf, electrolyte leakage in the leaf blade, total chlorophyll, $\mathrm{CO}_{2}$ assimilation rate, equatorial and polar diameters of the fruits, as well as their average size and average mass. These variables were also significantly influenced by the combination of NK doses, except for the water saturation deficit and relative water content, whereas stomatal conductance was not affected by any of the factors.

Despite reports of the positive influence of $\mathrm{N}$ and $\mathrm{K}$ on the mitigation of salt stress in plants (Andrade Junior et al., 2011; Ashraf et al., 2018; Hasanuzzaman et al., 2018), the noninteractive effect between the factors (Table 3) shows that the combinations of $\mathrm{N}$ and $\mathrm{K}$ doses were not efficient in reducing the nutritional imbalance caused by toxic ions $\mathrm{Na}^{+}$and $\mathrm{Cl}^{-}$, thus not mitigating salt stress on the physiological traits and fruit production, as can be seen further on in this study. Sá et al. (2018b) also observed that there was no significant effect of the interaction between levels of irrigation water salinity and combinations of nitrogen and

Rev. Ambient. Água vol. 16 n. 6, e2780 - Taubaté 2021 
phosphate fertilization on the relative water content, water saturation deficit, percentage of electrolyte leakage, longitudinal and transverse diameters of fruits and average fruit mass, in West Indian cherry in the first year of cultivation.

Table 3. Summary of the analysis of variance for water potential in the branch $\left(\Psi_{w}\right)$, relative water content (RWC), water saturation deficit in the leaf (WSD), electrolyte leakage in the leaf blade (EL), total chlorophyll content in the leaf (CHLtotal), stomatal conductance (gs) and $\mathrm{CO}_{2}$ assimilation rate (A) at 540 days after transplanting and, polar diameter (PD), equatorial diameter (ED), average fruit size (AFS) and average fruit mass (AFM) obtained from harvests performed between 420 and 550 days after transplanting, in West Indian cherry irrigated with waters of different salinities, under combinations of nitrogen and potassium fertilization.

\begin{tabular}{|c|c|c|c|c|c|c|c|c|}
\hline \multirow{2}{*}{ Source of variation } & \multirow[b]{2}{*}{$\mathrm{DF}$} & \multicolumn{7}{|c|}{ Mean squares } \\
\hline & & $\Psi_{\mathrm{w}}$ & RWC & \multicolumn{2}{|c|}{ WSD } & EL & CHLtotal & gs \\
\hline Salinity (S) & 4 & $0.149 * * \quad 9$ & $97.24 * *$ & \multicolumn{2}{|c|}{$97.24 * *$} & $396.59 * *$ & $0.0116^{* *}$ & $0.00024^{\mathrm{ns}}$ \\
\hline NK combination (C) & 3 & $0.171 * *$ & $2.77^{\mathrm{ns}}$ & \multicolumn{2}{|c|}{$2.77^{\mathrm{ns}}$} & $97.88 * *$ & $0.0101 * *$ & $0.00006^{\mathrm{ns}}$ \\
\hline $\mathrm{S} * \mathrm{C}$ Interaction & 12 & $0.034^{\mathrm{ns}}$ & $15.55^{\mathrm{ns}}$ & \multicolumn{2}{|c|}{$15.55^{\mathrm{ns}}$} & $8.22^{\mathrm{ns}}$ & $0.0013^{\mathrm{ns}}$ & $0.00015^{\mathrm{ns}}$ \\
\hline Block & 2 & $0.034^{\mathrm{ns}} \quad 9$ & $95.17 * *$ & \multicolumn{2}{|c|}{$95.17 * *$} & $40.52^{\mathrm{ns}}$ & $0.0007^{\mathrm{ns}}$ & $0.00408 * *$ \\
\hline Error & 38 & 0.024 & 16.66 & \multicolumn{2}{|c|}{16.66} & 17.90 & 0.0016 & 0.00027 \\
\hline $\mathrm{CV}(\%)$ & - & 6.22 & 5.31 & \multicolumn{2}{|c|}{17.60} & 21.62 & 23.28 & 42.48 \\
\hline Source of variation & $\mathrm{DF}$ & A & \multicolumn{2}{|c|}{$\mathrm{PD}$} & \multicolumn{2}{|c|}{$\mathrm{ED}$} & AFS & AFM \\
\hline Salinity (S) & 4 & $9.49 *$ & \multicolumn{2}{|c|}{$8.099 * *$} & \multicolumn{2}{|c|}{$10.515^{* *}$} & $8.552 * *$ & $0.928 * *$ \\
\hline NK combination (C) & 3 & $16.88^{* *}$ & \multicolumn{2}{|c|}{$3.406^{* *}$} & \multicolumn{2}{|c|}{$4.601 * *$} & $3.896^{* *}$ & $0.440 * *$ \\
\hline $\mathrm{S} * \mathrm{C}$ Interaction & 12 & $4.21^{\mathrm{ns}}$ & \multicolumn{2}{|c|}{$0.475^{\mathrm{ns}}$} & \multicolumn{2}{|c|}{$0.788^{\mathrm{ns}}$} & $0.596^{\mathrm{ns}}$ & $0.117^{\mathrm{ns}}$ \\
\hline Block & 2 & $27.82 * *$ & \multicolumn{2}{|c|}{$1.538^{\mathrm{ns}}$} & \multicolumn{2}{|c|}{$2.776^{*}$} & $1.959^{*}$ & $0.276^{*}$ \\
\hline Error & 38 & 3.05 & \multicolumn{2}{|c|}{0.3009} & \multicolumn{2}{|c|}{0.5522} & 0.4992 & 0.0839 \\
\hline $\mathrm{CV}(\%)$ & - & 36.85 & \multicolumn{2}{|c|}{3.87} & \multicolumn{2}{|c|}{4.61} & 4.65 & 12.70 \\
\hline
\end{tabular}

$*$ and ${ }^{* *}$, respectively significant at $\mathrm{p}<0.05$ and $\mathrm{p}<0.01$; ns - not significant; DF - degrees of freedom; CV

- coefficient of variation.

It can be observed (Figure 1A) that the increase in irrigation water salinity reduced the water potential in the branch of West Indian cherry plants by $2.58 \%$ per unit increase in ECw. It must be pointed out that this phenomenon results from the accumulation of organic solutes in the cytosol and ions in the vacuole of cells in response to salt stress to carry out the osmotic adjustment; with this occurring the decrease of the internal water potential in the tissue of the branches (Silva et al., 2016; Sá et al., 2019). 

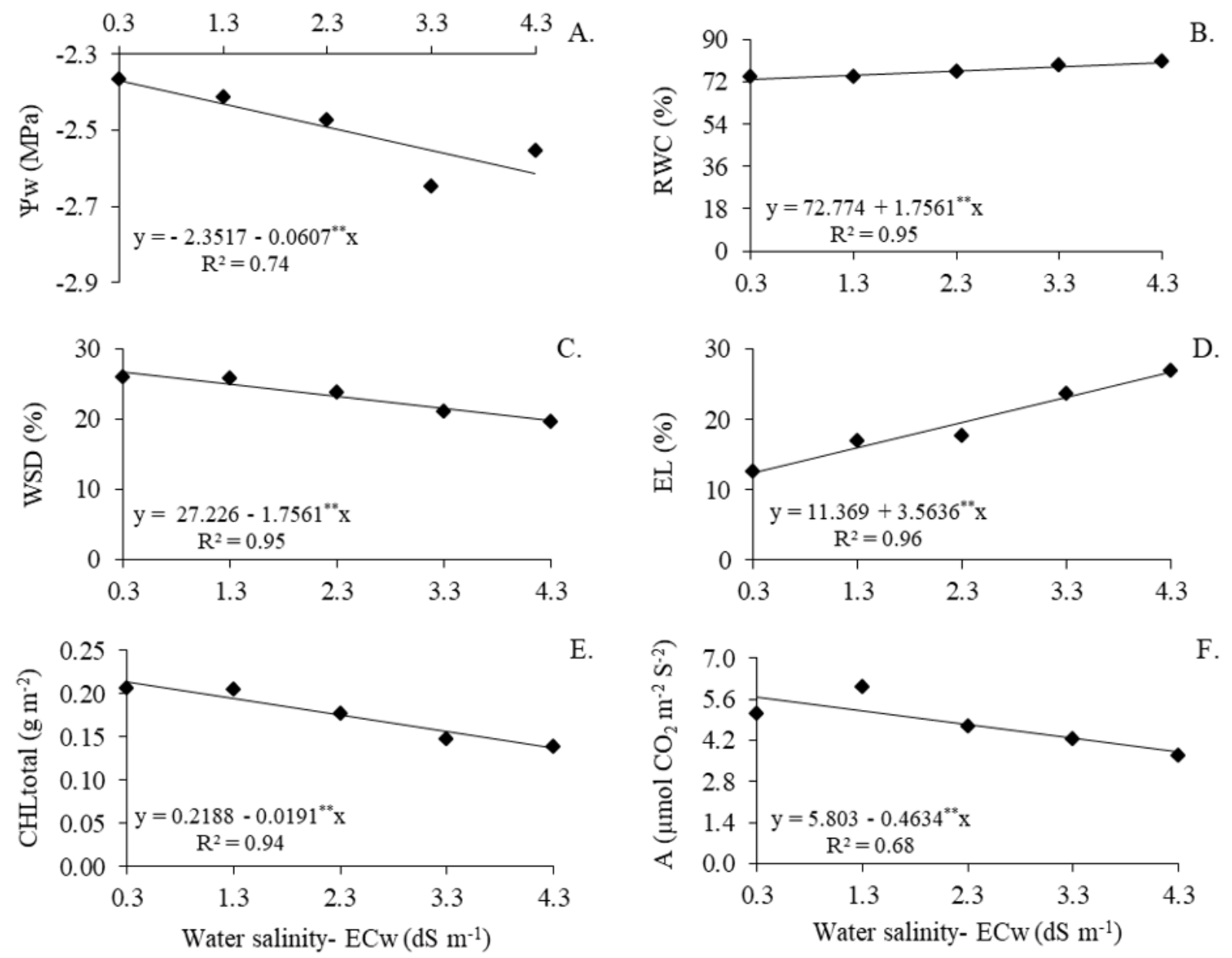

Figure 1. Water potential in the branch - $\Psi_{\mathrm{W}}(\mathrm{A})$, relative water content - RWC (B), water saturation deficit - WSD (C) and electrolyte leakage in the leaf blade - EL (D), total chlorophyll content in the leaf - CHLtotal (E), and $\mathrm{CO}_{2}$ assimilation rate $(\mathrm{F})$, in West Indian cherry irrigated with waters of different salinities at 540 days after transplantation.

The relative water content in the leaf increased with a linear increase of $2.41 \%$ per unit of $\mathrm{ECw}$ (Figure 1B), which resulted in a decrease in the water saturation deficit in the leaf by $6.45 \%$ per unit increment in ECw (Figure 1C). These effects are probably related to osmotic adjustment, due to the accumulation of organic solutes in the cytosol and ions in the vacuole of cells, which contributed to increased water absorption by these tissues through an osmotic gradient, resulting in greater turgescence in the leaves; this was also proven in the present study by the non-significant effect of water salinity on stomatal conductance (Table 3), probably due to the maintenance of turgor of stomatal guard cells. The increase in the water content in the leaves with increasing salinity in irrigation water was also observed in cashew plants by Carneiro et al. (2002), who associated this phenomenon with the effect of osmotic adjustment, by the accumulation of ions in the vacuole of cells and the synthesis of organic compounds.

Figure 1D shows that the increase in irrigation water salinity linearly intensified electrolyte leakage in leaf blade cells, resulting in a $31.35 \%$ per unit increase in water salinity level. The increase in the extrusion of electrolytes is associated with the toxic effects of $\mathrm{Na}^{+}$and $\mathrm{Cl}^{-}$ions accumulated in the leaves, which promote structural changes in cell membranes, with consequent rupture (Ferraz et al., 2015), and with the increase of reactive oxygen species, which cause lipid peroxidation and oxidation of the cell membranes and organelles, resulting in degradation and, consequently, loss of internal content of the cells (Mendes et al., 2011).

Figures $1 \mathrm{E}$ and $1 \mathrm{~F}$ show that the total chlorophyll content in the leaves and the $\mathrm{CO}_{2}$ assimilation rate were reduced by the increase in salt stress caused by irrigation water, with 
linear reductions, respectively, of 8.73 and $7.98 \%$ per unit increase in $\mathrm{ECw}$. The decrease in chlorophyll content in leaves is associated with the degradation of chloroplasts due to the rupture of their membranes (Sousa et al., 2017) and with the increase in the activity of the chlorophyll enzyme, which degrades the molecules of these photosynthesizing pigments under conditions of salt stress (Sá et al., 2019a).

For the $\mathrm{CO}_{2}$ assimilation rate, the decrease may have resulted from the degradation of chlorophyll molecules, which reduces the photochemical efficiency in Photosystem II, resulting in the low formation of the NADPH reducer and ATP. These substances are used as an energy source for $\mathrm{CO}_{2}$ assimilation, and decrease the efficiency of carboxylation of the RuBisCO enzyme responsible for carbon fixation for photosynthesis (Taiz et al., 2017); this is generally affected by the increase of $\mathrm{Cl}^{-}$in the leaves (Silva et al., 2016), a phenomenon already reported in West Indian cherry crops subjected to salt stress (Alvarenga et al., 2019; Lima et al., 2019a; Sá et al., 2019).

It can be observed (Figure 2A) that the water potential in the branch of plants under the fertilization combinations $\mathrm{C} 1, \mathrm{C} 2$ and $\mathrm{C} 3$ did not differ statistically, while fertilization with the combination $\mathrm{C} 4$ resulted in a lower value of this variable. The application of high doses of $\mathrm{N}$ and $\mathrm{K}(160 / 125 \%)$ through $\mathrm{C} 4$ may have resulted in nutritional imbalance and excessive accumulation of $\mathrm{NO}_{3}{ }^{-}$and $\mathrm{K}^{+}$in the cellular vacuole of leaves and branches, causing an osmotic gradient (Ashraf et al., 2018; Hasanuzzaman et al., 2018), resulting in the reduction of free energy of water, leading to reduction in the internal water potential of the branch.

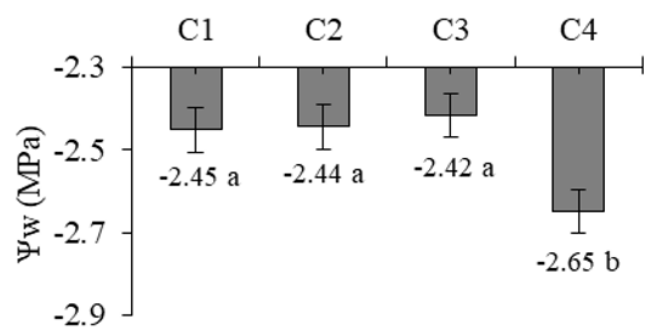

A.

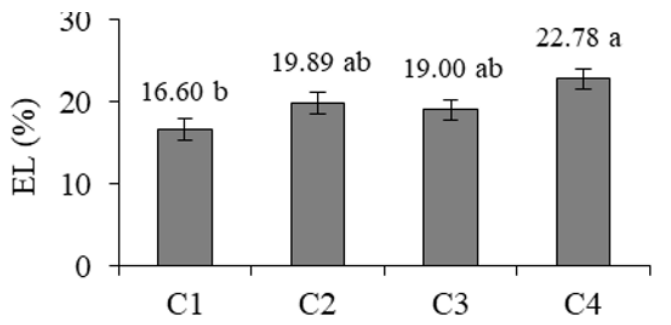

B.

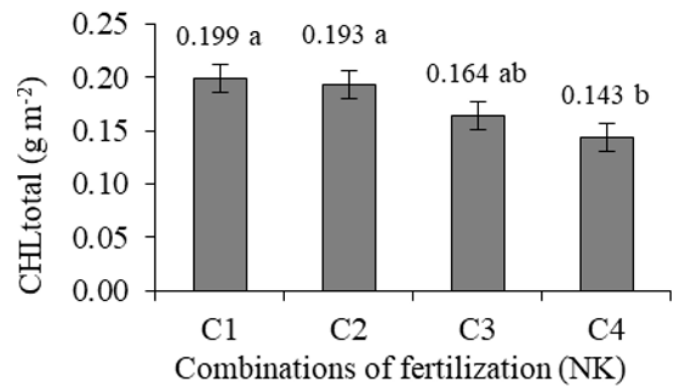

C.

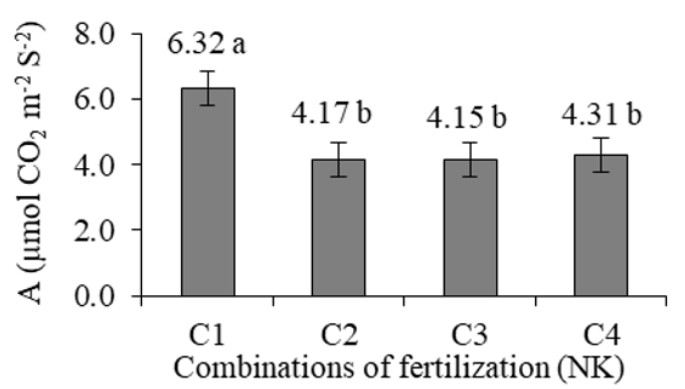

$\mathrm{C} 1-70 \% \mathrm{~N}+50 \% \mathrm{~K}_{2} \mathrm{O} ; \mathrm{C} 2-100 \% \mathrm{~N}+75 \% \mathrm{~K}_{2} \mathrm{O} ; \mathrm{C} 3-130 \% \mathrm{~N}+100 \% \mathrm{~K}_{2} \mathrm{O}$ and $\mathrm{C} 4-160 \% \mathrm{~N}+125 \% \mathrm{~K}_{2} \mathrm{O}$; means followed by different letters indicate significant difference between treatments by Tukey test $(\mathrm{p}<0.05)$. Vertical bars represent the standard error of the mean $(n=3)$.

Figure 2. Water potential in the branch - $\Psi_{\mathrm{w}}(\mathrm{A})$, electrolyte leakage in the leaf blade - EL (B), total chlorophyll - CHLtotal (C), and $\mathrm{CO}_{2}$ assimilation rate - A (D) in West Indian cherry leaves, as a function of different combinations of nitrogen and potassium fertilization at 540 days after transplantation.

Figure $2 \mathrm{~B}$ shows that the percentage of electrolyte leakage in the leaf blade was lower in plants fertilized with the combination $\mathrm{C} 1$, while the total chlorophyll content and the $\mathrm{CO}_{2}$ assimilation rate obtained higher values with the use of this fertilization combination (Figures 2C and 2D). On the other hand, the increase in NK doses intensified electrolyte leakage and reduced the total chlorophyll content and the $\mathrm{CO}_{2}$ assimilation rate, mainly under the use of the C4 fertilization combination. 
The $\mathrm{C} 1$ combination may have promoted greater nutritional balance, resulting in lower electrolyte extrusion and higher chlorophyll content and $\mathrm{CO}_{2}$ assimilation rate in plants due to the application of adequate doses of nitrogen and potassium, given that $\mathrm{N}$ is an integral component of proteins that make up cell membranes, improving their permeability and selectivity (Ashraf et al., 2018), besides being one of the main constituents of chlorophyll molecules (Taiz et al., 2017). In addition, $\mathrm{K}$ can decrease the formation of reactive oxygen species, ensuring greater integrity of cell membranes and chloroplasts, with positive contributions to cationic balance and osmoregulation (Almeida et al., 2017; Hasanuzzaman et $a l ., 2018$ ), besides stimulating the activity of RuBisCO, which contributes to an increase in $\mathrm{CO}_{2}$ assimilation rate (Taiz et al., 2017).

On the other hand, it is emphasized that the high doses of NK applied through $\mathrm{C} 4$ may have caused increased oxidative stress, leading to greater damage to cell membranes and chlorophyll molecules; this phenomenon may occur mainly with increased doses of nitrogen, which provides excess ammonium, where plants have greater sensitivity (Kováčik et al., 2020). The decrease in $\mathrm{CO}_{2}$ assimilation rate in the $\mathrm{C} 2, \mathrm{C} 3$, and $\mathrm{C} 4$ combinations is also related to an excessive amount of $\mathrm{N}$, which may have promoted increased oxygenase activity of the RuBisCO enzyme to the detriment of carboxylase, and $\mathrm{K}$ causing decreased activity of the $\mathrm{CO}_{2-}$ fixing enzyme (RuBisCO) (Melo et al., 2009).

Regarding fruit characteristics, it can be observed (Figures 3A, 3B, 3C, and 3D) that the increase in the salinity level of irrigation water negatively affected the equatorial and polar diameters, average size and average mass of the fruits, causing decreases with per unit increment in ECw of 3.12, 2.99, 2.50, and 5.21\% in these variables, respectively. This is due to the higher energy cost to perform osmotic adjustment with increased salinity, through the synthesis of organic solutes and diversion of these substrates that would be transferred and accumulated in the fruits in the form of starch, proteins and cell wall (Taiz et al., 2017).

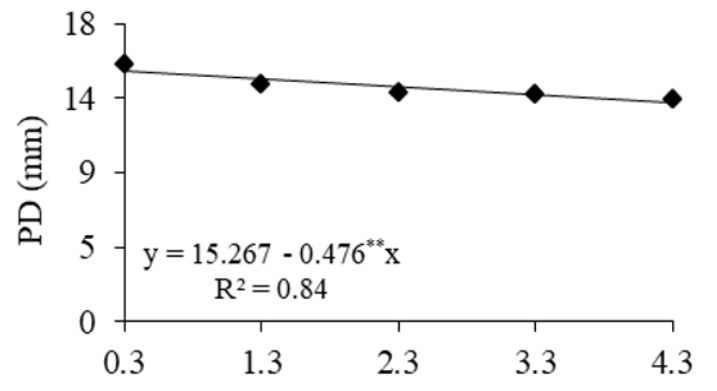

A.
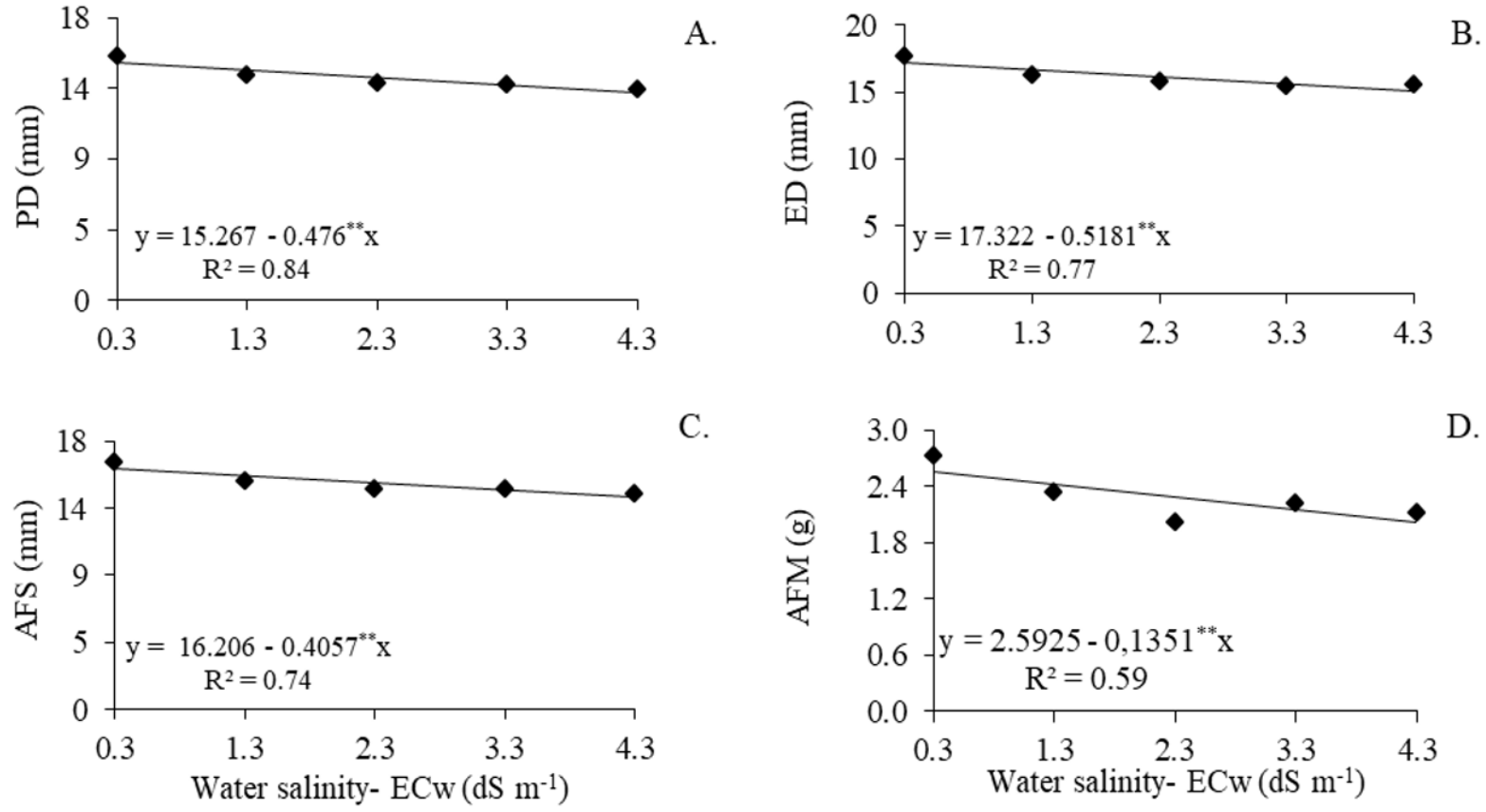

C.

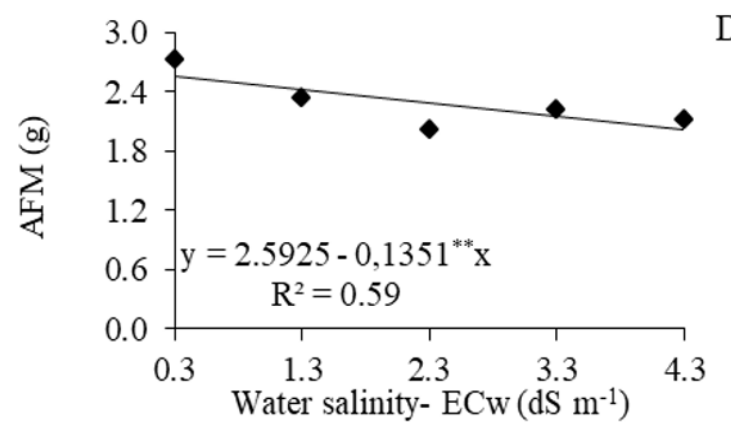

Figure 3. Polar diameter - PD (A), equatorial diameter - ED (B), average fruit size - AFS (C), and average fruit mass - AFM (D) of West Indian cherry, as a function of irrigation water salinity - ECw, of fruit harvests carried out between 420 and 550 days after transplanting.

This phenomenon is also associated with a decrease in $\mathrm{CO}_{2}$ assimilation rate, which reduced the synthesis of assimilates that would be transferred and accumulated in fruits, and with physiological disturbances caused by increased formation of reactive oxygen species, 
which damage cell membranes, chlorophylls, proteins, lipids and nucleic acids (Mendes et al., 2011; Sousa et al., 2017; Ashraf et al., 2018). Similarly, Sá et al. (2019) observed a decrease in the longitudinal diameter and mass of fruits of 'BRS Jaburu' irrigated by water with salinity ranging from 0.6 to $3.8 \mathrm{dS} \mathrm{m}^{-1}$ at 365 days after transplanting. Also, Lima et al. (2019b) found a reduction in the average fruit mass of this cultivar caused by irrigation with $\mathrm{ECw}$ from $3.8 \mathrm{dS}$ $\mathrm{m}^{-1}$ at 515 days after transplanting.

By analyzing the effect of fertilization combinations on West Indian cherry fruits, it was observed (Figures 4A, 4B, 4C, and 4D) that the largest polar diameter, equatorial diameter, average size, and average mass of fruits were obtained in plants fertilized with the combination $\mathrm{C} 1$, followed by the combination $\mathrm{C} 2$. This effect may be related to the positive influence of the adequate doses of $\mathrm{N}$ and $\mathrm{K}$ supplied through these combinations on physiological and biochemical processes. These phenomena were proven in the present study by fertilization with the combination $\mathrm{C}$ 1, in which the plants showed lower electrolyte leakage, higher concentration of total chlorophyll in leaves, and a higher $\mathrm{CO}_{2}$ assimilation rate (Figures 2B, 2C, and 2D).
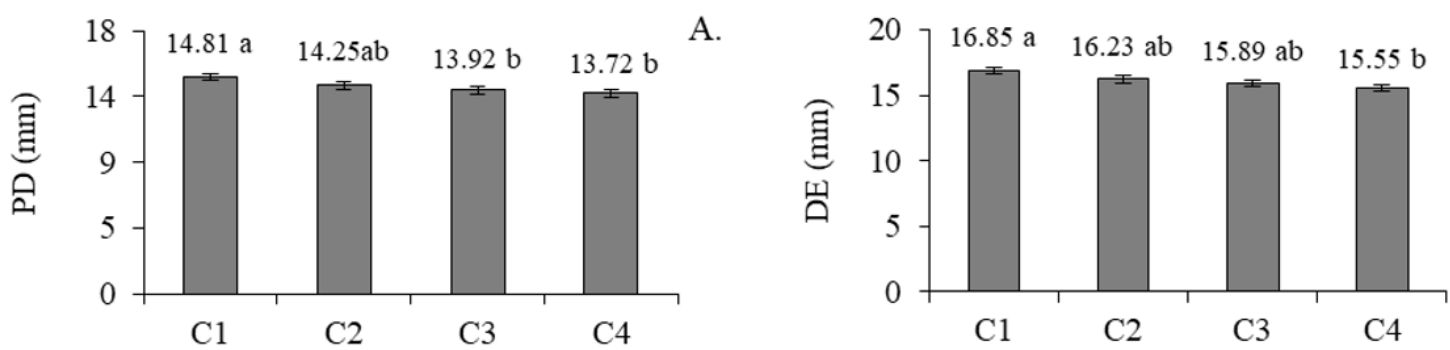

B.

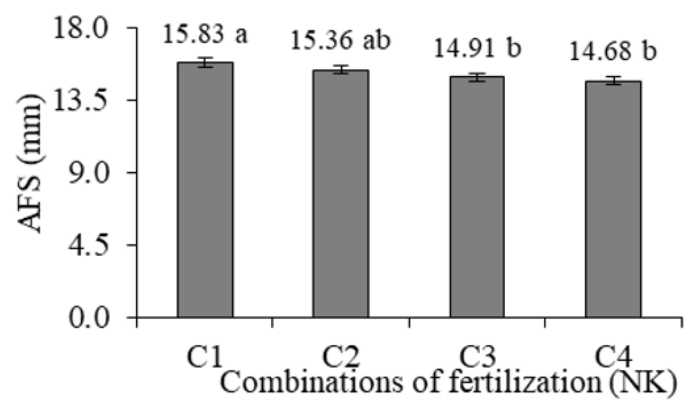

C.

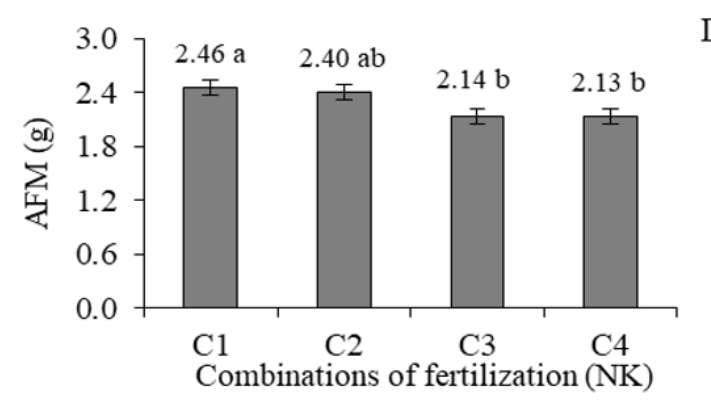

$\mathrm{C} 1-70 \% \mathrm{~N}+50 \% \mathrm{~K}_{2} \mathrm{O} ; \mathrm{C} 2-100 \% \mathrm{~N}+75 \% \mathrm{~K}_{2} \mathrm{O} ; \mathrm{C} 3-130 \% \mathrm{~N}+100 \% \mathrm{~K}_{2} \mathrm{O}$ and $\mathrm{C} 4-160 \% \mathrm{~N}+125 \% \mathrm{~K}_{2} \mathrm{O}$; means followed by different letters indicate significant difference between treatments by Tukey test $(\mathrm{p}<0.05)$. Vertical bars represent the standard error of the mean $(n=3)$.

Figure 4. Polar diameter - PD (A) and equatorial - ED (B), average fruit size - AFS (C), and average fruit mass - AFM (D) of West Indian cherry, as a function of different combinations of nitrogen and potassium fertilization, in fruit harvests performed between 420 and 550 days after transplanting.

Regarding the lower values observed, mainly under the fertilization combination $\mathrm{C} 4$ $\left(160 \% \mathrm{~N}+125 \% \mathrm{~K}_{2} \mathrm{O}\right)$, it is possible to affirm that, in addition to nutritional imbalance and oxidative stress, these doses increased salinity in the soil solution as a result of the increase in the amount of nitrogen and potassium fertilizers applied, harmed the physiological activities and fruit formation of West Indian cherry plants, since urea and potassium chloride used as a source of $\mathrm{N}$ and $\mathrm{K}$ have high salt indices, corresponding to 75 and $115 \%$, respectively (Borges and Silva, 2011).

\section{CONCLUSIONS}

1. The different combinations of nitrogen and potassium doses did not mitigate the harmful effects of salt stress on plant physiology and fruit production but impaired these variables with 
doses from $100 \% \mathrm{~N}+75 \% \mathrm{~K}_{2} \mathrm{O}$.

2. Irrigation using water with salinity above $0.3 \mathrm{dS} \mathrm{m}^{-1}$ intensifies intercellular electrolyte leakage (EL), reduces water potential in plants, total chlorophyll content in leaves, and $\mathrm{CO}_{2}$ assimilation rate, reducing the diameter and mass of West Indian cherry fruits in the second year of cultivation.

3. Plants fertilized with $70 \% \mathrm{~N}+50 \% \mathrm{~K}_{2} \mathrm{O}$ of the recommended dose have lower EL, higher $\mathrm{CO}_{2}$ assimilation rate, higher chlorophyll content in leaves, and produce fruits with larger diameter and mass, regardless of the salinity of the irrigation water.

\section{ACKNOWLEDGEMENTS}

To the Universidade Federal de Campina Grande - UFCG for the use of infrastructure and to the Coordenação de Aperfeiçoamento de Pessoal de Nível Superior (CAPES) for the research fellowship.

\section{REFERENCES}

ALMEIDA, D. M.; OLIVEIRA, M. M.; SAIBO, N. J. M. Regulation of $\mathrm{Na}^{+}$and $\mathrm{K}^{+}$homeostasis in plants: Towards improved salt stress tolerance in crop plants. Genetics and Molecular Biology, v. 40, n. 1, p. 326-345, 2017. https://doi.org/10.1590/1678-4685-GMB-20160106

ALVARENGA, C. F. S.; SILVA, E. M. da; NOBRE, R. G.; GHEYI, H. R.; LIMA, G. S. de; SILVA, L. de À. Morfofisiologia de aceroleira irrigada com águas salinas sob combinações de doses de nitrogênio e potássio. Revista de Ciências Agrárias, v. 42, n. 1, p. 194-205, 2019. https://doi.org/10.19084/RCA18215

ANDRADE JÚNIOR, W. P.; PEREIRA, F. H. F.; FERNANDES, O. B.; QUEIROGA, R. C. F.; QUEIROGA, F. M. de. Efeito do nitrato de potássio na redução do estresse salino no meloeiro. Revista Caatinga, v. 24, n. 3, p. 110-119, 2011.

ASHRAF, M.; SHAHZAD, S. M.; IMTIAZ, M.; RIZWAN, M. S.; ARIF, M. S.; KAUSAR, R. Nitrogen nutrition and adaptation of glycophytes to saline environment: a review. Archives of Agronomy and Soil Science, v. 64, n. 9, p. 1181-1206, 2018. https://doi.org/10.1080/03650340.2017.1419571

BAJJI, M.; KINET, J. M.; LUTTS, S. The use of the electrolyte leakage method for assessing cell membrane stability as a water stress tolerance test in durum wheat. Plant Growth Regulation, v. 36, n. 1, p. 61-70, 2002.

BORGES, A. L.; SILVA, D. J. Fertilizantes para fertirrigação. In: SOUSA, V. F. de; MAROUElli, W. A.; COELHO, E. F.; PINTO, J. M.; COELHO FILHO, M. A. (ed.). Irrigação e fertirrigação em fruteiras e hortaliças. Brasília: Embrapa Informação Tecnológica, 2011. p.253-264.

CARNEIRO, P. T.; FERNANDES, P. D.; GHEYI, H. R.; SOARES, F. A .L. Germinação e crescimento inicial de genótipos de cajueiro anão-precoce em condições de salinidade. Revista Brasileira de Engenharia Agrícola e Ambiental, v. 6, n. 2, p. 199-206, 2002.

CAVAlCANTI, F. J. A. Recomendações de adubação para o Estado de Pernambuco: 2. aproximação. 3. ed. Recife: IPA, 2008. 212 p. 
DONAGEMA, G. K.; CAMPOS, D. V. B. de; CALDERANO, S. B.; TEIXEIRA, W. G.; VIANA, J. H. M. Manual de métodos de análise de solo. Rio de Janeiro: Embrapa Solos, 2011.230p.

ESASHIKA, T.; OLIVEIRA, L. A. de; MOREIRA, F. W. Resposta da aceroleira a adubação orgânica, química e foliar num Latossolo da Amazônia Central. Revista de Ciências Agrárias, v. 36, n. 4, p. 399-410, 2013. https://doi.org/10.19084/rca.16325

FERRAZ, R. L. S.; MAGALHÃES, I. D.; BELTRÃO, N. E. de M.; MELO, A. S. de; BRITO NETO, J. F. de; ROCHA, M. do S. Photosynthetic pigments, cell extrusion and relative leaf water content of the castor bean under silicon and salinity. Revista Brasileira de Engenharia Agrícola e Ambiental, v. 19, n. 9, p. 841-848, 2015. http://dx.doi.org/10.1590/1807-1929/agriambi.v19n9p841-848

FERREIRA, D. F. Sisvar: a guide for its bootstrap procedures in multiple comparisons. Ciência e Agrotecnologia, v. 38, n. 2, p. 109-112, 2014. http://dx.doi.org/:10.1590/S141370542014000200001

FLOWERS, T. J.; MUNNS, R.; COLMER, T. D. Sodium chloride toxicity and the cellular basis of salt tolerance in halophytes. Annals of Botany, v. 115, n. 3, p. 419-431, 2014. http://dx.doi.org/10.1093/aob/mcu217

HASANUZZAMAN, M.; BHUYAN, M. H. M. B.; NAHAR, K.; HOSSAIN, M. S.; MAHMUD, J. A.; HOSSEN, M. S. Potassium: a vital regulator of plant responses and tolerance to abiotic stresses. Agronomy, v. 8, n. 3; p. 1-29, 2018. https://doi.org/10.3390/agronomy8030031

INMET. Estações dados. Available at: http://www.inmet.gov.br/portal/index.php?r=estacoes/estacoesAutomaticas Access: 30 Oct. 2018.

IBGE. Produção e área nos estabelecimentos agropecuários com mais de 50 pés existentes. Rio de Janeiro: IBGE, 2017.

KOVÁČIK, J.; DRESLER, S.; PETERKOVÁ, V.; BABULA, P. Nitrogen nutrition modulates oxidative stress and metabolite production in Hypericum perforatum. Protoplasma, v. 257, n. 1, p. 439-447, 2020. https://doi.org/10.1007/s00709-019-01448-1

LICHTENTHÄLER, H. K. Chlorophylls and carotenoids: pigments of photosynthetic biomembranes. In: PACKER, L.; DOUCE, R. Methods in enzimology. London: Academic Press, 1987. v. 148, p. 350-381.

LIMA, G. S. de; ANDRADE, E. M. G.; KETOUNOU, T. R.; LIMA, V. L. A. de; GHEYI, H. R.; SILVA, S. S. da et al. Photosynthesis, photochemical efficiency and growth of West Indian cherry cultivated with saline waters and nitrogen fertilization. Bioscience Journal, v. 35, n. 1, p. 67-78, 2019a. http://orcid.org/0000-0001-9960-1858

LIMA, G. S. de; PINHEIRO, F. W. A.; DIAS, A. S.; GHEYI, H. R.; SOARES, L. A. dos A.; SILVA, S. S. da. Growth and production components of West Indian cherry cultivated with saline waters and potassium fertilization. Revista Brasileira de Engenharia Agrícola e Ambiental, v. 23, n. 4, p. 250-256, 2019 b. 
MELO, A. S.; SILVA JÚNIOR, C. D. da; FERNANDES, P. D.; SOBRAL, L. F.; BRITO, M. E. B.; DANTAS, J. D. M. Alterações das características fisiológicas da bananeira sob condições de fertirrigação. Ciência Rural, v. 39, n. 3, p. 733-741, 2009. http://dx.doi.org/10.1590/S0103-84782008005000101

MENDES, B. S. S.; WILLADINO, L. G.; CUNHA, P. C. da; OLIVEIRA FILHO, R. A. de; CAMARA, T. R. Mecanismo fisiológicos e bioquímicos do abacaxi ornamental sob estresse salino. Revista Caatinga, v. 24, n. 3, p. 71-77, 2011.

SÁ, F. V. da S.; GHEYI, H. R.; LIMA, G. S. de; PAIVA, E. P. de; LACERDA, C. F.; FERNANDES, P. D. Saline water, nitrogen and phosphorus on water relations and physiological aspects of West Indian cherry. Comunicata Scientiae, v. 9, n. 3, p. 430437, 2018b. https://doi.org/10.14295/cs.v9i3.2781

SÁ, F. V. da S.; GHEYI, H. R.; LIMA, G. S. de; PAIVA, E. P. de; MOREIRA, R. C. L.; SILVA, L. de A. Water salinity, nitrogen and phosphorus on photochemical efficiency and growth of West Indian cherry. Revista Brasileira de Engenharia Agrícola e Ambiental, v. 22, n. 3, p. 158-163, 2018a. http://dx.doi.org/10.1590/1807-1929/agriambi.v22n3p158-163

SÁ, F. V. da S.; GHEYI, H. R.; LIMA, G. S. de; PAIVA, E. P. de; SILVA, L. de A.; MOREIRA, R. C. L. et al. Ecophysiology of West Indian cherry irrigated with saline water under phosphorus and nitrogen doses. Bioscience Journal, v. 35, n. 1, p.211-221. 2019. http://dx.doi.org/10.14393/BJ-v35n1a2019-41742

SCHOLANDER, P. F.; HAMMEL, H. T.; HEMMINGSEN, E. A.; BRADSTREET, E. D. Hydrostatic pressure and osmotic potentials in leaves of mangroves and some other plants. Proceedings of the National Academy of Science, v. 52, n. 1, p. 119-125, 1965.

SILVA, A. R. A.; BEZERRA, F. M. L.; LACERDA, C. F. de; SOUSA, C. H. C. de; CHAGAS, K. L. Pigmentos fotossintéticos e potencial hídrico foliar em plantas jovens de coqueiro sob estresses hídrico e salino. RevistaAgro@mbiente On-line, v. 10, n. 4, p. 317-325, 2016. http://dx.doi.org/10.18227/1982-8470ragro.v10i4.3650

SOUSA, J. R. M. de; GHEYI, H. R.; BRITO, M. E. B.; SILVA, F. de A. F. D. da; LIMA, G. S. de. Dano na membrana celular e pigmentos clorofilianos de citros sob águas salinas e adubação nitrogenada. Irriga, v. 22, n. 2, p. 353-368, 2017. https://doi.org/10.15809/irriga.2017v22n2p353-368

TAIZ, L.; ZEIGER, E.; MOLLER, I. M.; MURPHY, A. Fisiologia e desenvolvimento vegetal. 6. ed. Porto Alegre: Artmed, 2017. 858p.

WEATHERLEY, P. E. Studies in the water relations of the cotton plant. I. The field measurement of water deficits in leaves. New Phytologist, v. 49, n. 1, p. 81-97, 1950. 


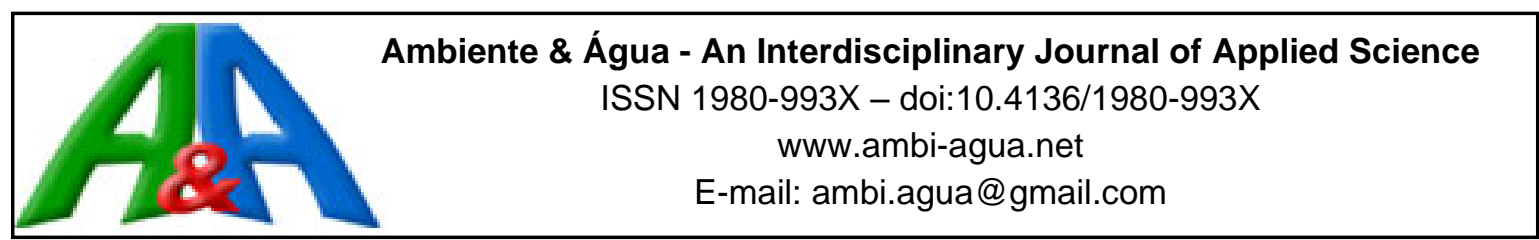

\title{
Outflow adjustment coefficient for the design of storage facilities using the rain envelope method applied to Brazilian state capitals
}

\author{
ARTICLES doi:10.4136/ambi-agua.2707
}

Received: 11 Feb. 2021; Accepted: 04 Oct. 2021

\begin{abstract}
Diego Marangoni Santos ${ }^{\circledR}$; Joel Avruch Goldenfum ${ }^{i}$; Fernando Dornelles*iD
Instituto de Pesquisas Hidráulicas. Departamento de Hidromecânica e Hidrologia. Universidade Federal do Rio Grande do Sul (UFRGS), Avenida Bento Gonçalves, n 9500, Caixa Postal 15029, CEP: 91501-970, Porto Alegre, RS, Brazil.E-mail: diegomarangoni@hotmail.com, joel@iph.ufrgs.br

*Corresponding author. E-mail: fernando.dornelles@ufrgs.br
\end{abstract}

\begin{abstract}
Detention devices are often used as alternative measures for stormwater control. The Envelope Curve Method is widely used in Brazil to estimate detention device volumes. This method estimates the storage volume based on inlet and outlet balance, where the inlet is obtained by the Rational Method and the outlet by orifice bottom discharge. Usually, the outlet flow is adopted as a constant and equivalent to the maximum allowed, and this procedure can cause reservoir undersizing. This paper evaluates detention control measures' hydraulic behavior for the Envelope Curve Method and proposes the inclusion of an outflow adjustment coefficient $\left(\mathrm{C}_{\text {out }}\right)$, seeking to compensate for the adoption of constant outlet flow simplification. Values for this coefficient were estimated for several Brazilian state capitals, ranging from 0.62 up to 0.65 . The undersizing hypothesis due to the adoption of constant outlet flow was confirmed, as the simulations showed the need for an increase between $8.4 \%$ to $16.8 \%$ in the device size. This undersizing may be compensated for by applying the outflow adjustment coefficient $\left(\mathrm{C}_{\text {out }}\right)$.
\end{abstract}

Keywords: adjustment coefficient, detention facilities, envelope curve, hydrologic design outflow adjustment coefficient.

\section{Coeficiente de ajuste para o dimensionamento de reservatórios pelo método da curva envelope aplicado a capitais estaduais brasileiras}

\section{RESUMO}

Reservatório de detenção são usualmente empregados para realizar o controle de escoamento pluviais. Um dos métodos de dimensionamento de dispositivos de reservação, muito utilizado no Brasil, é o método da curva envelope. Este método estima o volume necessário de armazenamento por meio do balanço dos volumes de entrada e saída, sendo a entrada com base no Método Racional e a saída por orifício de descarga de fundo. Neste método é adotada uma vazão constante de saída igual à máxima permitida, o que pode causar subdimensionamentos. Este artigo teve como objetivo avaliar o comportamento hidráulico de medidas de controle de detenção dimensionadas pelo Método da Curva Envelope, e propor uma alteração nesta metodologia, com a criação de um coeficiente de ajuste da vazão de saída $\left(\mathrm{C}_{\text {out }}\right)$, visando compensar a simplificação de utilizar a vazão efluente constante. Valores para esse coeficiente foram estimados para diversas capitais brasileiras, variando de 0.62 a 0.65 . A 
hipótese de subdimensionamento devido à adoção de uma vazão constante foi confirmada, pois as simulações mostraram a necessicidade de um aumento entre $8.8 \%$ a $16.8 \%$ no tamanho do dispositivo de controle. Uma compensação para esse problema pode ser obtida aplicando o coeficiente de redução da vazão de saída $\left(\mathrm{C}_{\text {out }}\right)$.

Palavras-chave: coeficiente de ajuste, curva envelope, dimensionamento hidrológico, dispositivos de detenção.

\section{INTRODUCTION}

The urbanization process modifies the physical characteristics of the watershed, increasing impervious surfaces and changing the hydrologic cycle. These changes cause an increase in stormwater runoff volume and peak flow and decrease flow time (Chen et al., 2015; Guan et al., 2016; Zhou, 2014).

Their impacts on the hydrologic cycle result in an increase in the frequency of water-related disasters such as floods and, as a consequence, there are stormwater control measures (SCMs) that seek to compensate for the effects of urban occupation. Among the SCMs adopted, storage measures stand out, which restrict the inlet hydrograph, providing temporary storage of the runoff. Several municipalities in Brazil, such as Porto Alegre, Brasília, and São José do Rio Preto, have adopted these measures for new construction in order to control hydrological impacts, with the requirement that reservoir construction include an outflow restriction of flow to the public drainage system (Brasília, 2018; Porto Alegre, 2014; São José do Rio Preto, 2008)

There are several methods for design or preliminary design of detention facilities, among them the rain envelope method, which is often used in Brazil.

Butler et al. (2018) presents the envelope method as a preliminary sizing of reservoirs, and Azzout et al. (1994) presents it as a simplified sizing method. Baptista et al. (2011) and Miguez et al. (2015) call the methodology the rainfall method of envelope curves, and present it as a simplified form of structure design. Some examples of use from the rain envelope method can be seen in Lucas et al. (2013), in the design of a filter-swale-trench system; Angelini Sobrinha et al. (2012), in the design of an infiltration well; and in Cadore et al. (2016), for bioretention areas. In addition, Silveira and Goldenfum (2007) presented a generalized methodology for preliminary sizing of SCMs using the envelope curve method.

The envelope curve method is characterized as being simple and straightforward, with several simplifications, among which we highlight the adoption of the outflow rate as a constant equal to the rate of outflow when the storage facility is full and the outlet is under maximum head, which may cause under-dimensioning in the structures. These simplifications are the core of criticism of adopting the sizing results of this method needing further sizing checks. On the other hand, there is no approach to redress the undersizing effect on the results by envelope curve use.

This article evaluates the hydraulic behavior of stormwater control detention measures designed by the rain envelope method, proposes a change in this methodology with the creation of an outflow adjustment coefficient $\left(\mathrm{C}_{\text {out }}\right)$ in order to correct the underestimation caused by using the outflow rate as a constant value.

\section{MATERIAL AND METHODS}

\subsection{Rain envelope method or rainfall method}

The rain envelope method or rainfall method, presented by Urbonas and Stahre (1993), is a simple method for determination of detention volume based on mass balance in a detention facility. It uses curves of cumulative runoff volume and cumulative volume of outflow at 
different durations of rainfalls, where the largest difference between the two curves expresses the storage volume. The method does not consider the time of concentration of the basin and uses the rational method to estimate the flow contribution to the detention facility, being indicated to areas smaller than around 80 ha (ASCE, 2017).

The first step in this method is to calculate the cumulative runoff volume for a range of storm durations. This is done by incrementally increasing the storm duration and, for each duration, the volume is calculated from Equation 1, using the runoff coefficient $(\mathrm{C})$, the ration between the runoff and the respective precipitation, and the average rainfall intensity determined by an intensity-duration-frequency (IDF) curve.

$$
V_{\text {in }}=\frac{\text { C.I.A.t }}{3600 \cdot 1000}
$$

Where Vin = cumulative runoff volume $\left(\mathrm{m}^{3}\right) ; C=$ runoff coefficient (varies from 0 to 1 ); $I=$ average rainfall intensity $\left(\mathrm{mm} \cdot \mathrm{h}^{-1}\right) ; A=$ tributary area $\left(\mathrm{m}^{2}\right) ; t=$ duration $(\mathrm{s})$.

The volume of the outflow curve varies according to design characteristics. For detention facilities with nozzles or orifices as outlets, the outflow can be determined, considering free discharge at atmospheric pressure, using Equation 2. The volume of outflow is commonly estimated by Equation 3, using the simplification that the structure empties at a constant rate equal to the maximum possible outlet outflow (considering the device full and outlet under maximum head). As already shown by Urbonas and Stahre (1993), with the exception of special flow regulators the outflow is not constant and varies with the depth of water as the structure fills and empties.

$$
\begin{aligned}
& Q_{\text {out }}=C_{d} \cdot A_{o} \cdot \sqrt{2 \cdot g \cdot h} \\
& V_{\text {out }}=Q_{\text {out }} \cdot t
\end{aligned}
$$

Where: $C d=$ discharge coefficient ; $A o=$ area of the opening $\left(\mathrm{m}^{2}\right) ; g=$ gravitational acceleration $\left(\mathrm{m} . \mathrm{s}^{-2}\right) ; h=$ effective head seen by the orifice $(\mathrm{m})$; Vout $=$ cumulative outflow volume $\left(\mathrm{m}^{3}\right) ;$ Qout $=$ maximum outflow rate $\left(\mathrm{m}^{3} \cdot \mathrm{s}^{-1}\right) ; t=$ duration $(\mathrm{s})$.

To provide the controlled release of flows when the detention facility's water exceeds its storage volume, commonly spillways are used. The discharge flow of the spillway can be determined by Equation 4.

$$
Q_{s}=C_{s} \cdot L \cdot h^{\frac{3}{2}}
$$

Where: $Q \mathrm{~s}=$ spillway flow $\left(\mathrm{m}^{3} \cdot \mathrm{s}^{-1}\right) ; C \mathrm{~s}=$ spillway discharge coefficient; $L=$ spillway width $(\mathrm{m}) ; h=$ head over the spillway crest (m).

The storage volume obtained by the method is the largest difference between the two curves obtained by Equations 1 and 3, defined by Equation 5 and illustrated in Figure 1.

$$
V r=\max \left(V_{\text {in }}-V_{\text {out }}\right)
$$

Where: $V r=$ storage volume $\left(\mathrm{m}^{3}\right)$.

The simplification of using, during all rainfall periods, the outflow rate equal to the maximum possible outlet flow causes a cumulative outflow volume curve with values greater than what they are supposed to be, resulting in lower volumes of reservation, reducing the safety of the project. 


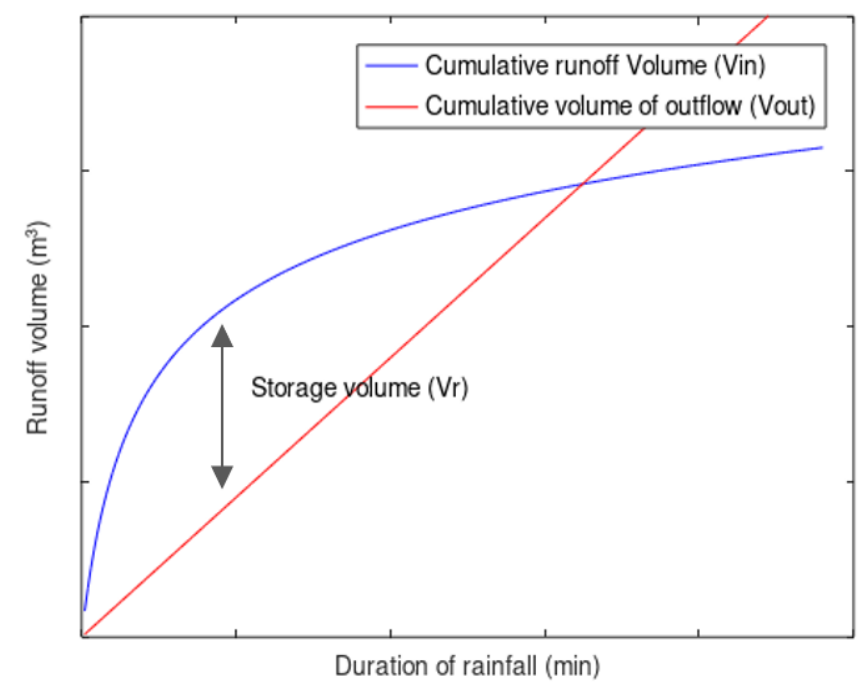

Figure 1. Storage volume using the rain envelope method.

\subsection{Curve envelope method verification}

In order to identify the impact of the simplification of the reservoirs designed by the envelope method, the hydraulic behavior of the structure storage volume obtained by the envelope curve method was simulated using one of the most traditional models to simulate reservoir routing; it was developed by Puls (Nascimento and Baptista, 2009).

The IDF curve used to obtain the rainfall used for the envelope curve and Puls method was the recommended IDF curve for the $8^{\text {th }}$ District of Porto Alegre (Bemfica et al., 2000) with a return period of 10 years (Equation 6).

$I=\frac{1297.9 T_{R}^{0.171}}{(r d+11.6)^{0.85}}$ (min).

Where $I=$ average rainfall intensity $\left(\mathrm{mm} \cdot \mathrm{h}^{-1}\right) ; T_{R}=$ return period (years); $r d=$ rain duration

For the envelope curve method, the characteristics of the tributary site were: tributary area (A) of $1000 \mathrm{~m}^{2}$ and runoff coefficient (C) of 0.9. The outlet was considered as an orifice with diameter of $25 \mathrm{~mm}$, and the input for the outflow rate was considered a constant obtained by Equation 3, with a maximum depth of water of $1 \mathrm{~m}$ and a discharge coefficient of 0.94 , according to experimental values found for this outlet diameter and water depth (Drummond, 2014). From this information, with Equation 5, the storage volume was obtained.

These characteristics were chosen for $Q_{\text {out }}$ to be smaller than the Porto Alegre outflow restriction flow to the public drainage system $\left(20.81 . \mathrm{s}^{-1} \cdot \mathrm{ha}^{-1}\right.$ or $2.081 . \mathrm{s}^{-1}$ for this tributary area) (Porto Alegre, 2014).

For the Puls method, the same IDF curve was used, with a time distribution obtained by the alternating blocks hyetograph method (Chow et al., 1988), centralized peak and rain discretization of 1 minute in order to obtain a hyetograph.

The inflow hydrograph of the reservoir was determined from the hyetograph multiplied by the same values of runoff coefficient and tributary area for each time interval of the hyetograph, thus obtaining the inflow hydrograph. The outflow rate was defined by Equation 3, with the same characteristics of outlet for envelope curve, but considering the outflow rate variable in time, function of water depth. In case of exceeding storage volume during the simulation, a spillway was designed to remove excess water, with the discharge flow obtained by Equation 
4, with $C_{s}$ of 1.77 .

2.3. Reservoir hydraulic behavior with traditional envelope curve method storage volume

For the rain and tributary characteristics described in the method verification, the envelope curve is shown in Figure 2. The constant outflow rate of the method $\left(\mathrm{Q}_{\text {lim }}\right)$ resulted in $2.041 . \mathrm{s}^{-1}$ and the storage volume was $40.2 \mathrm{~m}^{3}$, occurring with a rainfall duration of 102 minutes.

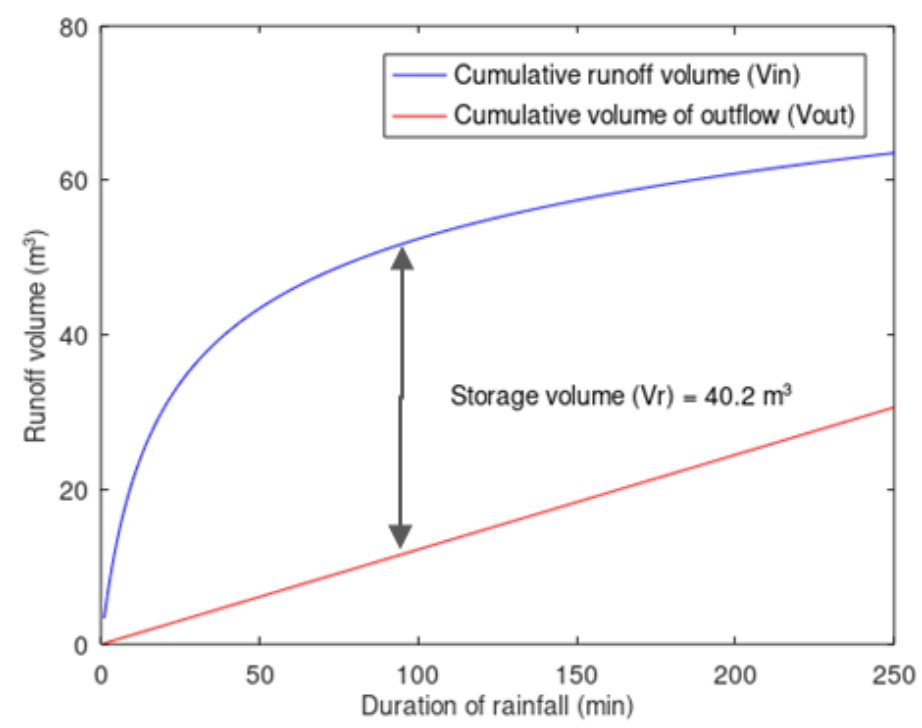

Figure 2. Envelope curve method for Porto Alegre with: $\mathrm{C}=0.9 ; \mathrm{Q}_{\lim }=2.041 . \mathrm{s}^{-1} ; \mathrm{A}=1.000 \mathrm{~m}^{2}$.

Figure 3 presents the reservoir outflow hydrographs for the Puls method, with simulations for rainfall durations from 10 to 120 minutes for Porto Alegre by the alternating blocks method. The storage volume of the reservoirs used in all simulations were the ones found using the envelope method, $40.2 \mathrm{~m}^{3}$. The results show that the design volume was not adequate to withstand the runoff volumes of rainfall durations above 60 minutes; therefore, the 102 minutes of rainfall duration, duration from the envelope method, also had water depth above $1 \mathrm{~m}$, causing the spillway to remove the excess water and the outflow rate to peak above $2.041 . \mathrm{s}^{-1}$.

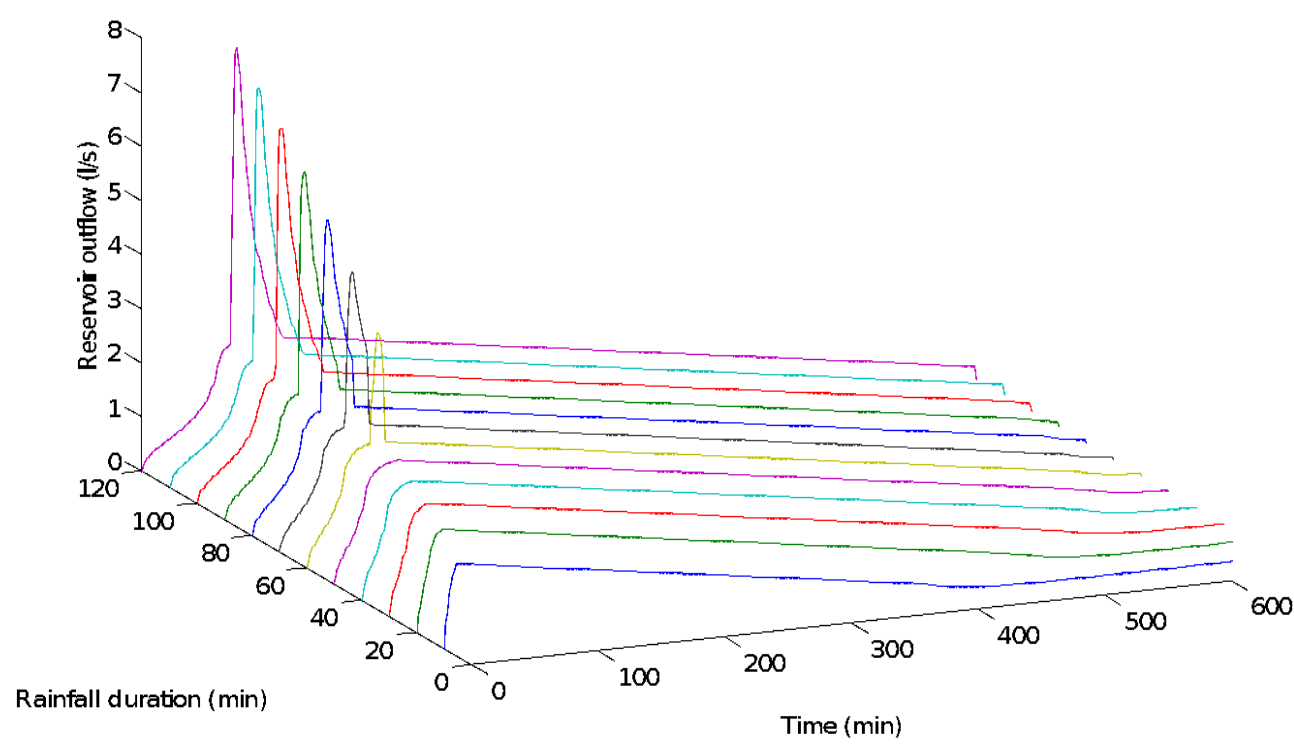

Figure 3. Verification reservoir outflow hydrographs by Puls simulation for the traditional envelope curve sizing method. 
The difference between the outflow estimated by the verification method (Puls) and the constant outflow for the envelope method is shown in Figure 4.a, simulation of rainfall duration of 102 minutes for Porto Alegre, where the green area of the figure represents the outflow volume difference between the methods.

a)

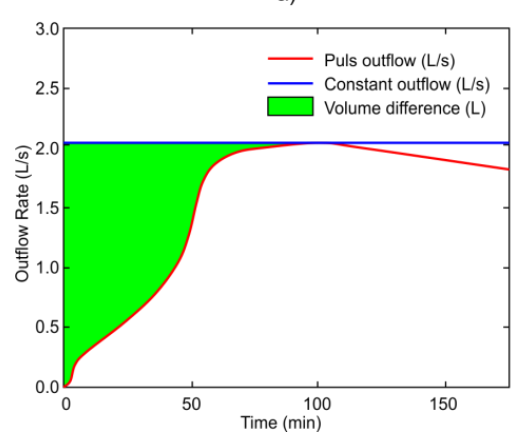

b)

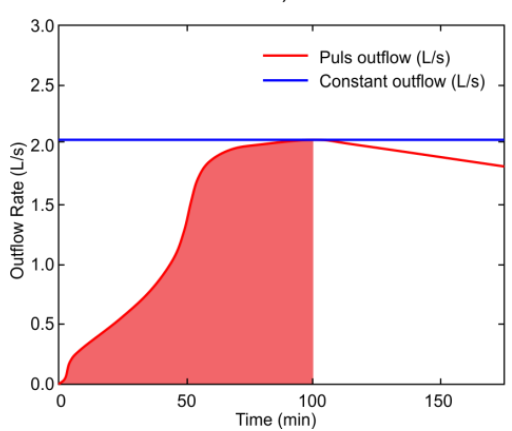

c)

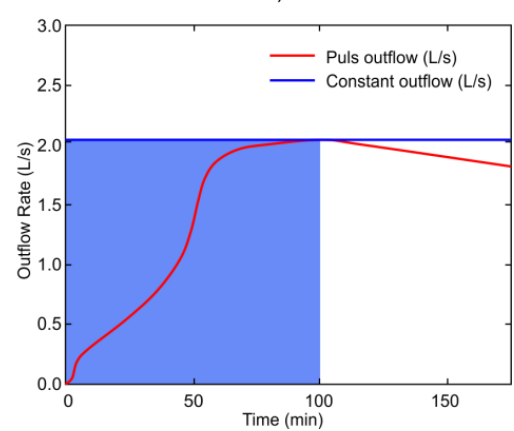

Figure 4. Outflow comparisons of Envelope and Puls methods: a) volume difference between Puls and Envelope outflows; b) outflow volumes by Puls simulation; c) outflow volumes by Envelope.

\subsection{Proposed methodology to compensate for the constant outflow simplification}

An outflow adjustment coefficient $\left(\mathrm{C}_{\text {out }}\right)$ was created in order to compensate for the simplification of constant outflow, adopting the ratio between the accumulated volume obtained by the Puls methodology (an area under the red line in Figure 4.b up to reach the blue line for constant outflow) and the constant outflow (a rectangular area in Figure 4.c under blue line until to intercept the red line). The coefficient was obtained using the same rainfall duration as found for the storage volume in the envelope curve, called "critical duration time" (Tcrit), and gradually increasing the storage volume until the minimum detention volume that would not cause the water depths above the maximum, i.e., spillway unused (Equation 7).

$C_{\text {out }}=\frac{V_{\text {Puls }}}{V_{\text {out }}}$

Where $C_{\text {out }}=$ outflow adjustment coefficient; $V_{\text {Puls }}=$ cumulative outflow volume by Puls method $\left(\mathrm{m}^{3}\right)$.

From the $\mathrm{C}_{\text {out }}$, the incremental volume, denominated as $V_{i}$, is determined by Equation 8 . The incremental volume is then added to the storage volume determined by the envelope curve method, resulting in the adjusted storage volume (Equation 9).

$$
\begin{aligned}
& V_{i}=\left(1-C_{\text {out }}\right) Q_{\text {lim }} \cdot t \\
& V_{R A}=\max \left(V_{\text {in }}-V_{\text {out }}\right)+V_{i}
\end{aligned}
$$

Where $V_{i}=$ incremental volume $\left(\mathrm{m}^{3}\right) ; V_{\mathrm{RA}}=$ adjusted storage volume $\left(\mathrm{m}^{3}\right)$.

\subsection{Sensitivity of $\mathbf{C}_{\text {out }}$ to input parameters}

The sensitivity of $\mathrm{C}_{\text {out }}$ was evaluated by simulating different runoff coefficients and sizes of orifices as outlets, modifying the inflow and outflow of the methods. The same methodology of the previous verification was used. The sensitivity of $\mathrm{C}_{\text {out }}$ as a function of the Runoff coefficient $\mathrm{C}$ and $\mathrm{Q}_{\mathrm{lim}}$, constant outflow as a function of orifice diameter (D), for a return period of 10 years is shown in Table 1 . 
Table 1. $\mathrm{C}_{\text {out }}$ sensitivity for period return of 10 years.

\begin{tabular}{cccc}
\hline \multirow{2}{*}{ Qlim $(\mathrm{D})$} & \multicolumn{3}{c}{ Runoff Coefficient $(\mathrm{C})$} \\
\cline { 2 - 4 } & 0.2 & 0.6 & 1.0 \\
\hline $1.31 \mathrm{l} / \mathrm{s}(20 \mathrm{~mm})$ & 0.66 & 0.64 & 0.63 \\
$8.18 \mathrm{1} / \mathrm{s}(50 \mathrm{~mm})$ & 0.82 & 0.69 & 0.68 \\
\hline
\end{tabular}

The value of $\mathrm{C}$ coefficient varied from 0.2 to 1.0 , and the maximum flow capacity from $1.311 . \mathrm{s}^{-1}$ to $8.181 . \mathrm{s}^{-1}$, respectively, for commercial diameters of orifices of $20 \mathrm{~mm}$ and $50 \mathrm{~mm}$.

The results showed that the value of the $C_{\text {out }}$ increases when the value of the $C$ reduces, and that $\mathrm{C}_{\text {out }}$ is also higher when the diameter of the orifice is higher. Therefore, the combination of higher $\mathrm{C}$ and smaller diameter results in a smaller coefficient, which is the less favorable scenario, since the smaller the $\mathrm{C}_{\text {out }}$ the greater the incremental volume $V_{i}$.

In order to observe the impact of a higher period return on the coefficient, the process was repeated for a period return of 50 years. The coefficients found are shown in Table 2 and were similar to those with a period return of 10 years.

Table 2. $\mathrm{C}_{\text {out }}$ sensitivity for return period of 50 years.

\begin{tabular}{cccc}
\hline \multirow{2}{*}{$Q_{\lim }($ Diameter$)$} & \multicolumn{3}{c}{ Runoff Coefficient $(\mathrm{C})$} \\
\cline { 2 - 4 } & 0.2 & 0.6 & 1.0 \\
\hline $1.31 \mathrm{l} / \mathrm{s}(20 \mathrm{~mm})$ & 0.66 & 0.63 & 0.62 \\
$8.18 \mathrm{l} / \mathrm{s}(50 \mathrm{~mm})$ & 0.77 & 0.68 & 0.66 \\
\hline
\end{tabular}

\section{RESULTS}

\subsection{Cout applied to Brazilian state capitals}

According to the results of Tables 1 and 2, the least favorable condition for the coefficient Cout, the smallest value, occurs with a higher $\mathrm{C}$ and smaller orifice diameter. Cout values were determined for several Brazilian state capitals, using Equation 7 with the same methodology previously described. The adopted conditions were the same as used in the curve envelope method verification: coefficient $C$ equal to 0.9 ; outlet considered as an orifice as $25 \mathrm{~mm}$ of diameter; discharge coefficient of 0.94; maximum water depth of $1 \mathrm{~m}$; tributary area of $1000 \mathrm{~m}^{2}$. The rain parameters for each state capital are presented in Table 3, following the format of Equation 10. Figure 5 shows the studied cities locations in Brazil.

$$
I=\frac{a \cdot T_{R}{ }^{b}}{(r d+c)^{d}}
$$

Where: $a, b, c$ e $d$ are adjusted parameters for each city.

Table 4 presents the values of the $\mathrm{C}_{\text {out }}$ for period returns of 10 and 50 years, showing the dispersion between them for the different regions of Brazil. The $\mathrm{C}_{\text {out }}$ values presented in the table were the coefficients obtained for the rainfall duration equal to the critical time $T_{\text {crit }}$.

Even though there is a great variability in the pluviometric characteristics of the Brazilian state capitals presented, there is only a small variation in the values of $\mathrm{C}_{\text {out }}$. Table 5 presents the storage volume $(\mathrm{Vr})$ needed for each city for a return period of 10 years using the envelope curve method and the adjusted storage volume $\left(V_{R A}\right)$ when considering the coefficient $\mathrm{C}_{\text {out. }}$.

The results showed a $\mathrm{C}_{\text {out }}$ coefficient ranging from 0.62 to 0.65 and an increase in storage 
volume considering the proposed methodology from $8.4 \%$ to $16.8 \%$.

Table 3. IDF curves parameters for several Brazilians state capitals.

\begin{tabular}{ccccc}
\hline \multirow{2}{*}{ City } & \multicolumn{4}{c}{ Parameters } \\
\cline { 2 - 5 } & $\mathrm{a}$ & $\mathrm{b}$ & $\mathrm{c}$ & $\mathrm{d}$ \\
\hline Aracaju $^{1}$ & 834.2 & 0.179 & 15 & 0.726 \\
Belém $^{1}$ & 1085.5 & 0.156 & 12 & 0.758 \\
Belo Horizonte $^{2}$ & 1447.9 & 0.100 & 20 & 0.840 \\
Brasília $^{3}$ & 1574.7 & 0.207 & 8 & 0.884 \\
Cuiabá $^{4}$ & 1016.5 & 0.133 & 7.5 & 0.739 \\
Curitiba $^{5}$ & 5726.6 & 0.159 & 41 & 1.041 \\
Florianópolis $^{1}$ & 1754.2 & 0.187 & 36 & 0.823 \\
Fortaleza $^{7}$ & 2345.3 & 0.173 & 28.3 & 0.904 \\
Goiânia $^{8}$ & 920.5 & 0.142 & 12 & 0.760 \\
Manaus $^{1}$ & 1136.5 & 0.158 & 10 & 0.764 \\
Porto Alegre $^{9}$ & 1297.9 & 0.171 & 11.6 & 0.850 \\
Porto Velho $^{1}$ & 1181.4 & 0.159 & 11 & 0.757 \\
Rio Branco $^{1}$ & 1419.3 & 0.162 & 18 & 0.795 \\
Rio de Janeiro $^{10}$ & 1239.0 & 0.150 & 20 & 0.740 \\
São Luiz $^{1}$ & 1519.4 & 0.161 & 28 & 0.777 \\
São Paulo $^{11}$ & 3462.6 & 0.172 & 22 & 1.025 \\
Teresina $^{1}$ & 1248.9 & 0.177 & 10 & 0.769
\end{tabular}

${ }^{1}$ Fragoso Jr. (2004); ${ }^{2}$ Zahed Filho and Marcellini (1995); ${ }^{3}$ Distrito Federal (2009); ${ }^{4}$ Castro et al. (2011); ${ }^{5}$ Fendrich (2003); ${ }^{7}$ Silva et al. (2013); ${ }^{8}$ Oliveira et al. (2003); ${ }^{9}$ Bemfica et al. (2000); ${ }^{10}$ Bertoni and Tucci (1993); ${ }^{11}$ Wilken (1978).

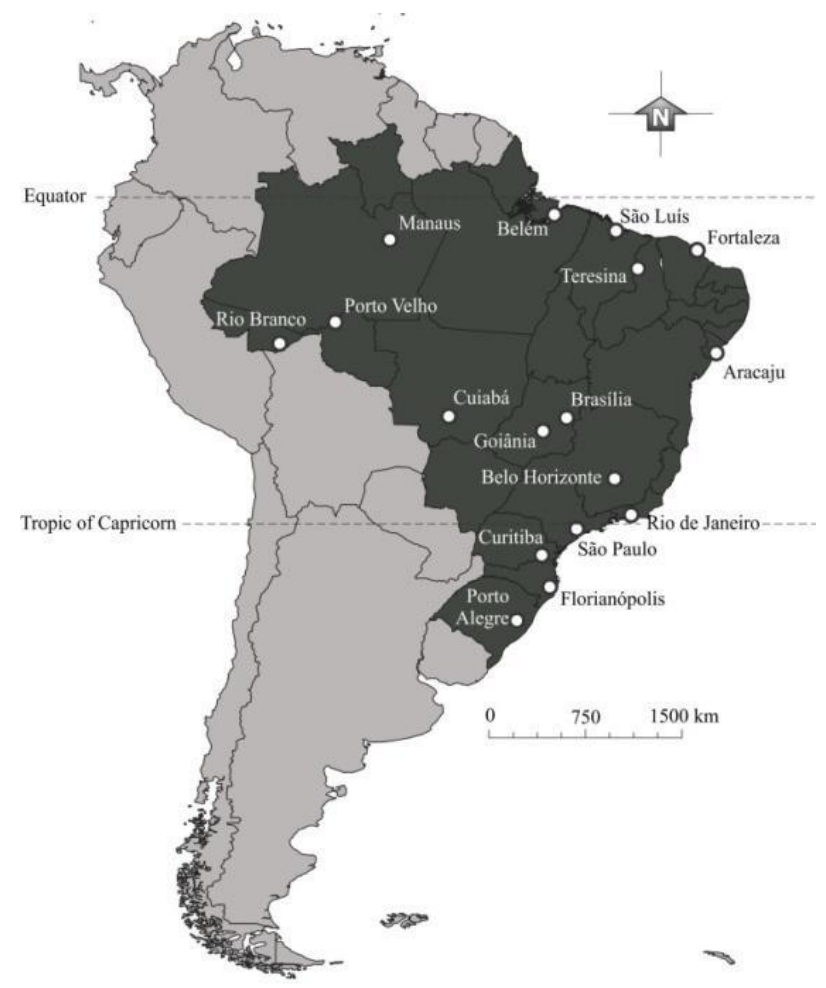

Figure 5. Spatial location of the cities used in the study. 
The results are similar to those found by Guo (1999), 0.64 to 0.75 for an outflow reduction coefficient and he also concludes that not using the adjustment factor can result in approximately $20 \%$ underestimation of detention volume.

Table 4. Values of the $\mathrm{C}_{\text {out }}$ for period returns of 10 and 50 years and several Brazilian Capitals.

\begin{tabular}{ccc}
\hline \multirow{2}{*}{ City } & $\mathrm{T}_{\mathrm{R}}-10$ years & $\mathrm{T}_{\mathrm{R}}-50$ years \\
\cline { 2 - 3 } & $\mathrm{C}_{\text {out }}$ & $\mathrm{C}_{\text {out }}$ \\
\hline Aracaju & 0.65 & 0.65 \\
Belém & 0.64 & 0.64 \\
Belo Horizonte & 0.65 & 0.64 \\
Brasília & 0.62 & 0.62 \\
Cuiabá & 0.64 & 0.64 \\
Curitiba & 0.64 & 0.63 \\
Florianópolis & 0.65 & 0.64 \\
Fortaleza & 0.64 & 0.63 \\
Goiânia & 0.65 & 0.64 \\
Manaus & 0.64 & 0.64 \\
Porto Alegre & 0.64 & 0.63 \\
Porto Velho & 0.64 & 0.64 \\
Rio Branco & 0.64 & 0.64 \\
Rio de Janeiro & 0.65 & 0.65 \\
São Luiz & 0.65 & 0.64 \\
São Paulo & 0.64 & 0.63 \\
Teresina & 0.64 & 0.63 \\
\hline
\end{tabular}

Table 5. Storage Volume $(V r)$ and Adjusted storage volume $\left(V_{R A}\right)$.

\begin{tabular}{cccc}
\hline City & $\mathrm{Vr}\left(\mathrm{m}^{3}\right)$ & $\mathrm{V}_{\mathrm{RA}}\left(\mathrm{m}^{3}\right)$ & $\%$ \\
\hline Aracaju & 52.0 & 60.8 & $16.8 \%$ \\
Belém & 56.0 & 64.1 & $14.6 \%$ \\
Belo Horizonte & 37.0 & 42.0 & $13.7 \%$ \\
Brasília & 48.4 & 52.7 & $8.8 \%$ \\
Cuiabá & 56.0 & 64.2 & $14.6 \%$ \\
Curitiba & 60.3 & 66.1 & $9.5 \%$ \\
Florianópolis & 65.8 & 75.3 & $14.4 \%$ \\
Fortaleza & 54.1 & 60.4 & $11.7 \%$ \\
Goiânia & 41.8 & 48.0 & $14.9 \%$ \\
Manaus & 58.0 & 66.1 & $13.9 \%$ \\
Porto Alegre & 40.2 & 44.7 & $11.2 \%$ \\
Porto Velho & 64.4 & 73.5 & $14.1 \%$ \\
Rio Branco & 61.1 & 69.4 & $13.6 \%$ \\
Rio de Janeiro & 73.6 & 85.3 & $15.8 \%$ \\
São Luiz & 73.5 & 84.5 & $15.0 \%$ \\
São Paulo & 44.1 & 47.8 & $8.4 \%$ \\
Teresina & 67.7 & 76.6 & $13.1 \%$ \\
\hline
\end{tabular}

\section{DISCUSSION AND CONCLUSIONS}

This paper evaluated the performance of storage facilities designed by the envelope curve 
method and showed undersizing in the storage volume when considering a simplification of the outflow rate as a constant value equal to the maximum discharge capacity of the outlet. The hydraulic verification results showed that the reservoirs were insufficient to store the inflow volumes. Thus, an outflow adjustment coefficient $\mathrm{C}_{\text {out }}$ was proposed in order to compensate for the considered simplification.

The application of the proposed methodology was applied to several Brazilian state capitals and indicated there is little variation in the value of $\mathrm{C}_{\text {out }}$, ranging from 0.62 to 0.65 , even though there is great variability in the pluviometric characteristics of these cities. The results also showed that, for the studied cities, the adjusted methodology caused an increase in the storage volume from $8.4 \%$ to $16.8 \%$.

Finally, the parameters adopted (lot area; runoff coefficient; return period; orifice diameter; IDF of 17 Brazilian States Capital) for the simulations were the most frequent values for the urban lots, so this criteria can indeed be representative for several areas and even for the whole country after analysis of results for Cout, as it varies only within a narrow range.

\section{REFERENCES}

ANGELINI SOBRINHA, L. et al. Monitoramento e modelagem de um poço de infiltração de águas pluviais em escala real e com filtro na tampa. 2012. 149 f. Dissertação (Mestrado em Ciências Exatas e da Terra) - Universidade Federal de São Carlos, São Carlos, 2012.

ASCE. Standard guidelines for the design, installation, and operation and maintenance of urban stormwater systems. Reston, 2017.

AZZOUT, Y.; BARRAUD, S.; CRES, F. N.; ALFAKIH, E. Techniques alternatives en assainissement pluvial. Paris: Lavoisier, 1994. 372 p.

BAPTISTA, M. B.; DE OLIVEIRA NASCIMENTO, N.; BARRAUD, S. Técnicas compensatórias em drenagem urbana. Porto Alegre: ABRH, 2011.

BEMFICA, D. C.; GOLDENFUM, J. A.; SILVEIRA, A. L. L. da. Análise da aplicabilidade de padrões de chuva de projeto a Porto Alegre. Revista Brasileira de Recursos Hídricos, v. 5 , n. 4, 2000.

BERTONI, J. M.; TUCCI, C. E. M. Precipitação. In: TUCCI, C. E. M. Hidrologia Ciência e Aplicação. Porto Alegre: Editora da UFRGS, 1993. Cap. 5.

BRASÍLIA. Manual de drenagem e manejo das águas pluviais urbanas do Distrito Federal. Brasília, DF: Adasa; Unesco, 2018.

BUTLER, D.; DIGMAN, C.; MAKROPOULOS, C.; DAVIES, J.W. Urban drainage. Boca Raton: CRC Press, 2018.

CADORE, R. C. et al. Critérios de dimensionamento de biorretenções. 2016. 116 f. Dissertação (Mestrado em Engenharia Civil) - Universidade Federal de Santa Maria, Santa Maria, 2016.

CASTRO, A. L. P.; SILVA, C. N. P.; SILVEIRA, A. Curvas Intensidade-Duração-Frequência das precipitações extremas para o município de Cuiabá (MT). Ambiência, v. 7, n. 2, p. $305-315,2011$.

CHEN, Y. et al. Urban flood risk warning under rapid urbanization. Environmental Research, v. 139, p. 3-10, 2015. https://doi.org/10.1016/j.envres.2015.02.028 
CHOW, V. T.; MAIDMENT, D.R.; MAYS, L.W. Applied hydrology. Singapore: McgrawHill, 1988.

DISTRITO FEDERAL. Secretaria de Estados de Obras. Plano Diretor de Drenagem Urbana do Distrito Federal: Relatório de Produto 4. Volume 8. Tomo 01/07. Brasília: Concremat Engenharia, 2009.

FENDRICH, R. Chuvas intensas para obras de drenagem no estado do Paraná. 2. ed. Curitiba: Gráfica Vicentina, 2003. 101 p.

FRAGOSO JR., C. R. Regionalização de vazão máxima instantânea com base na precipitação de projeto. Revista eletrônica de Recursos Hídricos, v. 1, n. 1, 2004.

GUAN, M.; SILLANPÄ̈̈, N.; KOIVUSALO, H. Storm runoff response to rainfall pattern, magnitude and urbanization in a developing urban catchment. Hydrological Processes, v. 30, n. 4, p. 543-557, 2016. https://doi.org/10.1002/hyp.10624

GUO, J. C.Y. Detention storage volume for small urban catchments. Journal of water resources planning and management, v. 125, n. 6, p. 380-382, 1999. https://doi.org/10.1061/(ASCE)0733-9496(1999)125:6(380)

LUCAS, A. H.; BARBASSA, A. P.; MORUZZI, R. B. Modelagem de um sistema filtro-valatrincheira de infiltração pelo método de Puls adaptado para calibração de parâmetros. Revista Brasileira de Recursos Hídricos, v. 18, p. 135-236, 2013. http://dx.doi.org/10.21168/rbrh.v18n2.p225-236

MIGUEZ, M.; REZENDE, O.; VERÓL, A. Drenagem urbana: do projeto tradicional à sustentabilidade. São Paulo: Elsevier Brasil, 2015.

NASCIMENTO, N. O.; BAPTISTA, M.B. Técnicas compensatórias em águas pluviais. In: RIGHETTO, A. M. (Coord.). Manejo de áuas pluviais urbanas. Rio de Janeiro: ABES, 2009. Cap. 4, p. 148-197.

OLIVEIRA, L. F. C.; CORTÊS F. C.; WEHR, T. R. BORGES, L. B.; SARMENTO, P. H. L.; GRIEBELER, N. P. Intensidade-duração-frequência de chuvas intensas para localidades no estado de Goiás e Distrito Federal. Engenharia na Agricultura, v. 11, n. 1-4, 2003.

PORTO ALEGRE. Decreto $\mathbf{n}^{\mathbf{0}} \mathbf{1 8 . 6 1 1}$ de 9 de abril de 2014. Regulamenta o controle da drenagem urbana e revoga os itens 4.8.6, 4.8.7 e 4.8.9 do Decreto $\mathrm{n}^{\circ} 14.786$, de 30 de dezembro de 2004 - caderno de encargos do dep - e o decreto $\mathrm{n}^{\mathrm{o}} 15.371$, de 17 de novembro de 2006. Porto Alegre, 2014.

SÃO JOSÉ DO RIO PRETO. Lei no 10.290 de 24 de dezembro de 2008. Cria no município o programa permanente de gestão das águas superficiais (PGAS) da bacia hidrográfica do Rio Preto, e dá outras providências. São José do Rio Preto, 2008.

SILVA, F. O. E.; PALÁCIO JR., F. F.; CAPOS, J. N. B. Equação de chuvas para Fortaleza CE com dados do pluviógrafo da UFC. Revista DAE, n. 192, p. 48-59, 2013.

SILVEIRA, A. L. L da; GOLDENFUM, J. A. Metodologia generalizada para prédimensionamento de dispositivos de controle pluvial na fonte. Revista Brasileira de Recursos Hídricos, v. 12, n. 2, p. 157-168, 2007.

URBONAS, B.; STAHRE, P. Stormwater - Best management practices and detention for water quality, drainage, and CSO management. Prentice Hall, 1993.

WILKEN, P. S. Engenharia de drenagem superficial. São Paulo: CETESB, 1978. 477 p. 
ZAHED FILHO, K.; MARCELLINI, S. S. Precipitações máximas. In: TUCCI, C. E. M.; PORTO, R. L.; BARROS, M. T. L. Drenagem urbana. Porto Alegre: Editora da UFRGS; ABRH, 1995.

ZHOU, Q. A review of sustainable urban drainage systems considering the climate change and urbanization impacts. Water, v. 6, n. 4, p. 976-992, 2014. https://doi.org/10.3390/w6040976 


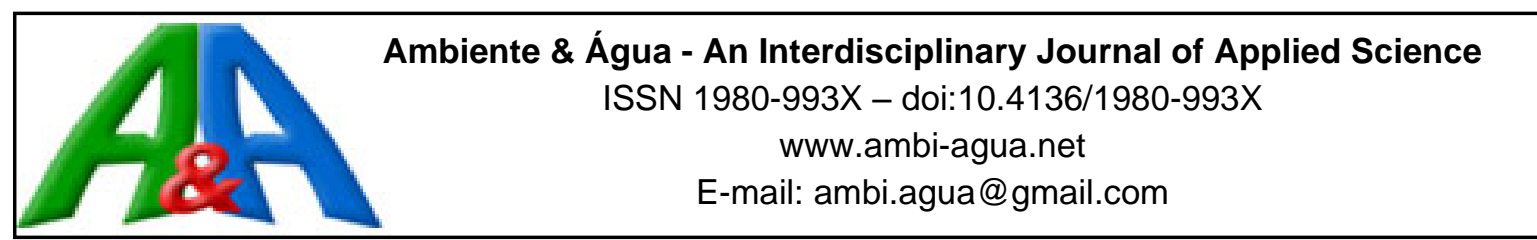

\title{
Hydrological regionalization of streamflows for the Tocantins River Basin in Brazilian Cerrado biome
}

\author{
ARTICLES doi:10.4136/ambi-agua.2716
}

Received: 02 Mar. 2021; Accepted: 08 Oct. 2021

\begin{abstract}
Jéssica Assaid Martins Rodrigues ${ }^{1 * \text { (D) }}$; Marcelo Ribeiro Viola1(i); Carlos Rogério de Mello ${ }^{1}$; Marco Antônio Vieira Morais ${ }^{2}$ id

${ }^{1}$ Departamento de Recursos Hídricos. Universidade Federal de Lavras (UFLA), Caixa Postal 3037, CEP: 37200-900, Lavras, MG, Brazil.E-mail: marcelo.viola@ufla.br, crmello@ufla.br ${ }^{2}$ Instituto Federal de Educação Ciência e Tecnologia de Mato Grosso (IFMT), Rua José Maurício Zampa, s/n, CEP: 78607-899, Barra do Garças, MT, Brazil. E-mail: marco.morais@bag.ifmt.edu.br *Corresponding author. E-mail: je_assaid@yahoo.com.br
\end{abstract}

\begin{abstract}
The Brazilian Cerrado biome is the largest and richest tropical savanna in the world and is among the 25 biodiversity hotspots identified worldwide. However, the lack of adequate hydrological monitoring in this region has led to problems in the management of water resources. In order to provide tools for the adequate management of water resources in the Brazilian Cerrado biome region, this paper develops the regionalization of maximum, mean and minimum streamflows in the Tocantins River Basin $\left(287,405.5 \mathrm{~km}^{2}\right)$, fully located in the Brazilian Cerrado biome. The streamflow records of 32 gauging stations in the Tocantins River Basin are examined using the Mann-Kendall test and the hydrological homogeneity nonparametric index-flood method. One homogeneous region was identified for the estimate of the streamflows $\mathrm{Q}_{\mathrm{ltm}}$ (long-term mean streamflow), Q90\% (streamflow with $90 \%$ of exceeding time), $\mathrm{Q}_{95 \%}$ (streamflow with $95 \%$ of exceeding time) and $\mathrm{Q}_{7,10}$ (minimum annual streamflow over 7 days and return period of 10 years). Two homogeneous regions were identified for maximum annual streamflow estimation and the Generalized Extreme Value distribution is found to describe the distribution of maximus events appropriately within the both regions. Regional models were developed for each streamflow of each region and evaluated by cross-validation. These models can be used for the estimation of maximum, mean and minimum streamflows in ungauged basins within the Tocantins River Basin within the area boundaries identified. Therefore, the results provided in this paper are valuable tools for practicing water-resource managers in the Brazilian Cerrado biome.
\end{abstract}

Keywords: 1-moments, statistical hydrology, water use rights concessions.

\section{Regionalização hidrológica de vazões para a bacia do rio Tocantins no bioma Cerrado brasileiro}

\section{RESUMO}

O bioma Cerrado brasileiro é a maior e mais rica savana tropical do mundo e está entre os 25 hotspots de biodiversidade identificados em todo o mundo. No entanto, o escasso monitoramento hidrológico, recorrente nesta região, tem gerado problemas na gestão dos recursos hídricos. A fim de fornecer ferramentas para a gestão adequada dos recursos hídricos 
na região do bioma Cerrado brasileiro, este trabalho desenvolve a regionalização das vazões máximas, médias e mínimas na bacia do rio Tocantins $\left(287.405,5 \mathrm{~km}^{2}\right)$, totalmente localizada no bioma Cerrado brasileiro. Os registros de vazão de 32 estações fluviométricas na bacia do rio Tocantins foram examinados usando o teste de Mann-Kendall e o método não paramétrico de homogeneidade hidrológica index-flood. Uma região homogênea foi identificada para a estimativa das vazões $Q_{1 t m}$ (vazão média de longo termo), Q90\% (vazão igualada ou excedida em 90\% do tempo), Q95\% (vazão igualada ou excedida em $95 \%$ do tempo) e $\mathrm{Q}_{7,10}$ (vazão mínima anual das médias de 7 dias e tempo de retorno de 10 anos). Duas regiões homogêneas foram identificadas para a estimativa da vazão máxima anual e a distribuição de valor extremo generalizado foi encontrada para descrever a distribuição de eventos máximos apropriadamente dentro de ambas as regiões. Modelos regionais foram desenvolvidos para cada vazão de cada região e avaliados pela validação cruzada. Esses modelos podem ser usados para a estimativa de vazões máximas, médias e mínimas em bacias não medidas dentro da bacia do rio Tocantins, dentro dos limites de área identificados. Portanto, os resultados fornecidos neste artigo são ferramentas valiosas para a prática de gestores de recursos hídricos no bioma Cerrado brasileiro.

Palavras-chave: concessões de direitos de uso de água, hidrologia estatística, momentos 1.

\section{INTRODUCTION}

The volume of fresh water in Brazil accounts for about $12 \%$ of the planet's total, and is one of the largest reserves in the world. However, the natural distribution of fresh water shows great spatial disparity across the territory. Along with this factor, the different types of water use in the basins lead to conflicts for the right to use and uncertainties regarding the risks of flooding. Therefore, for the maintenance of life and environmental preservation, more effective actions are needed in the management of water resources (ANA, 2019a; Charles, 2020).

The Brazilian Cerrado biome is the largest and richest tropical savanna in the world and is among the 25 biodiversity hotspots identified worldwide (Myers et al., 2000; Silva and Bates, 2002). In addition, this region encompasses the recharge area of several aquifers and important rivers in Brazil, being recognized as the "cradle of Brazil's water" (Lima, 2011). However, the lack of adequate hydrological monitoring in this region has led to problems in the management of water resources, which may further compromise the sustainability of this important biome. Thus, improving the knowledge base on streamflow in the Cerrado biome is essential for water management in Brazil and for ensuring water security and economic development (Rodrigues et al., 2021).

The Tocantins River Basin $\left(287,405.5 \mathrm{~km}^{2}\right)$ is a large area of the Cerrado biome, which has been confronting water resource management problems around the expansion of waterusing sectors, such as irrigated agriculture and hydro-energy. Irrigated agriculture is the primary consumer of water in this basin (ANA, 2019b), it presents a demand for the use of water of 44.3\%. In addition, this basin is the third-ranked Brazilian basin in hydroelectric potential (ELETROBRAS, 2016). The TRB covers three Brazilian states: Goiás, Tocantins and Maranhão, which use streamflows that are exceeded 90 and $95 \%$ of the time $\left(\mathrm{Q}_{90 \%}\right.$ and $\mathrm{Q}_{95 \%}$, respectively) as references for granting water use rights.

Hydrological monitoring is the ideal way to determine streamflows in watercourses of interest. However, in countries such as Brazil, whose dimensions are continental, the density of streamflow gauging stations is unsatisfactory, which compromises the estimation of streamflows for water resource management (Melati and Marcuzzo, 2016). According to Pugliesi et al. (2016) the need to understand streamflow behavior is one of the biggest problems that occur in ungauged basins. Another obstacle that occurs mainly in medium- and smallgauged basins is the unavailability of longer time series, which limits the estimation of reliable quantiles (Beskow et al., 2016). 
Rainfall-runoff models are widely used to estimate the streamflow, but calibrating these models in ungauged catchments is a challenge (Pool et al., 2017). Thus, to mitigate the effect of this lack of data, the streamflow regionalization method is an alternative to obtain hydrological information in locations with little or even without datasets. Streamflow regionalization can be applied within a region with similar hydrological behaviour using statistical procedures (Naghettini and Pinto, 2007; Wolff et al., 2014). In this approach, the streamflow statistics at ungauged sites are conditioned by the streamflow statistics at a gauged site, using catchment descriptors as similarity measure (Cupak, 2020). Furthermore, the regionalization models fitted for a given basin should not be applied using inputs out of the boundaries (Silveira and Tucci, 1998). In the TRB, there are no established regionalized models. Therefore, there is a need to develop models which can be applied in the conditions of the Tocantins River Basin.

Maximum, mean and minimum streamflows estimates are essential for water-resource management. Maximum streamflows are essential for hydraulic structure designs, such as dams, bridges, culverts, and urban drainage systems, and for flood risk assessments. Mean streamflow is fundamental for hydropower planning. Minimum streamflows are important as reference for water-use rights concessions, water supply and habitat protection (Beskow et al., 2016).

In order to provide tools for the adequate management of water resources in the Brazilian Cerrado biome region, the objectives of the study were: i) to evaluate the suitability of 10 probability distributions functions using L-moments method and goodness-of-fit test; and, ii) to develop the regionalization of the maximum, mean and minimum streamflows $\left(\mathrm{Q}_{\max }, \mathrm{Q}_{\mathrm{ltm}}\right.$, $\mathrm{Q}_{90 \%}, \mathrm{Q}_{95 \%}$ and $\left.\mathrm{Q}_{7,10}\right)$ for the Tocantins River Basin $\left(287,405.5 \mathrm{~km}^{2}\right)$, fully located in the Brazilian Cerrado biome. The novelty of this study lies in estimation of reliable and robust flows in data scarce regions by using a combination of statistical techniques.

\section{MATERIAL AND METHODS}

\subsection{Study area and streamflow data}

The Tocantins River Basin (TRB) (Figure 1) comprises a drainage area of $287,405.5 \mathrm{~km}^{2}$, is located in the states of Goiás, Tocantins and Maranhão, in the northern region of Brazil, and includes 213 municipalities. This basin is fully inserted in the Cerrado biome and is part of the Tocantins-Araguaia Basin (TARB). The TRB was delimited in the Itaguatins streamflow station (National Water Agency code 23710000).

According to Köppen's climate classification system, the climate of the studied basin is Aw (tropical savanna), with a rainy season in the summer (from November to April) and a dry season in the winter (from May to October) (Kottek et al., 2006; EMBRAPA, 2018).

Twelve hydroelectric plants (Figure 1) are located in TRB and are responsible for a hydropower potential of $4475 \mathrm{MW}$ (ELETROBRAS, 2016). The hydroelectric plants with their respective hydropower potentials and year of start of operation are: Serra da Mesa (1275 MW, 1998); Estreito (1087 MW, 2011); Lajeado (903 MW, 2001); Peixe Angical (452 MW, 2006); Cana Brava (450 MW, 2002); São Salvador (241 MW, 2009); Lagoa Grande (26 MW, 2008); Santa Edwiges II (13 MW, 2006); São Domingos (12 MW, 1991); Dianópolis (6 MW, 1994); Diacal II (5 MW, 1999); and Sobrado (5 MW, 1994). Among these hydroelectric plants, the Serra da Mesa HPP, located at the upper reaches of the Tocantins River, stands out for having the greatest hydropower potential, reservoir and flow regulation capacity (ANEEL, 2018).

Daily streamflow data were obtained from the National Water Agency (ANA) for 32 streamflow gauging stations (Figure 1) with at least 10 years of continuous record (Cassalho et $a l ., 2017)$. Precautions were taken to ensure the natural representation of the streamflows in the study area. Thus, to avoid the regulation effect of dams on the streamflow behavior, only data prior to the start of reservoir operations were used for their downstream stations. In this way, 
13 streamflow gauging stations had their series shortened, while the other 19 streamflow gauging stations had all available data kept. Table 1 shows the characteristics of the streamflow gauging stations and their record lengths used in this study, which ranged from 1955-2017. Figure 1 shows the location of the Tocantins River Basin (TRB) with the thirty-two streamflow gauging stations, and the twelve hydropower plants.

Table 1. The characteristics of streamflow gauging stations in Tocantins River Basin.

\begin{tabular}{|c|c|c|c|c|c|}
\hline Station $\mathrm{n}^{\circ}$ & Station ID & $\mathrm{DA}\left(\mathrm{km}^{2}\right)$ & Affected by reservoir & $\begin{array}{l}\text { Most influential HPP } \\
\text { installation year }\end{array}$ & Record length \\
\hline S01 & 20050000 & 11008 & No & - & $1966-2012$ \\
\hline S02 & 20100000 & 1585.2 & No & - & $1965-2017$ \\
\hline S03 & 20200000 & 2772.3 & No & - & $1965-2017$ \\
\hline S04 & 20950000 & 884 & No & - & $1980-2006$ \\
\hline S05 & 21220000 & 7277 & No & - & $1976-2017$ \\
\hline S06 & 21300000 & 2260 & Yes & 2006 & $1975-2005$ \\
\hline S07 & 21500000 & 20212.7 & Yes & 2006 & $1971-2005$ \\
\hline S08 & 21510000 & 795 & No & - & $1975-2005$ \\
\hline S09 & 21560000 & 2733.5 & Yes & 1991 & $1977-1990$ \\
\hline S10 & 21580000 & 281.4 & No & - & $1975-2014$ \\
\hline S11 & 21750000 & 1224 & No & - & $1975-2014$ \\
\hline $\mathrm{S} 12$ & 22050001 & 122319.8 & Yes & 1998 & $1971-1997$ \\
\hline S13 & 22100000 & 8682.9 & No & - & $1975-2014$ \\
\hline S14 & 22150000 & 13582.9 & No & - & $1972-2005$ \\
\hline $\mathrm{S} 15$ & 22190000 & 1767 & Yes & 1994 & $1976-1993$ \\
\hline S16 & 22220000 & 10077.3 & Yes & 1994 & 1975 - 1993 \\
\hline S17 & 22250000 & 14424.7 & Yes & 1994 & 1970 - 1993 \\
\hline S18 & 22500000 & 178453.3 & Yes & 1998 & 1970 - 1997 \\
\hline S19 & 22680000 & 16862 & No & - & $1974-2017$ \\
\hline S20 & 22700000 & 17535.1 & No & - & $1972-2014$ \\
\hline $\mathrm{S} 21$ & 22850000 & 9396.6 & No & - & $1974-2009$ \\
\hline $\mathrm{S} 22$ & 22900000 & 43376.7 & No & - & 1970 - 2017 \\
\hline $\mathrm{S} 23$ & 23100000 & 235213.9 & Yes & 1998 & 1970 - 1997 \\
\hline $\mathrm{S} 24$ & 23150000 & 2854.8 & No & - & $1974-2017$ \\
\hline S25 & 23220000 & 2938.4 & No & - & $1985-2014$ \\
\hline $\mathrm{S} 26$ & 23230000 & 4031.1 & No & - & $1984-2014$ \\
\hline $\mathrm{S} 27$ & 23250000 & 9809.8 & No & - & $1972-2017$ \\
\hline S28 & 23300000 & 267392.3 & Yes & 1998 & $1962-1997$ \\
\hline $\mathrm{S} 29$ & 23600000 & 281136.9 & Yes & 1998 & $1955-1997$ \\
\hline $\mathrm{S} 30$ & 23650000 & 1566.9 & No & - & $2000-2014$ \\
\hline S31 & 23700000 & 287336.3 & Yes & 1998 & $1974-1997$ \\
\hline S32 & 23710000 & 287405.5 & Yes & 1998 & $1970-1997$ \\
\hline
\end{tabular}




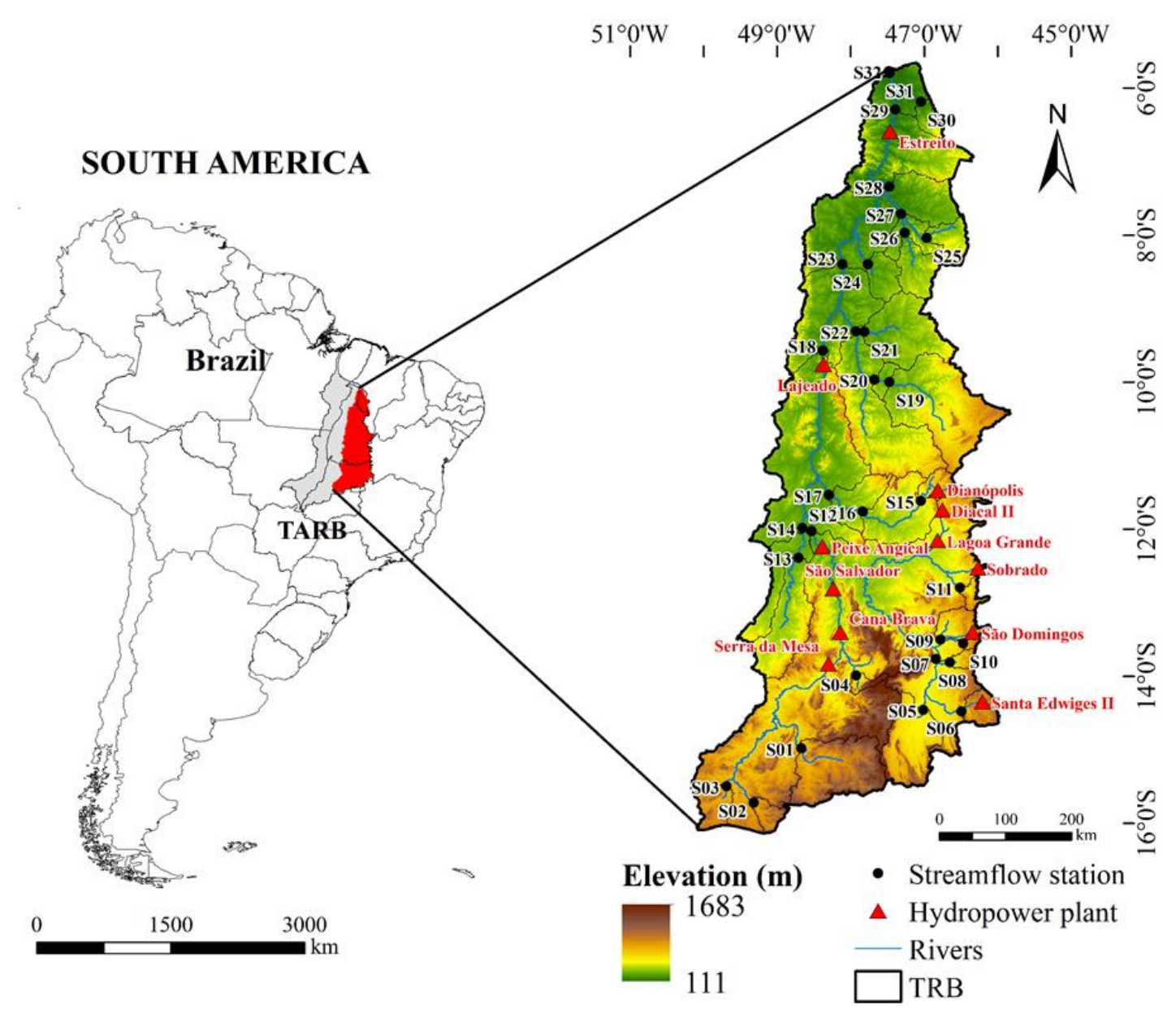

Figure 1. Geographical location of the Tocantins River Basin (TRB) with the thirty-two streamflow stations and the twelve hydropower plants.

Based on the daily streamflow historical series of the 32 streamflow gauging stations, three new series were generated for each station, referring to: the maximum annual streamflow $\left(\mathrm{Q}_{\max }\right)$, mean annual streamflow $\left(\mathrm{Q}_{\text {mean }}\right)$ and mean minimum streamflow over seven consecutive days $\left(\mathrm{Q}_{7}\right)$.

The first analysis in this study was to determine which series were stationary and therefore could be used as a basis for regionalization. To determine whether a given historical series is stationary, it is necessary to apply a trend test (Naghettini and Pinto, 2007). The Mann-Kendall (MK) test (Mann, 1945; Kendall, 1975) is the most recommended to evaluate trends in hydrological time series (Hamed, 2008; Zhang et al., 2015; Wang et al., 2015). Thus, this test was applied to the 32 historical series of $\mathrm{Q}_{\max }, \mathrm{Q}_{\text {mean }}$ and $\mathrm{Q}_{7}$ to select those data to be used in the streamflow regionalization. This is one of the most important steps in the flow regionalization process, as it prevents the spread of local trends to the rest of the basin, which justified the exclusion of periods subsequent to the installation of the reservoirs. This test was performed using the Kendall package from RStudio.

Daily series from stations whose $\mathrm{Q}_{\text {mean }}$ series are stationary were used to obtain $\mathrm{Q}_{90 \%}$, Q95\% and $\mathrm{Q}_{\mathrm{ltm}}$ (Beskow et al., 2016). For the stations whose $\mathrm{Q}_{7}$ series are stationary, PDFs (probability distribution functions) were fitted to obtain the quantile associated with the return period (RP) of 10 years $\left(\mathrm{Q}_{7,10}\right)$. For the stations with $\mathrm{Q}_{\max }$ stationary series, PDFs were fitted to regionalize the maximum annual streamflows as a function of RP.

\subsection{Probability distribution functions (PDF)}

To regionalize streamflows associated with RPs, it is necessary to model the frequency of 
occurrence by a PDF. $\mathrm{Q}_{\max }$ and $\mathrm{Q}_{7}$ were modeled by different PDFs, selecting the most adequate for each situation.

The following PDFs were fitted to the maximum annual streamflow series: two-parameter log-normal (LN2); Gumbel (or Extreme Values - EV1); Generalized Pareto (GPA); Gamma (GAM); three-parameter log-normal (LN3); Generalized extreme values (GEV); Pearson type III (PE3); Generalized logistic (GLO); Kappa (KAP); and Wakeby (WAK). These distributions were also fitted by Cassalho et al. $(2018 ; 2019)$ to historical streamflow series from watersheds in Rio Grande do Sul. The same distributions were fitted to $\mathrm{Q}_{7}$ series, except GPA distribution, however, Weibull distribution was also fitted to these series. Detailed descriptions of these PDFs are further presented in Naghettini and Pinto (2007) and Cassalho et al. (2018).

The L-moments method was used to estimate the parameters of the PDFs (Hosking and Wallis, 1997; Cassalho et al., 2017). The best PDF for each $\mathrm{Q}_{7}$ historical series was selected based on the Anderson-Darling (AD) goodness of fit test (Anderson and Darling, 1954), with a significance level of 5\%, being the one with the lowest Anderson-Darling value among the PDFs. The adequate PDF to regionalize $\mathrm{Q}_{\max }$ streamflow was also selected based on the Anderson-Darling goodness of fit test, with a significance level of 5\%. However, it was the one that fitted all $Q_{\max }$ series and presented lower $A D$ value among the PDFs that fitted all $Q_{\max }$ series. The Anderson-Darling test places more weight on observations in the tails of the PDFs, which is a desirable feature when modeling extreme events (Naghettini and Pinto, 2007).

\subsection{Streamflow regionalization}

Streamflow regionalization allows transferring information from a basin where data are available to another where little or no data are available through a mathematical model that is valid for a hydrologically homogeneous region (Naghettini and Pinto, 2007). Thus, to evaluate the homogeneity of the TRB, the non-parametric index-flood method was applied to the $\mathrm{Q}_{\max }$, $\mathrm{Q}_{\text {mean }}$ and $\mathrm{Q}_{7}$ historical series that showed stationarity. This method was originally introduced by Dalrymple (1960) and exhibits good results.

Typically, index-flood method is based on the analyses of a graphically frequency distribution of the dimensionless streamflows from each station. This analysis is the preliminary step of the dimensionless curve regionalization method (Euclydes et al., 2001). To apply this method, the streamflows were initially dimensionless as follows (Equation 1):

$$
Q_{i d}=\frac{Q_{i}}{Q_{\text {mean }}}
$$

Where $\mathrm{Q}_{\mathrm{id}}$ is the dimensionless streamflow, $\mathrm{Q}_{\mathrm{i}}$ is the observed streamflow in ascending order at position $\mathrm{i}$, and $\mathrm{Q}_{\text {mean }}$ is the average observed streamflows of the series.

The frequency of occurrence of the events was calculated by applying the Weibull procedure (Equation 2):

$P\left(Q_{i d}\right)=\frac{i}{N+1}$

Where $\mathrm{P}\left(\mathrm{Q}_{\mathrm{id}}\right)$ is the non-exceedance frequency of the streamflow of order $\mathrm{i}$ and $\mathrm{N}$ is the number of events.

After obtaining the dimensionless streamflows and their respective frequencies of occurrence, these data were plotted. To evaluate the homogeneity of the $\mathrm{Q}_{\max }, \mathrm{Q}_{\text {mean }}$ and Q7 series, three graphics were plotted (one for each set). This method considers that the dimensionless streamflow versus frequency of occurrence curves for stations within the same hydrologically homogeneous region are similar, thus configuring the criterion for the identification of homogeneous regions. 
The homogeneous regions identified by the index-flood method for $\mathrm{Q}_{\max }$ were used in the regionalization of the maximum annual streamflows as function of RP. The regions identified for $\mathrm{Q}_{\text {mean }}$ were used in the regionalization of $\mathrm{Q}_{1 \mathrm{tm}}, \mathrm{Q}_{90 \%}$ and $\mathrm{Q}_{95 \%}$, and those identified for $\mathrm{Q}_{7}$ were used in the regionalization of $\mathrm{Q}_{7,10}$.

To develop the regionalization models, it is essential to know the independent variables that better explain streamflow behaviors. The independent variables to describe this relationship could be the drainage area, drainage density, length and steepness of the main river, average annual rainfall, land cover, among others (de Souza et al., 2021). Cassalho et al. $(2017 ; 2019)$ highlight that to reduce uncertainties related to the regionalization process, the parsimony principle should be considered, which means that a phenomenon should be explained with the lowest number of explanatory variables. In this way, this study used the drainage area as an explanatory variable. Drainage area is the variable most used in different regionalization studies (Naghettini and Pinto, 2007; Beskow et al., 2016; Melati and Marcuzzo, 2016; Bazzo et al., 2017), mainly because it is easily obtained, enabling the use of the generated models in ungauged basins. Thus, the drainage area of each sub-basin was obtained using the ASTER (Advanced Spaceborne Thermal Emission and Reflection Radiometer) digital elevation model (DEM) combined with calculations made using the Raster Calculator Tool in ArcGIS 10.1 (ESRI, 2013).

According to Naghettini and Pinto (2007), the main methods applied to streamflow regionalization in a hydrologically homogeneous region are (i) the method that regionalizes the quantiles associated with a previously specified risk and (ii) the method that regionalizes a dimensionless probability curve, which is called the index-flood method. Method (i) was applied to regionalize $\mathrm{Q}_{1 \mathrm{tm}}, \mathrm{Q}_{90 \%}, \mathrm{Q}_{95 \%}$ and $\mathrm{Q}_{7,10}$. Method (ii) was used to regionalize the maximum annual streamflows as a function of RP (PDF regionalization). These regionalizations allow the estimation of varied quantiles to the most diverse demands in the homogeneous region, thus, are tools of extreme importance for water resources management.

The streamflows associated with specific risks were regionalized by fitting a regression model, which considers streamflow to be regionalized as the dependent variable and, in the case of this study, the drainage area as the independent variable.

The regionalization of the maximum annual streamflows as a function of $R P\left(Q_{\max }(R P)\right)$ using the index-flood method was performed based on the following Equation 3:

$$
Q \max (R P)=X^{R P} \cdot Q \operatorname{mean} \_\max
$$

Where $Q_{\max }(R P)$ is the estimated maximum annual streamflow for a given return period and $\mathrm{X}^{\mathrm{RP}}$ is the dimensionless regional quantile function obtained parametrically by fitting a PDF to the dimensionless regional data. This PDF must fit all $\mathrm{Q}_{\max }$ series within the homogeneous region. Qmean_max is the scaling factor known as "index flood," which consists of the regional function of the mean maximum annual streamflow (mean of the $Q_{\max }$ series) as a function of the drainage area, which is obtained using method (i).

Regionalization models were fitted according to the power mathematical model, as suggested by Lisboa et al. (2008), Beskow et al. (2016) and Cassalho et al. (2017). To evaluate the capability of the regional models, the cross-validation method was applied using the root mean square error (RMSE) and the coefficient of determination $\left(\mathrm{R}^{2}\right)$ as objective functions (Vezza et al., 2010). In addition, to quantify the performance of the regional models and compare the observed quantiles to the estimated ones, the confidence index (c) proposed by Camargo and Sentelhas (1997) was used according to the following classification: c> 0.85 (excellent), $0.76 \leq \mathrm{c} \leq 0.85$ (very good), $0.66 \leq \mathrm{c} \leq 0.75$ (good), $0.61 \leq \mathrm{c} \leq 0.65$ (moderate), $0.51 \leq \mathrm{c} \leq 0.60$ (fair), $0.41 \leq \mathrm{c} \leq 0.50$ (poor), and $\mathrm{c} \leq 0.40$ (very poor). 


\section{RESULTS AND DISCUSSION}

\subsection{Preliminary analysis and delimitation of the homogeneous regions}

Based on the Mann-Kendall test, out of 32 streamflow-gauging stations with at least 10 years of data, 23 stations for the $\mathrm{Q}_{\max }$ series, 18 for the $\mathrm{Q}_{\text {mean, }}$ and 14 stations for $\mathrm{Q}_{7}$ series could be considered stationary and adequate for regionalization.

Figures 2a, 2b and 2e depict the empirical dimensionless streamflow versus frequency curves for the $\mathrm{Q}_{\text {mean }}, \mathrm{Q}_{\max }$ and $\mathrm{Q}_{7}$ series, respectively. Figure 2a shows that the 18 streamflow gauging stations had similar behavior, thus forming a single homogeneous region regarding $\mathrm{Q}_{\text {mean. }}$. However, Figure $2 \mathrm{~b}$ shows that the $23 \mathrm{Q}_{\max }$ series did not have the same behavior and therefore should not comprise a single homogeneous region. Therefore, for $\mathrm{Q}_{\max }$, the existence of two homogeneous regions was observed, namely, one region consisting of 7 streamflow stations, Region 1 (Figure 2c), and the other region consisting of 16 streamflow stations, Region 2 (Figure 2d). Figure 2e shows that the 14 historical $\mathrm{Q}_{7}$ series did not indicate homogeneous behavior. Graphical analysis indicates that a homogeneous region with 10 streamflow stations can be defined (Figure 2f). However, the other series did not conform to each other, and to define a second homogeneous region for this variable was not possible. A similar process was applied by Noto and La Loggia (2009), who removed approximately $8 \%$ of the data because they did not show behavior consistent with the defined hydrological region. Table 2 presents the systematization of the homogeneous regions for the $\mathrm{Q}_{\max }, \mathrm{Q}_{\mathrm{mean}}$, and $\mathrm{Q}_{7}$ series. In addition, it can be seen in Table 2 that the stations did not present common periods, since according to Hosking and Wallis (1997) the series can be considered homogenous and representative of the variable under analysis, so that the use of the same period is unnecessary.

Table 2. Homogeneous regions for the $\mathrm{Q}_{\max }, \mathrm{Q}_{7}$ and $\mathrm{Q}_{\text {mean }}$ series.

\begin{tabular}{cccccccccc}
\hline Station & Years & $\mathrm{Q}_{\max }$ & $\mathrm{Q}_{7}$ & $\mathrm{Q}_{\text {mean }}$ & Station & Years & $\mathrm{Q}_{\max }$ & $\mathrm{Q}_{7}$ & $\mathrm{Q}_{\text {mean }}$ \\
\hline 20050000 & 45 & ET & ET & ET & 22250000 & 24 & 2 & 1 & 1 \\
20100000 & 52 & 1 & ER & 1 & 22500000 & 28 & 2 & 1 & 1 \\
20200000 & 53 & 1 & ET & 1 & 22680000 & 44 & ET & ET & ET \\
20950000 & 27 & ET & ET & ET & 22700000 & 43 & ET & ET & ET \\
21220000 & 41 & ET & ET & ET & 22850000 & 34 & 1 & ET & ET \\
21300000 & 31 & 1 & ER & 1 & 22900000 & 48 & 2 & ET & ET \\
21500000 & 35 & 1 & 1 & 1 & 23100000 & 28 & 2 & 1 & 1 \\
21510000 & 29 & 2 & ET & 1 & 23150000 & 44 & 2 & ET & ET \\
21560000 & 13 & ET & ER & 1 & 23220000 & 30 & 1 & 1 & 1 \\
21580000 & 35 & ET & ET & ET & 23230000 & 31 & ET & ET & 1 \\
21750000 & 40 & ET & ET & ET & 23250000 & 46 & 2 & ET & ET \\
22050001 & 27 & 2 & 1 & 1 & 23300000 & 36 & 2 & ET & 1 \\
22100000 & 37 & 1 & ET & ET & 23600000 & 43 & 2 & 1 & 1 \\
22150000 & 34 & 2 & ET & ET & 23650000 & 14 & 2 & 1 & 1 \\
22190000 & 18 & 2 & ER & 1 & 23700000 & 24 & 2 & ET & ET \\
22220000 & 19 & 2 & 1 & 1 & 23710000 & 28 & 2 & 1 & 1 \\
\hline
\end{tabular}

Note: ET - Excluded from the Mann-Kendall test. ER - Excluded from the delineation of homogeneous regions. Regions 1 and 2 are homogeneous. 


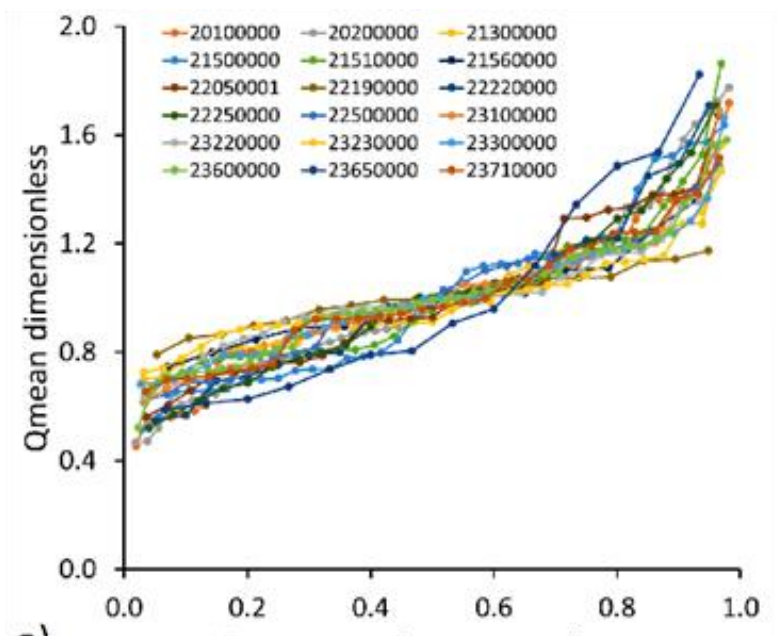

a)
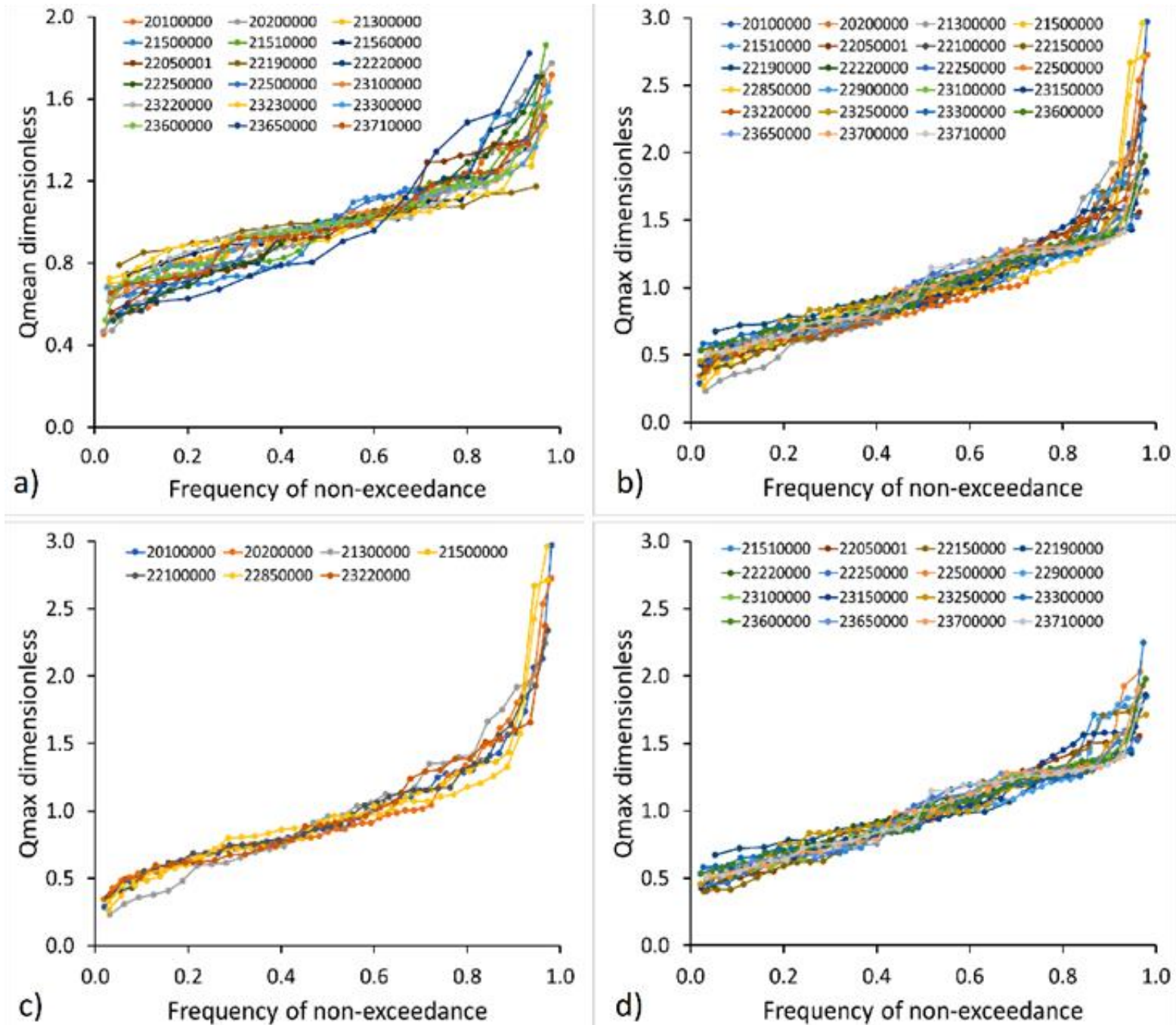

b) Frequency of non-exceedance

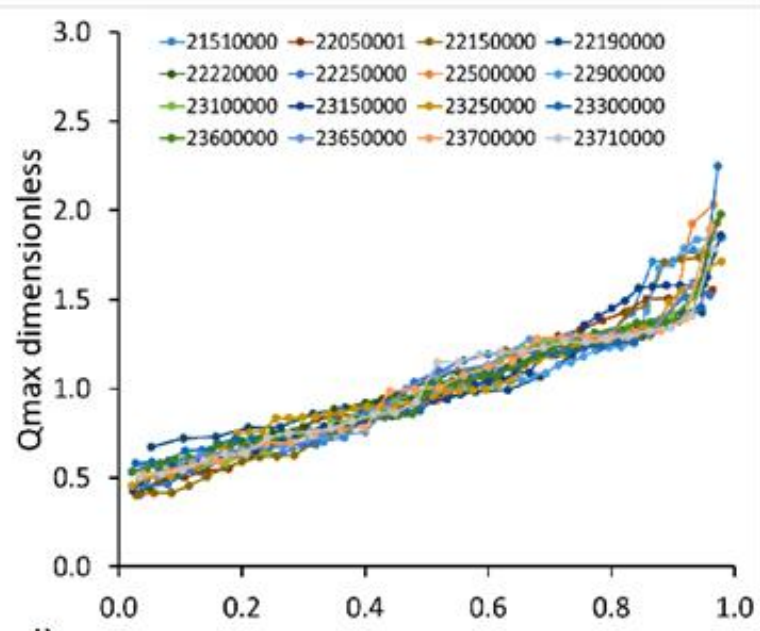

d) Frequency of non-exceedance

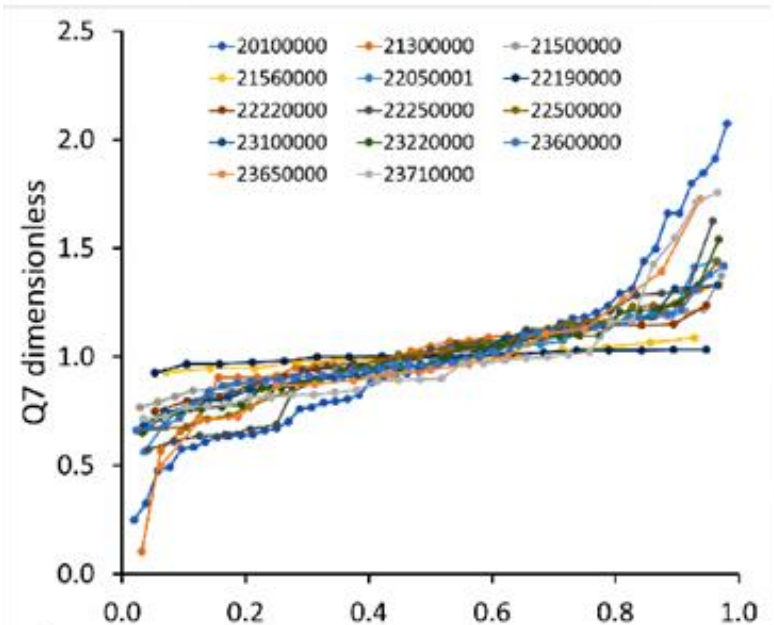

e)

Frequency of non-exceedance

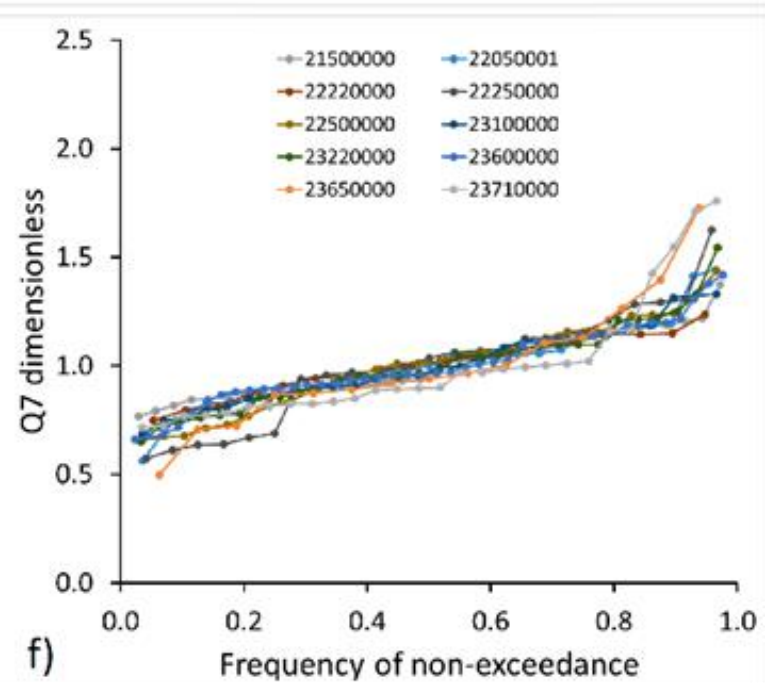

Figure 2. Index-flood method applied to the mean annual streamflow (a) and maximum annual streamflow (b) series; subdivision of the maximum annual streamflows into two homogeneous regions, Region 1 (c) and Region 2 (d); minimum streamflow over seven consecutive days (e); and definition of a homogeneous region for $\mathrm{Q}_{7}(\mathrm{f})$.

The geographic location of the homogeneous regions determined for the $\mathrm{Q}_{\text {mean }}, \mathrm{Q}_{\max }$ and $\mathrm{Q}_{7}$ is shown in Figures $3 \mathrm{a}, \mathrm{b}$ and c. Possible characteristics that led to the differentiation between homogeneous regions and the removal of some series were identified based on the 
evaluation of the physiographic characteristics of the TRB. Such characteristics were obtained from land use (IBGE, 2000), soils (EMBRAPA, 2011), hydrogeological (Diniz et al., 2014) and slope (ASTER DEM) maps. For the $\mathrm{Q}_{\max }$ homogeneous regions, Figures $2 \mathrm{c}$ and $2 \mathrm{~d}$ show that Region 1 has a wider range of variation than Region 2. Thus, Region 1 was found to have characteristics that favor surface runoff, such as a high percentage of anthropogenic land cover and Petric Plinthosol, which has a low infiltrability. Regarding the removal of some $\mathrm{Q}_{7}$ series, Figures $2 \mathrm{e}$ and $2 \mathrm{f}$ show that the excluded series have more complex characteristics than the rest of the basin, such as amplitude of variation. Thus, based on the physiographic evaluation of these areas, it was observed that the basins having the smallest amplitude of variation in $\mathrm{Q}_{7}$ are small drainage areas with a low slope and high hydrogeological favorability, as demonstrated by the Urucuia aquifer.

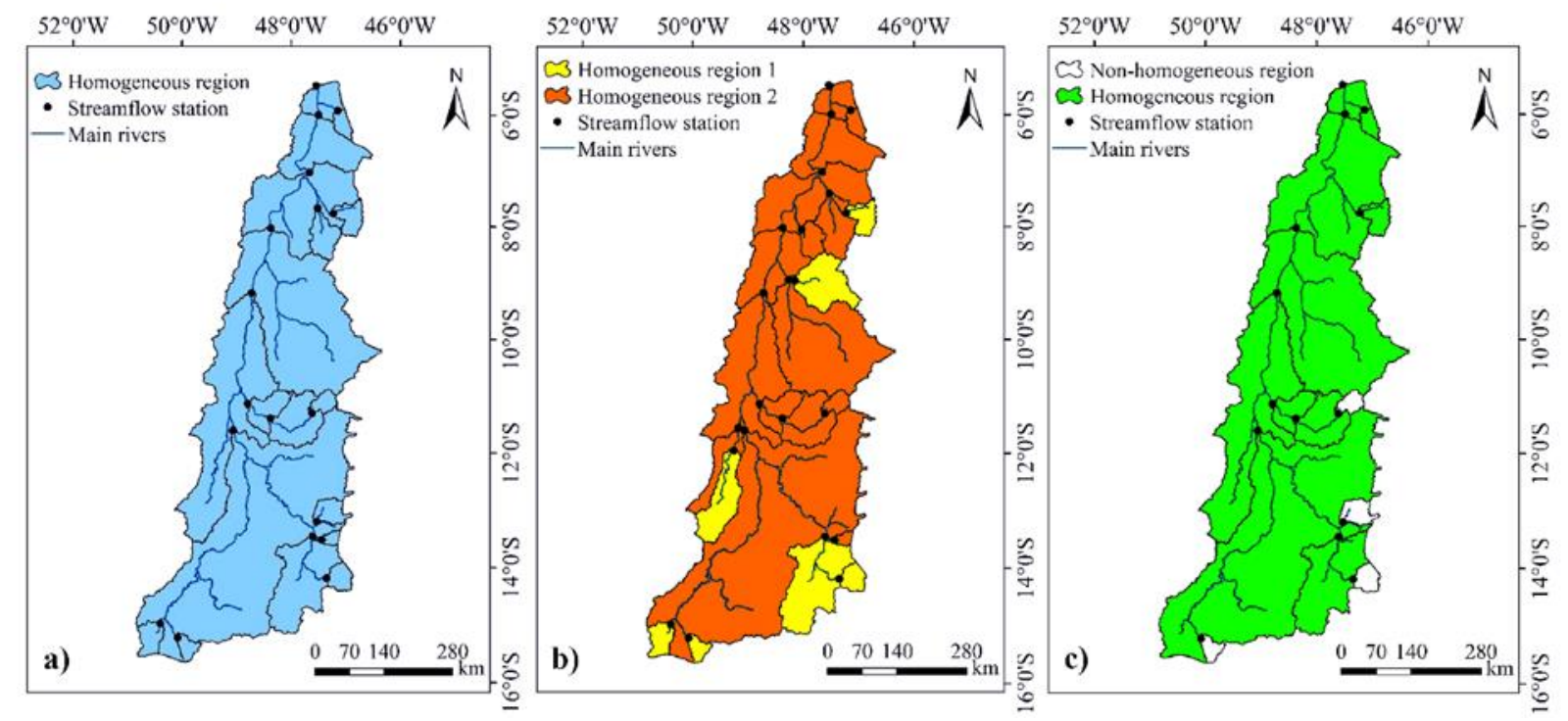

Figure 3. Geographic location of the homogeneous regions of the TRB determined by the index-flood method for $\mathrm{Q}_{\text {mean }}(\mathrm{a}), \mathrm{Q}_{\max }(\mathrm{b})$ and $\mathrm{Q}_{7}(\mathrm{c})$.

\subsection{Regionalization of $\mathbf{Q}_{90 \%}, \mathbf{Q}_{95 \%}$ and $\mathbf{Q}_{\mathrm{Itm}}$}

Table 3 shows the minimum with $90 \%$ and $95 \%$ permanence $\left(\mathrm{Q}_{90 \%}\right.$ and $\left.\mathrm{Q}_{95 \%}\right)$ and longterm mean $\left(\mathrm{Q}_{\mathrm{ltm}}\right)$ streamflows obtained by means of the permanence curves of the observed data at each of the 18 streamflow-gauging stations. Table 4 shows the regionalization models of $\mathrm{Q}_{90 \%}, \mathrm{Q}_{95 \%}$ and $\mathrm{Q}_{1 \mathrm{tm}}$ streamflows fitted for the Tocantins River Basin. It can be seen in Table 4 that the three models fitted are classified as "excellent" based on a confidence index value (c) $>0.85$ (Camargo and Sentelhas, 1997). Besides that, the $\mathrm{R}^{2}$ values showed that the models explain at least $98 \%$ of the variation in $\mathrm{Q}_{90 \%}, \mathrm{Q}_{95 \%}$ and $\mathrm{Q}_{\mathrm{ltm}}$. When regionalizing $\mathrm{Q}_{90 \%}$ for river basins fully inserted in the state of Rio Grande do Sul, Brazil, Beskow et al. (2016) obtained models with confidence indices (c) ranging from 0.71 to 0.99 , considering the drainage area as the only explanatory variable. When regionalizing Q $_{95 \%}$ for the Taquari-Antas River Basin, located in the state of Rio Grande do Sul, Brazil, Bazzo et al. (2017) obtained models with $\mathrm{R}^{2}$ coefficients ranging from 0.77 to 0.99 , also considering the drainage area as the only explanatory variable. Thus, the models provided in this study can be used for the estimation of $\mathrm{Q}_{90 \%}, \mathrm{Q}_{95 \%}$ and $\mathrm{Q}_{\mathrm{ltm}}$ in ungauged basins in the Tocantins River Basin, within the homogeneous region for mean annual streamflow and within the drainage area boundary from 795 to $287,405.5 \mathrm{~km}^{2}$. Therefore, they are important tools in the context of the quantitative management of water resources and for Cerrado biome conservation, since the $\mathrm{Q}_{90 \%}$ and $\mathrm{Q}_{95 \%}$ are the reference streamflows for granting water use rights in the states of Goiás, Tocantins and Maranhão, located in the studied basin. 
Table 3. Data of streamflow-gauging stations used to regionalize $\mathrm{Q}_{90 \%}, \mathrm{Q}_{95 \%}$ and $\mathrm{Q}_{\mathrm{ltm}}$ and their respective values estimated by historical series.

\begin{tabular}{ccccc}
\hline Station & Drainage Area $\left(\mathrm{km}^{2}\right)$ & $\mathrm{Q}_{\mathrm{Itm}}\left(\mathrm{m}^{3} \mathrm{~s}^{-1}\right)$ & $\mathrm{Q}_{90 \%}\left(\mathrm{~m}^{3} \mathrm{~s}^{-1}\right)$ & $\mathrm{Q}_{95 \%}\left(\mathrm{~m}^{3} \mathrm{~s}^{-1}\right)$ \\
\hline 20100000 & 1585.2 & 33.22 & 8.53 & 6.91 \\
20200000 & 2772.3 & 60.24 & 13.39 & 10.10 \\
21300000 & 2260.0 & 54.87 & 30.65 & 28.23 \\
21500000 & 20212.7 & 208.46 & 61.65 & 56.39 \\
21510000 & 795.0 & 14.70 & 7.01 & 6.66 \\
21560000 & 2733.5 & 48.95 & 23.85 & 22.90 \\
22050001 & 122319.8 & 1848.67 & 612.30 & 552.93 \\
22190000 & 1767.0 & 45.54 & 27.20 & 26.84 \\
22220000 & 10077.3 & 151.50 & 30.19 & 27.90 \\
22250000 & 14424.7 & 211.93 & 37.11 & 31.49 \\
22500000 & 178453.3 & 2539.28 & 641.81 & 548.30 \\
23100000 & 235213.9 & 3584.10 & 1014.64 & 906.73 \\
23220000 & 2938.4 & 32.58 & 12.74 & 11.35 \\
23230000 & 4031.1 & 77.73 & 33.85 & 31.89 \\
23300000 & 267392.3 & 4033.50 & 1188.63 & 1059.14 \\
23600000 & 281136.9 & 4509.36 & 1321.20 & 1185.28 \\
23650000 & 1566.9 & 26.37 & 3.35 & 2.92 \\
23710000 & 287405.5 & 4810.91 & 1428.29 & 1286.68 \\
\hline
\end{tabular}

Table 4. Regionalization models for $\mathrm{Q}_{90 \%}, \mathrm{Q}_{95 \%}$ and $\mathrm{Q}_{\mathrm{ltm}}\left(\mathrm{m}^{3} \mathrm{~s}^{-1}\right)$ as a function of the drainage area (DA) $\left(\mathrm{km}^{2}\right)$ for the $\mathrm{Q}_{\text {mean }}$ streamflow hydrologically homogeneous region of the Tocantins River Basin, and their results of the performance evaluation indexes.

\begin{tabular}{ccccccc}
\hline \multirow{2}{*}{ Regionalization model } & \multicolumn{3}{c}{ Fitting } & \multicolumn{3}{c}{ Cross-validation } \\
\cline { 2 - 7 } & $\mathrm{R}^{2}$ & RMSE & $\mathrm{c}$ & $\mathrm{R}^{2}$ & RMSE & $\mathrm{c}$ \\
\hline $\mathrm{Q}_{90 \%}=4.2306 \times 10^{-4} \mathbf{D A}^{1.1912}$ & 0.991 & 52.49 & 0.993 & 0.975 & 86.15 & 0.981 \\
$\mathrm{Q}_{95 \%}=2.6040 \times 10^{-4} \mathbf{D A}^{1.2211}$ & 0.988 & 52.88 & 0.991 & 0.968 & 86.94 & 0.975 \\
$\mathrm{Q}_{\mathrm{ltm}}=2.4323 \times 10^{-3} \mathbf{D A}^{1.1498}$ & 0.998 & 91.74 & 0.998 & 0.995 & 132.24 & 0.996 \\
\hline
\end{tabular}

\subsection{Regionalization of $\mathbf{Q}_{7,10}$}

Table 5 shows the best PDF used to adjust the $\mathrm{Q}_{7}$ series at each of the 10 streamflowgauging stations and their respective estimated values of $\mathrm{Q}_{7}$ streamflow for a return period of 10 years $\left(\mathrm{Q}_{7,10}\right)$. The best PDF was the one with the lowest Anderson-Darling (AD) test value among the adequate PDFs, considering a significance level of 5\%. The Wakeby PDF showed the best performance among the PDFs for 5 historical series, the Weibull PDF showed the best performance for 2 series, and the Pearson, GLO and GEV PDFs showed the best performance for 1 historical series each. Leme and Chaudhry (2005), comparing the Weibull and Gumbel PDFs in the determination of $\mathrm{Q}_{7,10}$ streamflow in the Jaguari Mirim River Basin, Brazil, pointed to the Weibull distribution as the one that provides the best fit. Chen et al. (2006), comparing five PDFs in the determination of $\mathrm{Q}_{7,10}$ streamflow in the Dongjiang basin, South China, pointed to the three-parameter lognormal (LN3) distribution as the one that provides the best fit, outperforming generalized logistic (GLO), generalized extreme value (GEV), Pearson type III 
(PIII) and generalized Pareto (GPD) distributions. Amorim et al. (2020), characterizing the $\mathrm{Q}_{7,10}$ streamflow in the Mortes River Basin, southeastern Brazil, tested ten PDFs, the same ones studied in this work. The distributions that stood out most were those of Wakeby, Kappa, GEV, GLO, GPA, Weibull and PE3, which showed the best performance for 8, 3, 2, 1, 1, 1 and 1 series, respectively. Thus, it can be seen that there is not a better PDF for all regions, thereby, to reduce errors in the $\mathrm{Q}_{7,10}$ estimate, one can highlight the importance of this PDFs analysis.

Table 5. The best PDF used to adjust the $\mathrm{Q}_{7}$ series at each of the 10 streamflow gauging stations, along with its Anderson-Darling (AD) test value and estimated value of $\mathrm{Q}_{7,10}$.

\begin{tabular}{ccccc}
\hline Station & Drainage Area $\left(\mathrm{km}^{2}\right)$ & Best PDF & AD of the Best PDF & $\mathrm{Q}_{7,10}\left(\mathrm{~m}^{3} \mathrm{~s}^{-1}\right)$ \\
\hline 21500000 & 20212.7 & Pearson & 0.499 & 48.33 \\
22050001 & 122319.8 & GLO & 0.171 & 453.99 \\
22220000 & 10077.3 & Wakeby & 0.141 & 21.51 \\
22250000 & 14424.7 & Weibull & 0.513 & 20.92 \\
22500000 & 178453.3 & Weibull & 0.229 & 404.55 \\
23100000 & 235213.9 & Wakeby & 0.175 & 720.99 \\
23220000 & 2938.4 & Wakeby & 0.191 & 8.99 \\
23600000 & 281136.9 & Wakeby & 0.307 & 985.46 \\
23650000 & 1566.9 & Wakeby & 0.206 & 2.49 \\
23710000 & 287405.5 & GEV & 0.262 & 1066.01 \\
\hline
\end{tabular}

Table 6 shows the regionalization model of $\mathrm{Q}_{7,10}$ streamflow fitted for the $\mathrm{Q}_{7}$ streamflow hydrologically homogeneous region of the Tocantins River Basin, along with the accuracy statistics associated with fitting and cross-validation. It can be seen in Table 6 that the fitted model can explain $97.5 \%$ of the variation in $\mathrm{Q}_{7,10}$ based on only the drainage area. Furthermore, the confidence index value (c) $>0.85$ showed that the model is classified as "excellent" (Camargo and Sentelhas, 1997), which demonstrates the quality of the regionalization model. When regionalizing $\mathrm{Q}_{7,10}$ for the São Paulo State, Brazil, Wolff et al. (2014) obtained a model with confidence index (c) of 0.94 and $\mathrm{R}^{2}$ coefficient of 0.92 , considering the drainage area as the only explanatory variable. When regionalizing $\mathrm{Q}_{7,10}$ for the Mortes River Basin, southeastern Brazil, Amorim et al. (2020) obtained model with $\mathrm{R}^{2}$ coefficient of 0.99 , also considering the drainage area as the only explanatory variable. Thus, the $\mathrm{Q}_{7,10}$ model provided in this study can be used in ungauged basins in the Tocantins River Basin, within the $\mathrm{Q}_{7}$ streamflow hydrologically homogeneous region and within the drainage area boundary from 1566.9 to $287,405.5 \mathrm{~km}^{2}$. The previous finding is important, since $\mathrm{Q}_{7,10}$ is used as reference streamflow for the water use right concession in Minas Gerais, São Paulo and Espírito Santo states (ANA, 2007), close to the studied basin, thus, the $\mathrm{Q}_{7,10}$ model developed in the present study is an alternative for the management of water resources.

Table 6. Regionalization model for $\mathrm{Q}_{7,10}\left(\mathrm{~m}^{3} \mathrm{~s}^{-1}\right)$ as a function of the drainage area (DA) $\left(\mathrm{km}^{2}\right)$ for the $\mathrm{Q}_{7}$ streamflow hydrologically homogeneous region of the Tocantins River Basin, and its result of the performance evaluation indexes.

\begin{tabular}{ccccccc}
\hline \multirow{2}{*}{ Regionalization model } & \multicolumn{3}{c}{ Fitting } & \multicolumn{4}{c}{ Cross-validation } \\
\cline { 2 - 7 } & $\mathrm{R}^{2}$ & RMSE & $\mathrm{c}$ & $\mathrm{R}^{2}$ & RMSE & $\mathrm{c}$ \\
\hline $\mathrm{Q}_{7,10}=4.0506 \times 10^{-5} \mathbf{D A}^{1.3552}$ & 0.975 & 71.08 & 0.981 & 0.928 & 120.26 & 0.945 \\
\hline
\end{tabular}




\subsection{Regionalization of $Q_{\max }$}

Table 7 shows the results of the Anderson-Darling (AD) test for the best PDF, the one with the lowest AD value, and for GEV PDF, which was the only one accepted for all $\mathrm{Q}_{\max }$ series, considering a significance level of 5\%. The Wakeby PDF showed the best performance among the PDFs for 10 historical series of $Q_{\max }$, the Kappa and GEV PDFs showed the best performance for 4 historical series each, the Pearson PDF was the best for 3 series, and the LN2 and GLO PDFs showed the best performance for 1 historical series each. However, considering that the goal is to define a regional function that is capable of estimating the $Q_{\max }$ streamflow for different RPs, and that the GEV PDF was the only one that had a good fit for all $\mathrm{Q}_{\max }$ series within the homogeneous regions 1 and 2, the GEV PDF was adopted here. Morais et al. (2020), in a regionalization study for the Araguaia River Basin, Brazil, also identified the GEV PDF as the only one that had a good fit for all $Q_{\max }$ series. Kumar et al. (2003), when evaluating 12 PDFs in a regionalization study of $Q_{\max }$ for Middle Ganga Plains Subzone 1 (f) of India, identified the GEV PDF as the most robust. Noto and La Loggia (2009), comparing 4 PDFs in the determination of $\mathrm{Q}_{\max }$ streamflow in a case study on the island of Sicily, Italy, pointed to the GEV PDF as the one that provides the best fit. The robustness of the GEV for modeling $\mathrm{Q}_{\max }$ was also identified by Seckin et al. (2011), when evaluating 6 PDFs in Turkey; by Cassalho et al. (2017), when evaluating 6 PDFs in the Mirim-São Gonçalo Basin, Brazil; and by Cassalho et al. (2018), when evaluating 4 PDFs in Rio Grande do Sul state, Brazil. Therefore, the results of these studies corroborate the findings of the present study.

Table 7 also shows the fitted parameters of the GEV distribution and the length of each series. From these data, it was possible to estimate the regional parameters of the GEV distribution by means of the mean weighted by the length of the series, as recommended by Naghettini and Pinto (2007). The regional parameters of the GEV PDF obtained for Region 1 were $\xi=0.766, \alpha=0.328$ and $\kappa=-0.125$, and for Region 2 were $\xi=0.849, \alpha=0.315$ and $\kappa=$ 0.112. Therefore, the term $\mathrm{X}^{\mathrm{RP}}$ of Equation 3 was defined for both regions.

Table 7 also shows the mean maximum annual streamflow ( $\left.Q_{\text {mean_max }}\right)$ observed at each of the 23 streamflow-gauging stations. Table 8 shows the regionalization models of $\mathrm{Q}_{\text {mean_max }}$ streamflow fitted as a function of the drainage area for the homogeneous regions 1 and 2 of the TRB. It can be seen in Table 8 that the fitted models are classified as "excellent" based on the confidence index value (c) $>0.85$ (Camargo and Sentelhas, 1997). In addition, the $\mathrm{R}^{2}$ values showed that the models explain at least $86 \%$ of the variation in $Q_{\text {mean_max }}$ streamflow, and the cross-validation results demonstrated the predictive ability of the models. When regionalizing Qmean_max in a case study on the island of Sicily, Italy, Noto and La Loggia (2009) obtained a model with $\mathrm{R}^{2}$ coefficient of 0.77 , considering the drainage area as the only explanatory variable. When regionalizing $\mathrm{Q}_{\text {mean_max }}$ for the Araguaia River Basin, Brazil, Morais et al. (2020) obtained power mathematical models with $\mathrm{R}^{2}$ coefficients ranging from 0.87 to 0.9 and confidence index values (c) $>0.85$, considering the drainage area as the only explanatory variable. When regionalizing $Q_{\text {mean_max }}$ for the state of Rio Grande do Sul, Brazil, Cassalho et al. (2018) obtained models with $\mathrm{R}^{2}$ coefficients ranging from 0.57 to 0.96 , also considering the drainage area as the only explanatory variable. Thus, the $\mathbf{Q}_{\text {mean_max }}$ models provided in this study can be used in ungauged basins in the Tocantins River Basin, within their respective $\mathrm{Q}_{\max }$ streamflow homogeneous regions, and within the drainage area boundary from 795 to $287,405.5 \mathrm{~km}^{2}$ (Region 1) and from 1585.2 to $20,212.7 \mathrm{~km}^{2}$ (Region 2). Therefore, the term "index flood" of Equation 3 was defined for both regions. 
Table 7. Results of the Anderson-Darling (AD) goodness of fit test and the parameters of position $(\xi)$, scale ( $\alpha$ ) and shape ( $\kappa)$ fitted for the GEV PDF, along with the observed $\mathrm{Q}_{\text {mean_max }}$ streamflow and the length of the data series in years $(\mathrm{N})$ at each of the 23 streamflow-gauging stations.

\begin{tabular}{|c|c|c|c|c|c|c|c|c|c|}
\hline Station & Drainage Area $\left(\mathrm{km}^{2}\right)$ & $\mathrm{Q}_{\text {mean_max }}\left(\mathrm{m}^{3} \mathrm{~s}^{-1}\right)$ & Best PDF & $\mathrm{AD}$ of the Best PDF & $\mathrm{AD}$ of the GEV PDF & $\xi$ & $\alpha$ & $\kappa$ & $\mathrm{N}$ \\
\hline 20100000 & 1585.2 & 168.25 & Kappa & 0.115 & 0.119 & 0.769 & 0.318 & -0.132 & 52 \\
\hline 20200000 & 2772.3 & 368.14 & GEV & 0.25 & 0.25 & 0.752 & 0.285 & -0.231 & 53 \\
\hline 21300000 & 2260.0 & 401.78 & Kappa & 0.113 & 0.157 & 0.757 & 0.447 & 0.034 & 31 \\
\hline 21500000 & 20212.7 & 1271.00 & GLO & 0.165 & 0.224 & 0.746 & 0.328 & -0.169 & 35 \\
\hline 21510000 & 795.0 & 100.23 & Pearson & 0.296 & 0.319 & 0.812 & 0.352 & 0.046 & 29 \\
\hline 22050001 & 122319.8 & 9580.38 & Wakeby & 0.212 & 0.343 & 0.866 & 0.366 & 0.264 & 27 \\
\hline 22100000 & 8682.9 & 593.14 & Wakeby & 0.142 & 0.162 & 0.788 & 0.324 & -0.072 & 37 \\
\hline 22150000 & 13582.9 & 793.96 & Wakeby & 0.193 & 0.326 & 0.815 & 0.391 & 0.117 & 34 \\
\hline 22190000 & 1767.0 & 207.60 & Wakeby & 0.232 & 0.272 & 0.883 & 0.203 & 0.002 & 18 \\
\hline 22220000 & 10077.3 & 1110.98 & Wakeby & 0.088 & 0.128 & 0.901 & 0.325 & 0.360 & 19 \\
\hline 22250000 & 14424.7 & 1551.00 & Wakeby & 0.318 & 0.398 & 0.891 & 0.360 & 0.363 & 24 \\
\hline 22500000 & 178453.3 & 11492.77 & Kappa & 0.346 & 0.366 & 0.824 & 0.312 & 0.012 & 28 \\
\hline 22850000 & 9396.6 & 1032.89 & Wakeby & 0.149 & 0.565 & 0.773 & 0.299 & -0.157 & 34 \\
\hline 22900000 & 43376.7 & 2697.00 & Wakeby & 0.332 & 0.417 & 0.822 & 0.276 & -0.065 & 48 \\
\hline 23100000 & 235213.9 & 15098.70 & GEV & 0.397 & 0.397 & 0.863 & 0.336 & 0.204 & 28 \\
\hline 23150000 & 2854.8 & 312.89 & Pearson & 0.339 & 0.453 & 0.826 & 0.320 & 0.034 & 44 \\
\hline 23220000 & 2938.4 & 144.18 & Pearson & 0.256 & 0.308 & 0.783 & 0.332 & -0.070 & 30 \\
\hline 23250000 & 9809.8 & 612.73 & Wakeby & 0.303 & 0.32 & 0.864 & 0.298 & 0.139 & 46 \\
\hline 23300000 & 267392.3 & 14681.06 & Kappa & 0.474 & 0.554 & 0.848 & 0.257 & -0.014 & 36 \\
\hline 23600000 & 281136.9 & 17016.38 & LN2 & 0.567 & 0.585 & 0.848 & 0.284 & 0.044 & 43 \\
\hline 23650000 & 1566.9 & 331.02 & Wakeby & 0.347 & 0.445 & 0.869 & 0.338 & 0.229 & 14 \\
\hline 23700000 & 287336.3 & 19975.07 & GEV & 0.526 & 0.526 & 0.859 & 0.327 & 0.169 & 24 \\
\hline 23710000 & 287405.5 & 19339.39 & GEV & 0.739 & 0.739 & 0.880 & 0.332 & 0.268 & 28 \\
\hline
\end{tabular}

Rev. Ambient. Água vol. 16 n. 6, e2716 - Taubaté 2021 
Table 8. Regionalization models for $\mathrm{Q}_{\text {mean_max }}\left(\mathrm{m}^{3} \mathrm{~s}^{-1}\right)$ as a function of the drainage area (DA) $\left(\mathrm{km}^{2}\right)$ for the $\mathrm{Q}_{\max }$ streamflow hydrologically homogeneous regions of Tocantins River Basin, and their results of the performance evaluation indexes.

\begin{tabular}{cccccccc}
\hline \multirow{2}{*}{ Region } & \multirow{2}{*}{ Regionalization model } & \multicolumn{3}{c}{ Fitting } & \multicolumn{4}{c}{ Cross-validation } \\
\cline { 3 - 8 } & & $\mathrm{R}^{2}$ & RMSE & $\mathrm{c}$ & $\mathrm{R}^{2}$ & RMSE & $\mathrm{c}$ \\
\hline 1 & $\mathrm{Q}_{\operatorname{mean} \text { max }}=1.3233 \mathbf{D A}^{0.6964}$ & 0.869 & 171.25 & 0.898 & 0.768 & 227.90 & 0.811 \\
\hline 2 & $\mathrm{Q}_{\text {mean_max }}=0.2004 \mathbf{D A}^{0.9084}$ & 0.986 & 963.21 & 0.989 & 0.977 & 1228.28 & 0.983 \\
\hline
\end{tabular}

Based on the coupling of the Qmean_max models and regional parameters of the GEV distribution to Equation 3, the regional functions Equation 4 and Equation 5 were obtained for $\mathrm{Q}_{\max }$ homogeneous regions 1 and 2, respectively, to estimate the maximum annual streamflow in $\mathrm{m}^{3} \mathrm{~s}^{-1}$ as a function of the RP (years) and of the drainage area DA $\left(\mathrm{km}^{2}\right)$. These models allow the direct estimation of the $\mathrm{Q}_{\max }$ associated with different return periods for ungauged basins located within the respective homogeneous regions, within the drainage area boundary from 795 to $287,405.5 \mathrm{~km}^{2}$ (Region 1) and from 1585.2 to $20,212.7 \mathrm{~km}^{2}$ (Region 2). Therefore, these regional functions are extremely important tools for the management of water resources in the Tocantins River Basin, especially for planning hydraulic structures. In addition, it can be highlighted that despite the good results obtained in all regionalization models, the use of field monitored data is the best option, since the regionalization process presents uncertainties, as well as any other data simulation process.

$$
\begin{aligned}
& Q_{\text {max }_{-} 1}(R P, D A)=0.766+\frac{0.328}{-0.125} \cdot\left[1-\left(-\operatorname{Ln}\left(1-\frac{1}{R P}\right)\right)^{-0.125}\right] \cdot 1.3233 . D A^{0.6964} \\
& Q_{\text {max }_{-} 2}(R P, D A)=0.849+\frac{0.315}{0.112} \cdot\left[1-\left(-\operatorname{Ln}\left(1-\frac{1}{R P}\right)\right)^{0.112}\right] \cdot 0.2004 . D A^{0.9084}
\end{aligned}
$$

At the end, it is highlighted that the estimates of the regionalization models represent the flow in natural-flow conditions in the basins. This means that the approach will most probably not work or will be misleading if flow regimes analysed are continually changing under maninduced impacts.

\section{CONCLUSIONS}

In the present study, $\mathrm{Q}_{90 \%}, \mathrm{Q}_{95 \%}, \mathrm{Q}_{\mathrm{ltm}}, \mathrm{Q}_{7,10}$, and $\mathrm{Q}_{\max }$ as a function of return period were regionalized. Considering the results, the following conclusions were drawn: i) The nonparametric index-flood method for identification of hydrologically homogeneous regions was adequate for the Tocantins River Basin, presenting results that are consistent with the physiographic reality of the basin; ii) The Wakeby distribution was the one that adjusted to the highest number of $\mathrm{Q}_{7}$ and $\mathrm{Q}_{\max }$ series among the analyzed PDFs, and the GEV distribution was the most robust in relation to $Q_{\max }$, being the only one that adjusted all the series; iii) All fitted models were adequate according to the statistics used; iv) The drainage area as the only explanatory variable was robust for all fittings, which confirms the benefits of its use, especially in terms of ease of use of the generated models; v) The fitted regional models are an alternative for generating data for the poor hydrological monitoring of this important basin of the Brazilian Cerrado; and, vi) The streamflows regionalized in this study are important for water resource management in the Tocantins River Basin because they contribute to several initiatives ranging from the planning of hydraulic structures to the quantitative management of reference streamflows for water-use concessions. 


\section{REFERENCES}

AMORIM, J. D. S.; JUNQUEIRA, R.; MANTOVANI, V. A.; VIOLA, M. R.; MELLO, C. R. D.; BENTO, N. L. Streamflow regionalization for the Mortes River Basin upstream from the Funil Hydropower Plant, MG. Revista Ambiente \& Água, v. 15, n. 3, 2020. https://doi.org/10.4136/ambi-agua.2495

ANA. GEO Brasil recursos hídricos: componente da série de relatórios sobre o estado e perspectiva do meio ambiente no Brasil. Brasília, 2007. 264p.

ANA. Conjuntura recursos hídricos Brasil. Informe anual. Brasília, 2019a. 110p.

ANA. Manual de usos consuntivos da água no Brasil. Brasília, 2019b. 75 p.

ANDERSON, T. W.; DARLING, D. A. A test of goodness of fit. Journal of the American statistical association, v. 49, n. 268, p. 765-769, 1954.

ANEEL. BIG - Banco de Informações de Geração. 2018. Available at: http://www2.aneel.gov.br/aplicacoes/capacidadebrasil/energiaassegurada.asp. Access 15 Oct. 2018.

BAZZO, K. R.; GUEDES, H. A. S.; CASTRO, A. S.; SIQUEIRA, T. M.; TEIXEIRAGANDRA, C. F. A. Regionalização da vazão Q95: comparação de métodos para a bacia hidrográfica do Rio Taquari-Antas, RS. Revista Ambiente \& Água, v. 12, n. 5, p. 855870, 2017. https://doi.org/10.4136/ambi-agua.2032

BESKOW, S.; DE MELLO, C. R.; VARGAS, M. M.; CORREA, L. D. L.; CALDEIRA, T. L.; DURÃES, M. F.; de AGUIAR, M. S. Artificial intelligence techniques coupled with seasonality measures for hydrological regionalization of Q90 under Brazilian conditions. Journal of Hydrology, v. 541, p. 1406-1419, 2016. https://doi.org/10.1016/j.jhydrol.2016.08.046

CAMARGO, A. D.; SENTELHAS, P. C. Avaliação do desempenho de diferentes métodos de estimativa da evapotranspiração potencial no Estado de São Paulo, Brasil. Revista Brasileira de Agrometeorologia, v. 5, n. 1, p. 89-97, 1997.

CASSAlHO, F.; BESKOW, S.; VARGAS, M. M.; MOURA, M. M. D.; ÁVILA, L. F.; MELLO, C. R. D. Hydrological regionalization of maximum stream flows using an approach based on L-moments. Revista Brasileira de Recursos Hídricos, v. 22, 2017. https://doi.org/10.1590/2318-0331.021720160064

CASSALHO, F.; BESKOW, S.; de MELlO, C. R.; de MOURA, M. M.; KERSTNER, L.; ÁVILA, L. F. At-site flood frequency analysis coupled with multiparameter probability distributions. Water resources management, v. 32, n. 1, p. 285-300, 2018. https://doi.org/10.1007/s11269-017-1810-7

CASSALHO, F.; BESKOW, S.; de MELlO, C. R.; de MOURA, M. M. Regional flood frequency analysis using L-moments for geographically defined regions: An assessment in Brazil. Journal of Flood Risk Management, v. 12, n. 2, p. e12453, 2019. https://dx.doi.org/10.1111/jfr3.12453

CHARLES, T. S. Regionalização hidrológica para o estado de Goiás e Distrito Federal. 2020. Dissertação (Mestrado em Engenharia de Sistemas Agrícolas) - Escola Superior de Agricultura Luiz de Queiroz, Universidade de São Paulo, Piracicaba, 2020. https://dx.doi.org/10.11606/D.11.2020.tde-26112020-111327 
CHEN, Y. D.; HUANG, G.; SHAO, Q.; XU, C. Y. Regional analysis of low flow using Lmoments for Dongjiang basin, South China. Hydrological Sciences Journal, v. 51, n. 6, p. 1051-1064, 2006. https://doi.org/10.1623/hysj.51.6.1051

CUPAK, A. Regionalization methods for low flow estimation in ungauged catchments - a review. Acta Scientiarum Polonorum. Formatio Circumiectus, v. 19, n. 1, 2020. https://doi.org/10.15576/ASP.FC/2020.19.1.21

DALRYMPLE, T. Flood frequency methods. US Geological Survey, Water Supply Paper A, v. 1543, p. 11-51, 1960.

DE SOUZA, G. R.; MERWADE, V.; DE OLIVEIRA, L. F. C.; VIOLA, M. R.; DE SÁ FARIAS, M. Regional flood frequency analysis and uncertainties: Maximum streamflow estimates in ungauged basins in the region of Lavras, MG, Brazil. CATENA, v. 197, n. 104970, 2021. https://doi.org/10.1016/j.catena.2020.104970

DINIZ, J. A. O.; MONTEIRO, A. B.; DE CARLO SILVA, R.; PAULA, T. L. F. Mapa hidrogeológico do Brasil ao milionésimo: nota técnica. CPRM, 2014.

ELETROBRAS. Potencial hidrelétrico brasileiro (SIPOT). Relatório Técnico. 2016. Available at: http://www.eletrobras.gov.br/elb/data/Pages/LUMIS21D128D3PTBRIE.htm. Access 19 Sep. 2018.

EMBRAPA. Mapa de solos do Brasil. 2011. Available at: http://mapoteca.cnps.embrapa.br/geoacervo/det_mapa.aspx Access 15 Sep. 2018.

EMBRAPA. Clima. 2018. Available at: https://www.cnpf.embrapa.br/pesquisa/efb/clima.htm Access 05 Oct. 2018.

ESRI. ArcMap. V. 10.1. West Redlands, 2013.

EUCLYDES, H. P.; FERREIRA, P. A.; RUBERT, O. A. V.; SANTOS, R. D. Regionalização hidrológica na bacia do alto São Francisco a montante da barragem de Três Marias, Minas Gerais. Revista Brasileira de Recursos Hídricos, v. 6, n. 2, p. 81-105, 2001.

HAMED, K. H. Trend detection in hydrologic data: the Mann-Kendall trend test under the scaling hypothesis. Journal of hydrology, v. 349, n. 3-4, p. 350-363, 2008. https://doi.org/10.1016/j.jhydrol.2007.11.009

HOSKING, J. R. M.; WALLIS, J. R. Regional Frequency Analysis. Cambridge, UK: Cambridge University Press, 1997. p. 240.

IBGE. Mapeamento do Uso do Solo no Brasil, para os anos 2000, 2010 e 2012. Rio de Janeiro, 2000.

KENDALL, M. G. Rank correlation methods. $4^{\text {th }}$ London: Charles Griffin, 1975.

KOTTEK, M.; GRIESER, J.; BECK, C.; RUDOLF, B.; RUBEL, F. World map of the KöppenGeiger climate classification updated. Meteorologische Zeitschrift, v. 15, n. 3, p. 259263, 2006. https://dx.doi.org/10.1127/0941-2948/2006/0130

KUMAR, R.; CHATTERJEE, C.; KUMAR, S.; LOHANI, A. K.; SINGh, R. D. Development of regional flood frequency relationships using L-moments for Middle Ganga Plains Subzone 1 (f) of India. Water Resources Management, v. 17, n. 4, p. 243-257, 2003. https://doi.org/10.1023/A:1024770124523 
LEME, E. J. A.; CHAUDHRY, F. H. Vazão mínima do vale médio do rio Jaguari Mirim. Revista Brasileira de Recursos Hídricos, v. 10, n. 4, p. 127-136, 2005.

LIMA, J. E. F. W. Situação e Perspectivas Sobre as Águas do Cerrado. Ciência e Cultura, v. 63, n. 3, p. 27-29, 2011. http://dx.doi.org/10.21800/S0009-67252011000300011

LISBOA, L.; MOREIRA, M. C.; SILVA, D. D.; PRUSKI, F. F. Estimativa e regionalização das vazões mínimas e média na bacia do Rio Paracatu. Engenharia na Agricultura, v. 16, n. 4, p. 471-479, 2008.

MANN, H. B. Non-parametric test against trend. Econometrica: Journal of the econometric society, v. 13, p. 245-259, 1945.

MELATI, M. D.; MARCUZZO, F. F. N. Regressões simples e robusta na regionalização da vazão Q95 na Bacia Hidrográfica do Taquari-Antas. Ciência e Natura, v. 38, n. 2, p. 722-739, 2016. http://dx.doi.org/10.21800/S0009-67252011000300011

MORAIS, M. A. V.; VIOLA, M. R.; DE MELlO, C. R.; RODRIGUES, J. A. M.; DE OLIVEIRA, V. A. Regionalization of reference streamflows for the Araguaia River basin in Brazil. Semina: Ciências Agrárias, v. 41, n. 3, p. 829-846, 2020.

MYERS, N.; MITTERMEIER, R. A.; MITTERMEIER, C. G.; DA FONSECA, G. A.; KENT, J. Biodiversity hotspots for conservation priorities. Nature, v. 403, n. 6772, p. 853-858, 2000. https://doi.org/10.1038/35002501

NAGHETTINI, M.; PINTO, E. J. A. Hidrologia Estatística. Belo Horizonte: CPRM, 2007. $552 \mathrm{p}$.

NOTO, L. V.; LA LOGGIA, G. Use of L-moments approach for regional flood frequency analysis in Sicily, Italy. Water resources management, v. 23, n. 11, p. 2207-2229, 2009. https://doi.org/10.1007/s11269-008-9378-x

POOL, S.; VIVIROLI, D.; SEIBERT, J. Prediction of hydrographs and flow-duration curves in almost ungauged catchments: Which runoff measurements are most informative for model calibration? Journal of Hydrology, v. 554, p. 613-622, 2017. https://doi.org/10.1016/j.jhydrol.2017.09.037

PUGLIESI, A.; FARMER, W. H.; CASTELLARIN, A.; ARCHFIELD, S. A.; VOGEL, R. M. Regional flow duration curves: Geostatistical techniques versus multivariate regression. Advances in Water Resources, v. 96, p. 11-22, 2016. https://doi.org/10.1016/j.advwatres.2016.06.008

RODRIGUES, J. A. M.; ANDRADE, A. C. D. O.; VIOLA, M. R.; FERREIRA, D. D.; MELLO, C. R. D.; THEBALDI, M. S. Hydrological modeling in a basin of the Brazilian Cerrado biome. Revista Ambiente \& Água, v. 16, 2021. https://doi.org/10.4136/ambiagua. 2639

SECKIN, N.; HAKTANIR, T.; YURTAL, R. Flood frequency analysis of Turkey using Lmoments method. Hydrological Processes, v. 25, n. 22, p. 3499-3505, 2011. https://doi.org/10.1002/hyp.8077

SILVA, J. M. C. DA; BATES, J. M. Biogeographic patterns and conservation in the South American Cerrado: A tropical savanna hotspot. Bioscience, v. 52, n. 3, p. 225-233, 2002. https://doi.org/10.1641/0006-3568(2002)052[0225:BPACIT]2.0.CO;2 
SILVEIRA, G. L. DA; TUCCI, C. E. M. Monitoramento em pequenas bacias para a estimativa de disponibilidade hídrica. Revista Brasileira de Recursos Hídricos, v. 3, n. 3, p. 97110, 1998.

VEZZA, P.; COMOGLIO, C.; ROSSO, M.; VIGLIONE, A. Low flows regionalization in north-western Italy. Water resources management, v. 24, n. 14, p. 4049-4074, 2010. https://doi.org/10.1007/s11269-010-9647-3

WANG, Y.; LI, J.; FENG, P.; HU, R. A time-dependent drought index for non-stationary precipitation series. Water Resources Management, v. 29, n. 15, p. 5631-5647, 2015. https://doi.org/10.1007/s11269-015-1138-0

WOLFF, W.; DUARTE, S. N.; MINGOTI, R. Nova metodologia de regionalização de vazões, estudo de caso para o Estado de São Paulo. Revista Brasileira de Recursos Hídricos, v. 19, n. 4, p. 21-33, 2014.

ZHANG, Q.; QI, T.; SINGH, V. P.; CHEN, Y. D.; XIAO, M. Regional frequency analysis of droughts in China: a multivariate perspective. Water Resources Management, v. 29, n. 6, p. 1767-1787, 2015. https://doi.org/10.1007/s11269-014-0910-x 


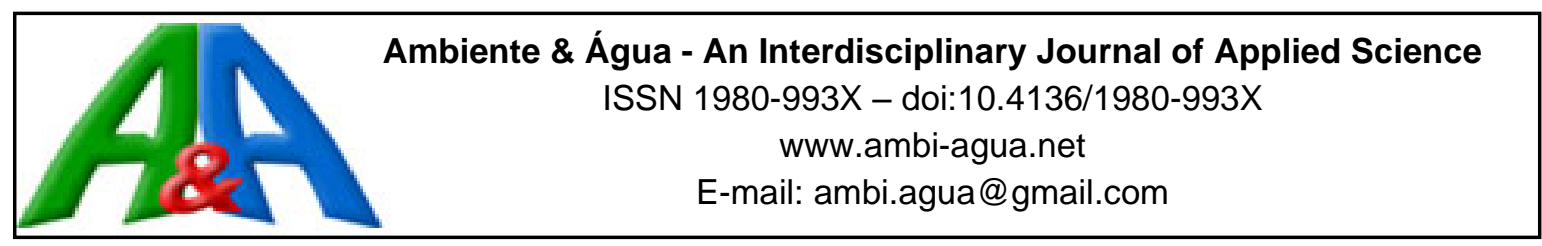

\title{
Removal of nutrients from aquaculture residual water: A review
}

\author{
ARTICLES doi:10.4136/ambi-agua.2747
}

Received: 07 May 2021; Accepted: 26 Oct. 2021

\author{
Jéssica Mendonça Ribeiro Cargnin (iD; Jair Juarez João*(i) \\ Centro Tecnológico. Universidade do Sul de Santa Catarina (UNISUL), Avenida José Acácio Moreira, $n^{\circ} 787$, \\ CEP: 88704-900, Tubarão, SC, Brazil. E-mail: jessica.mribeiiro@gmail.com \\ *Corresponding author. E-mail: jair.joao@unisul.br
}

\begin{abstract}
Aquaculture plays an important role in providing protein-rich foods, meeting the growing demand for fish. However, aquaculture is a potentially polluting activity, especially with regard to water pollution, due to the improper disposal of wastewater from the production process. Aquaculture wastewater is rich in nutrients (ammonia, nitrate, nitrite and phosphorus) and organic matter, and is commonly discharged into the environment without proper treatment. This can cause a series of environmental impacts and aggravate the current water crisis. Due to the importance and need to reduce environmental impacts, plan the use of water resources and achieve an efficient and sustainable production process, many researchers have focused their studies on effluent treatment techniques designed to remove these nutrients. This article therefore presents an updated review of the main physicochemical and biological techniques used in the removal of nutrients, which can mitigate environmental problems arising from aquaculture activities and contribute to the sustainability of the activity.
\end{abstract}

Keywords: biological removal, nitrogen compounds, sustainable activity.

\section{Remoção de nutrientes da água residual da aquicultura: uma revisão}

\section{RESUMO}

A aquicultura é uma das atividades que desempenha um papel importante no abastecimento de alimentos ricos em proteínas, atendendo à crescente demanda por pescados. No entanto, a aquicultura é considerada uma atividade potencialmente poluidora, principalmente ao que se refere a poluição hídrica, devido ao descarte indevido de efluentes provenientes do processo produtivo. Os efluentes aquícolas são ricos em nutrientes (amônia, nitrato, nitrito e fósforo) e matéria orgânica, e comumente são lançados no meio ambiente sem o devido tratamento, podendo causar uma série de impactos ambientais e agravar a crise hídrica vivenciada na atualidade. Devido à importância e à necessidade de reduzir os impactos ambientais, planejar de forma eficiente a utilização dos recursos hídricos e alcançar um processo produtivo eficiente e sustentável, muitos pesquisadores têm focado seus estudos em técnicas de tratamento de efluentes voltadas para remoção desses nutrientes. Sendo assim, este artigo visa apresentar uma revisão atualizada das principais técnicas físico-químicas e biológicas, utilizadas na remoção de nutrientes, que podem mitigar os problemas ambientais provenientes da atividade aquícola e contribuir para sua sustentabilidade.

Palavras-chave: atividade sustentável, compostos de nitrogênio, remoção biológica.

This is an Open Access article distributed under the terms of the Creative Commons Attribution License, which permits unrestricted use, distribution, and reproduction in any medium, provided the original work is properly cited. 


\section{INTRODUCTION}

Fishing is one of the oldest activities practiced by man to obtain protein-rich foods. Over the years, fishing activity has undergone a series of technological advances, evolving from artisanal activity to industrial activity. As a result of industrial fishing and the need to meet the growing world demand for food, the supply of fish in natural environments has decreased considerably, causing a decline in activity income. Thus, the sufficient supply of proteins to meet the world demand has become one of today's great challenges (Crab et al., 2007; Nie et al., 2020).

The decline in fishing income and population expansion have driven the growth of aquaculture, which in recent years has played an important role in the global supply of proteinrich foods (Hlordzi et al., 2020; Huang et al., 2020; Manju et al., 2009). According to the Food and Agriculture Organization of the United Nations (FAO, 2020), in 2018 the world production of fish was 179 million tons, of which 82 million tons came from aquaculture. That was responsible for $46 \%$ of total fish production and 52\% of fish production for human consumption. Future projections suggest that, in order to keep up with population growth and to meet the growing demand for fish, aquaculture production should increase, on average, between $60 \%$ to $100 \%$ in the next 20-30 years (FAO, 2020; Turcios and Papenbrock, 2014; Webb et al., 2012).

The need to achieve food security and to produce more and more protein foods has driven the intensification and rapid expansion of aquaculture activity (Manju et al., 2009). However, as in all production processes, the expansion of activity has caused a series of environmental impacts, mainly those related to the improper discharge of untreated wastewater, contributing to the pollution of water resources (Chávez-Crooker and Obreque-Contreras, 2010; Hlordzi et al., 2020; Turcios and Papenbrock, 2014). In addition to causing the degradation of water resources and a series of imbalances in aquatic life, aquaculture is an activity that requires large volumes of water. In traditional shrimp farms, for example, with ponds of up to 10 hectares and which have the capacity to produce more than 10 tons of shrimp/ha per year, between 20 and 64 cubic meters of water are needed for each $1 \mathrm{~kg}$ of shrimp produced (de Melo Filho et al., 2020; Krummenauer et al., 2014), because there is a need for frequent water changes in the production tanks ( 5 to $20 \%$ of the total volume/day) for the good development of the animals. Water resources are of paramount importance for the development of any economic activity and, currently, there are serious problems related to water scarcity in the world, and the limitation of this resource is one of the biggest challenges facing aquaculture today (Chen $e t$ al., 2014; de Melo Filho et al., 2020; Krummenauer et al., 2014; Manju et al., 2009).

One of the main problems related to wastewater from aquaculture activity involves the accumulation of nitrogen compounds (ammonia, nitrite and nitrate), phosphorus, solids and organic matter (Crab et al., 2007; Mook et al., 2012; Turcios and Papenbrock, 2014). These nutrients mainly come from animal feed. According to Mangarengi et al. (2020), from the food offered to the animals raised, only $30 \%$ of the feed is absorbed by their organism, while $70 \%$ is not consumed and is excreted, contributing to the accumulation of nutrients in the tanks. The effluents generated in aquaculture activity differ in quality and quantity of their components, according to the cultivated species and the type of cultivation system adopted. The methods of intensive and semi-intensive cultivation require a greater amount of inputs, such as food and chemical additives, which end up favoring the accumulation of nutrients in the production tanks and generating a large amount of solid waste (Chatla et al., 2020; Mangarengi et al., 2020).

In addition to environmental impacts, such as eutrophication of water bodies, reduction of dissolved oxygen, imbalance in ecosystems, death of aquatic species and contamination of groundwater, which are caused by the improper disposal of untreated wastewater, the accumulation of nutrients and residual organic matter in the cultivation tanks can harm 
aquaculture production. The poor quality of the water in the tanks, caused mainly by the accumulation of nutrients, make these environments conducive to the proliferation of pathogens, contributing to weight loss, malformation, intoxication, stress and death of the cultivated animals (Hlordzi et al., 2020; Ni et al., 2020; Song et al., 2011; Zoppas et al., 2016). In addition to environmental and productive problems, wastewater may contain other contaminants, such as heavy metals, hormones or antibiotics, which can also cause problems to human health (Chatla et al., 2020; Turcios and Papenbrock, 2014).

Considering the socio-environmental and economic impacts caused by aquaculture, it is extremely important that wastewater from aquaculture receive adequate treatment before being released into the environment, thus reducing the negative environmental impacts generated and bringing the activity closer to a more sustainable productive process. Thus, the objective of the present article was to conduct a review of the main techniques used in the treatment of wastewater from aquaculture, especially fish and shrimp farming activities.

\section{METHODS, RESULTS AND DISCUSSION}

The most cited words in the analyzed documents are shown in Figure 1. First, it displays the number of occurrences of the words by the size of the circles, in which the larger the circle, the more the word was mentioned, as well as the year of occurrence represented by the color.

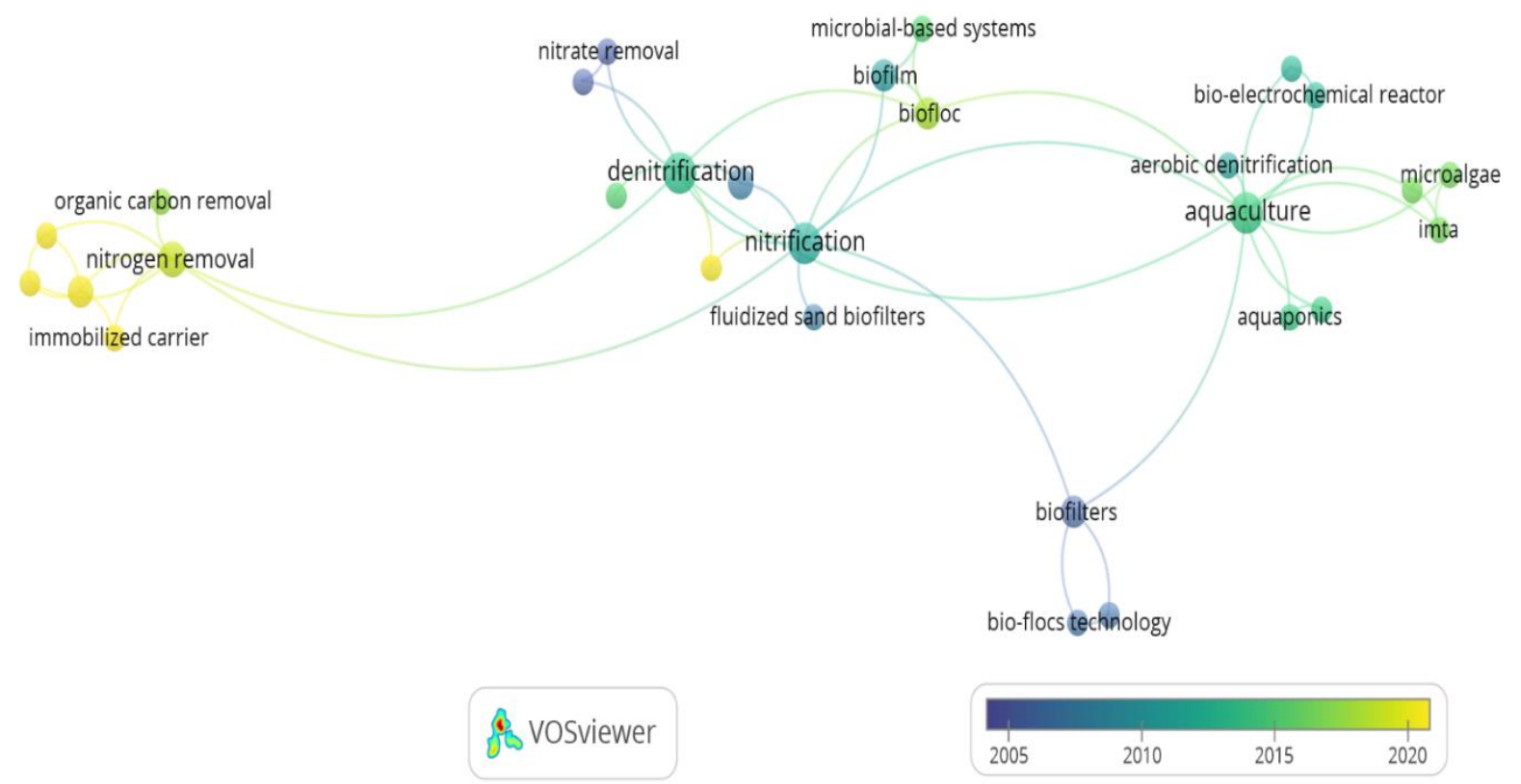

Figure 1. Analysis of the occurrence of words.

Aquaculture is constantly growing and has been causing a series of environmental problems. With worsening availability of drinking water in the world, it is extremely important and urgent that the activity is developed in a sustainable way. For this, it is necessary to constantly search for techniques to remove nutrients and for more efficient cultivation systems that can provide a reduction in environmental impacts, as well as the treatment and reuse of water.

According to Figure 1, it is possible to see that over the last decades the search for wastewater treatment techniques generated in aquaculture has increased. Between 2005 and 2010, interest in nutrient removal techniques such as nitrate, nitrite and ammonia increased, since the most cited words in the literature in this period refer to nitrate removal, biofloc technology and aquaculture, being the physicochemical processes, most reported in the literature. 
After 2010, the number of articles in the literature that showed interest in biological treatment techniques, mainly for the removal of nitrogenous compounds, increased. Most of the studies highlight the most sustainable and economically viable technologies, such as biological denitrification, integrated multi trophic aquaculture (IMTA) systems, as well as the use of microalgae, aquaponics and wetlands to remove nutrients.

Currently, there are several technologies that are used to remove nutrients such as nitrogen compounds, organic matter and phosphorus from wastewater generated in aquaculture. Among these techniques, physicochemical and biological processes continue to stand out.

There are several techniques for removing nutrients from wastewater by means of aquaculture activities, and the physicochemical and biological methods are among them. Biological methods have aroused the interest of researchers from all over the world for presenting satisfactory results in the removal of nutrients, in addition to the low operational cost when compared with physicochemical methods (Mook et al., 2012).

When analyzing the documents selected for the preparation of this review, the huge interest of researchers in developing and optimizing technologies that are efficient in removing contaminants from wastewater generated in aquaculture was evident, mainly in technologies based on biological removal, since most of the studies analyzed focus on biological treatment to remove nutrients that enable their disposal without damaging the environment and/or that allow the reduction of water exchange in the cultivation tanks, thus minimizing the consumption of drinking water in aquaculture activity. Still, it is important to emphasize that aquaculture encompasses a series of production activities, such as shrimp farming, fish farming and frog farming, among others. The wastewaters from these activities have different characteristics and their pollutants differ in quality and quantity. It is necessary that the methods used for the treatment of wastewater are evaluated according to the needs of each activity.

\subsection{Physicochemical treatment techniques used to remove nutrients from aquaculture wastewater}

Before being released into the environment, effluents must undergo a treatment process to remove contaminants that can cause problems to ecosystems. The physicochemical treatments of wastewater require certain steps to promote the removal of contaminants, such as coagulation, flocculation, grating, filtration, $\mathrm{pH}$ correction, ion exchange, disinfection, oxidation, chemical transformation, reverse osmosis, among others (Mook et al., 2012).

Normally, wastewater is subjected to physicochemical treatments to control pollutants that have not been removed by conventional biological processes. Among the physicochemical processes used to remove pollutants, the adsorption method is one of the most used in aquaculture to remove organic contaminants, thus promoting the recovery and purification of the effluent.

Adsorption is the adhesion of one or more substances from a gas, liquid or solid (adsorbate) to an insoluble solid surface (adsorbent). In this process, the contaminant removal mechanism is based on the imbalance of attractive forces present on the surface of the adsorbent solid. Thus, when the adsorbent comes into contact with the adsorbates, there is an interaction between the fields of force of the solid and liquid surfaces, balancing the forces, attracting and retaining the molecules on the surface of the adsorbent (Maroneze et al., 2014).

Factors such as surface area, porosity, chemical surface of the adsorbent compound, molecular weight, molecular size and geometry, solubility, polarity of the adsorbate, interaction between the adsorbent and the adsorbate, contact time, $\mathrm{pH}$ and temperature of the medium can interfere with the adsorption process (Bansal and Goyal, 2005). According to Sauer (2006), the structure of the adsorbent is one of the most important factors to be considered, since compounds with smaller molecular diameters have greater adsorption capacity.

Several materials are used as adsorbents to remove contaminants from wastewater, such as alumina, coal and activated silica, synthetic polymers, and some natural adsorbents. 
However, depending on the adsorbent material used, the process becomes economically unfeasible for the treatment of effluents, as in the case of the use of ion exchange resins due to its limited application and high cost (Scheeren et al., 2011).

One of the most used adsorbent materials is activated carbon, due to its large porous surface area and high adsorption capacity. In addition, it has high thermal stability, low acid/base reactivity and can be recovered after saturation and later reused in the process (Mook et al., 2012; Scheeren et al., 2011).

Another method that can be used for wastewater treatment is membrane filtration treatment. Membranes are barriers that allow separating two phases and restrict the selective passage of materials, according to their size, shape and characteristics. Due to the different dimensions of the pores, membranes are used both to remove solids, viruses and bacteria, and to remove ions of different molecular weights (Freddi, 2019). Membranes are produced using organic polymers and inorganic polymers based on metals, glass or ceramic materials, and can be classified as isotropic and anisotropic, according to their morphology, and dense or porous, according to the characteristics of their surface. In general, despite their higher production cost, membranes made from inorganic materials are more used than membranes based on organic materials, as they have a longer service life and allow for more efficient cleaning (Souza et al., 2021).

The use of separation processes with filtering membranes can be one of the solutions for the treatment of aquaculture wastewater, since filtration systems such as microfiltration (MF), ultrafiltration (UF), nanofiltration (NF) and reverse osmosis (OR) are able to remove organic and inorganic contaminants, as well as bacteria, protozoa and viruses, enabling the reuse of water in the process (Freddi, 2019). Although the OR process is widely used in desalination processes, it can also be applied in wastewater treatment and water reuse to remove phosphates, calcium, heavy metals, color and organic matter. In the filtration process, the medium to be treated passes through the membrane due to the pressure difference between its sides, retaining the desired contaminant (Pires, 2017). The filtration systems differ from each other through the pore sizes of the membranes as follows: for MF, the membranes have pores from 0.1 to 10 microns; for UF, they have pores from 0.1 to 0.01 microns; for NF, pores from 0.01 to 0.035 microns, and for OR they have pores of 0.0001 to 1 micron. The filtration systems also can be classified as a function of the pressure required of the retained material and the retention mechanism, with the pressure used in each of the processes in accordance with the pore size of each membrane (Souza et al., 2021).

Although many types of filters are used as filter media in wastewater treatments, one of the advantages of using membranes is their ability to retain contaminants on a molecular scale, such as salts and ions. In addition, they have other advantages such as energy savings, the technology is clean and easy-to-operate, and they enable the recovery of products that have high added value and can be applied in hybrid treatment processes (Souza et al., 2021).

Regarding the OR process, Mook et al. (2012) highlight as advantages high efficiency in the permeability of selective ions, low production cost, potential to remove ions, proteins and organic compounds and also the fact that normally there is no accumulation of products in the membrane in the process. As a disadvantage, it is a costly process, mainly related to energy and, in some cases, the membrane may become encrusted, impairing its performance and making the process more expensive.

Expandable granular biofilters (EGBs) are another method that can be used to remove contaminants from aquaculture wastewater, especially in partial or total water recirculation (RAS) systems. They are widely used in fish farming, mainly in the removal of solids and nutrients (Kubitza, 2006; Turcios and Papenbrock, 2014) and can operate both as physical and biological filters. Expandable granular filters use low-density floating spheres such as plastic or polystyrene spheres with diameters ranging from 1 to 3 millimeters $(\mathrm{mm})$ and are operated 
in downward flows. They are sized as a physical filter (clarifier) to remove solids and simultaneously facilitate the growth of nitrifying bacteria, which adhere to the spheres and are capable of removing nutrients dissolved in the medium through the biofiltration process. Usually, this type of filter operates as a physical filter. The removal process of this type of filter is similar to sand filters; however, filters with floating spheres do not have problems with hardening, which affect sand filters when exposed to high organic loads (de Miranda, 2012). The wastewater is included in the filter, with a downward flow, and the solids are retained through the layers of spheres, which, due to their porosity, prevent the passage of contaminants. With a filtration cycle, it is possible to remove about $50 \%$ of fine solids and practically all solid material above $50 \mathrm{~mm}$. When several filtration cycles are carried out, it is possible to obtain the complete removal of solids and the biofiltration processes are activated (Steicke et al., 2007).

In the biofiltration process, each sphere is coated with a thin film of bacteria, heterotrophic and autotrophic nitrifying, which promote the retention of nutrients, such as ammonia, nitrate and nitrite, as the water passes through the filter. Upon reaching the saturation of the spheres, the cleaning of the bed can be carried out by mechanical, hydraulic or pneumatic means, releasing solids and the excess bioflakes, thus restoring the filtration capacity. According to Turcios and Papenbrock (2014), the removed sludge has potential applications for composting, vermiculture and fertilizers in agriculture, due to the high concentration of organic matter and nutrients. The disadvantage of this method is related to its high cost, since it requires a significant capital investment and demands a high consumption of energy and maintenance.

\subsection{Biological treatment techniques used to remove nutrients from aquaculture wastewater}

Biological processes are among the most studied treatment techniques today, due to the low cost of installation and operation, when compared to physicochemical treatments (Mook et al., 2012; Scheeren et al., 2011).

Biological processes are widely used to remove nutrients from effluents from different agro-industrial activities. Normally, the processes of removal of nitrogen compounds by the conventional method occur in two separate units, which are based on the combination of aerobic and anoxic processes, and basically consist of the nitrification and denitrification processes, being among the main natural processes involved in the biogeochemical cycle of nitrogen, which are carried by autotrophic and heterotrophic bacteria, respectively (Alves et al., 2018).

The nitrification process is carried out by means of two groups of aerobic bacteria, characterized by the obtention of their energy through the oxidation of inorganic compounds $\left(\mathrm{NH}_{4}\right.$ and $\left.\mathrm{NO}_{2}\right)$. As a carbon source, they use inorganic carbon $\left(\mathrm{CO}_{2}\right)$ and, as an electron acceptor, they use oxygen $\left(\mathrm{O}_{2}\right)$. These bacteria are responsible for nitritation, in which the oxidation of ammonia to nitrite occurs, generating hydroxylamine $\left(\mathrm{NH}_{2} \mathrm{OH}\right)$ as an intermediate product, and for nitration, in which the oxidation of nitrite to nitrate occurs (Zoppas et al., 2016).

The group formed by bacteria of the genus Nitrosomonas, Nitrosococcus and Nitrospira are responsible for the oxidation of ammonia to nitrite, while the group formed by bacteria of the genus Nitrospira, Nitrobacter, Nitrospina and Nitrococcus promote the oxidation of nitrite to nitrate. The oxidation reactions of ammonia to nitrite and the oxidation of nitrite to nitrate are represented in Equations 1 and 2, respectively (Alves et al., 2018).

$$
\begin{aligned}
& \mathrm{NH}_{4}^{+}+1,5 \mathrm{O}_{2} \rightarrow 2 \mathrm{H}^{+} \mathrm{H}_{2} \mathrm{O}+\mathrm{NO}_{2}^{-}+\text {energy } \\
& \mathrm{NO}_{2}^{-}+0,5 \mathrm{O}_{2} \rightarrow \mathrm{NO}_{3}^{-}+\text {energy }
\end{aligned}
$$

As they are bacteria that need oxygen, dissolved oxygen (DO) in the medium becomes a limiting factor in the nitrification process, as well as the temperature and $\mathrm{pH}$ can inhibit the 
growth of bacteria and interfere in the process of removing contaminants. According to Crab et al. (2007), low dissolved oxygen concentrations $\left(<2 \mathrm{mg} \mathrm{L}^{-1}\right)$ can partially or totally limit the development and activity of nitrifying bacteria.

Regarding temperature, Zoppas et al. (2016) mention that temperatures below $10^{\circ} \mathrm{C}$ and above $35^{\circ} \mathrm{C}$ significantly affect the growth rate of nitrifying bacteria, while temperatures between $25^{\circ} \mathrm{C}$ and $35^{\circ} \mathrm{C}$ are considered optimal temperatures and favor their development.

Freddi (2019) reports that the most favorable $\mathrm{pH}$ ranges for the development of nitrifying bacteria are between 6.5 and 8.0. The $\mathrm{pH}$ is an important factor for determining the balance between ionized and non-ionized substances and favoring or inhibiting the growth of ammonia oxidizing bacteria $(\mathrm{AOB})$ and nitrite oxidizing $(\mathrm{NOB})$, since a $\mathrm{pH}$ greater than 8 favors the formation of ammonia and, consequently, the development of $\mathrm{AOB}$, and at a $\mathrm{pH}$ lower than 6 inhibits the activity of both bacteria.

The denitrification processes, in turn, are anoxic processes; that is, they occur in the absence of oxygen but in the presence of nitrates, in which nitrates replace oxygen and are used as electron acceptors by heterotrophic bacteria. The process promotes the reduction of nitrate to nitrogen gas $\left(\mathrm{N}_{2}\right)$, and is carried out by bacteria of the genera Alcaligenes, Archromobacter, Thiosphaera, Rhodopseudomonas, Methanofollis sp., Bacillus sp., Pseudomonas sp., Paracoccus sp. and Enterococcus, which use nitrate in their respiratory process, removing nitrate from the medium (Deng et al., 2021; John et al., 2020). As in nitrification processes, denitrification processes can also be affected by some operational factors, such as $\mathrm{pH}$, temperature, amount of organic carbon $(\mathrm{C} / \mathrm{N}$ ratio) present in the medium and the concentration of DO, since the denitrification is anoxic and DO concentrations above $2 \mathrm{mg} \mathrm{L}^{-1}$ significantly limit the development and activity of denitrifying bacteria, which can lead to the accumulation of intermediate substances such as nitrite, nitric oxide and nitrous oxide (Zoppas et al., 2016).

In biological treatments, operating costs are essentially related to aeration needs in the nitrification step and the addition of an external source of organic carbon in the heterotrophic denitrification step (Zoppas et al., 2016). Organic carbon concentrations are important for the denitrification process to take place, since bacteria use organic carbon as an energy source. In wastewater with a low carbon/nitrogen ratio (less than 2.5), it is necessary to add an external organic carbon source (Zhao et al., 2018).

Many works have mentioned the Anammox (anaerobic ammonium oxidation) processes as a very promising process for the removal of nutrients from aquaculture wastewater, which can also be used in the treatment of sanitary effluents, industrial effluents, swine effluents, saline water treatment and slurry. In the Anammox process, the oxidation of ammonia and the reduction of nitrite occur simultaneously in an anaerobic medium, obtaining $\mathrm{N}_{2}$ as the final substance (Scheeren et al., 2011; van Rijn et al., 2006). This process is carried out by Anammox bacteria, which belong to the Planctomycetes phylum and has eleven genera: Pirellula, Rhodopirellula, Blastopirellula, Planctomyces, Gemmata, Isosphaera, Brocadia, Kuenenia, Scalindua, Anammoxoglobus and Asian Jettenia. These bacteria have a low growth rate, strong affinity with nitrite and ammonium, are found in wastewater and also in natural systems, such as mangroves, the ocean, estuarine sediments and freshwater lakes. However, due to their low rate of duplication, a large amount of inoculum is needed to carry out aquaculture wastewater treatment (Chávez-Crooker and Obreque-Contreras, 2010; Ni et al., 2020; Scheeren et al., 2011).

Anammox processes are also influenced by factors such as temperature, $\mathrm{pH}, \mathrm{DO}, \mathrm{C} / \mathrm{N}$ ratio and concentration of nitrogen present in the medium. According to Scheeren et al. (2011), the Anammox process is favored at temperatures between $25^{\circ} \mathrm{C}$ and $40^{\circ} \mathrm{C}$, which may vary according to the genus of bacteria used, and at low temperatures the bacterial activity is considerably reduced. The ideal $\mathrm{pH}$ range for the development of bacteria is between 6.5 and 8.5 , while in very acidic or very basic $\mathrm{pH}$ ranges, they can favor the increase in the concentration 
of ammonia and nitrous acid, which inhibits the development of Anammox bacteria.

Ni et al. (2020) report that the anammox process is favored in wastewater that has a low carbon/nitrogen $(\mathrm{C} / \mathrm{N})$ ratio; that is, with a high concentration of ammonium and a low concentration of organic matter, thus reducing operating costs with the addition of an external carbon source, used for the growth of heterotrophic bacteria in the conventional biological denitrification method.

For Alves et al. (2018), the main advantages of using the Anammox process to remove nitrogenous compounds are related to robustness, lower oxygen consumption, which is consumed when there is no source of nitrite, as well as the fact that it does not need external sources of carbon and its versatility. The Anammox process is capable of removing 10 times greater loads of contaminants and consumes about 60\% less energy when compared to conventional biological removal processes (Scheeren et al., 2011).

Another process of nitrification and biological denitrification that has attracted the attention of researchers is the simultaneous nitrification-denitrification (SND) process, an alternative for optimizing the process for removing nitrogenous compounds. Unlike conventional denitrification and Anammox processes, in this process, nitrification and denitrification occur simultaneously, in the same reactor and under the same operating conditions. SND removal is performed by heterotrophic aerobic nitrification and denitrification (HNDA) bacteria (Deng et al., 2021), and the removal process occurs within the biofilm due to the biomass oxygen gradient, which favors the simultaneous propagation of the bacteria nitrifying and denitrifying due to uneven oxygen distribution. Thus, nitrifying bacteria are found in areas of the biofilm that have the highest concentration of DO, while denitrifying bacteria are found in areas where OD is limited (Zoppas et al., 2016).

HNAD bacteria have a higher growth rate and higher nitrogen removal capacity when compared to autotrophic bacteria and are more tolerant to different conditions and environments, favoring a more efficient removal of contaminants. Some strains of HNAD bacteria have been extensively studied and have been found and isolated from different environments, such as Acinetobacter, Bacillus, Cupriavidus, Halomonas, Klebsiella, Marinobacter, Pseudomonas and Photobacterium (Huang et al., 2020). According to Deng et al. (2021), HNAD bacteria are not limited to the presence of dissolved oxygen in aquaculture systems, presenting high denitrification efficiency. However, despite being able to reach the stationary phase in 24 hours with an average efficiency of $90 \%$ of removal of nitrogen, for the complete process of nitrification to occur, the HNAD bacteria require a longer period, which can reach weeks.

To obtain a complete simultaneous removal process, it is necessary that the nitrification rate and the denitrification rate are similar. For this, it is necessary that the organic substrate is a substance with low degradability so that the process is not compromised, since nitrification is generally slower compared to denitrification. In addition, factors such as temperature, $\mathrm{pH}, \mathrm{DO}$, $\mathrm{C} / \mathrm{N}$ ratio, form of aeration and age of the sludge can also interfere with the efficiency of removal of contaminants (Zoppas et al., 2016).

As an advantage, the use of simultaneous nitrification and denitrification processes promotes a reduction in the surface used, which translates into savings in space and infrastructure. In addition, COD and nitrogen removal are one of the advantages of these systems, providing a 30-40\% reduction in electrical energy consumption in aeration when compared to conventional nitrification and denitrification processes (Deng et al., 2021).

As a way to optimize the process of nitrification and biological denitrification, many researchers have turned their studies to the application of bacterial consortia to remove nutrients from aquaculture wastewater. Bacterial consortia consist of the use of two or more populations of bacteria of different species that act together, in a combination in which all are benefited due to the activities practiced by each species. However, the efficiency of the process depends a lot 
on finding the right bacteria that have the capacity to remove contaminants, so that the degradation process takes place (John et al., 2020).

Studies by Huang et al. (2020), in which 25 strains of bacteria were tested, showed that most of the tested bacterial consortium presented removal between $45-55 \%$ of $\mathrm{NH}_{4}{ }^{+}-\mathrm{N}$, while the single strains showed removal between $35-45 \%$ of ammonia after 12 hours of cultivation, which makes it evident that bacterial consortium are more efficient at removing ammonia from wastewater. Effective results regarding the use of a bacterial consortium have also been described by John et al. (2020), who confirmed the efficiency of the bacterial consortium in converting ammonia into nitrite and less toxic nitrate, reaching a fish survival rate in the tanks of $97.2 \pm 0.58 \%$, while in the control tanks, without addition of bacteria, fish died from ammonia toxicity.

For aquaculture to be a sustainable activity, the treatment of wastewater from the production process is a mandatory requirement. Over the years, a researcher has focused on several ways to optimize biological processes, in order to achieve higher percentages of removal of pollutants from aquaculture wastewater (Mook et al., 2012). Some studies are shown in Table 1.

\section{CONCLUSION}

Aquaculture contributes to the world's food security, meeting the growing demand for protein-rich foods. However, the activity is considered one of the main causes of water pollution, because aquaculture generates wastewater rich in nutrients such as nitrogen compounds and organic material, which lead to a series of environmental impacts when released without prior treatment into the receiving water bodies.

Over the years, in order to reduce the environmental impacts of aquaculture activity, research has focused on the development of technologies capable of efficiently removing pollutants present in wastewater. Among the many technologies studied, present in the analyzed literature, it was evident that there was a growing interest in biological technologies and in ways to optimize these processes, in order to increase biological efficiency in the removal of contaminants for aquaculture wastewater treatments. The preference for technologies occurs mainly because they are lower in cost when compared to the physical chemical processes. 
Table 1. Techniques for removing nitrogenous compounds from aquaculture wastewater.

\begin{tabular}{|c|c|c|c|}
\hline $\begin{array}{l}\text { Document } \\
\text { Type }\end{array}$ & Techniques covered & Main results & Reference \\
\hline Review & $\begin{array}{l}\text { Integrated Multi Trophic } \\
\text { Aquaculture (IMTA); } \\
\text { Nitrification and } \\
\text { denitrification; Anammox } \\
\text { (Anaerobic Oxidation of } \\
\text { Ammonia); Wetlands }\end{array}$ & $\begin{array}{l}\text { This review addresses methods such as IMTA, biological } \\
\text { nitrogen removal through nitrification and denitrification, } \\
\text { anammox and wetlands, techniques that are being studied to } \\
\text { increase the efficiency in removing nitrogen and other } \\
\text { nutrients in situ from cultivation sites. }\end{array}$ & $\begin{array}{l}\text { Chávez-Crooker and Obreque-Contreras } \\
\text { (2010) }\end{array}$ \\
\hline Research & $\begin{array}{l}\text { Biological nitrification } \\
\text { and denitrification using a } \\
\text { reactor in a biofloc } \\
\text { system }\end{array}$ & $\begin{array}{l}\text { The nitrogen removal process took place over the } \\
\text { experimental period. On the } 4 \text { th day, nitrogen removal became } \\
\text { stable with an average efficiency of } 71.28 \pm 5.28 \% \text {. } \\
\text { Operational variables were controlled throughout the system, } \\
\text { such as pH at } 8.26 \pm 0.1 \text {, temperature at } 28.7 \pm 1.1^{\circ} \mathrm{C} \text { and } \\
\text { dissolved oxygen at } 0.51 \pm 0.41 \mathrm{mg} \mathrm{L}^{-1} \text {. }\end{array}$ & de Melo Filho et al. (2020) \\
\hline Review & $\begin{array}{l}\text { Simultaneous biological } \\
\text { nitrification and } \\
\text { denitrification }\end{array}$ & $\begin{array}{l}\text { Review on the process of biological nitrogen removal from } \\
\text { wastewater, addressing the main parameters that influence the } \\
\text { removal of the contaminant, emphasizing the simultaneous } \\
\text { process of nitrification and denitrification. }\end{array}$ & Zoppas et al. (2016) \\
\hline Review & $\begin{array}{l}\text { Sequencing batch reactor } \\
\text { for biological treatments }\end{array}$ & $\begin{array}{l}\text { This review paper discusses the technical description and } \\
\text { operational flexibility of the SBR for the treatment of a wide } \\
\text { range of effluents under different operating conditions, } \\
\text { together with its modifications that can increase the } \\
\text { effectiveness of the SBR systems in the removal of nitrogen } \\
\text { and phosphorus. }\end{array}$ & Shing and Srivastava (2011) \\
\hline Review & $\begin{array}{l}\text { Aquaculture } \\
\text { Recirculation System } \\
\text { (RAS); Integrated Multi } \\
\text { Trophic Aquaculture } \\
\text { (IMTA); Biofloc } \\
\text { Technology (BFT) }\end{array}$ & $\begin{array}{l}\text { In this review, some aquaculture wastewater treatment } \\
\text { techniques were addressed, such as RAS, IMTA and BFT to } \\
\text { reduce pollution and reuse water. }\end{array}$ & Chatla et al. (2020) \\
\hline
\end{tabular}

Continue...

Rev. Ambient. Água vol. 16 n. 6, e2747 - Taubaté 2021 


\section{Continued...}

\begin{tabular}{|c|c|c|c|}
\hline Research & $\begin{array}{l}\text { Nitrification and } \\
\text { denitrification through a } \\
\text { bacterial consortium }\end{array}$ & $\begin{array}{l}\text { The results showed that the majority of microbial consortia } \\
\text { showed higher efficiency of } \mathrm{NH}_{4}^{+}-\mathrm{N} \text { removal }(45-55 \%) \text { than } \\
\text { single strains }(35-45 \%) \text { after } 12 \mathrm{~h} \text {. In nitrite removal, bacterial } \\
\text { consortia showed a higher removal rate }(58 \%) \text { after } 16 \text { hours, } \\
\text { while single strains showed less efficiency }(30-35 \%) \text {, } \\
\text { suggesting that the removal of ammonia and nitrite by } \\
\text { bacterial consortium is more effective. }\end{array}$ & Huang et al. (2020) \\
\hline Research & $\begin{array}{l}\text { Immobilization of } \\
\text { nitrifying bacteria pools } \\
\text { in wood particles }\end{array}$ & $\begin{array}{l}\text { The nitrifying bacterial consortium was immobilized on the } \\
300-1500 \mu \mathrm{m} \text { particle substrate. The mean removal of TAN } \\
\text { during immobilization was } 3.5 \pm 1.52 \mathrm{mg} \mathrm{L}^{-1} \text { day }^{-1} \text {, while } \\
\mathrm{NO}_{2}-\mathrm{N} \text { and } \mathrm{NO}_{3}-\mathrm{N} \text { were below the detectable limits. The } \\
\text { wood dust sampled on days } 4 \text { and } 5 \text {, showed a potential for } \\
\text { removal of TAN of } 5.67 \pm 1.6 \mathrm{mg} \mathrm{L}^{-1} \text { day }^{-1} \text { and } 5.23 \pm 1.91 \\
\mathrm{mg} \mathrm{L}^{-1} \text { day }^{-1} \text { respectively. There was no significant increase in } \\
\text { the rate of removal of TAN by NBC after } 4 \text { days of } \\
\text { immobilization. }\end{array}$ & Manju et al. (2009) \\
\hline Review & $\begin{array}{l}\text { Immobilization of } \\
\text { anaerobic ammonium } \\
\text { oxidation bacteria; } \\
\text { Anammox (anaerobic } \\
\text { ammonium oxidation) }\end{array}$ & $\begin{array}{l}\text { This review presents the opportunities and challenges found in } \\
\text { the use of cellular immobilization to increase the efficiency in } \\
\text { the removal of nitrogen from wastewater by anammox } \\
\text { bacteria, as well as the existing technologies for anammox } \\
\text { immobilization. Evaluates the sustainability of different gel } \\
\text { carriers and the application of immobilized anammox. }\end{array}$ & Ni et al. (2020) \\
\hline Research & $\begin{array}{l}\text { Isolation and } \\
\text { characterization of } \\
\text { Bacillus sp. Aerobic } \\
\text { denitrifying (strain YX-6) }\end{array}$ & $\begin{array}{l}\text { The results indicated that the YX-6 strain could degrade } \\
\text { nitrogen nitrite from } 10 \mathrm{mg} \mathrm{L}^{-1} \text { to zero in } 14 \text { hours. The rate of } \\
\text { nitrite-N degradation was approximately } 100 \% \text { at the } \\
\text { concentration of dissolved oxygen (DO) of } 5.2-5.8 \mathrm{mg} \mathrm{L}^{-1} \text {. } \\
\text { The aerobic denitrification of the YX-6 strain was greater than } \\
\text { the positive controls under different reaction conditions. }\end{array}$ & Song et al. (2011) \\
\hline
\end{tabular}

\section{Continue...}




\begin{tabular}{|c|c|c|c|}
\hline \multicolumn{4}{|c|}{ Continued... } \\
\hline Review & $\begin{array}{l}\text { Anammox (Anaerobic } \\
\text { ammonium oxidation) }\end{array}$ & $\begin{array}{l}\text { Bibliographic review that presents works published in the last } \\
15 \text { years on studies of the Anammox process, addressing its } \\
\text { metabolic route, the microorganisms involved and the process } \\
\text { control parameters, in addition to studies developed in Brazil } \\
\text { and possible applications. }\end{array}$ & Scheeren et al. (2011) \\
\hline Review & Biological filters & $\begin{array}{l}\text { This paper discusses the implications of the change in the use } \\
\text { of water recirculation systems in freshwater and marine } \\
\text { aquaculture and suggests that for freshwater aquaculture the } \\
\text { emphasis should be placed on cost competitiveness and } \\
\text { intensification of lagoons with RAS biofiltration. In marine } \\
\text { systems, the authors suggest the increase in demand for } \\
\text { oligotrophic and ultra-oligotrophic systems, mainly in nursery } \\
\text { systems. }\end{array}$ & Gutierrez-Wing and Malone (2006) \\
\hline Research & Polymer hydrogels & $\begin{array}{l}\text { The experiments carried out with polymer hydrogels showed } \\
\text { efficient removal of nutrients from aquaculture wastewater. } \\
\text { The removal of } \mathrm{PO}_{4}-\mathrm{P} \text { was } 98 \%, \mathrm{NO}_{3}-\mathrm{N} \text { was } 50 \% \text { and } \mathrm{NO}_{2}-\mathrm{N} \\
\text { was } 85 \% \text {, in a period of } 3 \text { hours of reaction. The results } \\
\text { demonstrate that hydrogels are suitable materials for } \\
\text { aquaculture wastewater treatment. }\end{array}$ & Kioussis et al. (2000) \\
\hline Research & $\begin{array}{l}\text { Ammonia removal with } \\
\text { nitrifying bacteria } \\
\text { immobilized on clay } \\
\text { pallets }\end{array}$ & $\begin{array}{l}\text { The results showed that enriched cultures immobilized on clay } \\
\text { pallets for } 6 \text { hours achieved a removal rate of } 3 \text { mg of TAN L- } \\
1 \text { day }^{-1} \text { during the log removal phase. The immobilized pallets } \\
\text { of } 30 \text { and } 72 \text { hours removed TAN from the culture medium } \\
\text { immediately, showing a removal rate of } 4 \mathrm{mg} \mathrm{L}^{-1} \text { day }^{-1} \text {. } \\
\text { Cultures immobilized for } 30 \text { hours were used to remove TAN } \\
\text { in situ with a density of } 1 \text { pallet/ } 100 \mathrm{~mL} \text {, obtaining removal } \\
\text { rates of } 4.2-6.7 \mathrm{mg}^{-} \text {TAN L } \mathrm{L}^{-1} \text { day }^{-1} \text {. }\end{array}$ & Shan and Obbard (2001) \\
\hline Review & $\begin{array}{l}\text { Electrochemical } \\
\text { technology; Reverse } \\
\text { osmosis; Adsorption; } \\
\text { Wetlands }\end{array}$ & $\begin{array}{l}\text { This article presents a detailed review of physicochemical and } \\
\text { biological techniques used to remove TAN, nitrate and } \\
\text { organic matter. Compares the electrochemical and } \\
\text { bioelectrochemical methods used to remove TAN, nitrate and } \\
\text { organic matter. }\end{array}$ & Mook et al. (2012) \\
\hline
\end{tabular}

Continue... 


\section{Continued...}

Sequencing batch reacto

Research for biological treatments

for low salinity effluents

Internal fibrous biofilter

for intermittent

Research nitrification and

denitrification treatments

Use of Bacillus to

Review maintain water quality in aquaculture

Systems combining aquaculture and plants

Granular expandable biofilters (EGBs);

Wetlands

Biological denitrification using Alcaligenesfaecalis strain in a continuous bioreactor
The results obtained showed that after the aerobic operation of

the reactors, the ammonia concentration dropped from $101 \mathrm{mg}$

$\mathrm{L}^{-1}$ to 0 on day 3 . Nitrate levels increased in the reactor from

33 to $88 \mathrm{mg} \mathrm{L}^{-1}$ on day 3 , reaching 0 on the day 8 when being operated under anoxic conditions. In aerobic activity, the nitrite concentration increased from 260 to $371 \mathrm{mg} \mathrm{L}^{-1}$ and during the anoxic phase, and there was a reduction of nitrite to

$3 \mathrm{mg} \mathrm{L}^{-1}$ on day 8 . With respect to carbon, there was a reduction from 1201 to $32 \mathrm{mg} \mathrm{L}^{-1}$.

Pre-acclimated biofilter, with an initial nitrification rate of

$17.1 \pm 12.4 \mathrm{mg}$ of TAN m $\mathrm{m}^{-2} \mathrm{~d}^{-1}$, was applied in a shrimp tank.

The biofilter's aerobic nitrification activity was sufficient to control ammonia and nitrite levels below $0.2 \mathrm{mg}-\mathrm{N} \mathrm{L}^{-1}$ with nitrate accumulation of up to $50 \mathrm{mg}-\mathrm{N} \mathrm{L}^{-1}$. The nitrate was removed after harvesting with the same biofilter with anoxic denitrification and addition of methanol with a ratio of $5: 1$.

This review highlights the aquaculture activities that lead to pollution and the possible mechanisms used by Bacillus to improve water quality. They recommend that a series of optimal conditions is established to increase the efficiency of Bacillus in modulating water quality.

This review provides an overview of aquaculture systems developed in historical times that may still be valuable for the future, bringing current problems and innovative ideas, especially with regard to the integration of halophytic plants as a biofilter in saline aquaculture systems.

In this work, the viability of a continuous bioreactor was analyzed using the NR strain for simultaneous removal of nitrogen and organic matter (TOC) in a single aerated reactor, instead of batch culture. The results showed removal of 66.7-

Satanwat et al. (2020) $78.3 \% \mathrm{NH}_{4}{ }^{+}-\mathrm{N}$ and $85.8-92.2 \%$ TOC.

\section{Continue...}


Continued...

\begin{tabular}{|c|c|c|c|}
\hline Review & Microbial based systems & $\begin{array}{l}\text { This article presents a review of successful results in the use } \\
\text { of microbial-based systems that have been documented } \\
\text { around the world, as well as some aspects to be considered in } \\
\text { the process and which will still be experienced before a } \\
\text { system is implemented. New advances in the use of } \\
\text { microbial-based systems and recommendations are also } \\
\text { presented. }\end{array}$ & Martínez-Córdova et al. (2015) \\
\hline Research & $\begin{array}{l}\text { Biological nitrification } \\
\text { and denitrification by the } \\
\text { strain Pseudomonas sp. }\end{array}$ & $\begin{array}{l}\text { The results showed that the Pseudomonas strain showed an } \\
\text { efficient capacity for heterotrophic nitrification-aerobic } \\
\text { denitrification. The TAN ( } 10 \mathrm{mg} \mathrm{L}^{-1} \text { ) was completely } \\
\text { removed in } 12 \text { hours. The nitrogen mass balance indicated } \\
\text { that } 70.8 \% \text { of the initial TAN was converted to gaseous } \\
\text { nitrogen and } 28.1 \% \text { to intracellular nitrogen. The optimal } \\
\text { conditions for removal of TAN, nitrate and nitrite were } \mathrm{pH} 7 \\
\text { with } \mathrm{C} / \mathrm{N} \text { ratios of } 8,12 \text { and } 12 \text {, respectively. }\end{array}$ & Deng et al. (2021) \\
\hline Review & $\begin{array}{l}\text { Biological nitrification; } \\
\text { Treatment ponds; } \\
\text { Biological filters; Biofloc } \\
\text { technology; Periphyton } \\
\text { treatment }\end{array}$ & $\begin{array}{l}\text { This review covers techniques for nitrogen removal from } \\
\text { aquaculture wastewater such as rotating biological counters, } \\
\text { drip filters, fluidized sand biofilters and granule filters, as } \\
\text { well as biofloc technology and periphyton treatment, known } \\
\text { as a dual-purpose technique, since it allows to treat } \\
\text { aquaculture water and simultaneously produce fish feed. }\end{array}$ & Crab et al. (2007) \\
\hline Review & Drip filters & $\begin{array}{l}\text { This review addresses the main mechanisms and parameters } \\
\text { that affect the design and performance of drip filters in } \\
\text { aquaculture, relationships between nitrification rates and } \\
\text { parameters that can affect the process kinetics. The filter } \\
\text { design procedures are presented and one of them, a model that } \\
\text { describes the nitrification performance of piston flow drip } \\
\text { filters, is covered in more detail. }\end{array}$ & Eding et al. (2006) \\
\hline
\end{tabular}

Continue...

Rev. Ambient. Água vol. 16 n. 6, e2747 - Taubaté 2021 
Continued...

This study evaluated fluidized sand biofilters as a treatment option to remove $\mathrm{BOD}_{5}$, TAN, total phosphorus, suspended

Research Fluidized sand biofilters solids and total coliforms from aquaculture effluents. Two sand sizes $0.11 \mathrm{~mm}$ and $0.19 \mathrm{~mm}$ were used and two

Davidson et al. (2008) operating techniques were evaluated. Biofilters removed 66$82 \% \mathrm{BOD}_{5}, 86-88 \%$ TAN and $15-41 \%$ phosphorus.

This study presents a catalytic ozonation membrane system

for the treatment of aquaculture wastewater, using Ti-

Research Catalytic ozonation membrane filter $\mathrm{Mn} / \mathrm{TiO}_{2} / \mathrm{Al}_{2} \mathrm{O}_{3}$ and $\mathrm{TiO}^{2} / \mathrm{Al}_{2} \mathrm{O}_{3}$ membranes, with Ti$\mathrm{Mn} / \mathrm{TiO}_{2} / \mathrm{Al}_{2} \mathrm{O}_{3}$ obtaining better catalytic capacity. The results showed that the suspended solids, TAN, $\mathrm{NO}_{2}$ and COD were efficiently removed, obtaining a wastewater recovery rate of $95.8 \%$

The bacterial consortium was tested for 15 days in a tank with controlled conditions. The ammonia concentration in the tanks with the pool was $4.8 \pm 0.068 \mu \mathrm{mL}^{-1}$, while in the

Research Consortium of bacteria control tank (without bacteria) it was $7.29 \pm 0.292 \mu \mathrm{mL}^{-1}$. The nitrite increase $\left(6.9 \pm 0.59 \mu \mathrm{mL}^{-1}\right)$ and nitrate $(4.16 \pm 0.58$

$\left.\mu \mathrm{mL}^{-1}\right)$. The survival rate in the tanks was $97.2 \pm 0.58 \%$, while in the control tanks it was $55 \pm 0.25 \%$.

This article presents a review of the microalgae-based IMTA systems described so far in the literature and evaluates

Integrated Multi Trophic

Review Aquaculture based on microalgae microalgae culture methods that are applied in the treatment of aquaculture wastewater such as periphyton, cell immobilization and pools of microalgae-bacteria.

This review presents an overview of the removal of nutrients based on microalgae from aquaculture residues, challenges

Review Removal of nutrients using microalgae encountered in the development of an efficient treatment system, as well as factors that affect the growth of microalgae and the removal of nutrients. New cultivation strategies are presented to increase biomass production and nutrient removal.

Milhazes-Cunha and Otero (2016)

and the removal of nutrients. New cultivation strategies are
presented to increase biomass production and nutrient
removal.

\section{Continue...}




\begin{tabular}{|c|c|c|c|}
\hline \multicolumn{4}{|c|}{ Continued... } \\
\hline Review & Built wetlands & $\begin{array}{l}\text { The review presents the most recent studies on the use of } \\
\text { wetlands for the treatment of saline wastewater, as well as the } \\
\text { factors that influence the efficiency of wetlands in the } \\
\text { treatment process and how greater efficiency can be achieved } \\
\text { by screening for halophytes, application of halophilic } \\
\text { microorganisms and optimization of operating parameters. }\end{array}$ & Liang et al. (2017) \\
\hline Research & Halophyte filter beds & $\begin{array}{l}\text { In } 88 \text { days of commercial operation on a fish and shrimp } \\
\text { farm, Salicornia europaea plant biofilters removed } 98.2 \pm \\
2.2 \% \text { dissolved inorganic nitrogen, } 23-69 \% \text { dissolved organic } \\
\text { nitrogen and } 36-89 \% \text { inorganic phosphorus dissolved in } \\
\text { routine operations. }\end{array}$ & Webb et al. (2012) \\
\hline Review & $\begin{array}{l}\text { Biological removal of } \\
\text { nitrate by assimilation or } \\
\text { dissimilation; Autotrophic } \\
\text { and heterotrophic } \\
\text { denitrification; Anammox }\end{array}$ & $\begin{array}{l}\text { Biological nitrate removal pathways are presented, as well as } \\
\text { links between denitrifying organisms and carbon in } \\
\text { recirculation systems, applications of biological nitrate } \\
\text { removal in recirculation systems and, finally, the anammox } \\
\text { process is discussed as an alternative for removing ammonia } \\
\text { and nitrate. }\end{array}$ & van Rijn et al. (2006) \\
\hline Research & $\begin{array}{l}\text { Sequencing batch reactor } \\
\text { for biological treatments } \\
\text { of shrimp effluents }\end{array}$ & $\begin{array}{l}\text { The results showed that the initial TAN concentration } \\
\text { dropped from } 72 \text { to } 0 \mathrm{mg} \mathrm{L}^{-1} \text { on day } 4 \text { during the aerobic } \\
\text { mode of operation. The nitrite level increased from } 46 \mathrm{mg} \mathrm{L}^{-1} \\
\text { at the beginning of the experiment to } 198 \mathrm{mg} \mathrm{L}^{-1} \text { on day } 7 \text {, } \\
\text { decreasing to } 0 \text { on day } 15 \text {, when it was operated anoxic. } \\
\text { Nitrate increased in the aerobic period from } 32 \text { to } 162 \mathrm{mg} \mathrm{L}^{-1} \\
\text { on day } 8 \text { and, during the anoxic process, reached } 0 \mathrm{mg} \mathrm{L}^{-1} \text { on } \\
\text { day } 15 . \mathrm{SBR} \text { also removed } 82 \% \text { of organic carbon from the } \\
\text { system. }\end{array}$ & Boopathy (2009) \\
\hline
\end{tabular}




\section{REFERENCES}

ALVES, C. F.; BORTOLUCI, C. B. C.; OLIVEIRA, E. P.; PIZZO, M. M.; RODRIGUEZ, R. P. Remoção biológica de nitrogênio em águas residuárias: uma revisão dos processos convencionais aos processos modernos. Revista Ibero-Americana de Ciências Ambientais, v. 9, n. 3, p. 174-187, 2018. https://doi.org/10.6008/cbpc21796858.2018.003.0015

BANSAL, R. C.; GOYAL, M. Activated carbon adsorption. Boca Raton: CRC Press, 2005. https://doi.org/10.1201/9781420028812

BOOPATHY, R.; BONVILLAIN, C.; FONTENOT, Q.; KILGEN, M. Biological treatment of low-salinity shrimp aquaculture wastewater using sequencing batch reactor. International Biodeterioration and Biodegradation, v. 59, n. 1, p. 16-19, 2007. https://doi.org/10.1016/j.ibiod.2006.05.003

BOOPATHY, R. Biological treatment of shrimp production wastewater. Journal of Industrial

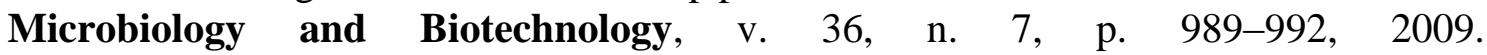
https://doi.org/10.1007/s10295-009-0577-0

CHATLA, D.; PADMAVATHI, P.; SRINU, G. Wastewater treatment techniques for sustainable aquaculture. In: GHOSH, S. K. (ed.). Waste Management as Economic Industry Towards Circular Economy. Singapore: Springer, 2020. p. 159-166.

CHÁVEZ-CROOKER, P.; OBREQUE-CONTRERAS, J. Bioremediation of aquaculture wastes. Current Opinion in Biotechnology, v. 21, n. 3, p. 313-317, 2010. https://doi.org/10.1016/j.copbio.2010.04.001

CHEN, S.; YU, J.; WANG, H.; YU, H.; QUAN, X. A pilot-scale coupling catalytic ozonation - membrane filtration system for recirculating aquaculture wastewater treatment. Desalination, v. 363, p. 37-43, 2014. https://doi.org/10.1016/j.desal.2014.09.006

CRAB, R.; AVNIMELECH, Y.; DEFOIRDT, T.; BOSSIER, P.; VERSTRAETE, W. Nitrogen removal techniques in aquaculture for a sustainable production. Aquaculture, v. 270, n. 1-4, p. 1-14, 2007. https://doi.org/10.1016/j.aquaculture.2007.05.006

DAVIDSON, J.; HELWIG, N.; SUMMERFELT, S. T. Fluidized sand biofilters used to remove ammonia, biochemical oxygen demand, total coliform bacteria, and suspended solids from an intensive aquaculture effluent. Aquacultural Engineering, v. 39, n. 1, p. 6-15, 2008. https://doi.org/10.1016/j.aquaeng.2008.04.002

DE MELO FILHO, M. E. S.; OWATARI, M. S.; MOURIÑO, J. L. P.; LAPA, K. R.; SOARES, H. M. Application of nitrification and denitrification processes in a direct water reuse system for pacific white shrimp farmed in biofloc system. Aquacultural Engineering, v. 88, 2020. https://doi.org/10.1016/j.aquaeng.2020.102043

DE MIRANDA, M. O. T. Cultivo de surubim pintado (Pseudoplatystoma corruscans) e híbrido ( $\boldsymbol{P}$. reticulatum $\boldsymbol{X} \boldsymbol{P}$. corruscans) em sistema de recirculação de água. 2012. 91 f. Tese (Doutorado em Ciências Biológicas) - Universidade Federal de São Carlos, São Carlos, 2012. 
DENG, M.; ZHAO, X.; SENBATI, Y.; SONG, K.; HE, X. Nitrogen removal by heterotrophic nitrifying and aerobic denitrifying bacterium Pseudomonas sp. DM02: Removal performance, mechanism and immobilized application for real aquaculture wastewater $\begin{array}{lllll}\text { treatment. Bioresource } & \text { Technology, } & \text { v. } & 322, & \end{array}$ https://doi.org/10.1016/j.biortech.2020.124555

EDING, E. H.; KAMSTRA, A.; VERRETH, J. A. J.; HUISMAN, E. A.; KLAPWIJK, A. Design and operation of nitrifying trickling filters in recirculating aquaculture: A review. Aquacultural Engineering, v. 34, n. 3, p. 234-260, 2006. https://doi.org/10.1016/j.aquaeng.2005.09.007

FAO. The State of world fisheries and Aquaculture. Rome, 2020.

FREDDI, L. A. Uso de reator de biofilme aerado em membrana no tratamento de efluente de sistema de recirculação aquícola. 2019. Dissertação (Mestrado em Saneamento) Universidade Estadual Paulista, Ilha Solteira, 2019.

GUTIERREZ-WING, M. T.; MALONE, R. F. Biological filters in aquaculture: Trends and research directions for freshwater and marine applications. Aquacultural Engineering, v. 34, n. 3, p. 163-171, 2006. https://doi.org/10.1016/j.aquaeng.2005.08.003

HLORDZI, V.; KUEBUTORNYE, F. K. A.; AFRIYIE, G.; ABARIKE, E. D.; LU, Y.; CHI, S.; ANOKYEWAA, M. A. The use of Bacillus species in maintenance of water quality in aquaculture: A review. Aquaculture Reports, 18, 2020. https://doi.org/10.1016/j.aqrep.2020.100503

HUANG, F.; PAN, L.; HE, Z.; ZHANG, M.; ZHANG, M. Culturable heterotrophic nitrification-aerobic denitrification bacterial consortia with cooperative interactions for removing ammonia and nitrite nitrogen in mariculture effluents. Aquaculture, v. 523, 2020. https://doi.org/10.1016/j.aquaculture.2020.735211

JOHN, E. M.; KRISHNAPRIYA, K.; SANKAR, T. V. Treatment of ammonia and nitrite in aquaculture wastewater by an assembled bacterial consortium. Aquaculture, v. 526, 2020. https://doi.org/10.1016/j.aquaculture.2020.735390

KIOUSSIS, D. R.; WHEATON, F. W.; KOFINAS, P. Reactive nitrogen and phosphorus removal from aquaculture wastewater effluents using polymer hydrogels. Aquacultural Engineering, v. 23, n. 4, p. 315-332, 2000. https://doi.org/10.1016/S01448609(00)00058-3

KRUMMENAUER, D.; SAMOCHA, T.; POERSCH, L.; LARA, G.; WASIELESKY, W. The reuse of water on the culture of pacific white shrimp, Litopenaeus vannamei, in BFT system. Journal of the World Aquaculture Society, v. 45, n. 1, p. 3-14, 2014. https://doi.org/10.1111/jwas.12093

KUBITZA, F. Sistemas de Recirculação: Sistemas fechados com tratamento e reuso da água. Panorama da Aquicultura, v. 16, n. 95, p. 15-22, 2006.

LIANG, Y.; ZHU, H.; BAÑUELOS, G.; YAN, B.; ZHOU, Q.; YU, X. et al. Constructed wetlands for saline wastewater treatment: A review. Ecological Engineering, v. 98, p. 275-285, 2017. https://doi.org/10.1016/j.ecoleng.2016.11.005 
MANGARENGI, N. A. P.; SELINTUNG, M.; ZUBAIR, A.; AHMAD, F. Evaluation of the effectiveness of wastewater treatment plant for super-intensive shrimp farms (A case study on Punaga Village, Takalar). IOP Conference Series: Earth and Environmental Science, v. 419, n. 1, 2020. https://doi.org/10.1088/1755-1315/419/1/012162

MANJU, N. J.; DEEPESH, V.; ACHUTHAN, C.; ROSAMMA, P.; SINGH, I. S. B. Immobilization of nitrifying bacterial consortia on wood particles for bioaugmenting nitrification in shrimp culture systems. Aquaculture, v. 294, n. 1-2, p. 65-75, 2009. https://doi.org/10.1016/j.aquaculture.2009.05.008

MARONEZE, M. M.; ZEPKA, L. Q.; VIEIRA, J. G.; QUEIROZ, M. I.; JACOB-LOPES, E. A tecnologia de remoção de fósforo: Gerenciamento do elemento em resíduos industriais. Revista Ambiente \& Água, v. 9, n. 3, p. 445-458, 2014. https://doi.org/10.4136/ambiagua.1403

MARTÍNEZ-CÓRDOVA， L. R.; EMERENCIANO， M.; MIRANDA-BAEZA， A.; MARTÍNEZ-PORCHAS, M. Microbial-based systems for aquaculture of fish and shrimp: An updated review. Reviews in Aquaculture, v. 7, n. 2, p. 131-148, 2015. https://doi.org/10.1111/raq.12058

MILHAZES-CUNHA, H.; OTERO, A. Valorisation of aquaculture effluents with microalgae: The Integrated Multi-Trophic Aquaculture concept. Algal Research, v. 24, p. 416-424, 2016. https://doi.org/10.1016/j.algal.2016.12.011

MOOK, W. T.; CHAKRABARTI, M. H.; AROUA, M. K.; KHAN, G. M. A.; ALI, B. S.; ISLAM, M. S. et al. Removal of total ammonia nitrogen (TAN), nitrate and total organic carbon (TOC) from aquaculture wastewater using electrochemical technology: A review. Desalination, v. 285, p. 1-13, 2012. https://doi.org/10.1016/j.desal.2011.09.029

NI, S.-Q.; AHMAD, H. A.; AHMAD, S. Immobilization of anaerobic ammonium oxidation bacteria for nitrogen-rich wastewater treatment. In: SHAH, P.; RODRIGUEZ-COUTO, S.; ŞENGÖR, S. S. Emerging Technologies in Environmental Bioremediation. Elsevier, 2020. https://doi.org/10.1016/b978-0-12-819860-5.00001-8

NIE, X.; MUBASHAR, M.; ZHANG, S.; QIN, Y.; ZHANG, X. Current Progress, Challenges and Perspectives in Microalgae-Based Nutrient Removal for Aquaculture Waste: A Comprehensive Review. Journal of Cleaner Production, v. 277, 2020. https://doi.org/10.1016/j.jclepro.2020.124209

PIRES, H. A. Tratamento de efluente da industrialização de pescado com sistema de ultrafiltração. 2017. Dissertação (Mestrado em ciência Animal) - Universidade Estadual Paulista (Unesp), Faculdade de Medicina Veterinária, Araçatuba, 2017.

SATANWAT, P.; TRAN, T. P.; HIRAKATA, Y.; WATARI, T.; HATAMOTO, M.; YAMAGUCHI, T. et al. Use of an internal fibrous biofilter for intermittent nitrification and denitrification treatments in a zero-discharge shrimp culture tank. Aquacultural Engineering, v. 88, 2020. https://doi.org/10.1016/j.aquaeng.2019.102041

SAUER, T. Tratamento de Efluentes de Curtume através do Processo Combinado de Degradação Fotocatalítica Seguida por Adsorção em Carvão Ativado. 2006. 249p. Tese (Doutorado em Engenharia Química) - Universidade Federal de Santa Catarina, Florianópolis, 2006. 
SCHEEREN, M. B.; KUNZ, A.; STEINMETZ, R. L. R.; DRESSLER, V. L. O processo ANAMMOX como alternativa para tratamento de águas residuárias, contendo alta concentração de nitrogênio. Revista Brasileira de Engenharia Agrícola e Ambiental, v. 15, n. 12, p. 1289-1297, 2011. https://doi.org/10.1590/s1415-43662011001200011

SHAN, H.; OBBARD, J. P. Ammonia removal from prawn aquaculture water using immobilized nitrifying bacteria. Applied Microbiology and Biotechnology, v. 57, n. 56, p. 791-798, 2001. https://doi.org/10.1007/s00253-001-0835-1

SINGH, M.; SRIVASTAVA, R. K. Sequencing batch reactor technology for biological wastewater treatment: a review. Asia-pacific journal of chemical engineering, v. 6, n. 1, 2011. https://doi.org/10.1002/apj.490

SONG, Z. F.; AN, J.; FU, G. H.; YANG, X. L. Isolation and characterization of an aerobic denitrifying Bacillus sp. YX-6 from shrimp culture ponds. Aquaculture, v. 319, n. 1-2, p. 188-193, 2011. https://doi.org/10.1016/j.aquaculture.2011.06.018

SOUZA, J. E. S. de; ARAÚJO, B. A.; SARMENTO, K. K. F.; REBOUÇAS, L. D.; MEDEIROS, K. M. de; LIMA, C. A. P. de. Membranas de nanocompósitos poliméricos com óxido de zinco para o tratamento de efluentes: Revisão de literatura. Research, Society and Development, v. 10, n. 8, 2021. https://doi.org/10.33448/rsd-v10i8.17402

STEICKE, C.; JEGATHEESAN, V.; ZENG, C. Mechanical mode floating medium filters for recirculating systems in aquaculture for higher solids retention and lower freshwater usage. Bioresource Technology, v. 98, p. 3375-3383, 2007. https://doi.org/10.1016/j.biortech.2006.10.042

TURCIOS, A. E.; PAPENBROCK, J. Sustainable treatment of aquaculture effluents-What can we learn from the past for the future? Sustainability, v. 6, n. 2, p. 836-856, 2014. https://doi.org/10.3390/su6020836

VAN RIJN, J.; TAL, Y.; SCHREIER, H. J. Denitrification in recirculating systems: Theory and applications. Aquacultural Engineering, v. 34, n. 3, p. 364-376, 2006. https://doi.org/10.1016/j.aquaeng.2005.04.004

WEBB, J. M.; QUINTA, R.; PAPADIMITRIOU, S.; NORMAN, L.; RIGBY, M.; THOMAS, D. N. et al. Halophyte filter beds for treatment of saline wastewater from aquaculture. Water Research, v. 46, n. 16, 2012 https://doi.org/10.1016/j.watres.2012.06.034

ZHAO, B.; TIAN, M.; AN, Q.; YE, J.; GUO, J. S. Characteristics of a heterotrophic nitrogen removal bacterium and its potential application on treatment of ammonium-rich

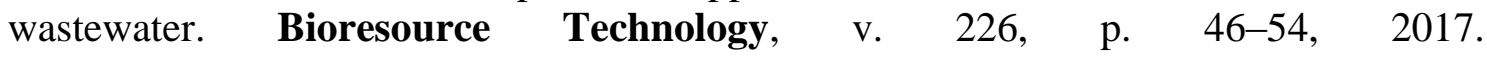
https://doi.org/10.1016/j.biortech.2016.11.120

ZHAO, J.; LI, Y.; CHEN, X.; LI, Y. Effects of carbon sources on sludge performance and microbial community for 4-chlorophenol wastewater treatment in sequencing batch

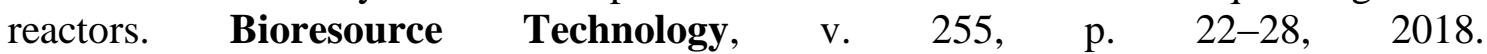
https://doi.org/10.1016/j.biortech.2018.01.106

ZOPPAS, F. M.; BERNARDES, A. M.; MENEGUZZI, Á. Parâmetros operacionais na remoção biológica de nitrogênio de águas por nitrificação e desnitrificação simultânea. Engenharia Sanitaria e Ambiental, v. 21, n. 1, p. 29-42, 2016. https://doi.org/10.1590/S1413-41520201600100134682 


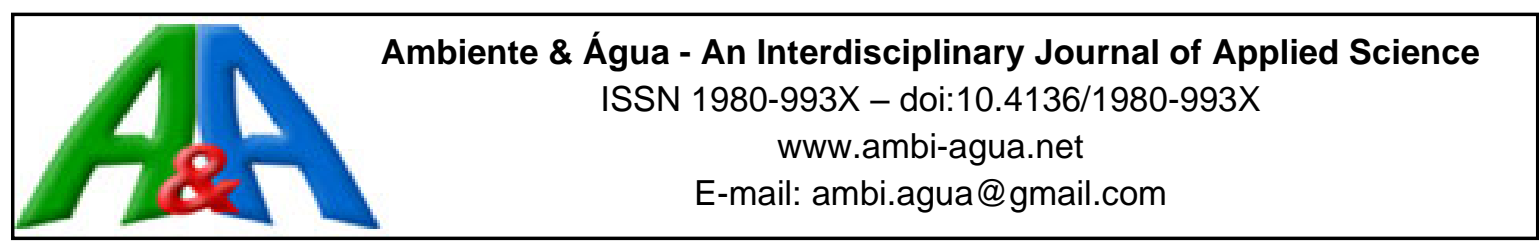

\title{
Interaction of precipitation with tree canopy increases nutrient input
}

\author{
ARTICLES doi:10.4136/ambi-agua.2761
}

Received: 20 Jun. 2021; Accepted: 04 Oct. 2021

\begin{abstract}
Gian Carlos Poleto ${ }^{1}$; ; Dione Richer Momolli ${ }^{1 *}$; Mauro Valdir Schumacher ${ }^{1}{ }^{(D)}$; Aline Aparecida Ludvichak ${ }^{1}$; Kristiana Fiorentin dos Santos ${ }^{2}$; Márcio Viera ${ }^{1}$; Clayton Alcarde Alvares ${ }^{3}$ iD; James Stahl ${ }^{4}$ id

${ }^{1}$ Universidade Federal de Santa Maria (UFSM), Avenida Roraima, n 1000, CEP: 97105-900, Santa Maria, RS, Brazil.E-mail: gianpoleto@gmail.com, mauro.schumacher@ufsm.br, aline_lud@yahoo.com.br, marcio.viera@ufsm.br

${ }^{2}$ Departamento de Engenharia Florestal. Universidade Regional de Blumenau (FURB), Rua São Paulo, n 3250, CEP: 89030-000, Blumenau, SC, Brazil. E-mail: kristianafiorentin@ gmail.com

${ }^{3}$ Suzano SA, Estrada Limeira, n 391, CEP: 13465-970, Limeira, SP, Brazil. E-mail: calcarde@ suzano.com.br ${ }^{4}$ Klabin S.A., Unidade de Monte Alegre, Avenida Brasil, n 26, CEP: 84275-000, Telêmaco Borba, PR, Brazil. E-mail: jstahl@klabin.com.br

*Corresponding author. E-mail: dionemomolli@gmail.com
\end{abstract}

\begin{abstract}
Given that atmospheric deposition is the first source of nutrient input into forest ecosystems, and that the precipitation partition serves as a nutritional source mainly when there is an interaction with the forest canopy, the objective of the present study was to quantify the nutrients input into rainfall, throughfall and stemflow in Eucalyptus urophylla stands with partial exclusion (E) and without exclusion (WE) of throughfall. The experiment was conducted in the northeast of the state of Paraná-Brazil, in the municipality of Telêmaco Borba. The partial precipitation exclusion system (E) is formed by a system of gutters that conduct $30 \%$ of throughfall out of the experiment. The nutrient input in rainfall was $55.7 \mathrm{~kg} \mathrm{ha}^{-1} \mathrm{yr}^{-1}$, while the sum of throughfall and stemflow was $64.1 \mathrm{~kg} \mathrm{ha}^{-1} \mathrm{yr}^{-1}$ in treatment (WE) and $39.8 \mathrm{~kg} \mathrm{ha}^{-1} \mathrm{yr}^{-1}$ in treatment (E). Interaction with the canopy of the trees enriched the rainfall with nutrients, mainly the elements potassium and chlorine, due to leaching of the vegetal tissues. The reduction of the water treatment system in partial exclusion of precipitation (E) reduced representative nutrient input. Although stemflow represents on average only $2.6 \%$ of the water volume, it is responsible for $6.7 \%$ of the amount of nutrients in relation to precipitation. Therefore, stemflow cannot be neglected in the balance of nutrient cycling. With a rotation of 7 years, the application of significant amounts of fertilizers can be avoided, considering the inputs of 449 and $277 \mathrm{~kg} \mathrm{ha}^{-1} \mathrm{year}^{-1}$.
\end{abstract}

Keywords: nutrient cycling, stemflow, throughfall.

\section{Interação da precipitação com o dossel florestal aumenta o aporte de nutrientes}

\section{RESUMO}

Sabendo que a deposição atmosférica é a primeira fonte de entrada de nutrientes nos ecossistemas florestais e que a partição de precipitação serve como fonte nutricional principalmente quando há interação com o dossel florestal, o objetivo do presente estudo foi 
quantificar o aporte de nutrientes na precipitação incidente, precipitação interna e escoamento pelo tronco em um povoamento de Eucalyptus urophylla com exclusão parcial (E) e sem exclusão parcial (WE) da precipitação interna. O experimento está localizado no nordeste do estado do Paraná-Brasil, no município de Telêmaco Borba. O sistema de exclusão parcial de precipitação (E) é formado por um sistema de calhas que conduzem $30 \%$ da precipitação interna para fora do experimento. $\mathrm{O}$ aporte de nutrientes pela precipitação incidente foi de $55.7 \mathrm{~kg} \mathrm{ha}^{-}$ ${ }_{1}$ ano $^{-1}$, enquanto que a soma dos mesmos na precipitação interna e escoamento pelo tronco foram de $39.8 \mathrm{~kg} \mathrm{ha}^{-1} \mathrm{ano}^{-1}$ no tratamento com exclusão (E) e de $64.1 \mathrm{~kg} \mathrm{ha}^{-1} \mathrm{ano}^{-1}$ no tratamento sem exclusão (WE). A interação com o dossel florestal enriquece com nutrientes especialmente com os elementos potássio e cloro devido a lixiviação dos tecidos vegetais. A redução do regime hídrico no tratamento com exclusão parcial da precipitação (E) reduziu de forma representativa a entrada de nutrientes. Embora o escoamento pelo tronco represente em média apenas $2.6 \%$ do volume de água, ele é responsável por $6.7 \%$ da quantidade de nutrientes em relação à precipitação. Portanto, o mesmo não pode ser negligenciado no balanço da ciclagem de nutrientes. Com uma rotação de 7 anos a aplicação de importantes quantidades de fertilizantes podem ser evitados considerando as entradas de 449 e $277 \mathrm{~kg} \mathrm{ha}^{-1} \mathrm{ano}^{-1}$.

Palavras-chave: ciclagem de nutrientes, escoamento pelo tronco, precipitação interna.

\section{INTRODUCTION}

The forestry sector has occupied a prominent position in the Brazilian economy. Planted forests occupy 9.0 million hectares of the country and the genus Eucalyptus represents $77 \%$ of this area. Even with the large area occupied, the industrial forest plantations cover about $0.92 \%$ of the Brazilian territory. Paper and cellulose commodities occupy the second place in the list of products most exported by Brazil (IBÁ, 2020).

Extensive areas occupied by forest plantations are able to modify the hydrological balance (Ferraz et al. 2019). The partition of the rainfall in the area covered by vegetation is very dynamic. During precipitation, a portion of the water is intercepted by the canopy and immediately evaporated into the atmosphere (Llorens and Domingo, 2007). Part of the precipitation crosses the canopy and drips into the stand; this is called "throughfall" (Navar, 2011). A portion of the throughfall flows from the leaves to the branches and trunk, reaching the base of the tree; this portion is called "stemflow" (Zhang et al., 2016; Johnson and Lehmann, 2006). The knowledge of the partition of precipitation is important in studies of modeling the water balance of a watershed; however, many studies have considered a generic value for the index of canopy interception (Chaffe et al., 2010).

Many studies show the importance of the partition of precipitation in the biogeochemical cycle of nutrients (Staelens et al., 2006; Fan et al., 2015). Some studies also point out that the productivity and stability of a forest ecosystem is determined by the cycling of nutrients (Likens 2013). According to Viera and Schumacher (2010), part of the input of nutrients into an ecosystem occurs through precipitation that carries dust particles from the atmosphere to the ground. In addition, when interacting with the canopy of the trees, precipitation leaches the different tissues of the plant, increasing the nutritional contribution (Schrumpf et al., 2006; Bhat et al., 2011; Levia et al., 2011). Thus, precipitation is responsible for providing information regarding environmental quality (Zhou et al., 2019). In addition, soils from areas of low natural fertility, the entry of nutrients by precipitation may be the only nutritional source (Dawoe et al., 2018; Lu et al., 2017).

The chemical composition of throughfall and stemflow is influenced by the interaction of water with the forest canopy, distance from the sea and anthropogenic activities (Andre et al., 2008; Navar et al., 2009; Tiwari et al., 2016). In general, these pathways provide an important 
nutritional source for tree roots, especially with cation enrichment (Zhang et al., 2013; Su et $a l ., 2019)$. Although the stemflow represents a small portion of the volume of water that reaches the forest soil, this solution is responsible for accelerating the redistribution of nutrients and changing the physico-chemical properties in the root region (Swaffer et al., 2014; Momolli et al. 2019b)

Climate change has caused great variation in the rainfall regime (Allan and Soden, 2008), in addition, the water regime in southern Brazil is determined by atmospheric-oceanic phenomena. When equatorial waters in the Pacific Ocean cool, the phenomenon of "La Niña" occurs, which is responsible for the significant decrease in rainfall in this region. As a consequence, there is a loss of productivity of several crops, including those of Eucalyptus plantations. This study evaluates nutrient input into rainfall, throughfall and stemflow in a Eucalyptus stand with and without partial exclusion of throughfall.

\section{MATERIALS AND METHODS}

\subsection{Characterization of the experimental area}

The experimental area is located in the northeast region of the state of Paraná, in the municipality of Telêmaco Borba, under the geographic coordinates $24^{\circ} 13^{\prime} 41.0^{\prime \prime} \mathrm{S}$ and $50^{\circ} 31^{\prime} 40.0$ " W. The climate classification is Cfb (temperate climate), with an average annual temperature of $18.8^{\circ} \mathrm{C}$ and an average annual precipitation of $1646 \mathrm{~mm}$, according to the Köppen classification (Alvares et al., 2014). According to Flores et al. (2016) the species $E$. urophylla is classified as having low climatic aptitude for the study region.

Figure 1 shows meteorological data for the period from July 2017 to June 2018, obtained from the meteorological station located at the company Klabin SA in Telêmaco Borba - PR Brazil at $880 \mathrm{~m}$ altitude, $24^{\circ} 12^{\prime} 40.6^{\prime \prime} \mathrm{S}$ and 50 33'29.2" $\mathrm{W}$. The distance between the experimental area and the weather station is approximately $3.4 \mathrm{~km}$ in a straight line.

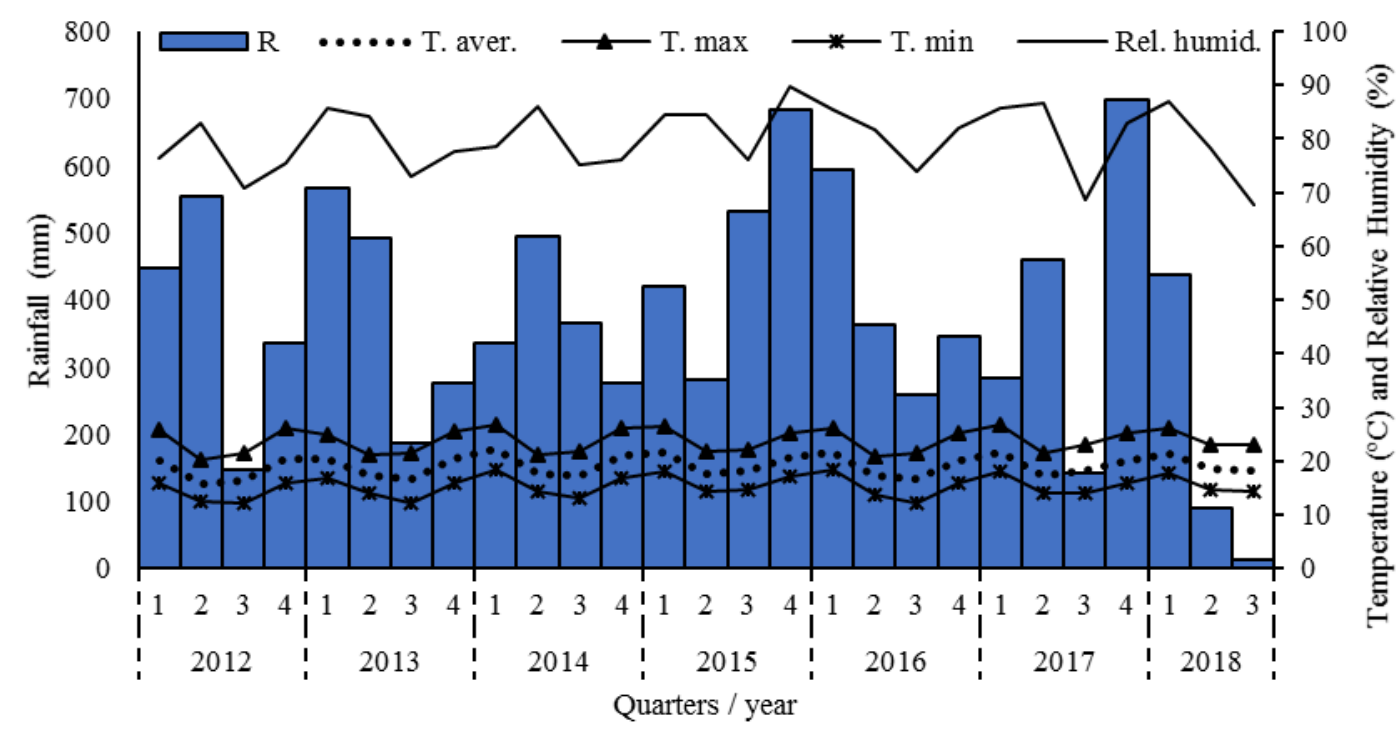

Figure 1. Weather data for the municipality of Telêmaco Borba, PR during the study period.

In March 2017, dendrometric characterization was performed, measuring the height and diameter at breast height $(\mathrm{DBH})$ of all trees. The mean $\mathrm{DBH}$ and the total height in the Exclusion (E) treatment were $16.8 \mathrm{~cm}$ and $28.6 \mathrm{~m}$, respectively. For the Without Exclusion (WE) treatment, the mean DBH was $17.3 \mathrm{~cm}$ and the total height $28.3 \mathrm{~m}$. The volume per hectare in the E and WE treatment was 346 and $365 \mathrm{~m}^{3} \mathrm{ha}^{-1}$, respectively. The leaf area index was 2.95 and 2.82 for treating exclusion (E) and without exclusion (WE), respectively. 


\subsection{Experimental design}

The study belongs to the TECHS project (Tolerance of Eucalyptus Clones to Hydric, Thermal and Biotic Stresses). The experiment was carried out in a completely randomized design, with $720 \mathrm{~m}^{2}$ plots of eight lines with ten plants each in spacing of $3 \mathrm{~m} \times 3 \mathrm{~m}(1,111$ trees ha-1). For the hybrid E. urophylla x E. sp. two treatments of the water regime were defined: one receiving $100 \%$ of the throughfall (WE) and the other receiving only $70 \%$ of the throughfall (E). For the treatment (E) that received $70 \%$ of the precipitation, a system of partial exclusion of the throughfall was used with plastic gutters that prevented the precipitation reaching the ground. A schematic representation of the precipitation exclusion treatment (E) can be seen in Figure 2. This technique is based on the coverage between the planting lines covering $216 \mathrm{~m}^{2}$ of the area of each treatment, being the equivalent to $30 \%$ of the plot area (Binkley et al., 2017).

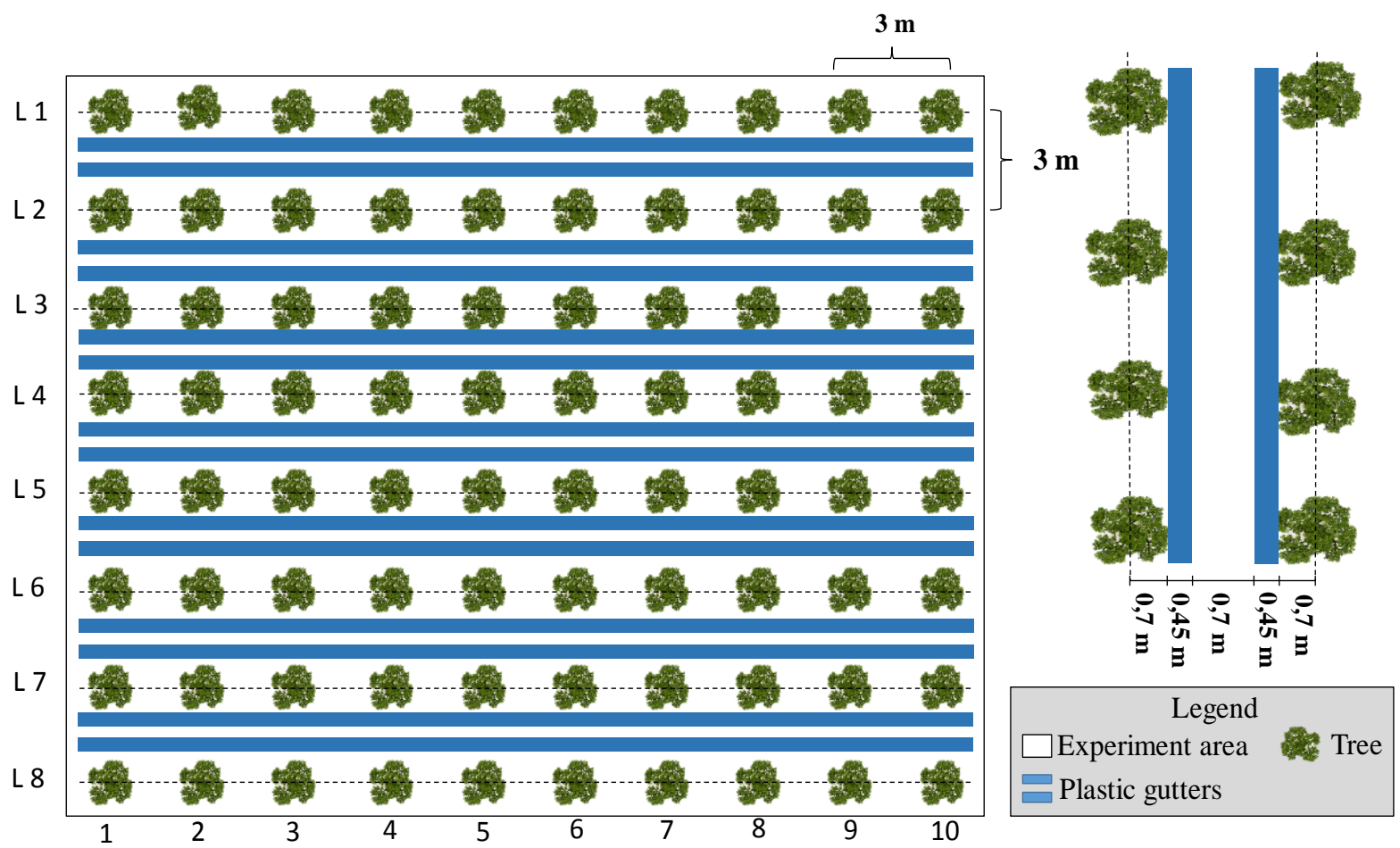

Figure 2. Representative scheme of the partial precipitation exclusion treatment (E), with dimensions and spacing.

The monitoring of the partition of precipitation under the two rainfall regimes occurred from July 2017 to June 2018. Sampling was started when the stand was 66 months old. For the (E) treatment, a partial exclusion system of throughfall was used, installed when the stand was one year old.

\subsection{Measurement of rainfall, throughfall and stemflow}

To quantify the rainfall $(\mathrm{R})$, three collectors with a $20 \mathrm{~cm}$ catchment diameter were installed in an area adjacent to the eucalyptus stand at a height of $1.5 \mathrm{~m}$ above ground level. Straps with steel wires were placed in order to prevent birds from using the collectors as perches.

For the evaluation of throughfall (Tf), nine collectors per treatment were installed, with a collection diameter of $20 \mathrm{~cm}$ and height of $1 \mathrm{~m}$ from ground level, systematically distributed along the line, between the lines and diagonally between four trees. Collections were started at 66 months of age. 
The stemflow quantification (Sf) occurred with the installation of nine sets formed by a plastic hose with a diameter of one inch and a reservoir for water storage. The hose was cut longitudinally and then it was installed in a spiral shape on the tree trunk. This configuration allowed the water to drain through the trunk and be stored in the reservoir.

Bi-weekly, the values of rainfall (R), throughfall (Tf) and stemflow (Sf) were measured. To obtain the values of precipitation and throughfall in millimeters, the following Equation 1 was used:

$R=V / a$

Where:

$\mathrm{R}=$ rainfall (mm);

$\mathrm{V}=$ volume collected $(\mathrm{L})$;

$\mathrm{a}=$ collector area $\left(\mathrm{m}^{2}\right)$.

The values of stemflow were obtained using the following Equation 2, used by Preuhsler et al. (2006):

$S f=\left(\frac{V}{g}\right) *\left(\frac{G}{A}\right)$

Where:

$\mathrm{Sf}=$ stemflow $(\mathrm{mm})$;

$\mathrm{V}=$ volume collected $(\mathrm{L})$;

$\mathrm{g}=$ basal area of the tree $\left(\mathrm{m}^{2}\right)$;

$\mathrm{G}=$ basal area of the plot $\left(\mathrm{m}^{2}\right)$;

$A=$ plot area $\left(m^{2}\right)$.

For the canopy interception calculation, the Equation 3 was used:

$I=\frac{R-(T f+S f)}{R} * 100$

Where:

$\mathrm{I}=$ canopy interception $(\%)$;

$\mathrm{R}=$ rainfall (mm);

$\mathrm{Tf}=$ throughfall $(\mathrm{mm})$;

$\mathrm{Sf}=$ stemflow $(\mathrm{mm})$.

The rainfall and throughfall collectors were composed of plastic bottles with a capacity of 2 liters, and the collections were carried out every 15 days. The throughfall collectors were arranged on the line, between the lines and diagonally between four trees. The stemflow samples were also collected for chemical analysis every 15 days.

\subsection{Statistics and Data Analysis}

The rainfall, throughfall and stemflow samples were sent to the Forest Ecology Laboratory where the $\mathrm{pH}$ was determined. For this variable, the electrode (Methohm $827 \mathrm{pH}$ LAB) was used, and filtered with a $0.45 \mu \mathrm{m}$ pore filter. According to the methodology proposed by the 
American Public Health Association (APHA et al., 1998), $\mathrm{NO}_{2}^{-}, \mathrm{NO}_{3}^{-}, \mathrm{PO}_{4}{ }^{3-}, \mathrm{SO}_{4}^{-}, \mathrm{Cl}^{-}, \mathrm{K}^{+}, \mathrm{Ca}^{2+}$ and $\mathrm{Mg}^{2+}$ ions were analyzed, with a pre-treatment with simple filtration followed by ion chromatography. The amount of nutrient input is given by multiplying the concentrations of ions ( $\left.\mathrm{mg} \mathrm{L}^{-1}\right)$ by the volume (liters).

The Tukey average test was performed at $5 \%$ probability of error for ion concentrations between precipitation, throughfall and stemflow. In order to verify the dilution effect, Pearson's correlations were applied between the volumes of rainfall partitions and the concentrations of ions. All statistical analyses were performed using SPSS 18.0 (SPSS Inc., Chicago, IL, USA).

\section{RESULTS AND DISCUSSION}

\subsection{Rainfall partitioning}

During the monitored period, the quantified precipitation was $1627 \mathrm{~mm}$. The month of December 2017 had the highest volume of R $371 \mathrm{~mm}$, while the months of July 2017 and April 2018 registered the lowest volumes $(0.00$ and $21 \mathrm{~mm})$ (Figure 3$)$.

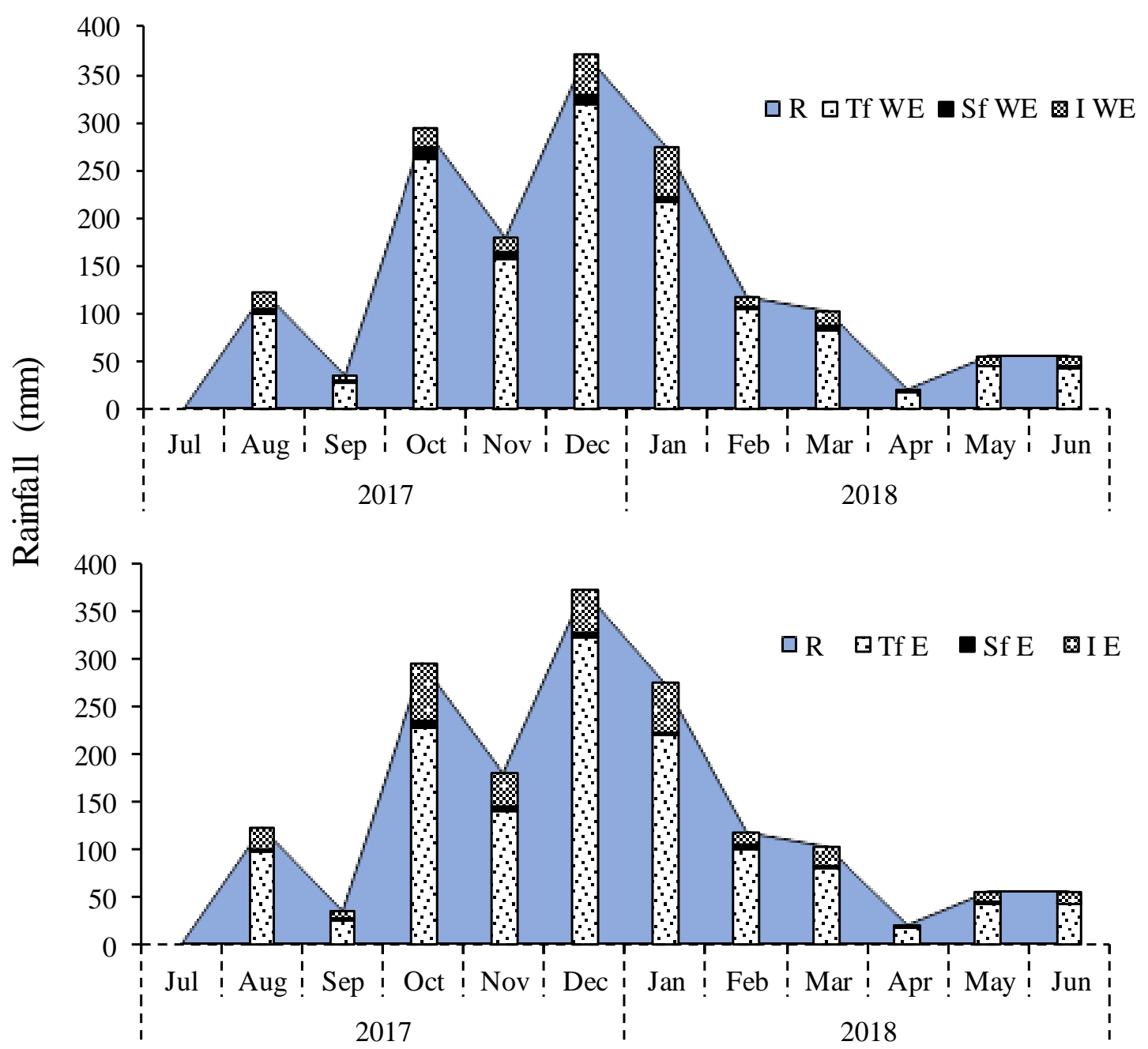

Figure 3. Temporal variation of the partition of pluviometric precipitation.

Regarding throughfall, the WE treatment showed $1379 \mathrm{~mm}$, equivalent to $84.8 \%$ of the precipitation. In contrast, the $\mathrm{E}$ treatment showed a lower value $(1311 \mathrm{~mm})$, corresponding to $80.6 \%$ of the precipitation. The volume collected for the Sf WE treatment was $48.40 \mathrm{~mm}$, representing $2.9 \%$ of the rainfall. For the Sf E treatment, $37 \mathrm{~mm}$ was accumulated, corresponding to $2.3 \%$ of the rainfall. In the canopy interception, the lowest observed value was 
$200 \mathrm{~mm}(12.3 \%)$ for WE treatment, while in treatment $\mathrm{E}$ the value was $280 \mathrm{~mm}$ (17.2\%) (Poleto et al., 2021).

\subsection{Chemical composition of rainfall, throughfall and stemflow}

In the evaluated period (Figure 3), the average $\mathrm{pH}$ value of rainfall was 6.17. The throughfall for the E and WE treatment of the throughfall was 5.94 and 5.96, respectively. Stemflow provided an average of 4.92 and 4.55 for the E and WE treatment of throughfall (Figure 4).

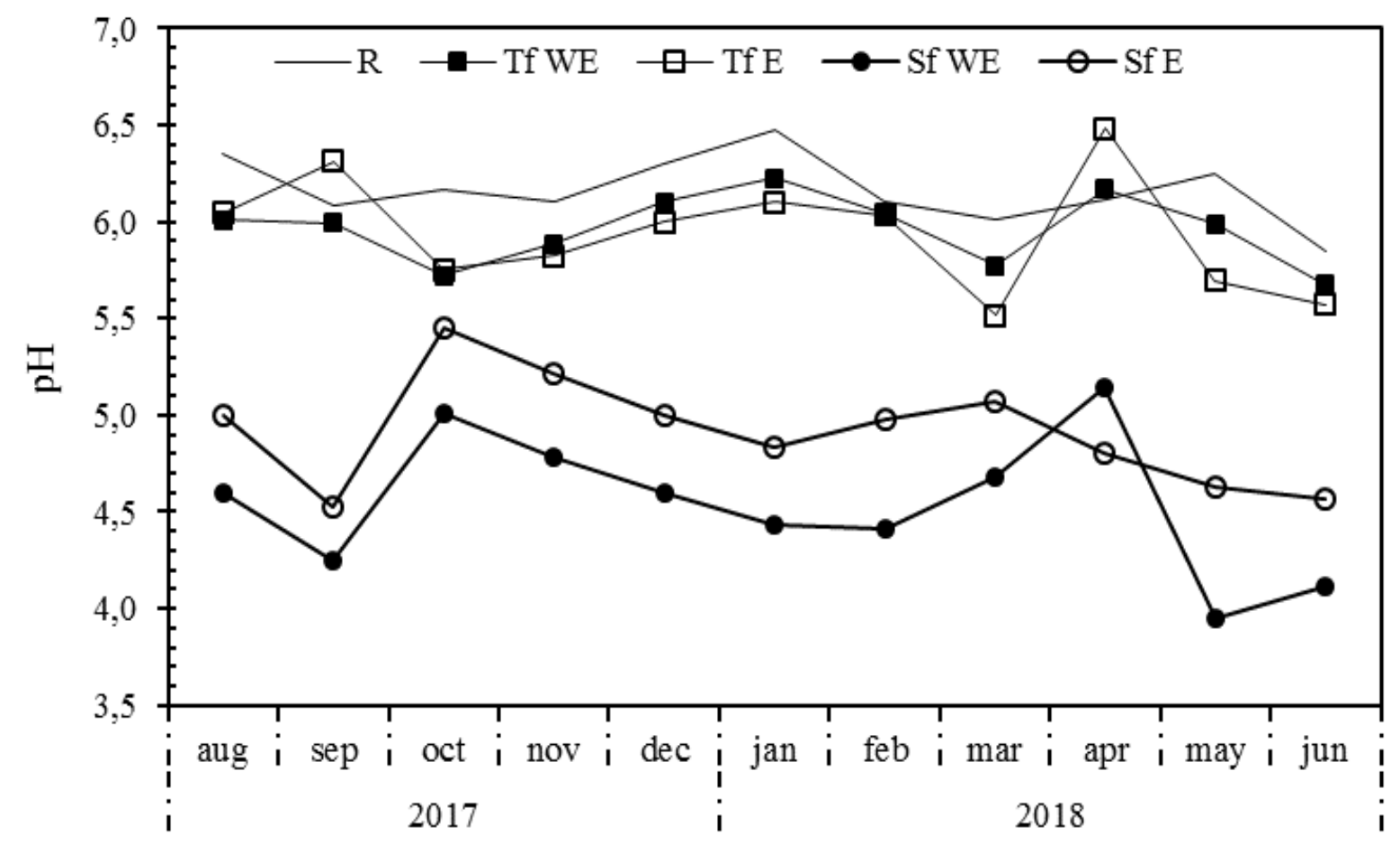

Figure 4. Average $\mathrm{pH}$ values of rainfall, throughfall and stemflow in the hybrid Eucalyptus urophylla $\mathrm{x}$ E. sp.

Momolli (2019b) found mean $\mathrm{pH}$ values of 4.57 for rainfall, 4.64 for throughfall and 5.54 for stemflow evaluation in a 7 to 8-year-old Eucalyptus dunnii stand in Alegrete, RS. Assessing the same species, from 4 to 5 years old, Dick et al. (2018) also found an increase in $\mathrm{pH}$ as precipitation interacts with the canopy. The $\mathrm{pH}$ was 4.3 in rainfall, 5.0 in the throughfall and 5.3 in the stemflow, respectively.

The ion concentration is variable as it interacts with the forest canopy. The $\mathrm{SO}_{4}{ }^{2-}$ and $\mathrm{Ca}^{2+}$ ions showed higher levels of rainfall, differing statistically from other rainfall partitions. Inverse behavior was observed with respect to $\mathrm{Cl}^{-}, \mathrm{Na}^{+}, \mathrm{N}_{-} \mathrm{NH}_{4}^{+}, \mathrm{K}^{+}, \mathrm{Mg}^{2+}$ ions that registered the greatest increases, especially in Stemflow and Throughfall. The ions $\mathrm{N}_{-} \mathrm{NO}_{2}{ }^{-}$and $\mathrm{P}-\mathrm{PO}_{4}{ }^{3-}$ showed no statistically significant difference. The mean test of the ions analyzed for each partition of the precipitation in the two water regimes can be verified in Table 1.

It is observed that the concentration of nutrients is influenced by the water regime, that is, during the months of higher rainfall, the ion concentrations are reduced while during the months of lower precipitation, the concentrations increase considerably. In the present study, the highest concentrations were recorded in the months of September, April and May, coinciding with the lowest rainfall. Other studies report the same behavior as in the case of Su et al. (2019) who monitored the chemical variation of rainwater in the different partitions in a mixed evergreen and deciduous broadleaved forest in Central China. 
Table 1. Chemical characteristics of water in precipitation, throughfall and stemflow during the monitoring period.

\begin{tabular}{|c|c|c|c|}
\hline \multirow{2}{*}{ Ion } & \multicolumn{3}{|c|}{ Concentration $\left(\mathrm{mg} \mathrm{L}^{-1}\right)$} \\
\hline & Precipitation & Throughfall & Stemflow \\
\hline \multicolumn{4}{|c|}{ Without exclusion } \\
\hline$* \mathrm{Cl}^{-}$ & $0.55 \pm 0.09^{a}$ & $1.97 \pm 0.55^{b}$ & $3.86 \pm 0.73^{c}$ \\
\hline $\mathrm{N}-\mathrm{NO}_{2}^{-}$ & $0.04 \pm 0.00^{\mathrm{a}}$ & $0.04 \pm 0.00^{\mathrm{a}}$ & n.d \\
\hline $\mathrm{N}-\mathrm{NO}_{3}^{-}$ & $0.12 \pm 0.03^{\mathrm{a}}$ & $0.16 \pm 0.04^{\mathrm{a}}$ & $0.15 \pm 0.04^{\mathrm{a}}$ \\
\hline $\mathrm{P}-\mathrm{PO}_{4}{ }^{3-}$ & $0.06 \pm 0.00^{\mathrm{a}}$ & $0.07 \pm 0.00^{\mathrm{a}}$ & $0.08 \pm 0.00^{\mathrm{a}}$ \\
\hline$* \mathrm{SO}_{4}{ }^{2-}$ & $0.15 \pm 0.02^{b}$ & $0.15 \pm 0.02^{b}$ & $0.08 \pm 0.01^{\mathrm{a}}$ \\
\hline$* \mathrm{Na}^{+}$ & $0.78 \pm 0.36^{\mathrm{a}}$ & $0.78 \pm 0.25^{\mathrm{a}}$ & $1.69 \pm 0.29^{b}$ \\
\hline$* \mathrm{~N}-\mathrm{NH}_{4}{ }^{+}$ & $0.13 \pm 0.05^{\mathrm{a}}$ & $0.16 \pm 0.03^{\mathrm{a}}$ & $0.27 \pm 0.03^{b}$ \\
\hline$* \mathrm{~K}^{+}$ & $0.94 \pm 0.43^{\mathrm{a}}$ & $2.51 \pm 0.69^{b}$ & $5.42 \pm 0.83^{c}$ \\
\hline$* \mathrm{Mg}^{2+}$ & $0.30 \pm 0.12^{\mathrm{a}}$ & $0.32 \pm 0.08^{\mathrm{a}}$ & $1.23 \pm 0.18^{b}$ \\
\hline$* \mathrm{Ca}^{2+}$ & $2.44 \pm 0.57^{\mathrm{b}}$ & $0.99 \pm 0.20^{\mathrm{a}}$ & $1.69 \pm 0.33^{b}$ \\
\hline \multirow{2}{*}{ Ion } & Precipitation & Throughfall & Stemflow \\
\hline & \multicolumn{3}{|c|}{ Exclusion } \\
\hline$* \mathrm{Cl}^{-}$ & $0.55 \pm 0.09^{\mathrm{a}}$ & $1.49 \pm 0.35^{b}$ & $4.19 \pm 0.93^{c}$ \\
\hline $\mathrm{N}-\mathrm{NO}_{2}^{-}$ & $0.04 \pm 0.00^{\mathrm{a}}$ & $0.04 \pm 0.01^{\mathrm{a}}$ & $0.06 \pm 0.00^{\mathrm{a}}$ \\
\hline$* \mathrm{~N}-\mathrm{NO}_{3}{ }^{-}$ & $0.12 \pm 0.03^{a}$ & $0.17 \pm 0.05^{a b}$ & $0.24 \pm 0.09^{b}$ \\
\hline $\mathrm{P}-\mathrm{PO}_{4}{ }^{3-}$ & $0.06 \pm 0.00^{\mathrm{a}}$ & $0.05 \pm 0.00^{\mathrm{a}}$ & $0.05 \pm 0.00^{\mathrm{a}}$ \\
\hline$* \mathrm{SO}_{4}{ }^{2-}$ & $0.15 \pm 0.02^{b}$ & $0.14 \pm 0.02^{b}$ & $0.08 \pm 0.01^{\mathrm{a}}$ \\
\hline$* \mathrm{Na}^{+}$ & $0.78 \pm 0.36^{\mathrm{a}}$ & $0.75 \pm 0.22^{a}$ & $1.83 \pm 0.33^{b}$ \\
\hline$* \mathrm{~N}-\mathrm{NH}_{4}{ }^{+}$ & $0.13 \pm 0.05^{\mathrm{ab}}$ & $0.09 \pm 0.02^{\mathrm{a}}$ & $0.19 \pm 0.06^{b}$ \\
\hline$* \mathrm{~K}^{+}$ & $0.94 \pm 0.43^{\mathrm{a}}$ & $2.71 \pm 0.53^{b}$ & $6.27 \pm 0.96^{c}$ \\
\hline$* \mathrm{Mg}^{2+}$ & $0.30 \pm 0.12^{\mathrm{a}}$ & $0.36 \pm 0.09^{a}$ & $1.45 \pm 0.23^{b}$ \\
\hline$* \mathrm{Ca}^{2+}$ & $2.44 \pm 0.57^{\mathrm{c}}$ & $0.79 \pm 0.18^{\mathrm{a}}$ & $1.66 \pm 0.33^{b}$ \\
\hline
\end{tabular}

(*) Different letters in the same row indicate statistical differences at $\mathrm{p}<0.05$.

The verification of the ion dilution effect as a function of the precipitated rainfall volume 
is verified with the Pearson correlation test presented in Table 2. Mostly, a negative correlation was observed for more than $90 \%$ of the ions in the different precipitation partitions. In addition, there were strong significant correlations to a $<1 \%$ error probability for $\mathrm{K}^{+}, \mathrm{Ca}^{2+}$ and $\mathrm{Mg}^{2+}$ ions and for many throughfall ions.

Table 2. Pearson's correlation between ion concentration and measured water volume.

\begin{tabular}{cccccc}
\hline & \multicolumn{5}{c}{ Measured volume } \\
\cline { 2 - 6 } & $\mathrm{R}$ & $\mathrm{Tf}$ WE & $\mathrm{TfE}$ & $\mathrm{Sf} \mathrm{WE}$ & $\mathrm{SfE}$ \\
\hline $\mathrm{Cl}^{-}$ & -0.31 & $-0.70^{* *}$ & $-0.62^{*}$ & $-0.51^{*}$ & -0.48 \\
$\mathrm{NO}_{2}{ }^{-}$ & $0.56^{*}$ & $1.00^{* *}$ & 0.24 & - & - \\
$\mathrm{NO}_{3}{ }^{-}$ & -0.38 & -0.15 & -0.22 & -0.37 & $-0.53^{*}$ \\
$\mathrm{PO}_{4}{ }^{3-}$ & 0.05 & $-0.90^{* *}$ & - & 0.35 & $1.00^{* *}$ \\
$\mathrm{SO}_{4}{ }^{2-}$ & $-0.54^{*}$ & -0.46 & -0.29 & -0.05 & 0.06 \\
$\mathrm{Na}^{+}$ & -0.36 & -0.41 & $-0.53^{*}$ & $-0.55^{*}$ & -0.40 \\
$\mathrm{NH}_{4}^{+}$ & $-0.51^{*}$ & -0.20 & 0.28 & -0.49 & -0.35 \\
$\mathrm{~K}^{+}$ & -0.41 & $-0.78^{* *}$ & $-0.67^{*}$ & $-0.64 *$ & $-0.72^{* *}$ \\
$\mathrm{Mg}^{2+}$ & $-0.62^{*}$ & $-0.64^{*}$ & $-0.51^{*}$ & $-0.61^{*}$ & $-0.76^{* *}$ \\
$\mathrm{Ca}^{2+}$ & -0.43 & $-0.72^{* *}$ & $-0.53^{*}$ & $-0.73^{* *}$ & $-0.76^{* *}$ \\
\hline
\end{tabular}

**. Correlation is significant at the 0.01 level (2-tailled).

*. Correlation is significant at the 0.05 level (2-tailled).

Figure 5 shows in detail the variation in ion concentration over the monitored period for the different partitions of rainfall. As can be seen, for most ions there are two months of prominence: September and May.

The order of the ion contents in rainfall was: $\mathrm{Ca}^{2+}>\mathrm{K}^{+}>\mathrm{Na}^{+}>\mathrm{Cl}^{-}>\mathrm{Mg}^{2+}>\mathrm{SO}_{4}{ }^{2-}>\mathrm{N}-$ $\mathrm{NH}_{4}{ }^{+}>\mathrm{N}-\mathrm{NO}_{3}{ }^{-}>\mathrm{P}_{-} \mathrm{PO}_{4}{ }^{3-}>\mathrm{N}-\mathrm{NO}_{2}$. In the throughfall for the WE treatment, it was: $\mathrm{K}^{+}>\mathrm{Cl}^{-}>$ $\mathrm{Ca}^{2+}>\mathrm{Na}^{+}>\mathrm{Mg}^{2+}>\mathrm{N}^{2} \mathrm{NO}_{3}{ }^{-}>\mathrm{N}_{-}-\mathrm{NH}_{4}{ }^{+}>\mathrm{SO}_{4}{ }^{2-}>\mathrm{P}_{-} \mathrm{PO}_{4}{ }^{3}>\mathrm{N}-\mathrm{NO}_{2}{ }^{-}$. In the throughfall for the E treatment, it was: $\mathrm{K}^{+}>\mathrm{Cl}^{-}>\mathrm{Ca}^{2+}>\mathrm{Na}^{+}>\mathrm{Mg}^{2+}>\mathrm{N}^{2} \mathrm{NO}_{3}{ }^{-}>\mathrm{SO}_{4}{ }^{2-}>\mathrm{N}-\mathrm{NH}_{4}{ }^{+}>\mathrm{P}_{-} \mathrm{PO}_{4}{ }^{3}>\mathrm{N}-$ $\mathrm{NO}_{2}$.

For stemflow, the ion concentration was $\mathrm{K}^{+}>\mathrm{Cl}^{-}>\mathrm{Na}^{+}>\mathrm{Ca}^{2+}>\mathrm{Mg}^{2+}>\mathrm{N}_{-} \mathrm{NH}_{4}^{+}>\mathrm{N}-$ $\mathrm{NO}_{3}{ }^{-}>\mathrm{SO}_{4}{ }^{2-}>\mathrm{P}-\mathrm{PO}_{4}{ }^{3}>\mathrm{N}-\mathrm{NO}_{2}{ }^{-}$for the treatment without exclusion and $\mathrm{K}^{+}>\mathrm{Cl}^{-}>\mathrm{Na}^{+}>\mathrm{Ca}^{2+}$ $>\mathrm{Mg}^{2+}>\mathrm{N}-\mathrm{NO}_{3}{ }^{-}>\mathrm{N}-\mathrm{NH}_{4}{ }^{+}>\mathrm{SO}_{4}{ }^{2-}>\mathrm{N}-\mathrm{NO}_{2}{ }^{-}>\mathrm{P}_{-} \mathrm{PO}_{4}{ }^{3}$ for treatment with partial removal of throughfall.

Our results clearly show an increase in the contents of certain nutrients as the rainwater interacts with the forest canopy. Balieiro et al. (2007), evaluating a Eucalyptus stand in Seropédica, RJ found concentrations $\left(\mathrm{mg} \mathrm{L}^{-1}\right)$ of $0.82 ; 0.20 ; 3.52 ; 0.62 ; 0.39$ and 1.44 for N$\mathrm{NH}_{4}^{+}, \mathrm{P}, \mathrm{K}^{+}, \mathrm{Ca}^{2+}, \mathrm{Mg}^{2+}$ and $\mathrm{Na}^{+}$, respectively. For throughfall, the concentrations of $1.38 ; 0.33$; 14.83; 0.94; 0.96 and $3.78 \mathrm{mg} \mathrm{L}^{-1}$, for $\mathrm{N}^{-N_{H}}{ }^{+}, \mathrm{P}^{+} \mathrm{K}^{+}, \mathrm{Ca}^{2+}, \mathrm{Mg}^{2+}$ and $\mathrm{Na}^{+}$, respectively. In stemflow, the concentrations were as follows: $2.28 ; 0.40 ; 14.17 ; 0.75 ; 1.42$ and 2.73 for $\mathrm{N}$ $\mathrm{NH}_{4}^{+}, \mathrm{P}, \mathrm{K}^{+}, \mathrm{Ca}^{2+}, \mathrm{Mg}^{2+}$ and $\mathrm{Na}^{+}$, respectively. 

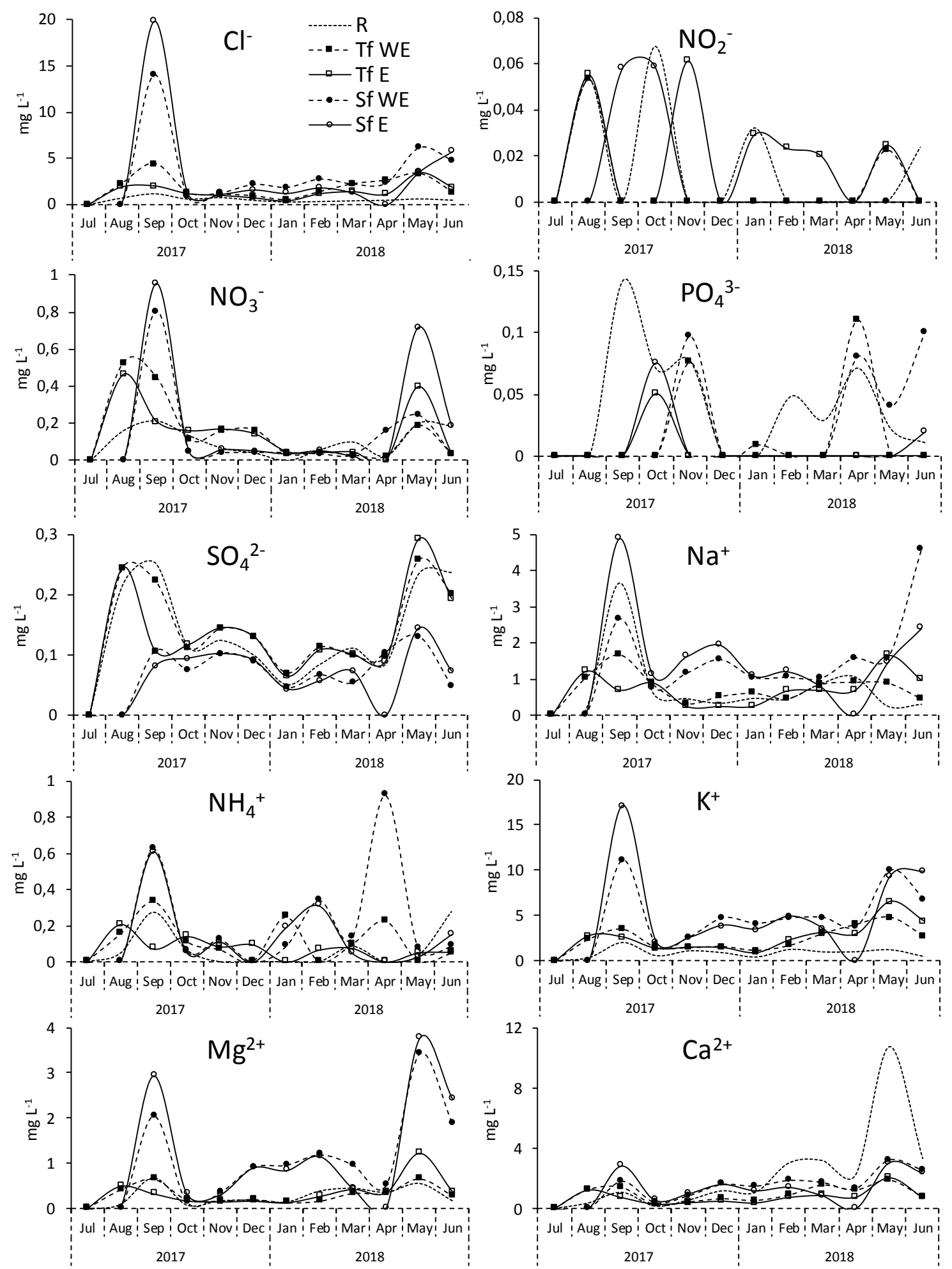

Figure 5. Monthly variation in ion concentration in different precipitation partitions.

\subsection{Nutrient input}

The rainfall had a total nutrient input of $55.69 \mathrm{~kg} \mathrm{ha}^{-1} \mathrm{yr}^{-1}$. For throughfall, the contribution was $60.20 \mathrm{~kg} \mathrm{ha}^{-1}$ and $36.27 \mathrm{~kg} \mathrm{ha}^{-1}$ for TfWE and TfE, respectively. The significant reduction in the amount of nutrients in treatment $E$ refers to the fact that these nutrients are being carried out of the stand due to the system of excluding water from rainfall. For stemflow, the contribution was greater, with $3.96 \mathrm{~kg} \mathrm{ha}^{-1}$ in the SfWE and 3.36 in the SfE (Figure 6). 

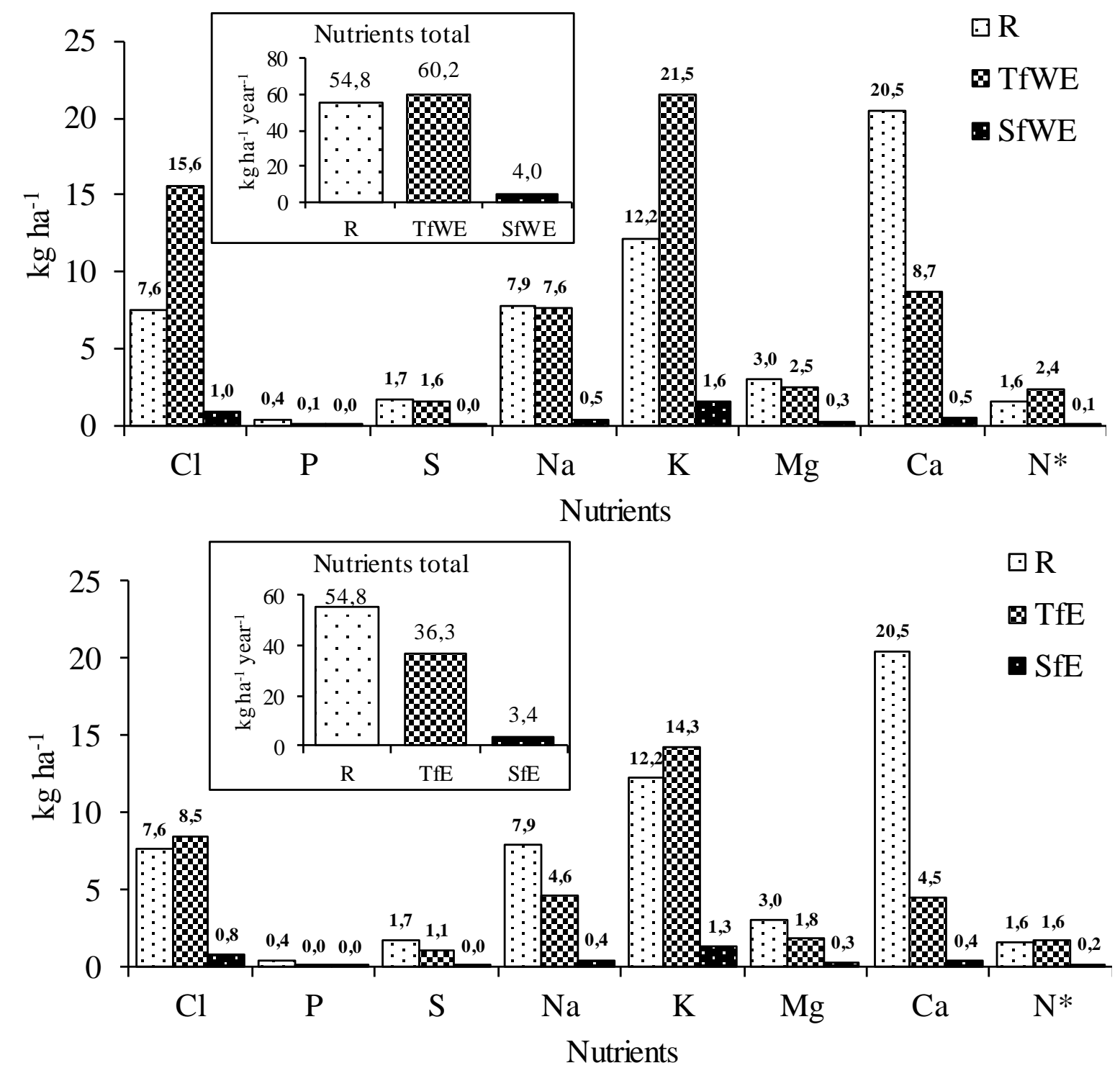

Figure 6. Annual amount of nutrients $\left(\mathrm{kg} \mathrm{ha}^{-1} \mathrm{yr}^{-1}\right)$ incorporated into the system by rainfall (R), throughfall (Tf) and stemflow (Sf) in a stand of the hybrid Eucalyptus urophylla x E. sp.

$* \mathrm{~N}$ total $=\mathrm{NO}_{2}{ }^{-}+\mathrm{NO}_{3}{ }^{-}+\mathrm{NH}_{4}{ }^{+}$.

The flow of nutrients in rainfall had the following distribution order: $\mathrm{Ca}>\mathrm{K}>\mathrm{Na}>\mathrm{Cl}>$ $\mathrm{Mg}>\mathrm{S}>\mathrm{N}>\mathrm{P}$. In Tf WE, the order was as follows: $\mathrm{K}>\mathrm{Cl}>\mathrm{Ca}>\mathrm{Na}>\mathrm{Mg}>\mathrm{N}>\mathrm{S}>\mathrm{P}$. In the $\mathrm{Sf}$ $\mathrm{WE}, \mathrm{K}>\mathrm{Cl}>\mathrm{Ca}>\mathrm{Na}>\mathrm{Mg}>\mathrm{N}>\mathrm{S}>\mathrm{P}$. The Tf E presented the following order: $\mathrm{K}>\mathrm{Cl}>\mathrm{Na}>$ $\mathrm{Ca}>\mathrm{Mg}>\mathrm{N}>\mathrm{S}>\mathrm{P}$. For $\mathrm{SfE} \mathrm{K}>\mathrm{Cl}>\mathrm{Na}>\mathrm{Ca}>\mathrm{Mg}>\mathrm{N}>\mathrm{S}>\mathrm{P}$. Considering the sum of throughfall plus stemflow in the WE treatment the amount of nutrients $\left(\mathrm{kg} \mathrm{ha}^{-1}\right)$ was 16.6 for $\mathrm{Cl}, 0.1$ for $\mathrm{P}, 1.7$ for $\mathrm{S}, 8.1$ for $\mathrm{Na}, 23.1$ for $\mathrm{K}, 2.9$ for $\mathrm{Mg}, 9.2$ for $\mathrm{Ca}$ and 2.5 for $\mathrm{N}$. As for treatment $\mathrm{E}$, there was a contribution $\left(\mathrm{kg} \mathrm{ha}^{-1} \mathrm{yr}^{-1}\right)$ of 9.3 for $\mathrm{Cl}, 0.02$ for $\mathrm{P}, 1.1$ for $\mathrm{S}, 5.0$ for $\mathrm{Na}, 15.6$ for $\mathrm{K}, 2.1$ for $\mathrm{Mg}$, 4.9 for $\mathrm{Ca}, 1.8$ for $\mathrm{N}$.

Regarding nutrient input via rainfall, it was observed that there was a significant increase in nutrients in the aqueous solution, whose input sequence was $\mathrm{K}>\mathrm{S}>\mathrm{Ca}>\mathrm{N}>\mathrm{Mg}$. These inputs could reduce the addition of $22 \%$ and $11 \%$ of the amounts of $\mathrm{K}$ and $\mathrm{N}$, respectively, applied to pre-planting fertilization (Dick et al., 2018). The annual contribution of nutrients in the present study is similar to that found by Momolli et al., (2020). For these authors, the annual contribution was $36.3 \mathrm{~kg} \mathrm{ha}^{-1}$. This small variation is justified according to the conditions: close to the ocean, emission of atmospheric pollutants by anthropic activity and even soil and environmental characteristics (Corti et al., 2019; Yuan et al., 2017). Possibly, the greatest 
contribution of certain nutrients is related to the existence of two pulp mills, the first approximately $12 \mathrm{~km}$ away in a straight line located in the municipality of Telêmaco Borba, PR and the second approximately $21 \mathrm{~km}$ away in the municipality of Ortigueira, PR. Balieiro et al. (2007) in an Eucalyptus stand found a contribution $\left(\mathrm{kg} \mathrm{ha}^{-1}\right)$ via rainfall of $12.07 \mathrm{~N}^{-\mathrm{NH}_{4}}{ }^{+} ; 2.65$ P; 86.00 K+; $12.25 \mathrm{Ca}^{2+} ; 9.24 \mathrm{Mg}^{2+} ; 29.81 \mathrm{Na}^{+}$.

The increase in the amount of nutrients after interaction with the canopy is more significant for $\mathrm{K}^{+}$, which can be attributed to the high levels due to leaching of the canopy of the trees. However, some ions do not exhibit the same behavior as $\mathrm{SO}_{4}{ }^{2-}$. The input via rainfall was 1.7 $\mathrm{kg} \mathrm{ha}^{-1}$ and $1.6 \mathrm{~kg} \mathrm{ha}^{-1}$ via TfWE. According to Gay and Murphy (1985), approximately between $30-70 \%$ of the dry deposition of $\mathrm{SO}_{4}{ }^{2-}$ can be retained in the canopy. Corrêa et al. (2019) evaluating an E. dunni stand 16.5 months old, found that due to the concentration of ions there was a greater contribution of elements after the interaction of precipitation with the forest canopy.

\section{CONCLUSION}

There was an enrichment of nutrients as the water interacted with the forest canopy. Considering the average levels of ions, the degree of enrichment had the following decreasing order: stemflow > throughfall > rainfall. The concentration of ions is seasonal and is especially determined by the volume of water in each partition causing the dilution effect.

The total quantity of nutrients contributed had the following order: throughfall > rainfall > stemflow. The reduction of the water treatment system in partial exclusion of precipitation (E) reduced representative nutrient input. It is important to highlight that although stemflow represents on average only $2.6 \%$ of the water volume, it is responsible for $6.7 \%$ of the amount of nutrients in relation to precipitation. Therefore, stemflow cannot be neglected in the balance of nutrient cycling.

Considering the interaction of rainwater with canopy, in a 7-year rotation there is a potential reduction of chemical fertilizers. These results point the way to greater economic and environmental sustainability.

\section{ACKNOWLEDGEMENTS}

This study was financed in part by the Coordenação de Aperfeiçoamento de Pessoal de Nível Superior - Brasil (CAPES) - Finance Code 001.

\section{DATA AVAILABILITY STATEMENT}

The data that support the findings of this study are available on request from the corresponding author. The data are not publicly available due to privacy or ethical restrictions.

\section{REFERENCES}

ALLAN, R. P.; SODEN, B. J. Atmospheric warming and the amplification of precipitation extremes. Science, v. 321, p. 1481-1484, 2008. https://doi.org/10.1126/science.1160787

ALVARES, C. A. et al. Köppen's climate classification map for Brazil. Meteorologische Zeitschrift, v. 22, n. 6, p. 711-728, 2014. https://doi.org/10.1127/0941-2948/2013/0507

ANDRE, F.; JONARD, M.; PONETTE, Q. Effects of biological and meteorological factors on stemflow chemistry within a temperate mixed oak-beech stand. Science of the Total Environment, v. 393, p. 72-83, 2008. https://doi.org/10.1016/j.scitotenv.2007.12.002 
APHA; AWWA; WEF. Standard Methods for the Examination of Water and Wastewater. 20. ed. Washington, 1998.

BALIEIRO, F. C.; FRANCO, A. A.; FONTES, R. L. F.; DIAS, L. E.; CAMPELLO, E. F. C.; FARIA, S. M. Evaluation of the throughfall stemflow nutrient contents in mixed and pure plantations of Acacia mangium, Pseudosamenea guachapele and Eucalyptus grandis. Revista Árvore, v. 31 n. 2, p. 339-346, 2007. https://doi.org/10.1590/S010067622007000200017

BINKLEY, D.; CAMPOE, O. C.; ALVARES, C.; CARNEIRO, R. L.; CEGATTA, Í; STAPE, J. L. The interactions of climate, spacing and genetics on clonal Eucalyptus plantations across Brazil and Uruguay. Forest Ecology and Management, v. 405, p. 271-283, 2017. https://doi.org/10.1016/j.foreco.2017.09.050

BHAT, S.; JACOBS, J.; BRYANT, M. The chemical composition of rainfall and throughfall in five forest communities: A case study in Fort Benning, Georgia. Water, Air, \& Soil Pollution, v. 218, p. 323-332, 2011. https://doi.org/10.1007/s11270-010-0644-1

CHAFFE, P. L. B.; KOBIYAMA, M.; YAMASHIKI, K.; TAKARA, K. Is interception information important for rainfall runoff modeling? Annual Journal of Hydraulic Engineering, v. 54, p. 73-78, 2010.

CORRÊA, R. S.; SCHUMACHER, M. V.; MOMOLLI, D. R.; BERGER, C. Aspectos da precipitação pluviométrica em um povoamento jovem de Eucalyptus dunnii no Bioma Pampa. Advances in Forestry Science, v. 6, n. 3, p. 717-721, 2019. http://dx.doi.org/10.34062/afs.v6i3.7617

CORTI, G.; AGNELLI, A.; COCCO, S.; CARDELLI, V.; MASSE, J.; COURCHESNE, F. Soil a_ects throughfall and stemflow under Turkey oak (Quercus cerris L.). Geoderma, v. 333, p. 43-56, 2019.

DAWOE, E. K.; BARNES, V. R.; OPPONG, S. K. Spatio-temporal dynamics of gross rainfall partitioning and nutrient fluxes in shaded-cocoa (Theobroma cocoa) systems in a tropical semi-deciduous forest. Agroforestry Systems, v. 92, p. 397-413, 2018. https://doi.org/10.1007/s10457-017-0108-3

DICK, G. et al. Nutrient input via incident rainfall in a Eucalyptus dunnii stand in the Pama Biome. Floresta e Ambiente, v. 25, n. 3, 2018. https://doi.org/10.1590/21798087.055916

FAN, J. L.; OESTERGAARD, K. T.; GUYOT, A.; JENSEN, D. G.; LOCKINGTON, D. A. Spatial variability of throughfall and stemflow in an exotic pine plantation of subtropical coastal Australia. Hydrological Processes, v. 29, p. 793-804, 2015. https://doi.org/10.1002/hyp.10193

FERRAZ, S. F. B.; RODRIGUES, C. B.; GARCIA, L. G.; ALVARES, C. A.; DE PAULA LIMA, W. Effects of Eucalyptus plantations on streamflow in Brazil: Moving beyond the water use debate. Forest Ecology and Management, v. 453, p. 117571, 2019.

FLORES, T. B. et al. Eucalyptus no Brasil: zoneamento climático e guia para identificação. Piracicaba: IPEF, 2016. 448p.

GAY, D. W.; MURPHY, C. E. The Deposition of SO44- on Forests (Final Report, EPRI Project R.P. 1813-2). Palo Alto: Electric Power Research Institute, 1985.

IBÁ. Relatório anual 2020: ano base 2019. São Paulo: 2020. 66 p. 
JOHNSON, M. S.; LEHMANN, J. Double-funneling of trees: Stemflow and root-induced preferential flow. Ecoscience, v. 13, p. 324-333, 2006. https://doi.org/10.2980/i11956860-13-3-324.1

LEVIA, D. F.; KEIM, R. F.; CARLYLE-MOSES, D. E.; FROST, E. E. Throughfall and stemflow in wooded ecosystems. In: LEVIA, D.; CARLYLE-MOSES, D.; TANAKA, T. (eds.). Forest Hydrology and Biogeochemistry: Synthesis of Past Research and Future Directions. Ecological Studies, 216). Dordrecht: Springer, 2011. https://doi.org/10.1007/978-94-007-1363-5

LIKENS, G.E. Biogeochemistry of a Forested Ecosystem. Berlin: Springer Science \& Business Media, 2013.

LLORENS, P.; DOMINGO, F. Rainfall partitioning by vegetation under Mediterranean conditions: A review of studies in Europe. Journal of Hydrology, v. 335, p. 37-54, 2007. https://doi.org/10.1016/j.jhydrol.2006.10.032

LU, J.; ZHANG, S.; FANG, J.; YAN, H.; LI, J. Nutrient fluxes in rainfall, throughfall, and stemflow in Pinus densata natural forest of Tibetan Plateau. Clean Soil Air Water, v. 45, p. 1600008, 2017. https://doi.org/10.1002/clen.201600008

MOMOLLI, D. R.; SCHUMACHER, M. V.; VIERA, M.; LUDVICHAK, A. A.; GUIMARÃES, C. C.; SOUZA, H. P. Incident precipitation partitioning: throughfall, stemflow and canopy interception in Eucalyptus dunnii stand. Journal of Agricultural Science, v. 11, n. 5, 2019a. https://doi.org/10.5539/jas.v11n5p372

MOMOLLI, D. R.; SCHUMACHER, M. V.; VIERA, M.; LUDVICHAK, A. A.; GUIMARÃES, C. C.; SOUZA, H. P. Incident Precipitation Partitioning: The Canopy Interactions Enrich Water Solution with Nutrients in Throughfall and Stemflow. Journal of Agricultural Science, v. 11, n. 6, 2019b. https://doi.org/10.5539/jas.v11n6p351

MOMOLLI, D. R.; SOUZA, H. P.; SCHUMACHER, M. V.; LUDVICHAK, A. P.; GUIMARÃES, C. C.; MALHEIROS, A. C.; GONSALVES, J. M. W. Seasonal variation of atmospheric nutrient deposition in the western part of Rio Grande do Sul, Brazil. Revista Ambiente \& Água, v. 15, n. 3, 2020. https://doi.org/10.4136/ambi-agua.2524

NAVAR, J.; GONZALEZ, J. M.; GONZALEZ, H. Gross precipitation and throughfall chemistry in legume species planted in Northeastern Mexico. Plant Soil, v. 318, p. 1526, 2009. https://doi.org/10.1007/s11104-008-9812-0

NAVAR, J. Stemflow variation in Mexico's northeastern forest communities: Its contribution to soil moisture content and aquifer recharge. Journal of Hydrology, v. 408, n.1, p. 35 42, 2011. https://doi.org/10.1016/j.jhydrol.2011.07.006

POLETO, G. C.; MOMOLLI, D. R.; SCHUMACHER, M. V.; LUDVICHAK, A. A.; SANTOS, K. F.; STAHL, J.; ALVARES, C. A. Partial exclusion of precipitation: throughfall, stemflow and canopy interception in Eucalyptus plantations in southern Brazil. Revista Ambiente \& Água, v. 16, n. 5, 2021. https://doi.org/10.4136/ambiagua. 2645

PREUHSLER, T.; BASTRUP-BIRK, A.; BEUKER, E. (elab.). Meteorological Measurements. In: United Nations Economic Commission for Europe. Manual on methods and criteria for harmonized sampling, assessment, monitoring and analysis of the effects of air pollution on forests. Part VII. 2006. Available at: https://www.icpforests.org/pdf/manual/2000/Chapt7_compl2006.pdf Access: Oct. 2021. 
SCHRUMPF, M.; ZECH, W.; AXMACHER, J.; HERBERT V. M. L. Biogeochemistry of an Afrotropical Montane Rain Forest on Mt. Kilimanjaro, Tanzania. Journal of Tropical Ecology, v. 22, n. 1, p. 77-89. 2006. http://www.jstor.org/stable/4092145

STAELENS, J.; DE SCHRIJVER, A.; VERHEYEN, K.; VERHOEST, N. E. C. Spatial variability and temporal stability of throughfall water under a dominant beech (Fagus sylvatica L.) tree in relationship to canopy cover. Journal of Hydrology, v. 330, p. 651662, 2006. https://doi.org/10.1016/j.jhydrol.2006.04.032

SU, L.; ZHAO, C.; XU, W.; XIE, Z. Hydrochemical Fluxes in Bulk Precipitation, Throughfall, and Stemflow in a Mixed Evergreen and Deciduous Broadleaved Forest. Forests, v. 10, n. 507, 2019. https://doi.org/10.3390/f10060507

SWAFFER, B. A.; HOLLAND, K. L.; DOODY, T. M.; HUTSON, J. Rainfall partitioning, tree form and measurement scale: A comparison of two co-occurring, morphologically distinct tree species in a semi-arid environment. Ecohydrology, v. 7, p. 1331-1344, 2014. https://doi.org/10.1002/eco.1461

TIWARI, S. et al. Nature and Sources of Ionic Species in Precipitation across the Indo-Gangetic Plains, India. Aerosol and Air Quality Research, v. 16, n.4, p. 943.957, 2016. https://doi.org/10.4209/aaqr.2015.06.0423

VIERA, M.; SCHUMACHER, M. V. Deposição de serapilheira e de macronutrientes em um povoamento de acácia negra (Acacia mearnsii De Wild.) no Rio Grande do Sul. Ciência Florestal, v. 20, n.2, p. 225-233, 2010. https://doi.org/10.5902/198050981848

ZHANG, Y.; WANG, X.; HU, R.; PAN, Y.; ZHANG, H. Stemflow in two xerophytic shrubs and its significance to soil water and nutrient enrichment. Ecological Research, v. 28, p. 567-579, 2013. https://doi.org/10.1007/s11284-013-1046-9

ZHANG, Y.; WANG, X.; PAN, Y.; HU, R. Variations of Nutrients in Gross Rainfall, Stemflow, and Throughfall Within Revegetated Desert Ecosystems. Water Air Soil Pollution, v. 227, n. 6, p. 183, 2016. https://doi.org/10.1007/s11270-016-2878-z

ZHOU, X. et al. Chemical composition of precipitation in Shenzhen, a coastal mega-city in South China: Influence of urbanization and anthropogenic activities on acidity and ionic composition. Science of The Total Environment, v. 662, p. 218.226, 2019. https://doi.org/10.1016/j.scitotenv.2019.01.096

YUAN, C.; GAO, G.; FU, B. Comparisons of stemflow and its bio-/abiotic influential factors between two xerophytic shrub species. Hydrology and Earth System Sciences, v. 21, p. 1421-1438, 2017. https://doi.org/10.5194/hess-21-1421-2017 


\begin{tabular}{|} 
Ambiente \& Água - An Interdisciplinary Journal of Applied Science \\
ISSN 1980-993X - doi:10.4136/1980-993X \\
www.ambi-agua.net \\
E-mail: ambi.agua@gmail.com
\end{tabular}

\title{
Artificial floating islands as a tool for the water quality improvement of fishponds
}

\author{
ARTICLES doi:10.4136/ambi-agua.2734
}

Received: 08 Apr. 2021; Accepted: 10 Nov. 2021

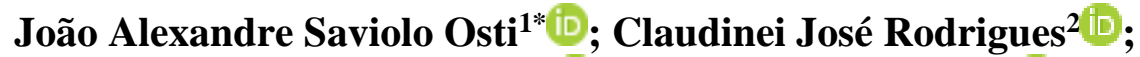

Clovis Ferreira do Carmo ${ }^{3}$; Ana Carolina Peixoto ${ }^{1}$;

Sergio Henrique Canello Schalch ${ }^{4}$; Adriana Sacioto Marcantonio ${ }^{4}$;

Fernanda Menezes França ${ }^{4}$; Cacilda Thais Janson Mercante ${ }^{3(i)}$
${ }^{\mathbf{1}}$ Mestrado em Análise Geoambiental. Universidade Guarulhos (UNG), Praça Tereza Cristina, ${ }^{\circ} 239$, CEP: 07023-070, Guarulhos, SP, Brazil. E-mail: carol.peixoto2009@gmail.com
${ }^{2}$ Instituto Chico Mendes de Conservação da Biodiversidade (ICMBio). Estação Ecológica de Carijós, Rodovia Jornalista Maurício Sirotski Sobrinho, km 2, CEP: 88053-700, Florianópolis, SC, Brazil.
E-mail: claudinei.rodrigues@icmbio.gov.br São Paulo, SP, Brazil. E-mail: clovis@pesca.sp.gov.br, cacilda.mercante@sp.gov.br
Pindamonhangaba, SP, Brazil. E-mail: sschalch@apta.sp.gov.br, adriana.sacioto@gmail.com, fernanda_ranicultura@yahoo.com.br
*Corresponding author. E-mail: jale.osti@gmail.com

${ }^{3}$ Instituto de Pesca. Agência Paulista de Tecnologia dos Agronegócios (APTA). Secretaria de Agricultura e Abastecimento (SAA), Praça Ramos de Azevedo, n² 254, CEP: 01037-912, Centro Histórico de São Paulo,

${ }^{4}$ Polo Regional Vale do Paraíba. Agência Paulista de Tecnologia dos Agronegócios (APTA). Secretaria de

Agricultura e Abastecimento (SAA). Avenida Professor Manoel César Ribeiro, n ${ }^{\circ}$ 1920, CEP: 12411010,
\end{abstract}

\begin{abstract}
In this study, the ecotechnology artificial floating islands (AFIs), colonized by Eichhornia crassipes, have been tested as a tool for water quality improvement of fishponds. The experiment was carried out in semi-intensive production during the grow-out period of Nile tilapia, comprising one production cycle. It was completely randomized with two treatments (with and without AFIs) and three replications. Temperature, dissolved oxygen, conductivity, $\mathrm{pH}$, turbidity, total dissolved solids (TDS), transparency (Secchi) and concentrations of chlorophyll $a(\mathrm{CL} a)$, total nitrogen (TN), total ammonia nitrogen (TAN), total phosphorus (TP) and orthophosphate $\left(\mathrm{PO}_{4}{ }^{3-}-\mathrm{P}\right)$ were analyzed fortnightly in the fishponds. Two groups ordered based on environmental characteristics were formed by applying the Principal Component Analysis (70.68\% of explicability). The fishponds with AFIs were assigned to higher values of Secchi and lower values of $\mathrm{pH}$, turbidity, TDS and concentrations of nutrients. On the other hand, the fishponds without AFIs were assigned to the highest values of these variables, except for Secchi. In 30 days, the AFIs showed the lowest concentrations of TP and $\mathrm{PO}_{4}{ }^{3-}-\mathrm{P}$, and for CL $a$, TN and TAN, the differences were recorded after 90 days. The use of AFIs has demonstrated potential to conserve water quality in fishponds, notably for biologically assimilable elements $\left(\mathrm{PO}_{4}{ }^{3-}-\mathrm{P}\right.$ and $\left.\mathrm{TAN}\right)$ and for those directly related to eutrophication ( $\mathrm{P}$ and $\mathrm{N}$ ). Artificial floating islands should be encouraged for small and medium-sized farmers as tool to improve water quality in fishponds. However, new AFIs coverage rates must be evaluated, as well as the control of hydraulic retention rates.
\end{abstract}

Keywords: aquaculture, ecotechnology, free-floating aquatic macrophytes.

This is an Open Access article distributed under the terms of the Creative Commons Attribution License, which permits unrestricted use, distribution, and reproduction in any medium, provided the original work is properly cited. 


\section{Ilhas flutuantes artificiais como ferramenta para melhorar a qualidade da água de viveiros de piscicultura}

\section{RESUMO}

No presente estudo, a ecotecnologia de ilhas flutuantes artificiais (IFAs) colonizadas por Eichhornia crassipes foi testada como uma ferramenta para a melhoria da qualidade da água de viveiros de peixes. O experimento foi realizado em sistemas de produção semi-intensivos durante o período de crescimento de tilápia, compreendendo um ciclo de produção. Foi completamente randomizado com dois tratamentos (com e sem IFAs) e três repetições. A temperatura da água, oxigênio dissolvido (OD), condutividade elétrica, $\mathrm{pH}$, turbidez, sólidos totais dissolvidos (STD), transparência da água (Secchi) e concentrações de clorofila $a$ (CL $a$ ), nitrogênio total (NT), nitrogênio amoniacal total (NAT), fósforo total (PT), ortofosfato $\left(\mathrm{P}-\mathrm{PO}_{4}{ }^{3}\right)$ foram analisados quinzenalmente nos viveiros. Dois grupos ordenados com base nas características ambientais foram formados por meio da aplicação da análise de componentes principais $(70,68 \%$ de explicabilidade). Aos viveiros com IFAs foram atribuídos maiores valores de Secchi e menores valores de $\mathrm{pH}$, turbidez e STD e das concentrações de CL $a$, NT, NAT, PT, P-PO ${ }_{4}^{3-}$. Aos viveiros sem IFAs foram atribuídos os maiores valores dessas variáveis, exceto Secchi. Em 30 dias, viveiros com essas variáveis apresentaram as menores concentrações de PT e P-PO ${ }_{4}^{3-}$, e para CL $a$, NT e NAT, as diferenças foram registradas após 90 dias. O uso de IFAs tem demonstrado alto potencial para manutenção da qualidade da água adequada para a produção de peixes, notadamente para elementos biologicamente assimiláveis (ortofosfato e nitrogênio amoniacal) e para aqueles diretamente relacionados à eutrofização (fósforo total, nitrogênio e Secchi). A tecnologia de IFAs deve ser encorajada para pequenos e médios produtores rurais como ferramenta para melhorar a qualidade da água de viveiros de piscicultura. Contudo, novas taxas de cobertura de IFAs devem ser avaliadas, com cuidado, bem como o controle das taxas de retenção hidráulica, para promover melhorias mais significativas na qualidade da água, sem prejudicar a produção de peixes.

Palavras-chave: aquicultura, ecotecnologia, macrófitas aquáticas livre-flutuante.

\section{INTRODUCTION}

Brazilian aquaculture has developed rapidly, attaining, in $2016,13^{\text {th }}$ place among the largest producers in the world (FAO, 2018). In 2019, fish production increased $4.9 \%$ in relation to the previous year, reaching a yield of 758,006 tons, even in a scenario of low national economic growth. This increase represents the importance of the sector for the country, which is the $4^{\text {th }}$ largest producer of tilapia in the world (PeixeBr, 2020).

The quality of water in suitable conditions for the production of aquatic organisms is an essential requirement for the success of aquaculture activities. In excavated fishponds, detailed knowledge of ecological and biological aspects and constant monitoring of environmental variables contribute to the management and maintenance of desirable water quality in aquaculture, improving the development of organisms and optimizing productivity by area (Mercante et al., 2007; Sipaúba-Tavares et al., 2015).

The feeding practices necessary to sustain semi-intensive and intensive fish farming systems contribute to the input of large amounts of nutrients into the water. No more than $25 \%$ of $\mathrm{N}$ and $30 \%$ of $\mathrm{P}$ added to fishponds as feed are converted into fish biomass (Moraes et al., 2016; Chatvijitkul et al., 2017; David et al., 2017a; 2017b; Osti et al., 2018a). Additionally, overfeeding or the use of unbalanced feed reduces the absorption of nutrients by fish, which can result in excess of organic matter and nutrients in production systems, with direct consequences on water quality, favoring their assimilation by phytoplankton and aquatic 
macrophytes. The increase in phytoplankton abundance may lead to the reduction in water transparency and depletion of dissolved oxygen, which can compromise the productivity performance and increase fish mortality (Cyrino et al., 2010; Boyd, 2016; Mercante et al., 2020).

The adoption of Best Management Practices (BMPs) and the development of technologies that combine the necessary speed for an economically viable production, without compromising the water quality of fishponds, must be adopted to ensure a suitable environment for the fish, as well as the conservation of aquatic environments, promoting the sustainability of the activity. The technology of artificial floating islands (AFIs) is an innovative variant of the built wetland system and consists of the elaboration of floating rafts that are colonized by emerging and floating aquatic macrophytes, with the roots of plants submerged below the water surface (Afzal et al., 2019; Spangler et al., 2019; Osti et al., 2020). In these systems, the improvement of water quality is due to the direct assimilation of nutrients by the root system of plants, but also by the biofilm formed by algae, bacteria and other microbes that adhere to the entire surface area of the AFIs (roots of the plants).

Plants and island (structure) aid in the assimilation of nutrients, by attenuating light, inhibiting phytoplankton growth, zooplankton herbivory and allelopathic chemical compounds produced by macrophytes (Sipaúba-Tavares et al., 2015; Park et al., 2018; Spangler et al., 2019; Kurashov et al., 2021). The technology of AFIs has been tested in the control of pollution from different activities, such as swine waste (Hubbard et al., 2004); in rainwater drainage systems (Headley et al., 2008; Lynch et al., 2015); and at acid mine drainage sites (Gupta et al., 2020). Furthermore, the adequacy of this technology was also tested to control the release of nutrients by fishponds' effluents (Osti et al., 2020). These authors concluded that AFIs technology implemented in fishponds can reduce the load of total nitrogen and total phosphorus exported by $66 \%$ and $27 \%$, respectively, showing its efficiency. Likewise, the studies cited above have shown that AFIs technology has become an environmentally viable option for removing nutrients and metals from water and/or retaining particulate matter in suspension from different polluting sources. However, information on the influence of AFIs implementation aiming at the maintenance of water quality of fishponds, as well as the ideal development of fish in production systems, is still a challenge. Thus, in this study, the authors have evaluated the effect of AFIs implementation, colonized by Eichhornia crassipes, on the water quality of Nile tilapia fishponds and on the development of these animals during the grow-out period.

\section{MATERIALS AND METHODS}

\subsection{Study area}

This study was carried out for 133 days (November 2018 to April 2019) in six fishponds producing Nile tilapia located at the Experimental Station of the Regional Pole for Technological Development of the Paraíba Valley Agribusiness, Pindamonhangaba, São Paulo State, Brazil.

\subsection{Description of production system and feed management}

Six excavated earthen-bottom fishponds with $200 \mathrm{~m}^{2}$ of surface area, approximately $1.2 \mathrm{~m}$ deep and a total volume of $240 \mathrm{~m}^{3}$ were used. The water supply came from the water reservoir located inside the experimental station and the effluent was discharged into the receiving water body (Ribeirão do Borba), which is one of the sources of Ribeirão do Cortume, part of the Paraíba do Sul River Basin, SP, Brazil (Figure 1). Water renewal in the fishponds was constant, the average water residence time was $26 \mathrm{~h}$ during the experiment and there was no mechanical aeration.

The limnological characteristics of the water supply, such as water temperature $\left(26.4^{\circ} \mathrm{C}\right)$, $\mathrm{pH}(6.25)$, turbidity (25 NTU), conductivity $\left(50 \mu \mathrm{S} \mathrm{cm}^{-1}\right)$, dissolved oxygen $\left(6.88 \mathrm{mg} \mathrm{L}^{-1}\right)$ and 
total dissolved solids $\left(0.034 \mathrm{mg} \mathrm{L}^{-1}\right)$, were regularly monitored during the study period and are detailed in Osti et al. (2020). The semi-intensive production system was used for the grow-out period of male Nile tilapia (Oreochromis niloticus), sexually reversed, with an initial average weight of $22.64 \mathrm{~g}$, stocked at the density of three fish per $\mathrm{m}^{2}$.
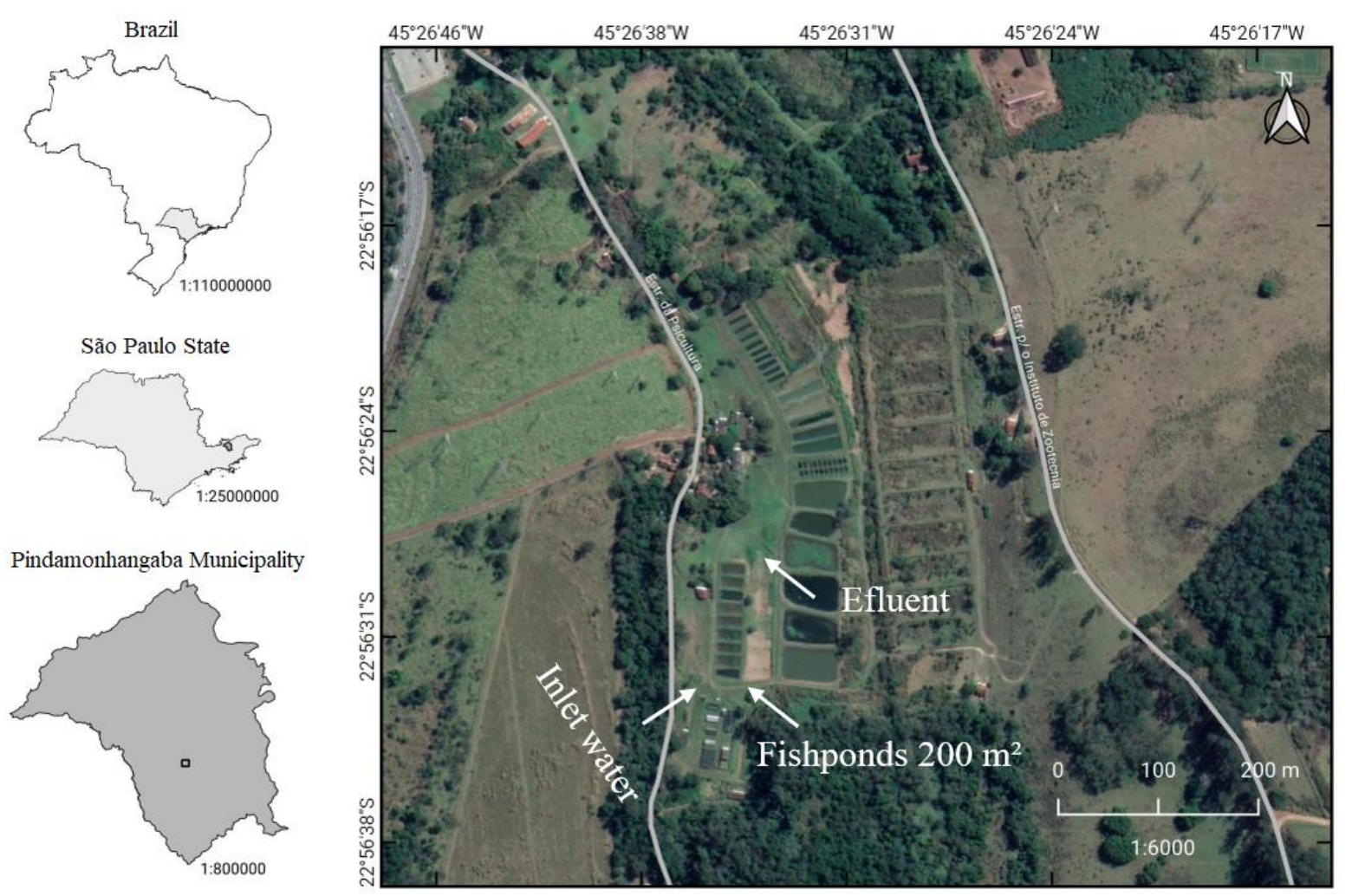

Figure 1. Study area location. The $200 \mathrm{~m}^{2}$ excavated fishponds distributed in series, the source of water supply and the place where the effluent is discharged from the fishponds are highlighted.

(Google Earth pro source - Image taken on July 23, 2019).

During the grow-out period, the extruded formulation of QUALY® fish feed containing $32-45 \%$ crude protein and $1.0-1.3 \%$ phosphorus was offered twice a day. The amount of feed offered was $1.5-3.0 \%$ of the total estimated biomass, taking into account the stage of population development (size/age) and the estimated biomass produced. To estimate the biomass produced, biometrics were performed monthly considering the analysis of a batch containing $10 \%$ of the total fish population of each pond.

\subsection{Design of artificial floating islands}

The experimental design was completely randomized with two treatments and three replications (Figure 2). The treatments were as follows: T1) Nile tilapia grow-out fishponds with artificial floating islands (AFIs) colonized by Eichhornia crassipes and T2) Nile tilapia grow-out fishponds without artificial floating islands (without AFIs).

The artificial floating islands installed in the fishponds were built with $2 \mathrm{~m}^{2}$ each, using PVC pipes and fishing nets, easy-finding and low-cost materials, occupying $10 \%$ of the fishpond area. The details of the structure and dimensions of the AFIs are described in Osti $e t$ al. (2020). According to the aforementioned authors, the floating artificial islands model is easy to install and maintain, robust enough to withstand macrophyte management, and it is not necessary to remove it for fish measurements throughout the grow-out period. The fishing nets are suited to fix the root system of macrophytes, preventing their dispersion in the fishponds. 


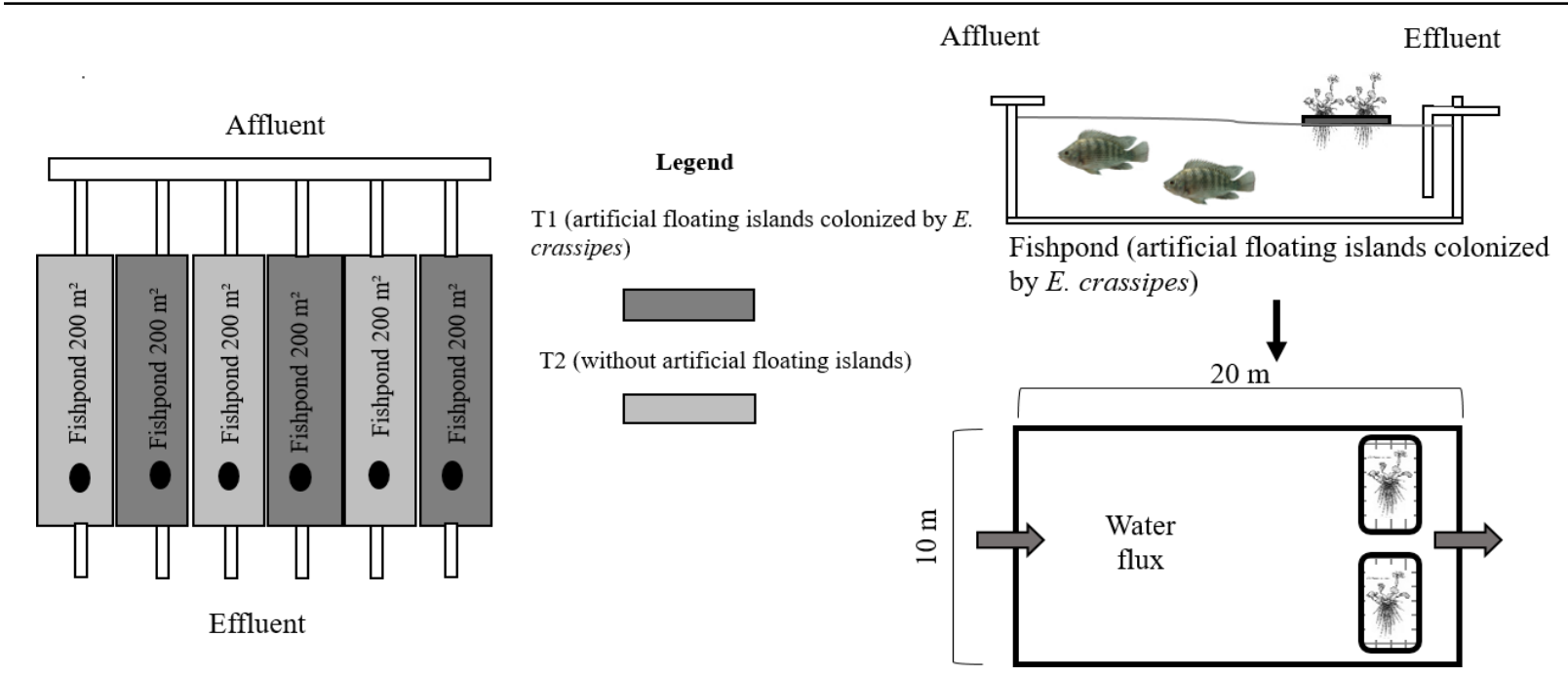

Figure 2. Schematic drawing of the Nile tilapia (O. niloticus) grow-out fishponds and the artificial floating islands colonized by Eichhornia crassipes. Adapted from Osti et al. (2020).

\subsection{Limnological variables}

Limnological variables were measured based on triplicates of water samples collected every two weeks during 133 days from December 2018 to April 2019. Sampling was carried out in the center of the fishponds between 9:00 am and 10:00 am (Figure 2).

Water temperature $\left({ }^{\circ} \mathrm{C}\right)$, dissolved oxygen $\left(\mathrm{mg} \mathrm{L}^{-1}\right)$, electrical conductivity $\left(\mu \mathrm{S} \mathrm{cm}^{-1}\right)$, turbidity (NTU), total dissolved solids $\left(\mathrm{mg} \mathrm{L}^{-1}\right)$ and $\mathrm{pH}$ were measured in situ using a Horiba U-50 multiparametric probe. The water transparency was determined through the visual disappearance of the Secchi disk (m). With the aid of sterilized bottles, water samples were collected for the analysis of total nitrogen $(\mathrm{TN})\left(\mu \mathrm{g} \mathrm{L}^{-1}\right)$ and total phosphorus $(\mathrm{TP})\left(\mu \mathrm{g} \mathrm{L}^{-1}\right)$ following the methodology described by Valderrama (1981); nitrite $\left(\mathrm{NO}_{2}^{-}-\mathrm{N}\right)\left(\mu \mathrm{g} \mathrm{L}^{-1}\right)$ and nitrate $\left(\mathrm{NO}_{3}-\mathrm{N}\right)\left(\mu \mathrm{g} \mathrm{L}^{-1}\right)$ were determined according to Giné et al. (1980). While the total ammonia nitrogen (TAN) $\left(\mu \mathrm{g} \mathrm{L}^{-1}\right)$ followed the Nessler technique described in APHA et al. (2005), the ammonia $\left(\mathrm{NH}_{3}-\mathrm{N}\right)$ and ammonium ion $\left(\mathrm{NH}_{4}{ }^{+}-\mathrm{N}\right)$ fractions were determined based on the chemical balance between nitrogen forms as a function of temperature and $\mathrm{pH}$, according to the mathematical model described by Emerson et al. (1975) and Chapra (2008). Organic nitrogen $(\mathrm{OrgN})$ was estimated by the difference between $\mathrm{TN}$ and the sum of $\mathrm{NO}_{2}^{-}-\mathrm{N}, \mathrm{NO}_{3}{ }^{-}-\mathrm{N}$ and TAN. Orthophosphate $\left(\mathrm{PO}_{4}{ }^{3-}-\mathrm{P}\right)\left(\mu \mathrm{g} \mathrm{L}^{-1}\right)$ was determined by the method described by Strickland (1960). The concentration of chlorophyll $a$ (CL $a$ ) was estimated using the method and calculation described by Marker et al. (1980) and Sartory and Grobellar (1984). The analyses were performed at the water quality laboratory of the Fisheries Institute.

\subsection{Statistical analyses}

The means of the final weight, harvest mass and apparent feed conversion rate were compared between the fishponds with and without AFIs using the t-test (Semmar, 2013). A descriptive analysis was performed for the limnological variables between the fishponds with and without AFIs structure and for the tilapia production data. To assess possible differences in water quality between the fishponds with and without AFIs, we used the Kruskal-Wallis independent non-parametric test $(\alpha=0.05)$ (Corder and Foreman, 2014).

To assess the relationship of limnological variables between treatments, especially the influence of macrophytes in the fishponds with AFIs, we used the Principal Component Analysis (PCA) through the correlation matrix between the Nile tilapia grow-out fishponds with and without artificial floating islands and limnological variables (Vicini, 2005). The limnological variables that showed the highest Pearson correlation with axes 1 and $2(r>0.5)$ were retained, whereas the variables that could cause multicollinearity were excluded 
João Alexandre Saviolo Osti et al.

(Legendre and Legendre, 2012). For the analysis, the PC-ORD 6.0 program for Windows (McCune and Mefford, 1997) was used, and the data was transformed by $[\log (\mathrm{x}+1)]$, except for $\mathrm{pH}$.

\section{RESULTS}

The final average weight, survival rate and harvest mass in the fishponds with artificial floating islands technology were $232.78 \mathrm{~g}_{\text {per animal }}^{-1}, 90 \%$ and $5,753 \mathrm{~kg} \mathrm{ha}^{-1}$, respectively. These results were similar to those observed in the fishponds without AFIs, which corresponded to $233.35 \mathrm{~g}$ per animal ${ }^{-1}, 90 \%$ and $5,788 \mathrm{~kg} \mathrm{ha}^{-1}$, respectively. The amount of feed offered throughout the grow-out period was the same for both fishponds and reached $9,743 \mathrm{~kg} \mathrm{ha}^{-1}$ (Table 1).

Table 1. Zootechnical performance data of Nile tilapia during the grow-out period in a semi-intensive production system and excavated fishponds $(\mathrm{n}=3)$ with artificial floating islands colonized by Eichhornia crassipes (AFIs) and without artificial floating islands (without AFIs). Data from Osti et al. (2020).

\begin{tabular}{lcc}
\hline Zootechnical performance & AFIs & Without AFIs \\
\hline Initial average weight $(\mathrm{g})$ & $23.97(2.8)$ & $21.3(1.3)$ \\
Final average weight $(\mathrm{g})$ & $232.78(14.2)$ & $233.35(44.35)$ \\
Harvest mass $\left(\mathrm{kg} \mathrm{ha}^{-1}\right)$ & $5,753(395)$ & $5,788(1.170)$ \\
Survival $(\%)$ & 90 & 90 \\
Apparent Feed Conversion Rate & $1.7(0.1)$ & $1.73(0.4)$ \\
\hline
\end{tabular}

In general, the results of limnological variables observed in the Nile tilapia fishponds with or without AFIs are within the ideal range for tropical fish production when compared to specialized literature (Table 2). The fishponds with AFIs had the lowest average concentrations of TN and TP $\left(409.1 \pm 68.3 \mu \mathrm{g} \mathrm{L}^{-1}\right.$ and $66.2 \pm 11.8 \mu \mathrm{g} \mathrm{L}^{-1}$, respectively), when compared to the fishponds without AFIs (449.8 $\pm 77.3 \mu \mathrm{g} \mathrm{L}^{-1}$ of TN and $84.4 \pm 14.2 \mu \mathrm{g} \mathrm{L}^{-1}$ of TP). The mean value of water transparency registered in the fishponds with AFIs $(0.47 \pm 0.1 \mathrm{~m})$ was higher than the mean value observed in the fishponds without AFIs $(0.44 \pm 0.1 \mathrm{~m})$. The mean values of conductivity, water temperature, $\mathrm{pH}$ and $\mathrm{DO}$ did not differ between the fishponds with AFIs $\left(50 \pm 10 \mu \mathrm{S} \mathrm{cm}^{-1} ; 26.9 \pm 0.9^{\circ} \mathrm{C} ; 5.9 \pm 0.3\right.$ and $5.7 \pm 0.9 \mathrm{mg} \mathrm{L}^{-1}$ and without AFIs $(0.05 \pm 0.01$ $\mu \mathrm{S} \mathrm{cm}^{-1} ; 27.3 \pm 1.2^{\circ} \mathrm{C} ; 6.1 \pm 0.2$ and $5.8 \pm 1.2 \mathrm{mg} \mathrm{L}^{-1}$ ), respectively (Table 2 ). We observed a decrease in nutrient concentrations between the fishponds with and without AFIs. Ammonia and ammonium ion concentrations were reduced by 44 and $10 \%$, respectively, while total phosphorus and orthophosphate decreased by 21.6 and $16 \%$, respectively.

The joint analysis of the data, through the Principal Component Analysis (PCA) (Table 3; Figure 3 ), evidenced in the first axis ( $\mathrm{PC} 1=50.63 \%$ of explicability) the formation of two groups ordered based on the presence or not of the AFIs technology and limnological characteristics. The first group was formed by the fishponds with AFIs and related to the highest values of water transparency (Secchi) and the lowest values of $\mathrm{pH}$, turbidity, total dissolved solids and concentrations of chlorophyll $a(\mathrm{CL} a)$, total nitrogen (TN), total ammonia nitrogen (TAN), total phosphorus (TP) and orthophosphate $\left(\mathrm{PO}_{4}{ }^{3-}-\mathrm{P}\right)$. The second group was formed by the fishponds without AFIs and related to the highest values of the variables mentioned, except for water transparency, which was lower. The second axis (PC2 $=20.05 \%$ of explicability) showed the relationship between limnological variables compared to the production period. With approximately 30 days of production, the fishponds with AFIs had the lowest concentrations of TP and $\mathrm{PO}_{4}{ }^{3-}-\mathrm{P}$, whereas for $\mathrm{CL} a, \mathrm{TN}$ and TAN, the differences were 
registered more accentuated only after 90 days of production and coincided with the plant management period. Although reduced concentrations of dissolved oxygen were observed shortly after plant management, the fish development was not compromised, since DO concentrations remained above $4 \mathrm{mg} \mathrm{L}^{-1}$, which is considered suitable for tropical fish production.

Table 2. Average concentrations, standard deviation (SD), minimum (Min) and maximum (Max) values of the limnological variables of the fishponds with and without artificial floating islands (AFIs), during the grow-out period of Nile tilapia. Average values followed by different letters $(a$ and $b)$ in the same row indicate differences of statistical significance by Kruskal-Wallis test $(p<0.05)$.

\begin{tabular}{|c|c|c|c|c|c|}
\hline \multirow{2}{*}{ Limnological variables } & \multicolumn{2}{|c|}{ Without AFIs } & \multicolumn{2}{|c|}{ AFIs } & \multirow{2}{*}{ References } \\
\hline & Average (SD) & Min-Max & Average (SD) & Min-Max & \\
\hline T. $\left({ }^{\circ} \mathrm{C}\right)$ & $27.32(1.23) \mathbf{a}$ & $25.2-29.2$ & $26.90(0.98) \mathbf{a}$ & $25.4-28.8$ & $26-30^{€}$ \\
\hline$p H$ & $6.14(0.29) \mathbf{b}$ & $5.5-6.7$ & $5.94(0.33) \mathbf{a}$ & $5.1-6.4$ & $6.0-8.5^{\S}$ \\
\hline Cond. $\left(\mu S \mathrm{~cm}^{-1}\right)$ & $55.97(16.05) \mathbf{a}$ & $24.0-96.0$ & $54.23(13.58) \mathbf{a}$ & $37.0-86.0$ & --- \\
\hline Turbidity (NTU) & $36.29(17.2) \mathbf{b}$ & $11.1-76.7$ & $27.86(17.18) \mathbf{a}$ & $7.3-79.3$ & $<100^{\beta}$ \\
\hline$D O\left(m g O_{2} L^{-1}\right)$ & $5.82(1.53) \mathbf{a}$ & $4.2-9.7$ & $5.72(1.46) \mathbf{a}$ & $3.2-8.9$ & $>5.0^{\#}$ \\
\hline$D O(\%)$ & $73.97(21.19) \mathbf{a}$ & $46.8-128.8$ & $69.01(23.32) \mathbf{a}$ & $5.7-116.0$ & $>50 \% \S$ \\
\hline$T D S\left(\mu g L^{-1}\right)$ & $36.80(10.15) \mathbf{a}$ & $14.0-65.0$ & $36,26(10.01) \mathbf{a}$ & $25.0-60.0$ & -- \\
\hline$T N\left(\mu g L^{-1}\right)$ & $449.76(80.03) \mathbf{b}$ & $293.3-609.9$ & $409.11(69.42) \mathbf{a}$ & $303.1-546.8$ & --- \\
\hline $\operatorname{TAN}\left(\mu g L^{-1}\right)$ & $434.3(74.92) \mathbf{b}$ & $300.0-506.7$ & $389.0(68.04) \mathbf{a}$ & $290.0-480.0$ & --- \\
\hline$N_{4}^{+}-N\left(\mu g L^{-1}\right)$ & $433.8(77.70) \mathbf{b}$ & $279.5-577.8$ & $388.7(68.05) \mathbf{a}$ & $279.9-479.3$ & --- \\
\hline $\mathrm{NH}_{3}-\mathrm{N}\left(\mu g L^{-1}\right)$ & $0.50(0.34) \mathbf{b}$ & $0.078-1.355$ & $0.28(0.20) \mathbf{a}$ & $0.025-0.742$ & $<70^{\beta}$ \\
\hline $\mathrm{NO}_{2}^{-}-\mathrm{N}\left(\mu g L^{-1}\right)$ & $3.53(0.59) \mathbf{a}$ & $2.3-4.6$ & $3.21(0.72) \mathbf{a}$ & $1.2-4.5$ & $<300^{\S}$ \\
\hline$N_{3}-N\left(\mu g L^{-1}\right)$ & $0.015(0.005) \mathbf{a}$ & $0.1-0.02$ & $0.014(0.005) \mathbf{a}$ & $0.01-0.02$ & --- \\
\hline$P O_{4}{ }^{3-}-P\left(\mu g L^{-1}\right)$ & $7.55(0.55) \mathbf{b}$ & $6.4-8.9$ & $6.34(0.89) \mathbf{a}$ & $4.8-8.2$ & --- \\
\hline$T P\left(\mu g L^{-1}\right)$ & $84.41(16.64) \mathbf{b}$ & $44.6-129.0$ & $66.19(13.95) \mathbf{a}$ & $33.5-103.1$ & --- \\
\hline $\operatorname{Secchi}(m)$ & $0.43(0.11) \mathbf{a}$ & $0.22-0.62$ & $0.47(0.12) \mathbf{a}$ & $0.26-0.72$ & $30-50^{\S}$ \\
\hline$C L a\left(\mu g L^{-1}\right)$ & 4.45 (1.67) b & $2.5-7.7$ & $3.01(0.44) \mathbf{a}$ & $2.5-4.1$ & --- \\
\hline
\end{tabular}

${ }^{\beta}$ El-Sayed (2019); ${ }^{\S}$ Kubitza (2003); ${ }^{\#}$ Boyd and Tucker (1998); ${ }^{€}$ Ono and Kubitza (2003).

Table 3. Pearson correlation coefficient between physical and chemical variables in the fishponds with AFIs and Without AFIs, during the growout period of Nile tilapia.

\begin{tabular}{lccc}
\hline Limnological variables & Abbreviation & Axis 1 & Axis 2 \\
\hline Dissolved oxygen $\left(\mathrm{mg} \mathrm{L}^{-1}\right)$ & DO & -0.041 & $\mathbf{- 0 . 5 2 3}$ \\
Total dissolved solids $\left(\mathrm{mg} \mathrm{L}^{-1}\right)$ & TDS & -0.450 & -0.408 \\
Secchi $(\mathrm{m})$ & Secchi & $\mathbf{- 0 . 6 8 5}$ & $\mathbf{- 0 . 5 7 7}$ \\
Chlorophyll $a\left(\mu \mathrm{g} \mathrm{L}^{-1}\right)$ & $\mathrm{CL} a$ & $\mathbf{0 . 8 3 0}$ & -0.119 \\
Total nitrogen $\left(\mu \mathrm{g} \mathrm{L}^{-1}\right)$ & $\mathrm{TN}$ & $\mathbf{0 . 8 0 6}$ & 0.278 \\
Total ammonia nitrogen $\left(\mu \mathrm{g} \mathrm{L}^{-1}\right)$ & $\mathrm{TAN}$ & $\mathbf{0 . 8 2 2}$ & 0.283 \\
Total phosphorus $\left(\mu \mathrm{g} \mathrm{L}^{-1}\right)$ & $\mathrm{TP}$ & $\mathbf{0 . 6 7 7}$ & $\mathbf{- 0 . 5 9 3}$ \\
Orthophosphate $\left(\mu \mathrm{g} \mathrm{L}^{-1}\right)$ & $\mathrm{PO}_{4}{ }^{3-}-\mathrm{P}$ & $\mathbf{0 . 6 3 5}$ & $\mathbf{- 0 . 5 8 4}$ \\
\hline
\end{tabular}

Explicability $\quad \mathbf{5 0 . 6 3 \%} \quad \mathbf{2 0 . 0 5 \%}$ 


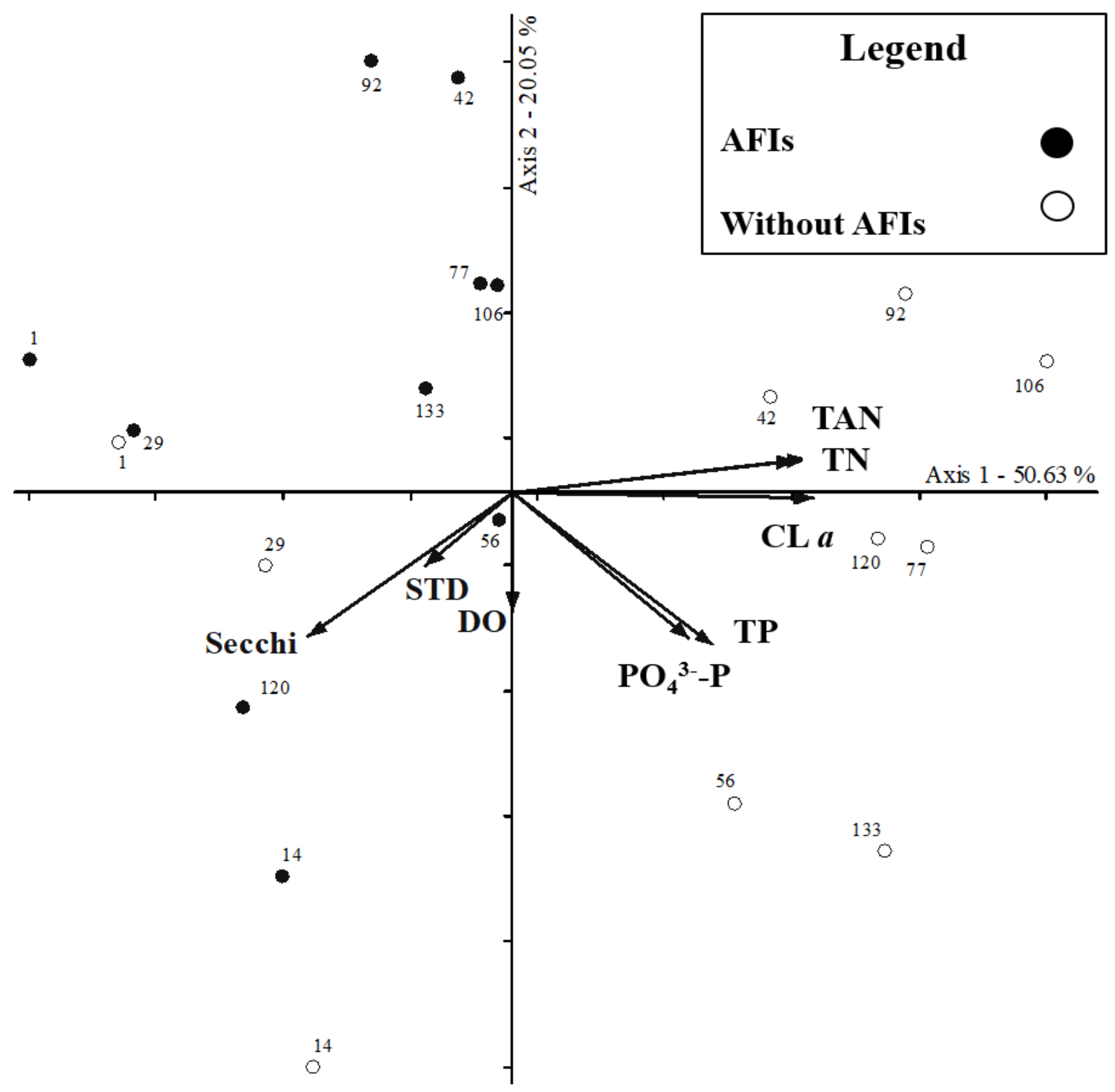

Figure 3. Principal component analysis biplot with ordination of the studied environments in relation to limnological variables in the fishponds with AFIs and Without AFIs, during the growout period of Nile tilapia.

\section{DISCUSSION}

The artificial floating island technology used in this study improved the water quality of the Nile tilapia fishponds, significantly reducing concentrations of TN, TAN, $\mathrm{NH}^{+}{ }_{4}-\mathrm{N}, \mathrm{NH}_{3}-\mathrm{N}$, $\mathrm{TP}, \mathrm{PO}_{4}{ }^{3-}-\mathrm{P}$ and chlorophyll $a$, without affecting zootechnical performance of fish that achieved a yield considered satisfactory for the species (Pezzato et al., 2004; Luz and Portella, 2005).

The AFIs with macrophytes and their associated periphyton exert changes in the water quality of fishponds (Crispim et al., 2009, Sipaúba-Tavares et al., 2015; Chang et al., 2017), as shown in Figure 3. These alterations occur directly and indirectly. The direct change is the assimilation of nutrients that are present in the water body, which are used in the growth metabolism of macrophytes and their associated periphyton. The assimilation of nutrients by autotrophic organisms, such as macrophytes and algae, in general, is associated with the activity of chloroplast through reactions that are activated by light, as well as the balance of $\mathrm{CO}_{2} / \mathrm{HCO}_{3}{ }^{-}$ $/ \mathrm{CO}_{3}{ }^{2-}$, which influences the $\mathrm{pH}$, associated with photosynthesis/respiration processes (HenrySilva and Camargo, 2008; Rodrigues et al., 2010). Aquatic macrophytes with large biomass 
and fast growth, such as E. crassipes, probably require more nutrients when compared to emerging and/or free-floating macrophytes with less biomass and, therefore, efficiently remove nutrients from the water column (Henares and Camargo 2014; Osti et al., 2018b). Cumulatively, macrophytes and their periphyton remove nutrients and pollutants present in the water by various mechanisms, such as assimilation, development of biofilms, release of extracellular enzyme, sedimentation and trapping of contaminants, as well as increase flocculation of suspended matter (Sipaúba-Tavares et al., 2015; Yeh et al., 2015; Nafath-Ul-Arab et al., 2021). Chang et al. (2017) suggests that the ability of macrophyte roots to secrete oxygen, forming anaerobic/anoxic/oxi micro-areas, promote mechanisms that are similar to the process of treating sanitary effluents by activated sludge with removal of nutrients, known as the Phoredox system or $\mathrm{A}^{2} / \mathrm{O}$ (anaerobic/ anoxic/oxi). The indirect action of macrophytes in the water, on the other hand, occurs through competition between macrophytes and phytoplankton, either for nutrients or for photosynthetic radiation (Abdel-Tawwab, 2006). In fishponds, phytoplankton are of fundamental importance for maintaining water quality, since they can significantly alter the concentration of nutrients, gases and water $\mathrm{pH}$ during photosynthesis/respiration processes (Boyd and Tucker, 1998; Rodrigues et al., 2010), and when in bloom formation, they can lead to a decrease in productivity performance and fish mortality with a consequent decrease in the profitability of the activity (Mercante et al., 2007; Boyd, 2006).

The phosphate ion, an assimilable form by autotrophic organisms, represented less than $10 \%$ of the total phosphorus in the fishpond water. However, the ammonium ion represented more than $90 \%$ of the total nitrogen present in the water, followed by the organic fraction with less than 5\%, as shown in Table 4. Despite the high concentration of nitrogen in the ammoniacal form, the concentration of ammonium gas remained at levels considered safe in both treatments due to the neutral/slightly acidic $\mathrm{pH}$, which led to the predominance of the ammonium ion in the fishpond water (Mercante et al., 2018).

Table 4. Nitrogen fractions present in the fishponds with and without artificial floating islands (AFIs), during the grow-out period of Nile tilapia.

\begin{tabular}{cccccc}
\hline & $\mathrm{OrgN}(\%)$ & $\mathrm{NH}_{4}{ }^{-}-\mathrm{N}(\%)$ & $\mathrm{NH}_{3}-\mathrm{N}(\%)$ & $\mathrm{NO}_{2}{ }^{-} \mathrm{N}(\%)$ & $\mathrm{NO}_{3}{ }^{-}-\mathrm{N}(\%)$ \\
\hline AFIs & 4,16 & 94,96 & 0,07 & 0,81 & 0 \\
Without AFIs & 2,64 & 96,45 & 0,11 & 0,80 & 0
\end{tabular}

Reduced forms of nitrogen, that is, the organic and ammoniacal forms, consume oxygen through nitrification in the oxidation process of the ammonium ion $\left(\mathrm{NH}_{4}{ }^{+}-\mathrm{N}\right)$. The two main genera of bacteria that participate in this process are Nitrosomonas, that oxidize $\mathrm{NH}_{4}{ }^{+}-\mathrm{N}$ to nitrite $\left(\mathrm{NO}_{2}{ }^{-}-\mathrm{N}\right)$, and Nitrobacter, that oxidize $\mathrm{NO}_{2}{ }^{-}-\mathrm{N}$ to nitrate $\left(\mathrm{NO}_{3}{ }^{-}-\mathrm{N}\right)$ (Vasconcelos et al., 2020). During this process, each $1 \mathrm{~g}$ of nitrogen in ammoniacal form consumes $4.57 \mathrm{~g}$ of dissolved oxygen (Esteves, 2011). Thus, the average concentration of ammonium ion found in the fishponds without AFIs $\left(433.8 \mu \mathrm{g} \mathrm{L}^{-1}\right)$ represents a theoretical oxygen demand of $1.98 \mathrm{mg}$ $\mathrm{L}^{-1}$ for its oxidation to nitrate, $12 \%$ higher than what was registered in the fishponds with AFIs (1.77 $\left.\mathrm{mg} \mathrm{L}^{-1}\right)$. The dissolved oxygen concentration observed in both fishponds was close to the lower limit considered suitable for fish production (Boyd and Tucker, 1998). Thus, the concentrations of total ammonia nitrogen exerted an extra pressure on the DO concentration, which is an essential gas for the success of the production system.

In the fishponds with AFIs, the reduction in TP concentration was lower than that of TN (Table 2). This result can be explained by the fact that the preferred form of nutrient assimilation by macrophytes is the inorganic fraction (Chang et al., 2017), and phosphorus limitation may have occurred for the full development of the macrophyte, given that only $10 \%$ of the total phosphorus was in the inorganic form. The high concentrations of TP observed in the fishponds with AFIs (103.1 $\left.\mathrm{g} \mathrm{L} \mathrm{L}^{-1}\right)$ may have led to phosphorus saturation in the plant tissue. According 
to Henares and Camargo (2014), this is due to the species saturation point that is $0.26 \mathrm{mg} \mathrm{L}^{-1}$ of $\mathrm{N}$ and $77 \mu \mathrm{g} \mathrm{L}^{-1}$ of P. A similar result was recorded by Gaballah et al. (2021), who evaluated the efficiency in the removal of nutrients with AFIs colonized by E. crassipes in a pilot study, and verified a decline in the removal of $\mathrm{P}$ after 5 days of experiment and related these values to phosphorus saturation. The N:P ratio should also be considered when studying the removal of nutrients by $E$. crassipes, since this species accumulates $\mathrm{N}$ more quickly in its tissue than $\mathrm{P}$, and phosphorus assimilation is affected by the N:P ratio (Jayaweera and Kasturiarachchi, 2004). Sato and Kondo (1981), in an experimental trial, found out that concentrations of $50 \mathrm{mg} \mathrm{L}^{-1}$ of nitrogen and $13.8 \mathrm{mg} \mathrm{L}^{-1}$ of inorganic phosphorus are needed for the ideal development of $E$. crassipes, which results in a DIN:DIP ratio of 8:1. Reddy and Tucker (1983) suggest that to achieve the maximum biomass yields of $E$. crassipes, the optimum N:P ratio in the water must be between 5:1 and 11:1 of DIN:DIP ratio. In the fishponds with AFIs, the average N:P ratio was 14:1, whereas the average DIN:DIP ratio was 134:1 (Figure 4).
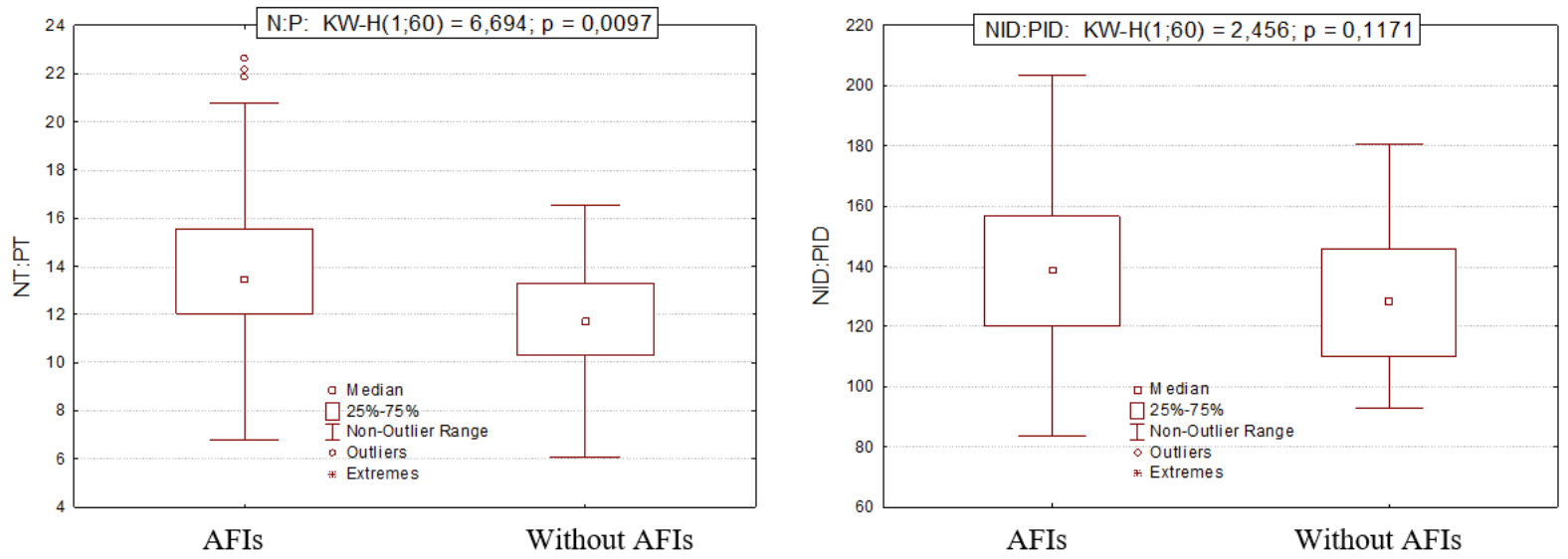

Figure 4. Box-plot of N:P and NID:PID ratios in the fishponds with and without artificial floating islands (AFIs), during the grow-out period of Nile tilapia. Box plot presents the median (squares), interquartile distance (box), minimum and maximum (whiskers), outlines (circles) and extremes (asterisks).

The residence time of water in fishponds is a parameter that must be controlled to improve the efficiency of the AFIs (Osti et al., 2020). Sipaúba-Tavares et al. (2002) recommend hydraulic retention time between 1 and 4 days for a more efficient removal of nutrients and other pollutants by aquatic plants. However, Gentelini et al. (2008) and Osti et al. (2018b) observed phosphorus removal efficiency of 41 and $38 \%$ with hydraulic retention times of 12 and 13 hours, respectively. In this experiment, the total phosphorus removal efficiency by the AFIs was $21.6 \%$ with a hydraulic retention time of 26 hours, which may have limited the AFIs removal efficiency. The proper water quality, even in the fishponds without AFIs, may be explained by the low hydraulic retention time and the quality of the water that supplies the production system.

The coverage rate of the islands is an extremely important factor, since AFIs can restrict the diffusion of oxygen from air to water (Chang et al., 2017). Boyd and Tucker (1998) suggest that macrophyte coverage between $10-20 \%$ in fishponds is generally harmful. Abdel-Tawwab (2006) observed that coverages above $50 \%$ of the surface area of fishponds, colonized by the macrophyte Azolla pinatta, significantly reduced the concentrations of oxygen, $\mathrm{pH}$, conductivity, phosphate, nitrate, phytoplankton, zooplankton and fish productivity. The author recommends that macrophyte coverage should not exceed $25 \%$ of the surface area of fishponds to obtain a balanced ecosystem. Saeed and Al-Nagaawy (2013), when evaluating the effect of E. crassipes with a coverage of $10 \%$ in tilapia fishponds, observed a slight effect on water 
quality, a decrease in the nutrient load and phytoplankton biomass, which had no significant effect on fish production. Chang et al. (2017) point to an ideal coverage of approximately $20 \%$, as long as the aerobic condition is maintained without artificial aeration. In this study, the presence of AFIs, at a coverage rate of $10 \%$ of the fishponds' surface, improved the water quality, reducing the values of $\mathrm{pH}$ and turbidity, as well as the concentrations of TN; TAN; TP; $\mathrm{PO}_{4}{ }^{3-}-\mathrm{P}$ and $\mathrm{Cl} a$ (Table 2), without affecting fish productivity.

\section{CONCLUSIONS}

The artificial floating islands (AFIs), colonized by Eichhornia crassipes and covering $10 \%$ of the fishponds area, reduced the concentrations of nutrients and chlorophyll $a$ without affecting the zootechnical performance of Nile tilapia. After 30 days of colonization with $E$. crassipes, the reduction of inorganic and organic forms of nitrogen and phosphorus were evidenced. The decrease in $\mathrm{pH}$, water transparency, chlorophyll $a$ and turbidity occurred after 90 days of colonization. Artificial floating islands technology should be encouraged for smalland medium-sized farmers as a tool to improve water quality in fishponds. However, new AFIs coverage rates must be evaluated, as well as the control of hydraulic retention rates, to promote meaningful improvements in water quality without impairing fish production.

\section{ACKNOWLEDGEMENTS}

This study was funded by the São Paulo Research Foundation - FAPESP (Process no. 2018/12664-4). We thank Luiz Cláudio dos Santos Evangelista and Vanderson Natale Dias, for their assistance in the field and laboratory analysis.

\section{ETHICS COMMITTEE}

All procedures used during this study followed the ethical procedures in animal experimentation adopted by "Colégio Brasileiro de Experimentação Animal" (COBEA) and were approved by the Ethics Committee of Animal Experimentation of the Fisheries Institute (CEEAIP) (Protocol No. 08/2018).

\section{REFERENCES}

ABDEL-TAWWAB, M. Effect of Free-Floating Macrophyte Azolla pinnataon Water PhysicoChemistry, Primary Productivity, and the Production of Nile Tilapia, Oreochromis niloticus L., and Common Carp, Cyprinus carpio L., in Fertilized Earthen Ponds. Journal of Applied Aquaculture, v. 18, n. 1, p. 21-41, 2006. https://doi.org/10.1300/J028v18n01_02

AFZAL, M.; ARSLAN, M.; MÜLLER, J. A.; SHABIR, G.; ISLAM, E.; TAHSEEN, R.; MUHAMMAD, A.; HASHMAT, A. J.; IQBAL, S.; KHAN, Q. M. Floating treatment wetlands as a suitable option for large-scale wastewater treatment. Nature Sustainability, v. 2, p. 863-871, 2019. https://doi.org/10.1038/s41893-019-0350-y

APHA; AWWA; WEF. Standard Methods for the Examination of Water and Wastewater. 21. ed. Washington, 2005.

ASSOCIAÇÃO BRASILEIRA DA PISCICULTURA. Peixe.Br: anuário brasileiro da piscicultura. São Paulo, 2020. Available at: https://www.peixebr.com.br/lancamentoanuario-peixe-br-de-piscicultura-piscicultura-2020/. Access: May 2020. 
BOYD, C. E.; TUCKER, C. S. Pond aquaculture water quality management. Springer Science \& Business Media, 1998. 700p.

BOYD, C. E. Phytoplankton a crucial component of aquaculture pond ecosystems. Global Aquaculture Advocate, p. 1-4, 2016.

CHANG, Y.; CUI, H.; HUANG, M.; HE, Y. Artificial floating islands for water quality improvement. Environmental Reviews, v. 25, n. 3, p. 350-357, 2017. https://doi.org/10.1139/er-2016-0038

CHAPRA, S.C. Surface water-quality modelling. Illinois: Waveland Press, 2008. 844p.

CHATVIJITKUL, S.; BOYD, C. E.; DAVIS, D. A.; McNEVIN, A. A. Pollution potential indicators for feed-based fish and shrimp culture. Aquaculture, v. 477, p. 43-49, 2017. https://doi.org/10.1016/j.aquaculture.2017.04.034

CORDER, G. W.; FOREMAN, D. I. Nonparametric statistics: A step-by-step approach. New York: John Wiley \& Sons, 2014.

CRISPIM, M. C.; VIEIRA, A. C. B.; COELHO, S. F. M.; MEDEIROS, A. M. A. Nutrient uptake efficiency by macrophyte and biofilm: practical strategies for small-scale fish farming. Acta limnologica brasiliensia, v. 21, n. 4, p. 387-391, 2009.

CYRINO, J. E. P.; BICUDO, Á. J. D. A.; SADO, R. Y.; BORGHESI, R.; DAIRIK, J. K. A piscicultura e o ambiente: o uso de alimentos ambientalmente corretos em piscicultura. Revista Brasileira de Zootecnia, v. 39, p. 68-87, 2010. https://doi.org/10.1590/S151635982010001300009

DAVID, F. S.; PROENÇA, D. C.; VALENTI, W. C. Phosphorus budget in integrated multitrophic aquaculture systems with Nile tilapia, Oreochromis niloticus, and Amazon River prawn, Macrobrachium amazonicum. Journal of World Aquaculture Society, v. 48, p. 402-414, 2017a. https://doi.org/10.1111/jwas.12404

DAVID, F. S.; PROENÇA, D. C.; VALENTI, W. C. Nitrogen budget in integrated aquaculture systems with Nile tilapia and Amazon River prawn. Aquaculture International, v. 25, p. 1733-1746, 2017b. https://doi.org/10.1007/s10499-017-0145-y

EL-SAYED, A.-F. M. Tilapia culture. Academic Press, 2019.

EMERSON, K.; RUSSO, R. C.; LUND, R. E.; THURSTON, R. V. Aqueous ammonia equilibrium calculations: effect of $\mathrm{pH}$ and temperature. Journal of the Fisheries Research Board of Canada. v. 32, n. 12, p. 2379-2383, 1975.

ESTEVES, F. A. Fundamentos de limnologia. 3. ed. Rio de Janeiro: Interciência, 2011. 826p.

FAO. The State of World Fisheries and Aquaculture - Meeting the sustainable development goals. Rome, 2018. Available at: http://www.fao.org/3/i9540en/i9540en.pdf. Access: 28 October 2019.

GABALLAH, M. S.; ISMAIL, K.; ABOAGYE, D.; ISMAIL, M. M.; SOBHI, M.; STEFANAKIS, A. I. Effect of design and operational parameters on nutrients and heavy metal removal in pilot floating treatment wetlands with Eichhornia Crassipes treating polluted lake water. Environmental Science and Pollution Research, p. 1-15, 2021. https://doi.org/10.1007/s11356-021-12442-7 
GENTELINI, A. L.; GOMES, S. D.; FEIDEN, A.; ZENATTI, D.; SAMPAIO, S. C.; COLDEBELLA, A. Produção de biomassa das macrófitas aquáticas Eichhornia crassipes (aguapé) e Egeria densa (egeria) em sistema de tratamento de efluente de piscicultura orgânica. Semina. Ciências Agrárias, v. 29, n. 2, p. 441-448, 2008.

GINÉ, H.; BERGAMIN, H.; ZAGATTO, E.A.G.; REIS, B.F. Simultaneous determination of nitrate and nitrite by flow injection analysis. Analytica Chimica Acta, v. 114, p. 191197, 1980. https://doi.org/10.1016/S0003-2670(01)84290-2

GUPTA, V.; COURTEMANCHE, J.; GUNN, J.; MYKYTCZUK, N. Shallow floating treatment wetland capable of sulfate reduction in acid mine drainage impacted waters in a northern climate. Journal of Environmental Management, v. 263, 110351, 2020. https://doi.org/10.1016/j.jenvman.2020.110351

HEADLEY, T.; TANNER, C. C.; COUNCIL, A. R. Application of floating wetlands for enhanced for stormwater treatment: a review. Auckland: Auckland Regional Council, 2008.

HENARES, M. N. P.; CAMARGO, A. F. M. Treatment efficiency of effluent prawn culture by wetland with floating aquatic macrophytes arranged in series. Brazilian Journal of Biology, v. 74, p. 906-912, 2014. http://dx.doi.org/10.1590/1519-6984.10413

HENRY-SILVA, G. G., CAMARGO, A. F. M. Tratamento de efluentes de carcinicultura por macrófitas aquáticas flutuantes. Revista Brasileira de Zootecnia, v. 37, p. 181-188, 2008. http://dx.doi.org/10.1590/S1516-35982008000200002

HUBBARD, R. K.; GASCHO, G. J.; NEWTON, G. L. Use of floating vegetation to remove nutrients from swine lagoon wastewater. Transactions of ASABE, v. 47, n.6, p. 1963 1972, 2004. http://dx.doi.org/10.13031/2013.17809

JAYAWEERA, M. W.; KASTURIARACHCHI, J. C. Removal of nitrogen and phosphorus from industrial wastewaters by phytoremediation using water hyacinth (Eichhornia crassipes (Mart.) Solms). Water Science and Technology, v. 50, n. 6, p. 217-225, 2004. https://doi.org/10.2166/wst.2004.0379

KUBITZA, F. Qualidade da água no cultivo de peixes e camarões. Jundiaí: Aqua Imagem, 2003. 229p.

KURASHOV, E.; KRYLOVA, J.; PROTOPOPOVA, E. The Use of Allelochemicals of Aquatic Macrophytes to Suppress the Development of Cyanobacterial "Blooms". In Plankton Communities. IntechOpen, 2021. http://dx.doi.org/10.5772/intechopen.95609

LEGENDRE, P.; LEGENDRE, L.F. Numerical ecology. Hoboken: Elsevier, 2012.

LUZ, R. K.; PORTELLA, M. C. Tolerance to the air exposition test of Hoplias lacerdae larvae and juvenile during its initial development. Brazilian Archives Biology Technology, v.48, p. 567-573, 2005. https://doi.org/10.1590/S1516-89132005000500009

LYNCH, J.; FOX, L. J.; OWEN, J. S.; SAMPLE, D. J. Evaluation of commercial floating treatment wetland technologies for nutrient remediation of stormwater. Ecological Engineers, v. 75, p. 61-69, 2015. https://doi.org/10.1016/j.ecoleng.2014.11.001

MARKER, A. F. H.; NUSCH, H.; RAI, H.; RIEMANN, B. The measurement of photosynthetic pigments in freshwaters and standardization of methods: conclusion and recommendations. Archiv für Hydrobiologia, v. 14, p. 91-106, 1980. 
McCUNE, B.; MEFFORD, J. J. PC-ord. Multivariate analysis of ecological data, version 3.0. Oregon: MjM Software Design, 1997. 47p.

MERCANTE, C. T. J.; MARTINS, K. Y.; CARMO, C. F.; OSTI, J. S.; SCHIMIDT, C. M; TUCCI, A. Qualidade da água em viveiro de Tilápia do Nilo (Oreochromis niloticus): caracterização diurna de variáveis físicas, químicas e biológicas, São Paulo, Brasil. Bioikos, v. 21, p. 79-88, 2007.

MERCANTE, C. T.; DAVID, G. S.; RODRIGUES, C. J.; DO CARMO, C. F.; DA SILVA, R. J. Potential toxic effect of ammonia in reservoirs with Tilapia culture in cages. International Journal of Fisheries and Aquatic Studies, v. 6, n. 5, 256-261, 2018.

MERCANTE, C. T. J.; OSTI, J. A. S.; MORAES, M. D. A. B.; DO CARMO, C. F. A importância do fósforo na produção ambientalmente sustentável em aquicultura continental. In: CORDEIRO, C. A. M. (org.). Ciência e tecnologia do pescado: uma análise pluralista. Guarujá: Científica Digital, 2020.375 . http://dx.doi.org/10.37885/201101972

MORAES, M. A. B.; CARMO, C. F.; TABATA, Y. A.; VAZ-DOS-SANTOS, A. M.; MERCANTE, C. T. J. Environmental indicators in effluent assessment of rainbow trout (Oncorhynchus mykiss) reared in raceway system through phosphorus and nitrogen. Brazilian Journal of Biology, v. 76, p. 1021-1028, 2016. http://dx.doi.org/10.1590/1519-6984.07315

NAFATH-UL-ARAB, A. A.; BALKHI, M. H.; BAZAZ, A. I.; YOUSUF, Z.; HAFEEZ, Z.; KHAN, B. S. et al. Floating wetlands-a new Sustainable Lake Cleaning Technology. Asian Journal of Fisheries Research, v. 1, n. 1, p. 01-05, 2021.

ONO, E. A.; KUBITZA, F. Cultivo de peixes em tanques-rede. 3. ed. Jundiaí. 2003. 112 p.

OSTI, J. A. S.; MORAES, M. A. B.; CARMO, C. F.; MERCANTE, C. T. J. Nitrogen and phosphorus flux from the production of Nile tilapia through the application of environmental indicators. Brazilian Journal of Biology, v. 78, p. 25-31, 2018a. http://dx.doi.org/10.1590/1519-6984.02116

OSTI, J. A. S.; HENARES, M. P.; CAMARGO, A. F. M. A comparison between free-floating and emergent aquatic macrophytes in constructed wetlands for the treatment of a fish pond effluent. Aquaculture Research, v. 49, p. 3468-3476, 2018b. https://doi.org/10.1111/are.13813

OSTI, J. A. S.; DO CARMO, C. F.; CERQUEIRA, M. A. S.; GIAMAS, M. T. D.; PEIXOTO, A. C.; VAZ-DOS-SANTOS, A. M. et al. Nitrogen and phosphorus removal from fish farming effluents using artificial floating islands colonized by Eichhornia crassipes. $\begin{array}{llllll}\text { Aquaculture } & \text { Reports, } & \text { v. } & 17, & \text { n. } & 100324,\end{array}$ https://doi.org/10.1016/j.aqrep.2020.100324

PARK, H. K.; BYEON, M. S.; CHOI, M. J.; YUN, S. H.; JEON, N. H.; YOU, K. A. et al. Water quality improvement through the interaction of biotic and abiotic variables within the rhizospheric zone of an artificial floating vegetation island. Journal of Freshwater Ecology, v. 33, n. 1, p. 57-72, 2018. https://doi.org/10.1080/02705060.2017.1422559 
PEZZATO, M. M.; CAMARGO, A. F. M. Photosynthetic rate of the aquatic macrophyte Egeria densa Planch. (Hydrocharitaceae) in two rivers from the Itanhaém River Basin in São Paulo State, Brazil. Brazilian Archives of Biology and Technology, v. 47, n. 1, p. 153162, 2004. https://doi.org/10.1590/S1516-89132004000100021

REDDY, K. R.; TUCKER, J. C. Productivity and nutrient uptake of water hyacinth, Eichhornia crassipes I. Effect of nitrogen source. Economic botany, v. 37, n. 2, p. 237-247, 1983. https://doi.org/10.1007/BF02858790

RODRIGUES, C. J.; MERCANTE, C. T. J.; CARMO, C. F. D.; TUCCI, A.; OSTI, J. A. S.; GENARO, A. C. D. Diurnal dynamic of inorganic carbon and oxygen dissolved in a Nile tilapia (Oreochromis niloticus Linnaeus, 1758) fishpond, São Paulo, Brasil. Acta

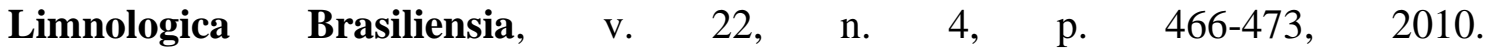
http://dx.doi.org/10.4322/actalb.2011.010

SAEED, S. M.; AL-NAGAAWY, A. M. Impact of water Hyacinth (Eichhornia Crassipes) on physico-chemical properties of water, phytoplankton biomass and Nile tilapia production in earthen ponds. Journal of the Arabian Aquaculture Society, v. 8, p. 249-262, 2013.

SARTORY, D. P.; GROBELLAR, J. U. Extraction of chlorophyll $a$ from freshwater phytoplankton for spectrophotometric analysis. Hydrobiologia, v. 114, p. 177-187, 1984. https://doi.org/10.1007/BF00031869

SATO, H; KONDO, T. Biomass production of water hyacinth and its ability to remove inorganic minerals from water: I. Effect of the concentration of culture solution on the rates of plant growth and nutrient uptake. Japanese Journal of Ecology, v. 31, n. 3, p. 257-267, 1981.

SEMMAR, N. Native Statistics for Natural Sciences. New York: Nova Science Publishers, 2013.

SIPAÚBA-TAVARES, L. H.; FAVERO, E. G. P.; BRAGA, FM de S. Utilization of macrophyte biofilter in effluent from aquaculture: I. Floating plant. Brazilian journal of biology, v. 62, n. 4a, p. 713-723, 2002.

SIPAÚBA-TAVARES, L. H.; MILLAN, R. N.; PENARIOL, I. C. Effects of biological treatments on water quality in neotropical fishponds. Limnetica, v. 34, p. 321-332, 2015. http://dx.doi.org/10.23818/limn.34.25

SPANGLER, J. T.; SAMPLE, D. J.; FOX, L. J.; OWEN JR., J. S.; WHITE, S. A. Floating treatment wetland aided nutrient removal from agricultural runoff using two wetland

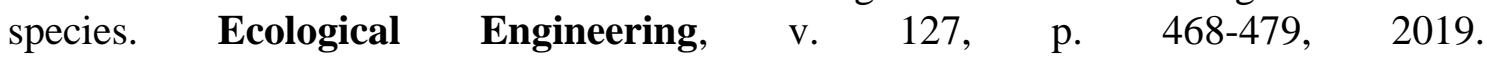
https://doi.org/10.1016/j.ecoleng.2018.12.017

STRICKLAND, J. D. H. A manual of seawater analysis. Bulletin Fisheries Research Board of Canada, v. 125, p. 1-185, 1960.

VALDERRAMA, J. C. The simultaneous analysis of total nitrogen and phosphorus in natural water. Marine Chemistry, v. 10, p. 109-122, 1981. http://dx.doi.org/10.1016/03044203(81)90027-x

VASCONCELOS, V. M.; DE MORAIS, E. R. C.; FAUSTINO, S. J. B.; HERNANDEZ, M. C. R.; GAUDÊNCIO, H. R. D. S. C.; DE MELO, R. R. et al. Floating aquatic macrophytes for the treatment of aquaculture effluents. Environmental Science and Pollution Research, p. 1-8, 2020. https://doi.org/10.1007/s11356-020-11308-8 
VICINI, L. Análise multivariada da teoria à prática. 2005. 215 f. Monografia (especialização) - Universidade Federal de Santa Maria, Santa Maria, 2005.

YEH, N.; YEH, P.; CHANG, Y-H. Artificial floating islands for environmental improvement. Renewable and Sustainable Energy Reviews, v. 47, p. 616-622, 2015. https://doi.org/10.1016/j.rser.2015.03.090 


\begin{tabular}{|} 
Ambiente \& Água - An Interdisciplinary Journal of Applied Science \\
ISSN 1980-993X - doi:10.4136/1980-993X \\
www.ambi-agua.net \\
E-mail: ambi.agua@gmail.com
\end{tabular}

\title{
Spatial variability of soil erodibility in pastures and forest areas in the municipality of Porto Velho, Rondônia
}

\author{
ARTICLES doi:10.4136/ambi-agua.2750
}

Received: 12 May 2021; Accepted: 10 Nov. 2021

\begin{abstract}
Lucivânia Izidoro da Silva1 ${ }^{1 D}$; Milton César Costa Campos $^{2}{ }^{D}$; Wildson Benedito Mendes Brito ${ }^{3 *}$; José Maurício da Cunha ${ }^{4}$; Alan Ferreira Leite de $\operatorname{Lima}^{3}$; Luís Antônio Coutrim dos Santos ${ }^{5(D ;}$; Abdul Luís Hassane ${ }^{6}$
\end{abstract}

${ }^{1}$ Programa de Pós-Graduação em Agronomia Tropical. Universidade Federal do Amazonas (UFAM), Avenida General Rodrigo Otavio Jordao Ramos, n 1200, CEP: 69067-005, Manaus, AM, Brazil.

E-mail: lucy-vany@hotmail.com

${ }^{2}$ Instituto de Educação, Agricultura e Ambiente. Universidade Federal do Amazonas (UFAM), Rua 29 de Agosto, n 786, CEP: 69077-000, Manaus, AM, Brazil.

E-mail: mcesarsolos@gmail.com

${ }^{3}$ Faculdade de Ciências Agrárias. Universidade Federal do Amazonas (UFAM), Avenida General Rodrigo Otavio Jordao Ramos, $\mathrm{n}^{\circ}$ 1200, CEP: 69067-005, Manaus, AM, Brazil.

E-mail: ala_leite@hotmail.com

${ }^{4}$ Instituto de Educação, Agricultura e Ambiente. Universidade Federal do Amazonas (UFAM), Rua 29 de Agosto, ${ }^{\circ}$ 786, CEP: 69077-000, Manaus, AM, Brazil.

E-mail: maujmc@gmail.com

${ }^{5}$ Centro De Estudos Superiores De Itacoatiara. Universidade do Estado do Amazonas (UEA), Avenida Mário Andreazza, nº 2960, CEP: 69101-603, Itacoatiara, AM, Brazil.

E-mail: lacsantos@uea.edu.br

6Programa de Pós-Graduação em Ciências Ambientais, Doutorando em Geografia na Universidade Federal Rio Grande de Sul. Faculdade de Ciências e Tecnologia. Universidade Zambeze (UniZambeze), Avenida Alfredo Lawley, CP 369, Beira, Mozambique. E-mail: assaneluis@gmail.com

*Corresponding author. E-mail: wild.brito@gmail.com

\begin{abstract}
"Erodibility" is a characteristic of the soil that represents the susceptibility with which its particles from the most superficial layer are taken and transported to lower places by erosive agents, causing environmental and economic damages. This work estimated soil erodibility in pastures and forest areas in the municipality of Porto Velho-Rondônia. In the field, three areas with different types of vegetation were selected, one with brachiaria, another with mombaça grass, and a third in native forest. In areas with pastures, a sampling mesh of equal sizes was outlined $(90 \mathrm{~m} \times 60 \mathrm{~m})$, and in the forested area an approximate sampling mesh $(90 \mathrm{~m} \times 50 \mathrm{~m})$, with a regular spacing of $10 \mathrm{~m}$ between the samples points for both areas. The sampling was done at the crossing points of the mesh at a depth of 0.0-0.2 m, composing 70 sample points in the areas with pastures and 60 sample points in the forest area, totaling 200 samples. Then, laboratory analyzes were carried out to determine the texture followed by the fractionation of the sand, and the organic carbon followed by the estimate of the organic matter of the soil. The erodibility factors were calculated using indirect prediction models, and then, univariate, geostatistical and multivariate techniques were applied. The pastures' environments differed from the forest environment. However, the mombaça grass area functions as an intermediate environment between the forest and the brachiaria, being closer to the forest environment.
\end{abstract}


Keywords: erodibility, factors, kriging, principal components.

\section{Variabilidade espacial da erodibilidade do solo em áreas de pastagens e floresta no município de Porto Velho, Rondônia}

\section{RESUMO}

A erodibilidade é uma característica do solo que representa a susceptibilidade com que suas partículas da camada mais superficial são levadas e transportadas para locais mais baixos por agentes erosivos, causando danos ambientais e econômicos. O objetivo deste trabalho foi estimar a erodibilidade do solo em áreas de pastagens e florestas no município de Porto VelhoRondônia. Em campo, foram selecionadas três áreas com diferentes tipos de vegetação, uma com braquiária, outra com capim mombaça e uma terceira em floresta nativa. Nas áreas com pastagens, foi delineada uma malha amostral de tamanhos iguais $(90 \mathrm{~m} \mathrm{x} 60 \mathrm{~m})$, e na área de floresta uma malha amostral aproximada $(90 \mathrm{~m}$ x $50 \mathrm{~m})$, com espaçamento regular de $10 \mathrm{~m}$ entre os pontos amostrais para ambas as áreas. A amostragem foi realizada nos pontos de cruzamento da malha na profundidade de $0,0-0,2 \mathrm{~m}$, compondo 70 pontos amostrais nas áreas com pastagens e 60 pontos amostrais na área de floresta, totalizando 200 amostras. Em seguida, foram realizadas análises laboratoriais para determinação da textura seguida do fracionamento da areia, e do carbono orgânico seguida da estimativa da matéria orgânica do solo. Os fatores de erodibilidade foram calculados por meio de modelos de predição indireta e, em seguida, foram aplicadas técnicas univariadas, geoestatísticas e multivariadas. Os ambientes de pastagem diferiram do ambiente de floresta. No entanto, a área de capim mombaça funciona como um ambiente intermediário entre a floresta e a braquiária, estando mais próxima do ambiente de floresta.

Palavras-chave: componentes principais, fatores erodibilidade, krigagem.

\section{INTRODUCTION}

Soil erosion is a process of detachment and accelerated drag of soil particles caused by water (water erosion) or wind (wind erosion) (Demarchi et al., 2019). Erosion can be classified into: Geological or Natural erosion, which comes from natural phenomena that act continuously in the earth's crust for the benefit of the formation of the soil itself, being recognizable only over long periods of activity; and Accelerated or Anthropic erosion, which comes from the intensification of the natural erosive process due to the direct action of man on the soil-plantatmosphere system through the insertion of practices that destroy the balance of the natural conditions of this process (Bertoni and Lombardi Neto, 1999).

According to Morgan (1995), soil erosion is basically caused by the detachment and transport of soil particles by the action of water and wind. The ease with which this process occurs is called soil erodibility, being one of the most worrying factors within agriculture because it directly and indirectly affects the plantation and the environment, being the main cause of the decline in soil fertility, even more in regions where there is greater degradation of the most fertile soil layers (Macedo et al., 2010).

To solve this problem, several researchers have proposed indirect models for predicting soil losses (in the laboratory), which make it possible to consider the spatial and temporal variations of the conditioning factors of erosive processes. These models aim to assist in agricultural planning, to apply conservation techniques that reduce soil losses as much as possible, to minimize environmental and economic damage, and to improve soil quality (Amorim et al., 2010).

The most widely used indirect prediction model in soil science has been the K-factor of

Rev. Ambient. Água vol. 16 n. 6, e2750 - Taubaté 2021 
the Universal Soil Loss Equation (USLE), which expresses the soil's susceptibility to water erosion, capable of estimating soil losses from water erosion throughout the year. The $\mathrm{K}$ factor is important in estimating erosion losses, which is characterized by being a procedure for combining soil characteristics, which allows its assessment through the USLE (Marques et al., 1997; Sá et al., 2004).

Properly managed pasture systems improve soil properties, such as: water retention, aggregate stability, soil organic matter content and nutrient cycling (Franzluebbers et al., 2011). Soares et al. (2016) also found that pasture areas have high percentages of aggregates with larger diameters.

Several studies have applied multivariate statistics to investigations of soil variables in pasture areas (Soares et al., 2016; Assunção et al., 2019; Dias et al., 2019; Zenero et al., 2019). According to Sena et al. (2002), one of the advantages of this technique is the formation of groups of populations with similar characteristics, allowing a better understanding of the variations of the processes that occur in the soil.

Thus, analyzing the spatial variability of the soil, geostatistics has been used as a tool that allows the interpretation and projection of results based on the structure of its natural variability. In addition, it facilitates the understanding of the variability of properties, and of their influence on production, showing the best management alternatives (Silva Neto et al., 2012). Thus, the study estimated soil erodibility and spatial variation using geostatistical techniques in pasture and forest areas in the municipality of Porto Velho-Rondônia.

\section{MATERIAL AND METHODS}

\subsection{Location and characterization of the study area}

The study was carried out in the União Bandeirante District, located in the city of Porto Velho, Rondônia, Brazil. The geographical coordinates are latitude $9^{\circ} 45^{\prime} 32^{\prime \prime} \mathrm{S}$ and longitude 64'31'39" W (Figure 1), which represent three areas, two areas with pastures - brachiaria (Brachiaria brizantha cv. Marandu) and mombaça (Panicum maximum cv. Mombaça); and an area with native forest.

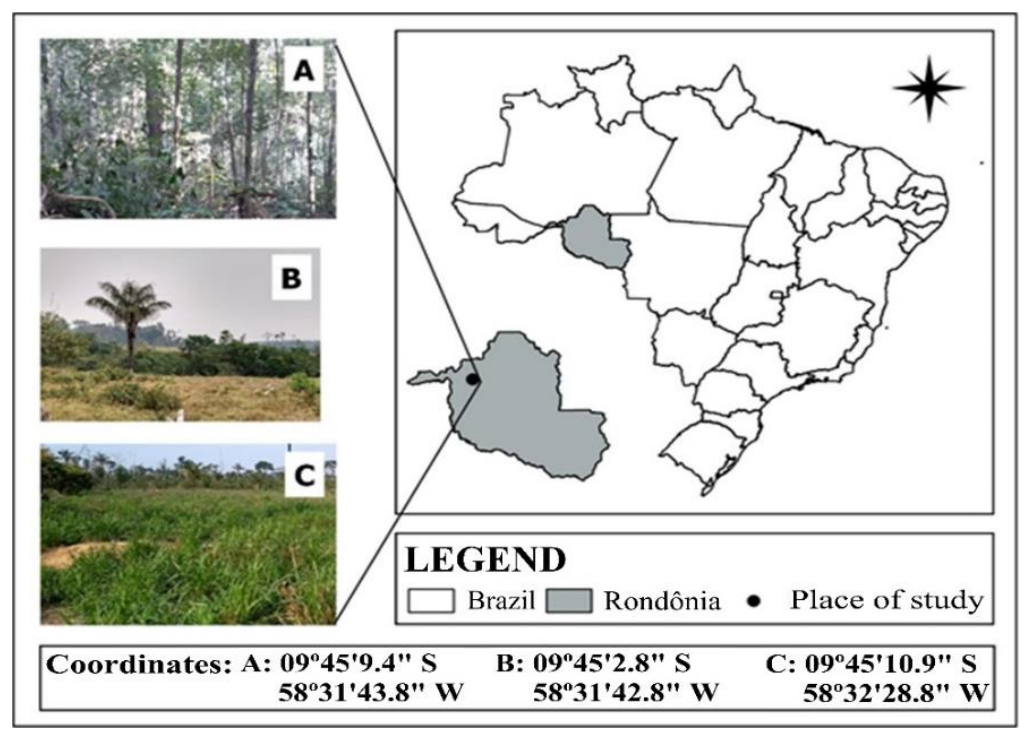

Figure 1. Location map of the study area: A: Forest, B: Brachiaria (Brachiaria brizantha cv. Marandu) and C: Mombaça (Panicum maximum cv. Mombaça), in the municipality of Porto Velho, RO.

The climate of the region belongs to Group A (Tropical Rainy Climate) and climate type Am (monsoon rains) according to the Köppen classification, presenting a short dry season 
between the months of June and September. The annual rainfall ranges from 2,500 to 2,800 $\mathrm{mm}$. The annual temperature is between 24 to $26^{\circ} \mathrm{C}$. The relative humidity is quite high, varying between 85 and $90 \%$ in the rainy season and between 60 to $70 \%$ in the dry season. The local relief is smooth and wavy with altitudes ranging from 100 to $200 \mathrm{~m}$ (Alvares et al., 2013).

The soils found are developed from undifferentiated sedimentary covers, associated with environments of alluvial fans, fluvial channels, flood plains and lakes, made up of sediments whose granulometry varies from gravel to clay, with significant lateritization (Adamy, 2010).

The predominant soils in Rondônia are the Latossolos, which occupy an area of around $58 \%$, being $26 \%$ of the Latossolo Vermelho Amarelo, $16 \%$ of the Latossolo Vermelho and $16 \%$ of the Latossolo Amarelo. Argissolos and Neossolos occupy $11 \%$ of the territory each, Cambissolos occupy $10 \%$ and Gleissolos occupy $9 \%$. The other soil classes occupy the rest of the area (12\%) (Schlindwein et al., 2012). The vegetation typology is called Dense Ombrophilous Forest (IBGE, 2004), composed of dense and multilayered trees between 25 and 30 meters high (Perigolo et al., 2017).

For implantation of pasture areas, deforestation was carried out with successive burning over time, aiming to facilitate the cleaning of areas for later sowing of forages. There are 110 animals raised in the area, which covers 44.28 ha. These animals are rotated every 45 days between paddocks with brachiaria and mombaça grass, using a paddock for each grazing area.

The area with brachiaria is 26.36 ha; it was planted in 2008 and remained unused for one year and was used infrequently until 2010, after which 4.5 animals/ha were used. The area with mombaça grass is $17.92 \mathrm{ha}$; it was introduced in 2007 and was left unused for three years, after which 6.14 animals/ha were used in the 45-day rotation between the brachiaria.

\subsection{Field methodology}

In the field, a $90 \mathrm{~m} \times 60 \mathrm{~m}$ mesh was established for both areas with brachiaria and mombaça grass, and $90 \mathrm{~m} \times 50 \mathrm{~m}$ for the forest area, with a regular spacing of $10 \mathrm{~m}$ between the sampling points for both areas. The crossing points of the meshes were georeferenced with GPS equipment (DATUM WGS 84) for the construction of the Digital Elevation Model (DEM). In each collection area, an altimetric survey was carried out (Figure 2).

The soil was collected at the crossing points of the meshes, at a depth of $0.0-0.2 \mathrm{~m}$, composing 60 sample points for the forest area and 70 points for each pasture area, totaling 200 samples. For each area, we collected soil clods $10 \mathrm{~cm}$ high. These samples were used to determine the organic carbon and the physical properties of the soil.

\subsection{Laboratory methodology}

The collected soil underwent a process of natural drying and breaking, then it was sieved in a $2 \mathrm{~mm}$ mesh, composing the Air-Dried Fine Earth (ADFE) necessary for the analysis of organic carbon (OC) and particle size (sand, silt and clay) following the methodology proposed by Teixeira et al. (2017).

Textural analysis of the soil was determined using the pipette method, with $\mathrm{NaOH}$ solution $1 \mathrm{~mol} \mathrm{~L}^{-1}$ as a chemical dispersant and mechanical agitation using the Wagner type agitator, in a slow rotation apparatus for 16 hours at $50 \mathrm{rpm}$.

The granulometric fractions of the sand obtained from the texture were sieved to determine the dimensions of its solid particles. Each sample was shaken for 3 minutes using a sieve pattern with the following meshes: $2 \mathrm{~mm}, 1 \mathrm{~mm}, 0.5 \mathrm{~mm}, 0.250 \mathrm{~mm}, 0.125 \mathrm{~mm}$ and $0.053 \mathrm{~mm}$. For this fractionation of the sand, a Sieve Agitator (Teixeira et al., 2017) model SOLOTEST was used, necessary to estimate the erodibility factors.

Organic carbon (OC) was determined by the Walkley-Black method (Walkley and Black, 1934), modified by Yeomans and Bremner (1988), in which the OC is oxidized with a mixture of potassium dichromate $0.0667 \mathrm{~mol} \mathrm{~L}^{-1}$ and titrated with ammoniacal ferrous sulphate 0.102 
mol L ${ }^{-1}$ in the presence of the diphenylamine indicator (1\%) (Teixeira et al., 2017). Considering that the OC contributes around 58\% in the composition of the humus, the organic matter (OM) of the soil was estimated by the expression: $\mathrm{OM}=\mathrm{OC} \times 1.724$.

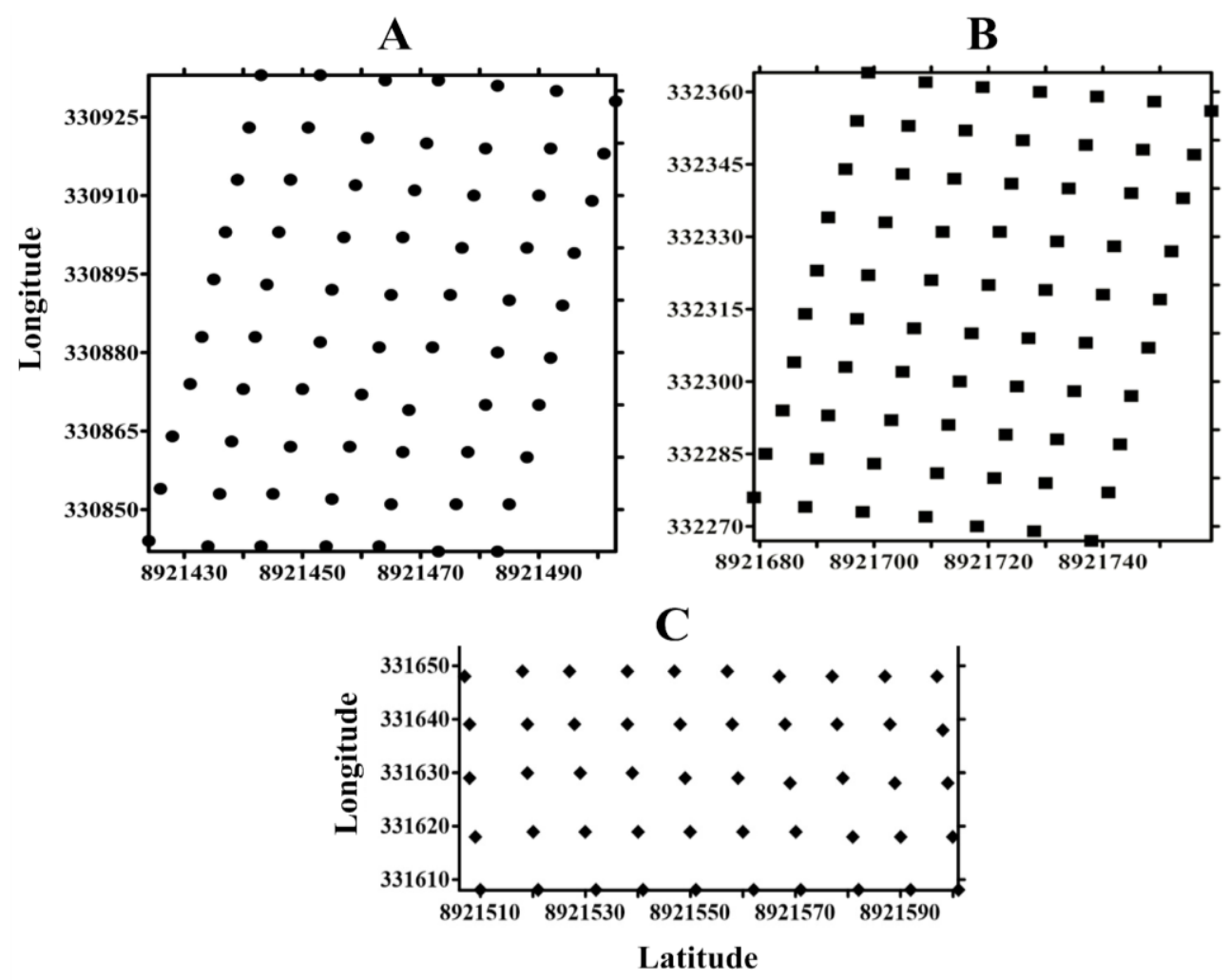

Figure 2. Meshes of the study area: A: Forest, B: Brachiaria (Brachiaria brizantha cv. Marandu) and C: Mombaça (Panicum maximum cv. Mombaça), in the municipality of Porto Velho, RO.

\subsection{Calculation of erodibility factors $\left(K, K_{i}, K_{r}\right)$ and shear stress $\left(\tau_{c}\right)$}

To estimate soil erodibility, indirect prediction models were used, which involve the values of soil attributes analyzed in the laboratory. Thus, in the present work, the USLE (Universal Soil Loss Equation) and the WEPP (Water Erosion Prediction Project) models were used to determine the conditioning factors of erosion in the study sites.

To calculate the global soil erodibility ( $\mathrm{K}$ factor, $\mathrm{t} \mathrm{ha}^{-1} \mathrm{MJ}^{-1} \mathrm{~mm}^{-1} \mathrm{ha}^{-1} \mathrm{~h}$ ), the method modified by Denardin (1990) was used to evaluate K factor in Brazilian soils, according to Equation 1.

$$
K=0.00000748 M+0.00448059 p-0.0631175 X 27+0.01039567 X 32
$$

Where:

$\mathbf{M}=$ new silt $\mathrm{x}$ (new silt + new sand);

$\mathbf{p}=$ permeability coded according to Wischmeier et al (1971);

$\mathbf{X 2 7}=[(0.002 \times$ clay, $\%)+(0.026 \times$ silt,$\%)+(0.075 \mathrm{x}$ very fine sand, $\%)+(0.175 \mathrm{x}$ fine sand, $\%)+(0.375 \times$ medium sand, $\%)+(0.75 \times$ coarse sand, $\%)+(1.5 \times$ very coarse sand, $\%)]$ / (clay, $\%+$ silt, $\%+$ sand, $\%$ );

$\mathbf{X 3 2}=$ new sand $\mathrm{x}(\mathrm{OM} / 100)$;

New silt $=$ silt + very fine sand, $\%$; 
New sand $=$ very coarse sand + coarse sand + medium sand + fine sand, $\%$.

To calculate the interrill erodibility $\left(\mathrm{K}_{\mathrm{i}}, \mathrm{kg} \mathrm{s} \mathrm{m}^{-4}\right)$, rill erodibility $\left(\mathrm{K}_{\mathrm{r}}, \mathrm{s} \mathrm{m}^{-1}\right)$, and the critical shear stress $\left(\tau_{c}, \mathrm{~N} \mathrm{~m}^{-2}\right)$, we use equations from the WEPP model proposed by Flanagan and Livingston (1995) (Equations 2, 3, 4, 5, 6 and 7).

$$
\begin{aligned}
& \mathbf{K}_{\mathbf{i} \text { wepp }}=2728000+192100 \text { VFS sand } \geq 30 \% \\
& \mathbf{K}_{\mathbf{i} \text { wepp }}=6054000-55130 \text { CLAY sand }<30 \% \\
& \mathbf{K}_{\mathbf{r} \text { wepp }}=0.00197+0.00030 \text { VFS }+0.03863 * \text { EXP }(-1.84 * \text { OM }) \text { sand } \geq 30 \% \\
& \mathbf{K}_{\mathbf{r} \text { wepp }}=0.0069+0.134 * \text { EXP }(-0.20 * \text { CLAY }) \text { sand }<30 \% \\
& \boldsymbol{\tau}_{\mathbf{c} \text { wepp }}=2.67+0.065 \text { CLAY }-0.058 \text { VFS sand } \geq 30 \% \\
& \boldsymbol{\tau}_{\mathbf{c} \text { wepp }}=3.5 \text { sand }<30 \%
\end{aligned}
$$

Where:

VFS = very fine sand, \%;

CLAY = clay percentage;

$\mathbf{O M}=$ soil organic matter, \%;

\subsection{Statistical analysis}

\subsubsection{Univariate and descriptive statistics}

After determining the texture, soil organic matter and erodibility factors, univariate statistics (ANOVA) were performed to compare means of the attributes individually by the Tukey test $(\mathrm{p}<0.05)$. Both descriptive statistics and ANOVA were performed using the SPSS 21.0 software (IBM, 2017), in which the values of mean, median, standard deviation, coefficient of variation, asymmetry and kurtosis were calculated. The hypotheses of normality of the data were verified by the Kolmogorov-Smirnov test, using the statistical software Statistica 7.0 (Statsoft, 2004).

The coefficient of variation (CV\%) was assessed according to the classification proposed by Warrick and Nielsen (1980), which classifies soil variables as: CV $<12 \%, 12<\mathrm{CV}<60 \%$, and $\mathrm{CV}>60 \%$ for low, medium and high variability, respectively.

\subsubsection{Multivariate analysis}

For multivariate analysis (MANOVA), a factor analysis extracted by the method of Principal Component Analysis (PCA) was performed to obtain a set of smaller linear combinations of soil attributes that preserve most of the data provided by the soil property (Silva et al., 2010). The PCA aimed to find statistical significance of the sets of soil attributes that most discriminate between the environments under study, obtaining an answer as to in which environments the attributes are more influenced by the anthropic action. In this way, the PC is allowed to evaluate at the same time qualitatively the interactions between soil attributes by standardizing the values of the attributes to mean equal to zero and variance equal to one.

The adequacy of the factor analysis was indicated by the Kaiser-Meyer-Olkin (KMO) measure, which assesses the simple and partial correlations of the variables, and by the Bartlett sphericity test, which accepts or rejects the equality between the correlation and identity 
matrices. The extraction of the factors was performed by the principal component analysis, incorporating the variables that presented commonality equal to or greater than five (5.0), as described by Mingoti (2007). However, the choice of the number of factors to be used was made by the Kaiser criterion (factors that have eigenvalues greater than 1.0), so that they reach an accumulated variance above $70 \%$ of the variance of the variables. In order to simplify the factor analysis, orthogonal rotation (varimax) was performed and represented in a factorial plane of the variables for the principal components (Burak et al., 2010).

\subsubsection{Geostatistical analysis}

Geostatistics was used to assess the spatial variability of the analyzed attributes. For this, it was necessary to know if there is spatial dependence or not on the attributes studied, verified through the graph of the semivariogram. The GS+7.0 software (Robertson, 2004) was used to adjust semivariograms, based on the presupposition of the stationary intrinsic hypothesis (Equation 8).

$\hat{\gamma}(h)=\frac{1}{2 N(h)} \sum_{i=1}^{N(h)}\left[Z\left(x_{i}\right)-Z\left(x_{i}+h\right)\right]^{2}$

Where:

$\gamma(\mathbf{h})=$ semivariance value for a distance $h$;

$\mathbf{N}(\mathbf{h})=$ number of pairs involved in calculating the semivariance;

$\mathbf{Z}\left(\mathbf{x}_{\mathbf{i}}\right)=$ value of attribute $Z$ in position $x_{i}$;

$\mathbf{Z}\left(\mathbf{x}_{\mathbf{i}}+\mathbf{h}\right)=$ value of attribute $Z$ separated by a distance $h$ from position $x_{i}$.

During the adjustment, the coefficients of determination $\left(\mathrm{R}^{2}\right)$ and cross-validation $(\mathrm{C}-\mathrm{V})$ served as the basis for choosing the best theoretical model for the semivariogram. From the choice of the model type (linear, spherical, gaussian, exponential), its parameters were defined (nugget effect $-C_{0}$, sill $-C_{0}+C$, and range $-a$ ).

To analyze the Degree of Spatial Dependence (DSD) of the attributes that presented a spatial dependence structure, the examination of the parameters of the semivariograms proposed by Cambardella et al. (1994) was used. Thus, the semivariograms that have: DSD $\leq$ $25 \%, 25 \%<\mathrm{DSD}<75 \%$, and DSD $>75 \%$ are considered as having strong, moderate and weak spatial dependence, respectively.

After geostatistical modeling, the data generated were interpolated using kriging in the Surfer software Version 13.0 (Golden Software Inc., 1999). Then, the individual semivariograms were scaled for all variables in each area studied, with the aim of reducing them to the same scale, facilitating the comparison of results from different areas (Ceddia et al., 2009).

The experimental semivariograms were scaled by dividing the semi variances by the statistical variance (Guimarães, 1993). Thus, the choice of the scaled semivariogram model that best fitted the data was performed based on the determination coefficient $\left(\mathrm{R}^{2}\right)$, cross-validation $(\mathrm{C}-\mathrm{V})$, in addition to the practical knowledge of the behavior of the attributes in the environments.

\section{RESULTS}

Evaluating the dispersion of the variables (Table 1), it was observed in the pasture areas (brachiaria and mombaça) in comparison with the forest area, that the measures of central tendency (mean and median) of the variables presented symmetrical distribution, and both 
showed values very close for all attributes, which justifies normal or approximately normal distributions of the analyzed data.

Table 1. Descriptive statistics of texture, organic matter and soil erodibility factors in pasture and forest areas in the city of Porto Velho, RO.

\begin{tabular}{|c|c|c|c|c|c|c|c|}
\hline Properties & Mean & Median & Asymmetry & Kurtosis & ${ }^{1}$ S.D. & ${ }^{2} \mathrm{CV} \%$ & ${ }^{3} \mathrm{~K}-\mathrm{S}$ \\
\hline & \multicolumn{7}{|c|}{ Native Forest area } \\
\hline Sand (\%) & $50.67 \mathrm{c}$ & 50.85 & -0.03 & -0.93 & 2.55 & 5.03 & $0.08^{*}$ \\
\hline Silt (\%) & $5.66 \mathbf{a}$ & 5.70 & -0.06 & -0.90 & 1.88 & 33.27 & $0.08^{*}$ \\
\hline Clay $(\%)$ & $42.68 \mathbf{a}$ & 42.74 & -0.14 & -0.69 & 3.00 & 7.03 & $0.09^{*}$ \\
\hline${ }^{4} \mathrm{OM}\left(\mathrm{g} \cdot \mathrm{kg}^{-1}\right)$ & $36.10 \mathbf{a}$ & 35.46 & 0.55 & 0.21 & 4.85 & 13.43 & $0.06^{*}$ \\
\hline${ }^{5}$ Factor K & $0.03 \mathbf{a}$ & 0.03 & 0.13 & -0.48 & 0.00 & 8.65 & $0.08^{*}$ \\
\hline${ }^{6} \mathrm{~K}_{\mathrm{i} \text { wepp }}$ & $3.42 \mathrm{E}^{6} \mathbf{b}$ & $3.38 \mathrm{E}^{6}$ & 0.17 & -1.35 & $2.08 \mathrm{E}^{5}$ & 6.08 & $0.13^{*}$ \\
\hline${ }^{7} \mathrm{~K}_{\mathrm{r} \text { wepp }}$ & $0.0032 \mathbf{b}$ & 0.00 & 0.11 & -1.24 & 0.00 & 10.66 & $0.13^{*}$ \\
\hline \multirow[t]{2}{*}{${ }^{8} \tau_{\mathrm{c} \text { wepp }}$} & $5.29 \mathbf{a}$ & 5.28 & 0.07 & -0.61 & 0.23 & 4.27 & $0.06^{*}$ \\
\hline & \multicolumn{7}{|c|}{ Brachiaria area } \\
\hline Sand (\%) & $66.83 a$ & 67.24 & -0.24 & -1.06 & 2.64 & 3.95 & $0.10^{*}$ \\
\hline Silt (\%) & $2.95 \mathrm{c}$ & 2.86 & 0.18 & -0.90 & 0.89 & 30.07 & $0.06^{*}$ \\
\hline Clay (\%) & $30.11 \mathbf{a}$ & 29.92 & 0.12 & -0.96 & 2.53 & 8.41 & $0.09 *$ \\
\hline${ }^{4} \mathrm{OM}\left(\mathrm{g} \cdot \mathrm{kg}^{-1}\right)$ & $25.65 b$ & 25.85 & -0.01 & -0.55 & 3.93 & 15.33 & $0.05^{*}$ \\
\hline${ }^{5}$ Factor K & $0.01 \mathrm{c}$ & 0.02 & 0.45 & -0.14 & 0.00 & 13.56 & $0.09 *$ \\
\hline${ }^{6} \mathrm{~K}_{\mathrm{i} \text { wepp }}$ & $3.80 \mathrm{E}^{6} \mathbf{a}$ & $3.81 \mathrm{E}^{6}$ & 0.02 & -1.39 & $3.51 \mathrm{E}^{5}$ & 9.23 & $0.13^{*}$ \\
\hline${ }^{7} \mathrm{~K}_{\mathrm{r} \text { wepp }}$ & $0.0042 \mathbf{a}$ & 0.00 & 0.00 & -1.00 & 0.00 & 15.83 & $0.08^{*}$ \\
\hline \multirow[t]{2}{*}{${ }^{8} \tau_{\mathrm{c} \text { wepp }}$} & $4.32 \mathbf{c}$ & 4.30 & 0.36 & -0.53 & 0.22 & 4.99 & $0.07 *$ \\
\hline & \multicolumn{7}{|c|}{ Mombaça area } \\
\hline Sand $(\%)$ & $56.28 \mathrm{~b}$ & 56.65 & -0.45 & 0.57 & 3.61 & 6.41 & $0.13^{*}$ \\
\hline Silt (\%) & $4.45 \mathbf{b}$ & 4.48 & 0.62 & 0.31 & 1.36 & 30.55 & $0.10^{*}$ \\
\hline Clay (\%) & $39.27 \mathbf{b}$ & 38.83 & 0.62 & 0.30 & 3.53 & 9.00 & $0.13^{*}$ \\
\hline${ }^{4} \mathrm{OM}\left(\mathrm{g} \cdot \mathrm{kg}^{-1}\right)$ & $28.43 \mathbf{b}$ & 27.23 & 1.02 & 1.44 & 6.30 & 22.16 & $0.12^{*}$ \\
\hline${ }^{5}$ Factor $\mathrm{K}$ & $0.02 \mathbf{b}$ & 0.02 & 0.80 & 1.53 & 0.00 & 15.18 & $0.07 *$ \\
\hline${ }^{6} \mathrm{~K}_{\mathrm{i} \text { wepp }}$ & $3.23 \mathrm{E}^{6} \mathbf{c}$ & $3.19 \mathrm{E}^{6}$ & 0.35 & -0.68 & $2.34 \mathrm{E}^{5}$ & 7.26 & $0.07 *$ \\
\hline${ }^{7} \mathrm{~K}_{\mathrm{r} \text { wepp }}$ & $0.0031 \mathbf{b}$ & 0.00 & 0.90 & 1.92 & 0.00 & 16.90 & $0.09 *$ \\
\hline${ }^{8} \tau_{\text {c wepp }}$ & $5.07 \mathbf{b}$ & 5.02 & 0.60 & -0.03 & 0.26 & 5.11 & $0.10^{*}$ \\
\hline
\end{tabular}

Means followed by equal letters in the column do not differ by Tukey's test at the $5 \%$ probability level. ${ }^{1}$ S.D.: standard deviation; ${ }^{2} \mathrm{CV} \%$ : coefficient of variation, \%; ${ }^{3} \mathrm{~K}-\mathrm{S}$ : normality test (Kolmogorov-Smirnov significant at $5 \%$ probability); ${ }^{4} \mathrm{OM}$ : organic matter; ${ }^{5} \mathrm{~K}$ : soil erodibility, t.ha ${ }^{-1} \cdot \mathrm{MJ}^{-1} \cdot \mathrm{mm}^{-1}$.ha.h; ${ }^{6} \mathrm{~K}_{\mathrm{i} \text { wepp}}$ : interrill erodibility, kg.s.m ${ }^{-4}$; ${ }^{7} \mathrm{~K}_{\mathrm{r} \text { wepp}}$ : rill erodibility, $\mathrm{kg} . \mathrm{N}^{-1} \cdot \mathrm{s}^{-1} ;{ }^{8} \tau_{\mathrm{c} \text { wepp }}$ : critical shear stress, N.m ${ }^{-2}$.

It was noted through the texture results that the average values in the forest area indicate that this area has more clay, more organic matter and higher values of $K$ and $\tau_{c \text { wepp }}$ than in the areas with pastures.

Thus, the asymmetry values ranged from -0.45 to 1.02 , where variables with values greater than zero represent data with an asymmetric distribution on the right while the negatives indicate that they have an asymmetric distribution on the left. For kurtosis, values from -0.03 to 1.92 were observed; these values should preferably be null; however, values between -2 to +2 are acceptable (Negreiros Neto et al., 2014).

In the mombaça grass area, it was found that the standard deviation values were high, highlighting the value of $6.30 \mathrm{~g} . \mathrm{kg}^{-1}$ for organic matter $(\mathrm{OM})$. For the forest area, the OM presented a standard deviation value equal to $4.85 \mathrm{~g}_{\mathrm{kg}} \mathrm{kg}^{-1}$ and the lowest value found for the 
brachiaria area $\left(3.93 \mathrm{~g} \cdot \mathrm{kg}^{-1}\right)$.

Through the classification of the variation coefficient (CV\%) proposed by Warrick and Nielsen (1980), it was found that the highest value was found in the forest area $(33.27 \%)$, followed by the mombaça grass area $(30.55 \%)$ and brachiaria $(30.07 \%$,), all for the variable silt, being classified as medium variability of the data. The variable with the least variability was sand, with a value of $3.95 \%$ in the brachiaria area.

In general, the $\mathrm{K}$ factor for all areas showed normal hypothetical data distribution using the Kolmogorov-Smirnov test at $5 \%$ probability. Thus, the erodibility factors $\mathrm{K}, \mathrm{K}_{\mathrm{i}}$ wepp and $\tau_{\mathrm{c}}$ wepp showed low variability for the forest area, indicating a good homogeneity of the area, in addition to a good representativeness of the samplings performed.

However, the $\mathrm{K}$ factor $\left(\mathrm{t} \mathrm{ha}^{-1} \mathrm{MJ}^{-1} \mathrm{~mm}^{-1}\right.$ ha $\left.\mathrm{h}\right)$ was lower in the brachiaria area $(0.01)$, and a higher value was observed in the forest area (0.03), as in Table 1. Thus, the high value in the forest area may be related to the high content of OM present, which does not match the types of soils for which USLE was developed and adapted.

Table 2 shows the parameters of the adjusted semivariograms that best describe the spatial distribution of the analyzed attributes. It was confirmed that in the forest area, the attributes have a spatial dependence structure with a moderate degree for sand $(27.70 \%)$ and with a strong spatial dependence for all other attributes (DSD < 25\%). Some variables showed a condition of

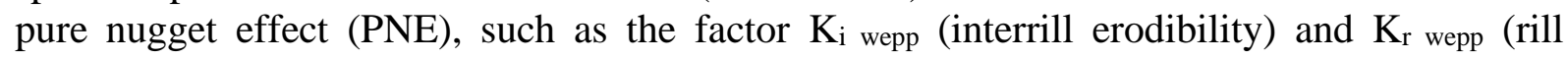
erodibility), that is, they did not show a spatial dependence structure.

On the other hand, in the brachiaria area the variable $\tau_{\mathrm{c} \text { wepp }}$ showed moderate spatial dependence, with a value of $28.10 \%$ and the other variables a strong spatial dependence (DSD $<25 \%$ ). In the mombaça area, it is observed that the variables sand, clay and organic matter showed strong DSD, with moderate DSD for the other variables, showing that possibly the mombaça grass area is more influenced by the intrinsic properties of the soil linked to the formation factors (Cambardella et al., 1994).

Table 2. Models and parameters estimated for semivariograms, under 0.0-0.2 m layer, in forest and pasture areas in the municipality of Porto Velho, RO.

\begin{tabular}{|c|c|c|c|c|c|c|c|c|c|c|c|c|c|c|c|c|c|c|}
\hline \multirow[t]{2}{*}{$\begin{array}{l}\text { Attri } \\
\text { bute }\end{array}$} & \multicolumn{6}{|c|}{ Forest } & \multicolumn{6}{|c|}{ Brachiaria } & \multicolumn{6}{|c|}{ Mombaça } \\
\hline & $\begin{array}{l}\text { Mo } \\
\text { d. }\end{array}$ & $\mathrm{C}_{0}$ & $\begin{array}{c}\mathrm{C}_{0+}+ \\
\mathrm{C}_{1}\end{array}$ & $\begin{array}{c}\mathrm{a} \\
(\mathrm{m})\end{array}$ & $\mathrm{R}^{2}$ & $\begin{array}{l}\mathrm{DS} \\
\mathrm{D} \% \\
\end{array}$ & $\begin{array}{l}\text { Mo } \\
\text { d. }\end{array}$ & $\mathrm{C}_{0}$ & $\begin{array}{c}\mathrm{C}_{0}+ \\
\mathrm{C}_{1}\end{array}$ & $\begin{array}{c}\mathrm{a} \\
(\mathrm{m})\end{array}$ & $\mathrm{R}^{2}$ & $\begin{array}{l}\text { DS } \\
\text { D\% }\end{array}$ & $\begin{array}{c}\text { Mo } \\
\text { d. }\end{array}$ & $\mathrm{C}_{0}$ & $\begin{array}{c}\mathrm{C}_{0}+ \\
\mathrm{C}_{1}\end{array}$ & $\begin{array}{c}\mathrm{a} \\
(\mathrm{m})\end{array}$ & $\mathrm{R}^{2}$ & $\begin{array}{l}\text { DS } \\
\text { D\% }\end{array}$ \\
\hline Sand & $\begin{array}{l}\text { Ex } \\
\text { p. }\end{array}$ & $\begin{array}{l}3 . \\
68\end{array}$ & $\begin{array}{l}13 . \\
28\end{array}$ & $\begin{array}{l}79 . \\
29\end{array}$ & $\begin{array}{l}0 . \\
92\end{array}$ & $\begin{array}{c}27.7 \\
0\end{array}$ & $\begin{array}{c}\mathrm{Ga} \\
\mathrm{u} .\end{array}$ & $\begin{array}{l}2 . \\
31\end{array}$ & $\begin{array}{l}18 . \\
94\end{array}$ & $\begin{array}{l}89 . \\
21\end{array}$ & 0. & $\begin{array}{c}12.2 \\
0\end{array}$ & $\begin{array}{c}\text { Ex } \\
\text { p. }\end{array}$ & $\begin{array}{l}1 . \\
85\end{array}$ & $\begin{array}{l}16 . \\
02\end{array}$ & $\begin{array}{c}72 . \\
00\end{array}$ & 0 & $\begin{array}{c}11.5 \\
0\end{array}$ \\
\hline Silt & $\begin{array}{l}\text { Ex } \\
\text { p. }\end{array}$ & $\begin{array}{c}0 . \\
83\end{array}$ & $\begin{array}{c}6.1 \\
8\end{array}$ & $\begin{array}{l}25 . \\
20\end{array}$ & $\begin{array}{l}0 . \\
85\end{array}$ & $\begin{array}{c}13.4 \\
0\end{array}$ & Lin & - & - & - & - & $\begin{array}{c}\text { PN } \\
\text { E }\end{array}$ & $\begin{array}{l}\text { Ex } \\
\text { p. }\end{array}$ & $\begin{array}{l}0 . \\
46\end{array}$ & $\begin{array}{c}1.3 \\
0\end{array}$ & $\begin{array}{c}27 . \\
60\end{array}$ & $\begin{array}{c}0 . \\
81\end{array}$ & $\begin{array}{c}35.5 \\
0\end{array}$ \\
\hline Clay & $\begin{array}{l}\text { Ex } \\
\text { p. }\end{array}$ & $\begin{array}{c}0 . \\
01\end{array}$ & $\begin{array}{l}14 . \\
51\end{array}$ & $\begin{array}{c}40 . \\
50\end{array}$ & $\begin{array}{c}0 . \\
90\end{array}$ & 0.10 & $\begin{array}{l}\text { Ex } \\
\text { p. }\end{array}$ & $\begin{array}{l}0 . \\
10\end{array}$ & $\begin{array}{l}14 . \\
89\end{array}$ & $\begin{array}{c}90 . \\
00\end{array}$ & $\begin{array}{c}0 . \\
90\end{array}$ & 0.70 & $\begin{array}{l}\text { Ex } \\
\text { p. }\end{array}$ & $\begin{array}{l}2 . \\
52\end{array}$ & $\begin{array}{l}17 . \\
26\end{array}$ & $\begin{array}{c}90 . \\
00\end{array}$ & $\begin{array}{c}0 . \\
90\end{array}$ & $\begin{array}{c}14.6 \\
0\end{array}$ \\
\hline $\mathrm{OM}$ & $\begin{array}{l}\text { Sp } \\
\text { h. }\end{array}$ & $\begin{array}{c}0 . \\
02\end{array}$ & $\begin{array}{l}32 . \\
54\end{array}$ & $\begin{array}{l}22 . \\
80\end{array}$ & $\begin{array}{c}0 . \\
80\end{array}$ & 0.60 & $\begin{array}{l}\text { Sp } \\
\text { h. }\end{array}$ & $\begin{array}{c}0 . \\
01\end{array}$ & $\begin{array}{l}15 . \\
03\end{array}$ & $\begin{array}{c}20 . \\
69\end{array}$ & $\begin{array}{l}0 . \\
71\end{array}$ & 0.00 & $\begin{array}{l}\text { Sp } \\
\text { h. }\end{array}$ & $\begin{array}{l}7 . \\
52\end{array}$ & $\begin{array}{l}30 . \\
07\end{array}$ & $\begin{array}{l}17 . \\
60\end{array}$ & $\begin{array}{l}0 . \\
71\end{array}$ & $\begin{array}{c}25.0 \\
0\end{array}$ \\
\hline $\begin{array}{c}\mathrm{K} \\
\text { Factor }\end{array}$ & $\begin{array}{l}\text { Ex } \\
\text { p. }\end{array}$ & $\begin{array}{c}0 . \\
00\end{array}$ & $\begin{array}{c}0.0 \\
0\end{array}$ & $\begin{array}{c}32 . \\
40\end{array}$ & $\begin{array}{l}0 . \\
77\end{array}$ & 0.00 & $\begin{array}{l}\text { Ex } \\
\text { p. }\end{array}$ & $\begin{array}{c}0 . \\
00\end{array}$ & $\begin{array}{c}0.0 \\
0\end{array}$ & $\begin{array}{l}39 . \\
90\end{array}$ & $\begin{array}{l}0 . \\
71\end{array}$ & 0.00 & $\begin{array}{c}\text { Ex } \\
\text { p. }\end{array}$ & $\begin{array}{c}0 . \\
00\end{array}$ & $\begin{array}{c}0.0 \\
0\end{array}$ & $\begin{array}{l}27 . \\
84\end{array}$ & $\begin{array}{l}0 . \\
70\end{array}$ & $\begin{array}{c}37.5 \\
0\end{array}$ \\
\hline $\mathrm{K}_{\mathrm{i} \text { wepp }}$ & Lin & - & - & - & - & $\begin{array}{c}\text { PN } \\
\text { E }\end{array}$ & Lin & - & - & - & - & $\begin{array}{c}\text { PN } \\
\text { E }\end{array}$ & Lin & - & - & 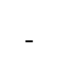 & - & $\begin{array}{c}\text { PN } \\
\text { E }\end{array}$ \\
\hline $\mathrm{K}_{\mathrm{r} \text { wepp }}$ & Lin & - & - & - & - & $\begin{array}{c}\text { PN } \\
\text { E }\end{array}$ & Lin & - & - & - & - & $\begin{array}{c}\text { PN } \\
\text { E }\end{array}$ & Lin & - & . & . & - & $\begin{array}{c}\text { PN } \\
\text { E }\end{array}$ \\
\hline$\tau_{\mathrm{c} \text { wepp }}$ & $\begin{array}{l}\text { Ex } \\
\text { p. }\end{array}$ & $\begin{array}{c}0 . \\
01\end{array}$ & $\begin{array}{c}0.0 \\
8 \\
\end{array}$ & $\begin{array}{c}48 . \\
00\end{array}$ & $\begin{array}{l}0 . \\
81 \\
\end{array}$ & $\begin{array}{c}15.4 \\
0 \\
\end{array}$ & $\begin{array}{l}\text { Ex } \\
\text { p. }\end{array}$ & $\begin{array}{l}0 . \\
03\end{array}$ & $\begin{array}{c}0.0 \\
3 \\
\end{array}$ & $\begin{array}{l}86 . \\
78 \\
\end{array}$ & $\begin{array}{l}0 . \\
95 \\
\end{array}$ & $\begin{array}{c}28.1 \\
0 \\
\end{array}$ & $\begin{array}{l}\text { Ex } \\
\text { p. }\end{array}$ & $\begin{array}{c}0 . \\
02\end{array}$ & $\begin{array}{c}0.0 \\
8 \\
\end{array}$ & $\begin{array}{c}86 . \\
40 \\
\end{array}$ & $\begin{array}{c}0 . \\
86 \\
\end{array}$ & $\begin{array}{c}28.4 \\
0 \\
\end{array}$ \\
\hline
\end{tabular}

Mod.: Model; Sph.: Spherical; Exp.: Exponential; Lin.: Linear; Gau.: Gaussian; $C_{0}$ : Nugget effect; $\mathrm{C}_{0}+\mathrm{C}_{1}$ : Sill; a: Range; $\mathrm{R}^{2}$ : Coefficient of determination; DSD\%: Degree of Spatial Dependence; OM: Organic Matter; PNE: Pure Nugget Effect; K: Erodibility of the soil; $\mathrm{K}_{\mathrm{i} \text { wepp }}$ : interrill erodibility; $\mathrm{K}_{\mathrm{r} \text { wepp: }}$ : rill erodibility; $\tau_{\mathrm{c} \text { wepp: }}$ critical shear stress.

The adjustments of the experimental semivariograms, kriging maps and spatial dependence analysis are shown in Figures 3, 4, 5, 6, 7 and 8, for the forest, brachiaria and mombaça grass areas. 

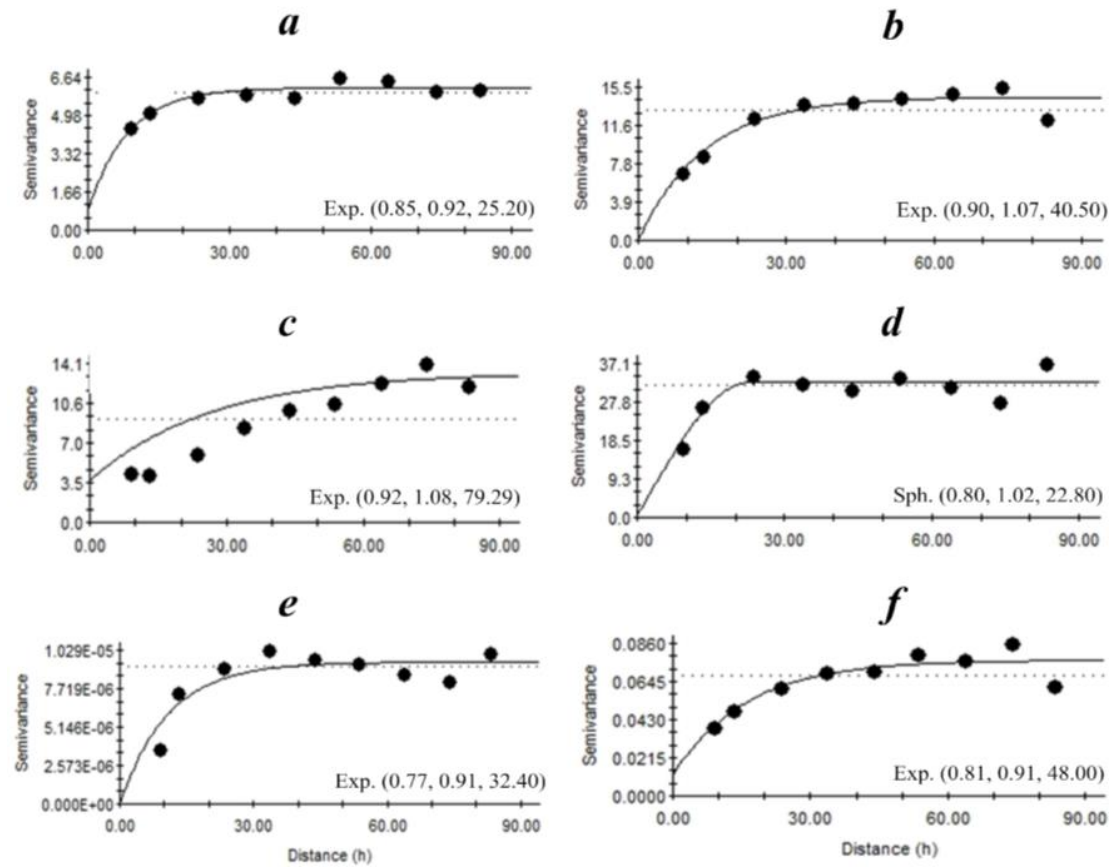

Figure 3. Experimental semivariograms adjusted for erodibility factors at a depth of $0.0-0.2 \mathrm{~m}$, in a forest area in the municipality of Porto Velho, RO. The letters represent the attributes: silt $(a)$, clay $(b)$, sand $(c)$, OM $(d), \mathrm{K}$ factor $(e)$ and shear stress $(f)$. The values in parentheses represent, respectively: coefficient of determination $\left(\mathrm{R}^{2}\right)$, crossvalidation $(\mathrm{C}-\mathrm{V})$ and range $(a)$.

$g$
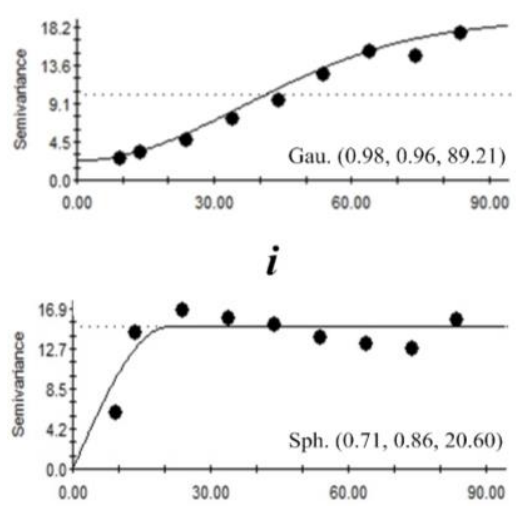
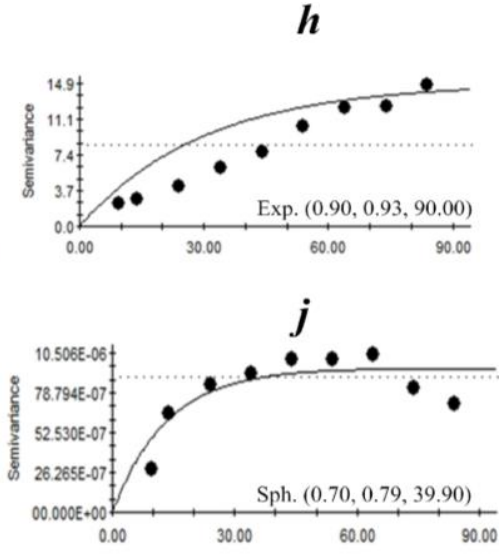

$\boldsymbol{k}$

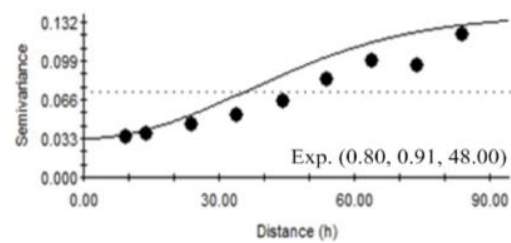

Figure 4. Experimental semivariograms adjusted for erodibility factors at a depth of $0.0-0.2 \mathrm{~m}$, in a brachiaria area in the municipality of Porto Velho, RO. The letters represent the attributes: sand $(g)$, clay $(h), \mathrm{OM}(i), \mathrm{K}$ factor $(j)$ and shear stress $(k)$. The values in parentheses represent, respectively: coefficient of determination $\left(\mathrm{R}^{2}\right)$, cross-validation $(\mathrm{C}-\mathrm{V})$ and range $(a)$. 

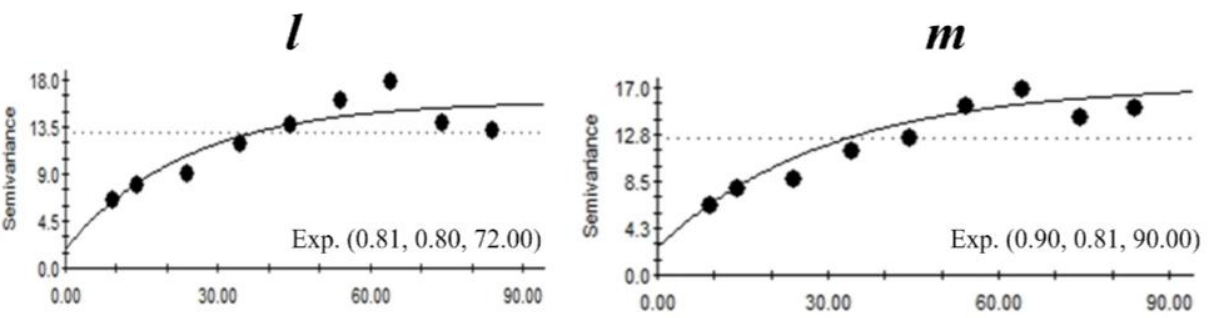

n
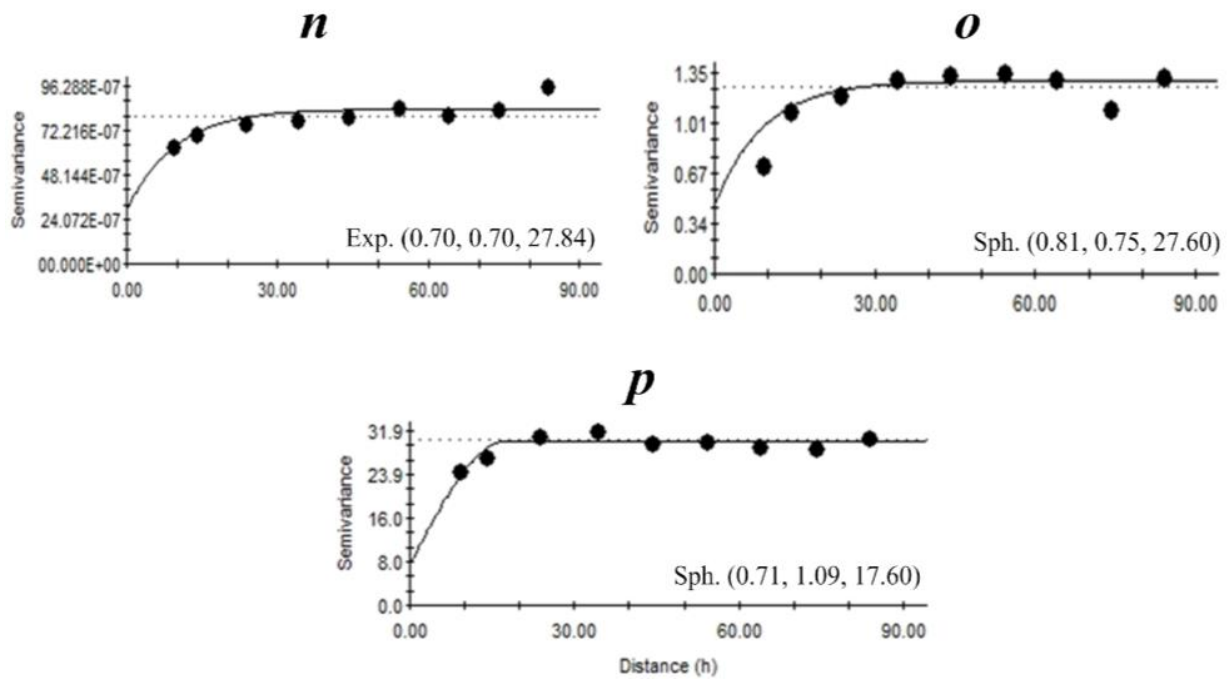

Figure 5. Experimental semivariograms adjusted for erodibility factors at a depth of 0.0-0.2 m, in a mombaça grass area in the municipality of Porto Velho, RO. The letters represent the attributes: sand $(l)$, clay $(m), \mathrm{K}$ factor $(n)$, silt $(o)$, and $\mathrm{OM}(p)$. The values in parentheses represent, respectively: coefficient of determination $\left(\mathrm{R}^{2}\right)$, cross-validation $(\mathrm{C}-\mathrm{V})$ and range $(a)$.
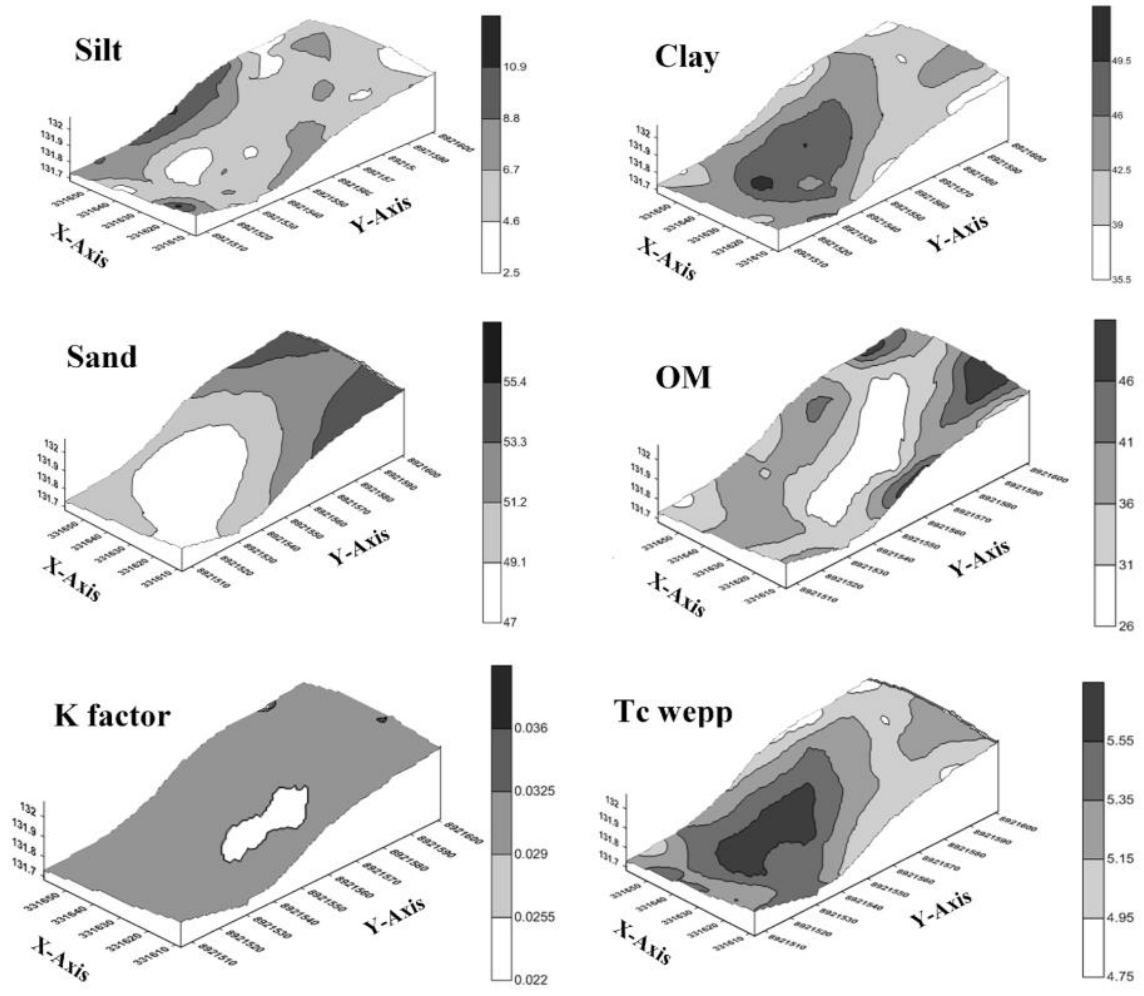

Figure 6. Kriging maps of soil attributes and erodibility factors in a native forest area in the municipality of Porto Velho, RO. 

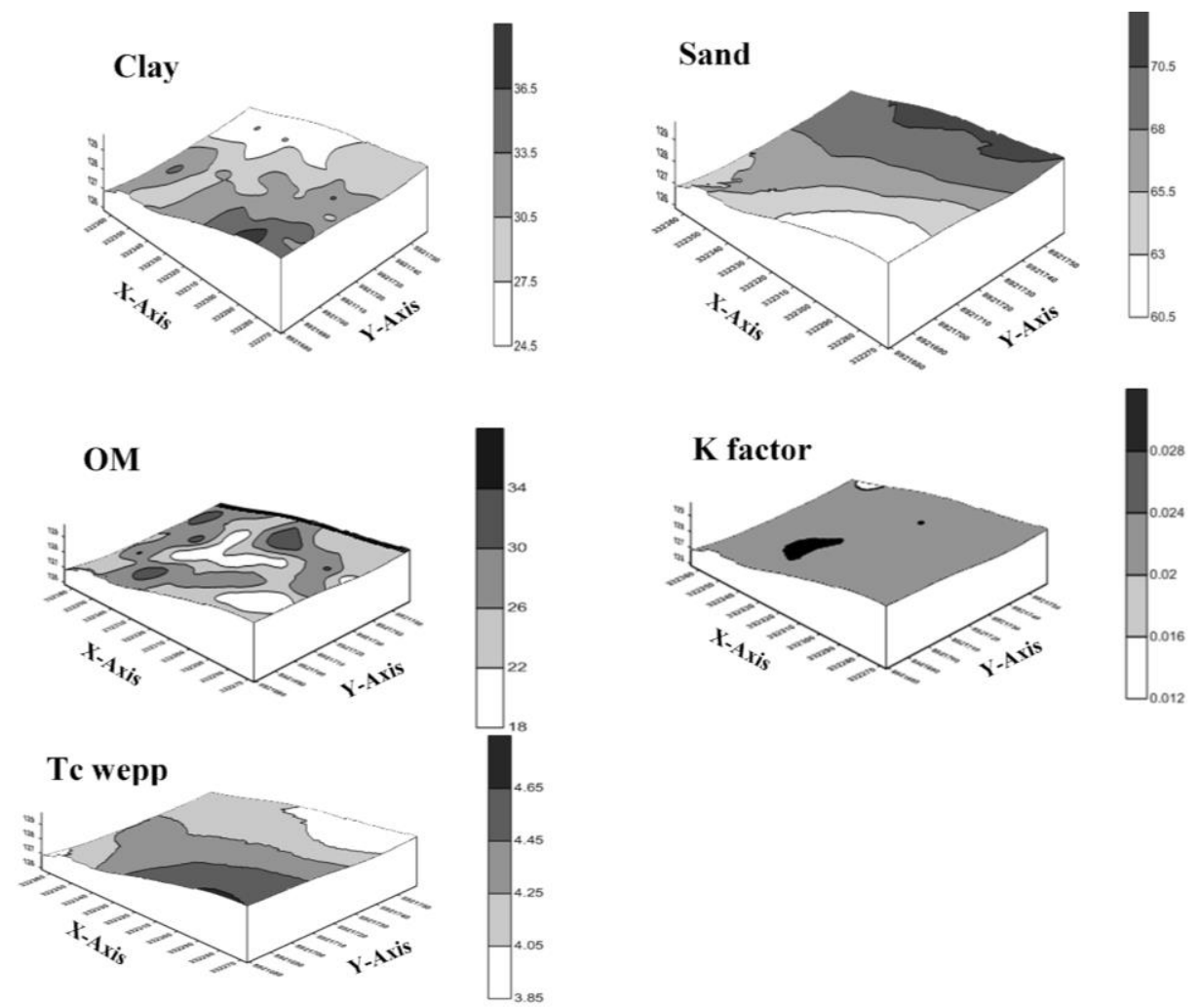

Figure 7. Kriging maps of soil attributes and erodibility factors in a brachiaria area in the municipality of Porto Velho, RO.
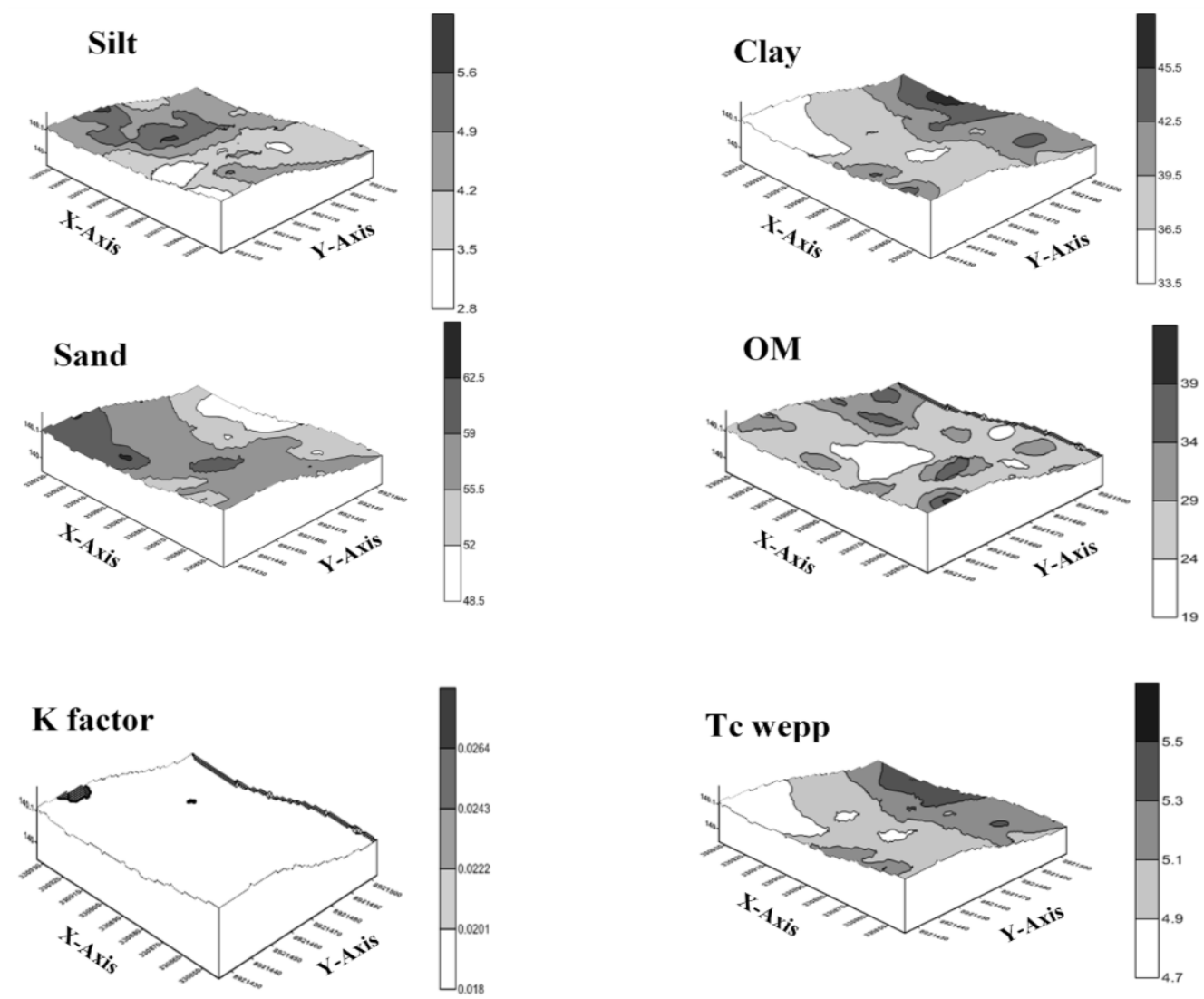

Figure 8. Kriging maps of soil attributes and erodibility factors in a mombaça area in the municipality of Porto Velho, RO. 
Through the results, it was possible to observe that the attributes showed spatial dependence, adjusting predominantly to the exponential and spherical models with values of $\mathrm{R}^{2}$ above 0.70 for all areas.

Oliveira et al. (2015a), studying soils in Amazonas, observed the predominance of the spherical model in forest area and exponential model in pastures to the adjustment of semivariograms for soil attributes.

The coefficient of determination showed values ranging from 0.71 to 0.98 while crossvalidation varied from 0.71 to 1.00 for all areas. According to Azevedo (2004), the more the $\mathrm{R}^{2}$ is close to 1.00 , the better the estimation of the values by the common kriging method.

The scaled semivariograms for the three areas studied are shown in Figure 9. The model adjusted to the graphs is exponential for the three areas, which showed $\mathrm{R}^{2}$ performance between 0.57 to 0.69 and cross-validation between 0.76 to 0.83 . Oliveira et al. (2015b) also observed that, in forest and pastures areas, the exponential model fits better for the chemical attributes of the soil.
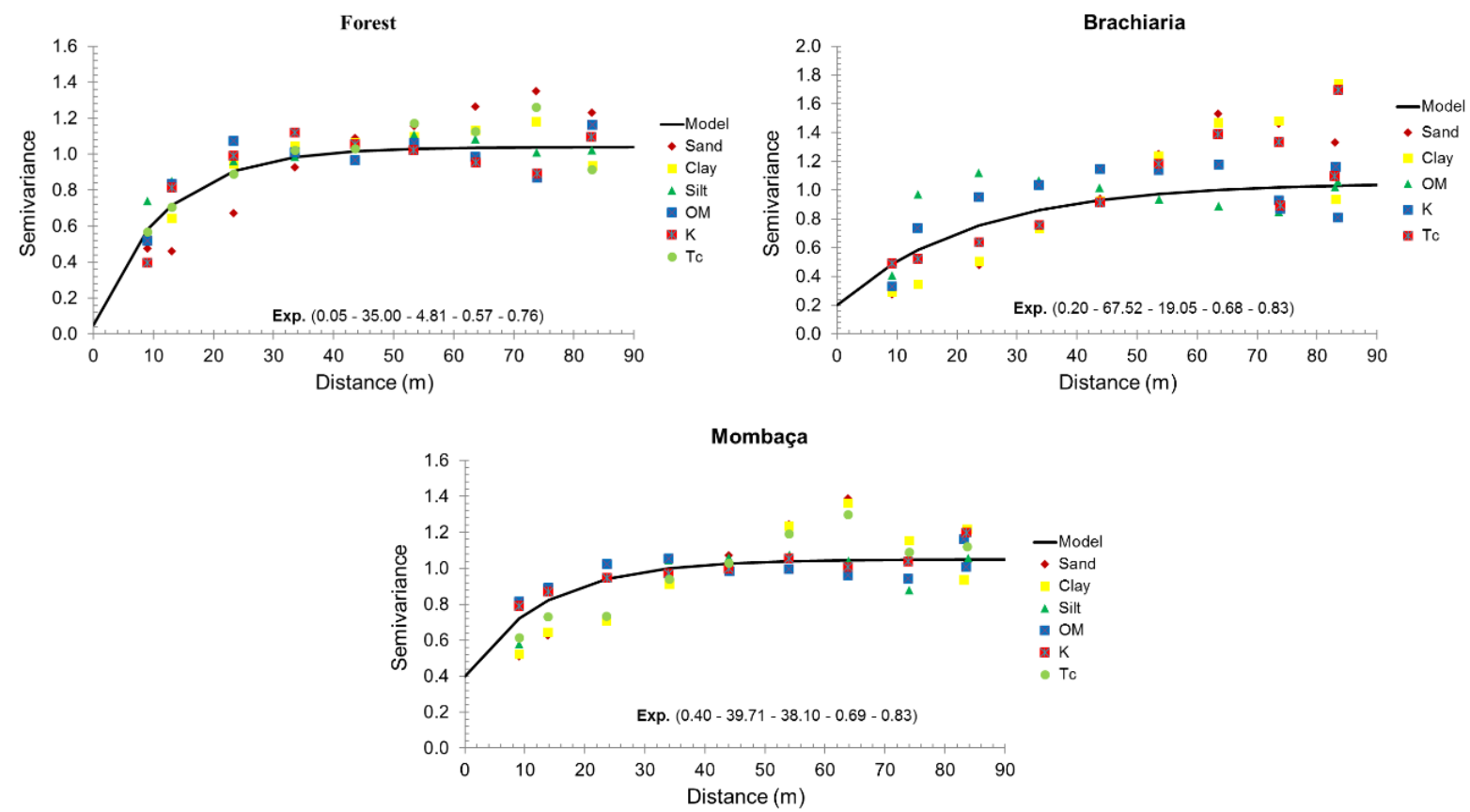

Figure 9. Scaled semivariograms for the environments studied in Porto Velho, Rondônia. The values in parentheses indicate respectively: nugget effect $\left(C_{0}\right)$, range $(a)$, Degree of Spatial Dependence (DSD\%), coefficient of determination $\left(\mathrm{R}^{2}\right)$ and cross-validation $(\mathrm{C}-\mathrm{V})$.

The areas presented range values (a) ranging from 35.00 to $67.52 \mathrm{~m}$, with the highest value being found for the brachiaria area and the lowest value in the native forest area. In relation to $\mathrm{DSD} \%$, the forest and brachiaria area showed variables with strong spatial dependence. In contrast, the mombaça grass area showed moderate spatial dependence (Cambardella et al., 1994).

The factor analysis showed significant results $(\mathrm{KMO}=0.772 ; \mathrm{p}<0.05$, for the Barlett sphericity test) for the variables in the evaluated areas, showing suitability for the construction of the Principal Components (Figure 10).

In the principal component analysis (PCA), with the variables with the highest scores, two main components were extracted, which could explain the total variability of the data for the 0.0-0.2 $\mathrm{m}$ depth, in which the studied environments were influenced by the high levels of sand and clay, which interfere with soil compaction and OM accumulation (Table 3 and Figure 10).

However, each area had a well-distributed score distribution within the factorial plane, 
discriminating the specific characteristics presented by the type of management adopted in each studied area.

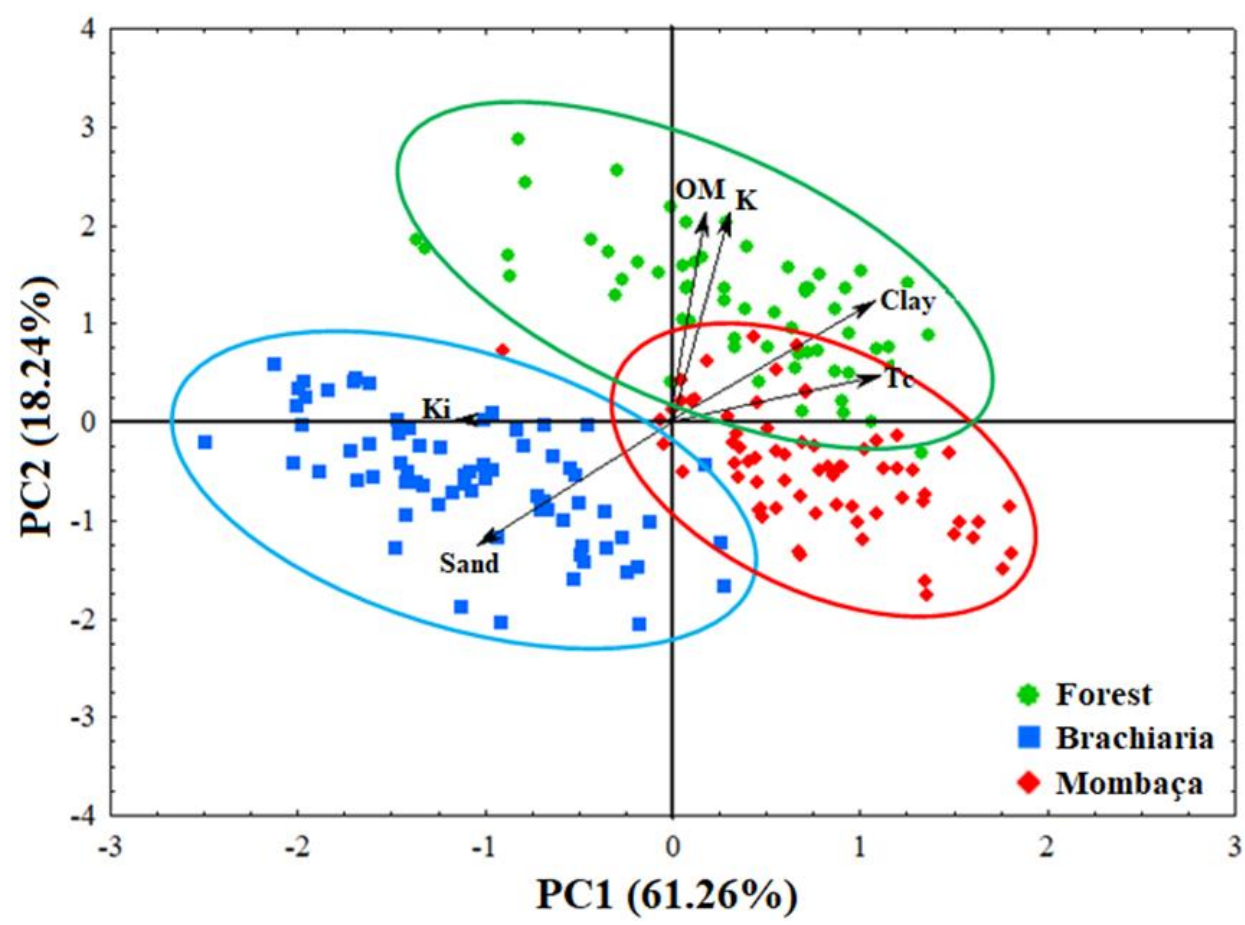

Figure 10. Principal component analysis of soil attributes at $0.0-0.2 \mathrm{~m}$ depth in pastures and forest areas in the municipality of Porto Velho, RO.

Table 3. Correlation between each principal component with soil texture and erodibility.

\begin{tabular}{|c|c|c|c|}
\hline \multirow{2}{*}{ Attributes } & \multirow{2}{*}{ Common Variation } & \multicolumn{2}{|c|}{ Factors } \\
\hline & & PC1 & PC2 \\
\hline Clay & 0.89 & $0.77 *$ & 0.52 \\
\hline Sand & 0.89 & $-0.73^{*}$ & -0.56 \\
\hline $\mathrm{OM}$ & 0.60 & 0.12 & $0.91 *$ \\
\hline $\mathrm{K}$ & 0.67 & 0.22 & $0.90 *$ \\
\hline $\mathrm{K}_{\mathrm{i} \text { wepp }}$ & 0.34 & $-0.82 *$ & -0.01 \\
\hline $\mathrm{T}_{\mathrm{c} \text { wepp }}$ & 0.42 & $0.78^{*}$ & 0.18 \\
\hline \multicolumn{2}{|c|}{ Explanatory Variance } & 61.26 & 18.24 \\
\hline
\end{tabular}

\section{DISCUSSION}

Studies highlight that asymmetry and kurtosis are indicators of data distribution; however, they are more sensitive to extreme values than the mean and median, and such values close to zero indicate greater normality of the data (Kamimura et al., 2013; Alho et al., 2016), with symmetrical values or not, the ideal is that these values are close to the central zero value (Cortez et al., 2011). For kurtosis, values of - 0.03 to 1.92 were observed; these values should preferably be null, however values between -2 to +2 are acceptable (Negreiros Neto et al., 2014).

According to Oliveira et al. (2015a), the statistical measure of CV\% allows comparing the 
variability between samples of variables with different units; however, it does not allow analyzing the spatial variability of soil attributes. Considering that the CV\% indicates the variability of the data in relation to the mean, the smaller the value the more homogeneous the data set is, it is possible to evaluate the homogeneous condition for the results found in the present study.

According to Frogbrook et al. (2002), high values of CV\% can be considered as the first indicators of the existence of heterogeneity in the data. Thus, based on the CV\% values found, it was possible to state that the analyzed attributes presented low to medium variation for the studied areas, corroborating the results found by Cunha et al. (2017).

In general, analyzing the results of factor $\mathrm{K}$, it was observed that they were lower than the values of $5.21 \times 10^{-2} \mathrm{tha}^{-1} \mathrm{MJ}^{-1} \mathrm{~mm}^{-1}$ ha $\mathrm{h}$, found by Nunes et al. (2017) studying the application of the universal equation of soil losses in Argissolos in the southern region of Amazonas.

According to Castro et al. (2011), the K factor, can be classified into classes according to its potential, so that the authors adopt the following classifications: $\mathrm{K}<9.00 \times 10^{-3}$ (very low); $9.00 \times 10^{-3}<\mathrm{K} \leq 1.50 \times 10^{-2}$ (low); $1.50 \times 10^{-2}<\mathrm{K} \leq 3.00 \times 10^{-2}$ (mean); $3.00 \times 10^{-2}<\mathrm{K} \leq$ $4.50 \times 10^{-2}$ (high); $4.50 \times 10^{-2}<\mathrm{K} \leq 6.00 \times 10^{-2}$ (very high), and $\mathrm{K}>6.00 \times 10^{-2}$ (extremely high).

In this sense, taking into account that values found in the three areas studied ranged from 0.01 to $0.03 \mathrm{t} \mathrm{ha}^{-1} \mathrm{MJ}^{-1} \mathrm{~mm}^{-1}$ ha, it was possible to classify the areas in the following classes: low erodibility for the brachiaria area; and medium erodibility for mombaça grass and forest.

However, the forest area is located in areas considered to be flatter, allowing less conditions for sediment losses caused by water erosion, since it is the main form of degradation of Brazilian soils, caused by rain drops and runoff, which carry suspended soil particles, nutrients, organic matter and chemicals, causing serious damage to agricultural activities (Bertol et al., 2007).

Regarding $\mathrm{K}_{\mathrm{i} \text { wepp }}$ and $\mathrm{K}_{\mathrm{r} \text { wepp }}$, it was possible to observe that the brachiaria area had the highest value compared to the other areas studied, with a clear significant difference between them. In general, pasture areas, although well managed, are heterogeneous, and this problem can be even more accentuated when pastures are established in sloping areas (Artur et al., 2014).

When assessing the difference in texture for the three environments studied, it is observed that all areas at a depth of 0-0.2 m, showed a statistical difference (Table 1). When analyzing the fractions, it was observed that the sand fraction of the forest and pasture areas showed a significant difference between them by the Tukey test. The brachiaria area showed a medium texture, with high sand contents, while the forest and mombaça grass areas were clayey. The high levels of sand in the brachiaria area may be related to the topography of the respective areas, due to the flood of small particles of the mineral fraction (clay) and organic matter, which are transported by surface runoff. In general, studies highlight that the topography of the terrain has a strong influence on erosion losses, especially due to the degree of slope and the length of the ramp (Campos et al., 2008).

Range $(a)$ is a parameter of geostatistics that has served as a basis for sample planning, indicating the maximum distance at which the attribute is spatially correlated (Dalchiavon et al., 2012). Reflecting the degree of homogenization between the samples, the higher the value, the more homogeneous the phenomenon or process will be studied. Range values ranging from $22.80(\mathrm{OM})$ to $79.29 \mathrm{~m}$ (sand) were observed, followed by brachiaria from $20.69(\mathrm{OM})$ to 90.00 $\mathrm{m}$ (clay) and for mombaça grass $17.60(\mathrm{OM})$ at $90.00 \mathrm{~m}$ (clay). This means that all neighbors within this radius can be used to estimate values in closer spacing, and that all samples are correlated and dependent on each other at the same distance from each other.

The area with brachiaria showed higher values of range in relation to the other areas, indicating that the area of brachiaria has less variability and is more homogeneous. In contrast, the area with mombaça grass showed smaller values of range, indicating that this area has 
greater variability, thus being more heterogeneous. Thus, this greater variability in the area of mombaça grass may be related to the greater grazing intensity (Alencar et al., 2016).

The Degree of Spatial Dependence (DSD) presented values varying from 0.00 to $37.50 \%$ between the studied areas, presenting strong spatial dependence (DSD $<25 \%$ ) and moderate $(26 \%<\mathrm{DSD}<75 \%)$ (Cambardella et al., 1994), indicating that the studied variables are not randomly distributed in space (Cavalcante et al., 2011).

The mombaça grass area showed a strong DSD for most of the variables compared to the variables of the forest and brachiaria environments, showing that possibly the mombaça grass area is more influenced by the intrinsic properties of the soil linked to the formation factors (Cambardella et al., 1994).

However, the sand fraction of the forest area and the variable $\tau_{\mathrm{c} \text { wepp }}$ for brachiaria area, along with the variables silt, $\mathrm{K}$ and $\tau_{\mathrm{c} \text { wepp }}$ for mombaça grass, were shown to have a moderate spatial dependence $(26 \%<\mathrm{DSD}<75 \%)$. For the other variables, a strong degree of spatial dependence was found.

The semivariograms were adjusted to the exponential model for all areas studied except for the attribute OM, which presented the spherical model for brachiaria, mombaça and forest area (Figures 4, 5 and 6), and for the sand of the brachiaria area which best fit the Gaussian model (Figure 5). The choice of models was evaluated using the highest $\mathrm{R}^{2}$ value, corroborating with Faraco et al. (2008), in which they evaluated the exponential model for most variables, followed by the spherical and Gaussian model and excluding those that presented a pure nugget effect (PNE).

According to Isaaks and Srivastava (1989), spherical models describe soil properties with high spatial continuity, that is, less erratic over short distances. Studies by Aquino et al. (2015), evaluating forest and pasture areas, observed that the spherical and exponential models were also the ones that best fit for physical soil attributes.

Carvalho et al. (2010), in a study about spatial variability of the physical and chemical attributes of the soil, mention that the $\mathrm{R}^{2}$ and cross-validation are tools designed to evaluate alternative models of semivariograms that will perform kriging to predict values in places unsampled and to optimize sampling loops. The lowest values of the $\mathrm{R}^{2}$ obtained were found in factor $\mathrm{K}$ and $\mathrm{OM}$ in the three areas. But in general the values were high, allowing us to obtain maps of the spatial distribution of the attributes with quality.

Kriging maps allow the establishment of land-use and management criteria in isolation for each variable evaluated, making it possible to improve the use of the area, the nutrition of pastures (Alencar et al., 2016), with decreased production costs and quick and certain decision making, enabling greater productivity and also the conservation of the environment through less use of pesticides, in addition to providing more detailed and useful records of the productive area (Santos et al., 2017).

The K factor kriging maps showed smaller and uniform scores, indicating that soil losses, in general, occur more uniformly. Thus, the maps of the spatial distribution of the physical attributes are presented in Figures 7, 8 and 9, which allowed a greater understanding of the distribution of the analyzed areas. In this way, the study of the spatial distribution of the physical properties of the soil can be used to select indicators of groundwater storage and flow potential (Alvarenga et al., 2012) and to identify degraded pasture regions (Grego et al., 2012).

Through maps it is possible to observe spatial correlations between attributes, mainly those related to compaction. In general, it is possible to verify which attributes are most influenced by the relief. It is observed that the variables related to the texture suffer more changes due to the relief, that is, this occurs due to the microreliefs present in the areas, which condition the different flows of water and the soil particles from the highest parts to the lowest with it (Oliveira et al., 2013).

Burak et al. (2012) proved that the higher the PCA scores, the greater their contribution to 
positive correlations between the variables that make up each factor. In contrast, the $\mathrm{K}$ factor had lower scores, so the lower the scores, the greater the contribution to negative correlations.

The forest area showed most of the positive scores, while the pasture areas showed the most negative. According to Ribas and Vieira (2011), the objective of principal component analysis (PCA) is achieved when a relatively small number of extracted components have the ability to explain most of the variability in the original data. It allows us to qualitatively evaluate at the same time the interactions between the attributes of the soil. In general, these attribute values were normalized to the mean equal to zero (0) and the variance equal to one (1).

In detail, the first component explained $61.26 \%$ of the total variability of the data; such a component presented a percentage of explanation for attributes more focused on soil granulometric characteristics such as: sand, clay, $K_{i \text { wepp }}$ and $\tau_{\mathrm{c} \text { wepp. }}$. It was also observed that only clay, OM, K and $\tau_{\mathrm{c} \text { wepp }}$ correlated positively (Table 3 , Figure 10 ).

The mombaça grass area functions as an intermediate environment between the forest and the brachiaria, being closer to the forest environment (Figure 10). Thus, PC2 shows that brachiaria is discriminated by the highest sand content, and PC1 by $\mathrm{K}_{\mathrm{i} \text { wepp }}$. However, the area with mombaça grass showed intermediate levels in relation to the areas studied. In general, it was possible to attribute the highest levels of sand and the lowest levels of silt and clay in the pasture areas in relation to the forest, the greater intensity of removal of fine particles provided by the micro reliefs, and according to Oliveira et al. (2013), also to the conditioning of water flows (Oliveira et al., 2013), which are intensified by the low ground cover provided by pastures (Santos et al., 2018).

The second PC had an explanation percentage of $18.24 \%$ of the data variability, with characteristics more related to the condition of $\mathrm{OM}$ and factor $\mathrm{K}$ of the soil, and both attributes showed a positive correlation (Table 3 ). However, studies that address the soil organic matter fractions and their direct link to the $\mathrm{K}$ factor are still needed to understand why these two variables have a direct dependence relationship. In general, both PCs retained a percentage of the explained variance of $79.50 \%$ (Table 3 and Figure 10).

However, it was observed that all quadrants in each environment need differentiated management, more or less intensive, and thereby increase the efficiency of the use of natural resources, reducing the impact of agriculture on the environment and optimizing the economic costs for the agricultural system (Santos et al., 2017). Couto et al. (2016), evaluating through MANOVA different environments in the southwestern Amazon, observed that the pasture and forest environment do not differ statistically, corroborating the results found here. Oliveira $e t$ al. (2015b), evaluating soils under different uses in the southern region of Amazonas, also verified through multivariate analysis that forest and pasture environments do not differ from each other.

However, studies are needed in other regions, mainly in Rondônia, where there is a high livestock production, as it is still possible to increase production without deforesting the areas, only improving the productivity of soils with adequate management, aiming at improving economic, social and environmental aspects.

\section{CONCLUSION}

The high spatial variability of physical attributes in the environment with mombaça grass is attributed to the greater intensity of grazing and animal trampling.

The forest area represents most of the positive scores obtained in the principal component analysis, while the pasture areas the majority of the negative scores, indicating that the OM in the forest is correlated with the acidity components, differently from the correlations found for the pastures.

The $\mathrm{K}$ factor presented low variability for pasture area compared to forest area, indicating a good homogeneity of the area in addition to a good representativeness of the samplings carried 
out.

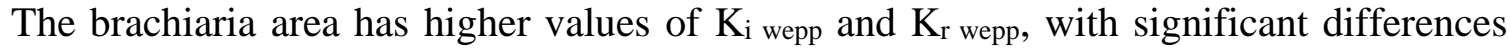
between the other areas. However, the forest and pasture environments differed in terms of soil erodibility, where the area with mombaça grass was intermediate between brachiaria and forest.

\section{REFERENCES}

ADAMY, A. (org.). Geodiversidade do estado de Rondônia. São Paulo: CPRM, 2010. 337 p.

ALENCAR, N. M.; MELO J. C.; SANTOS, A. C.; CUNHA, O. F. R.; PAULA NETO, J. J. Distribuição espacial das propriedades do solo, produção do capim-marandu com a intensidade de pastejo. Revista Engenharia na Agricultura-Reveng, v. 24, n. 4, p. 338349, 2016. https://doi.org/10.13083/reveng.v24i4.602

ALHO, L. C.; CAMPOS, M. C. C.; MANTOVANELli, B. C.; SILVA, D. M. P.; SOUZA, Z. M.; CUNHA, J. M. et al. Physical and geospatial attributes of inceptisols and ultisols under native vegetation in Humaitá, AM, Brazil. Bioscience Journal, v. 32, n. 2, p. 422 430, 2016.

AlvarenGA, C. C.; MEllo, C. R. D.; Mello, J. M. D.; SILVA, A. M. D.; CURI, N. Índice de qualidade do solo associado à recarga de água subterrânea (IQSRA) na bacia hidrográfica do Alto Rio Grande, MG. Revista Brasileira de Ciência do Solo, v. 36, n. 5, p. 1608-1619, 2012. https://doi.org/10.1590/S0100-06832012000500025

ALVARES, C. A.; STAPE, J. L.; SENTELHAS, P. C.; GONÇALVES, J. L. M.; SPAROVEK, G. Köppen's climate classification map for Brazil. Meteorologische Zeitschrift, v. 22, n. 6, p. 711-728, 2013. https://dx.doi.org/10.1127/0941-2948/2013/0507

AMORIM, R. S. S.; SILVA, D. D.; PRUSKI, F. F.; MATOS, A. T. Avaliação do desempenho dos modelos de predição da erosão hídrica USLE, RUSLE e WEPP para diferentes condições edafoclimáticas do Brasil. Engenharia Agrícola, v. 30, n. 6, p. 1046-1049, 2010. https://doi.org/10.1590/S0100-69162010000600006

AQUINO, R. E.; CAMPOS, M. C. C.; MARQUES JUNIOR, J.; OLIVEIRA, I. A.; TEIXEIRA, D. D. B.; CUNHA, J. M. Use of scaled semivariograms in the planning sample of soil physical properties in southern Amazonas, Brazil. Revista Brasileira de Ciência do Solo, v. 39, n. 1, p. 21-30, 2015. https://doi.org/10.1590/01000683rbcs20150524

ARTUR, A. G.; OLIVEIRA, D. P.; COSTA, M. C.; ROMERO, R. E.; SILVA, M. V.; FERREIRA, T. O. Variabilidade espacial dos atributos químicos do solo, associada ao microrrelevo. Revista Brasileira de Engenharia Agrícola e Ambiental, v. 18, n. 2, p. 141-149, 2014. https://doi.org/10.1590/S1415-43662014000200003

ASSUNÇÃO, S. A.; PEREIRA, M. G.; ROSSET, J. S.; BERBARA, R. L. L.; GARCÍA, A. C. Carbon input and the structural quality of soil organic matter as a function of agricultural management in a tropical climate region of Brazil. Science of the Total Environment, v. 658, p. 901-911, 2019. https://doi.org/10.1016/j.scitotenv.2018.12.271

AZEVEDO, E. C. Uso da Geoestatística e de recursos de geoprocessamento no diagnóstico da degradação de um solo argiloso sob pastagem no estado de Mato Grosso. 2004. 141f. Tese (Doutorado) - Faculdade de Engenharia Agrícola Universidade Estadual de Campinas, Campinas, 2004. 
BERTOL, I.; COGO, N. P.; SCHICK, J.; GUDAGNIN, J. C.; AMARAL, A. J. Aspectos financeiros relacionados às perdas de nutrientes por erosão hídrica em diferentes sistemas de manejo do solo. Revista Brasileira de Ciência do Solo, v. 31, n. 1, p. 133-142, 2007.

BERTONI, J.; LOMBARDI NETO, F. Conservação do Solo. São Paulo: Ícone, v. 4, 1999.

BURAK, D. L.; PASSOS, R. R.; ANDRADE, F. V. Variabilidade espacial de atributos químicos do solo sob cafeeiro Conilon: relação com textura, matéria orgânica e relevo. Bragantia, v. 71, n. 4, p. 538-547, 2012. https://doi.org/10.1590/S000687052012000400012

BURAK, D. L.; PASSOS, R. R.; SARNAGLIA, S. A. Utilização da análise multivariada na avaliação de parâmetros geomorfológicos e atributos físicos do solo. Enciclopédia Biosfera, v. 6, n. 9, p. 1-11, 2010.

CAMBARDELLA, C. A.; MOORMAN, T. B.; NOVAK, J. M.; PARKIN, T. B.; KARLEN, D. L.; TURCO, R. F. et al. Field-scale variability of soil properties in Central Iowa. Soil Science Society of America Journal, v. 58, p. 1501-11, 1994. https://doi.org/10.2136/sssaj1994.03615995005800050033x

CAMPOS, M. C. C.; MARQUES JÚNIOR, J. ; MARTINS FILHO, M. V. ; PEREIRA, G. T. ; SOUZA, Z. M.; BARBIERI, D. M. Variação espacial da perda de solo por erosão em diferentes superfícies geomórficas. Ciência Rural, v. 38, n. 9, p. 2485-2492, 2008. https://doi.org/10.1590/S0103-84782008000900011

CARVALHO, S. R. L.; VILAS BOAS, G. S.; FADIGAS, F. S. Variabilidade espacial de atributos físicos e químicos em solos originados nos sedimentos da formação barreiras. Cadernos de Geociências, v. 7, n. 2, 2010.

CASTRO, W. J.; LEMKE-DE-CASTRO, M. L.; LIMA, J. O.; OLIVEIRA, F. C.; RODRIGUES, C.; FIGUEIREDO, C. C. Erodibilidade de solos do cerrado goiano. Revista em Agronegócios e Meio Ambiente, v. 4, n. 2, p. 305-320, 2011. https://doi.org/10.17765/2176-9168.2011v4n2p\%25p

CAVAlCANTE, E. G. S.; ALVES, M. C.; SOUZA, Z. M.; PEREIRA, G.T. Variabilidade espacial de atributos físicos do solo sob diferentes usos e manejos. Revista Brasileira de Engenharia Agrícola Ambiental, v. 15, n. 3, p. 237-243, 2011. https://doi.org/10.1590/S1415-43662011000300003

CEDDIA, M. B.; VIEIRA, S. R.; VILLELA, A. L. O.; MOTA, L. S.; ANJOS, L. H. C.; CARVALHO, D. F. Topography and spatial variability of soil physical properties. Scientia Agricola, v. 66, p. 338-352, 2009. https://doi.org/10.1590/S010390162009000300009

CORTEZ, J. W. ALVES, A. D. S.; MOURA, M. R. D.; OLSZEVSKI, N.; NAGAHAMA, H. J. Atributos físicos do Argissolo Amarelo do semiárido nordestino sob sistemas de preparo. Revista Brasileira de Ciência do Solo, v. 35, n. 4, p. 1207-1216, 2011.

COUTO, W. H.; ANJOS, L. H. C.; WADT, P. G. S.; PEREIRA, M. G. Atributos edáficos e resistência a penetração em áreas de sistemas agroflorestais no sudoeste amazônico. Ciência Florestal, v. 26, n. 3, p. 811-823, 2016. https://doi.org/10.5902/1980509824210

CUNHA, J. M.; GAIO, D. C.; CAMPOS, M. C. C.; SOARES, M. D. R; SILVA, D. M. P; LIMA, A. F. L. Atributos físicos e estoque de carbono do solo em áreas de Terra Preta Arqueológica da Amazônia. Revista Ambiente \& Água, v. 12, n. 2, p. 263-281, 2017. https://doi.org/10.4136/ambi-agua. 1890 
DALCHIAVON, F. C.; CARVALHO, M. P.; ANDREOTTI, M.; MONTANARI, R. Variabilidade espacial de atributos da fertilidade de um Latossolo Vermelho Distroférrico sob sistema plantio direto. Revista Ciência Agronômica, v. 43, n. 3, p. 453-461, 2012.

DEMARCHI, J. C.; PIROLI, E. L.; ZIMBACK, C. R. L. Estimativa de perda de solos por erosão na bacia hidrográfica do Ribeirão das Perobas (SP) nos anos 1962 e 2011. Raega - O Espaço Geográfico em Análise, v. 46, n. 1, p. 110-131, 2019. http://dx.doi.org/10.5380/raega.v46i1.56746

DENARDIN, J. E. Erodibilidade de solo estimada por meio de parâmetros físicos e químicos. Tese (Doutorado) - Escola Superior de Agricultura Luiz de Queiroz, p. 113, 1990.

DIAS, F. P. M.; HÜBNER, R.; NUNES, F. J.; LEANDRO, W. M.; XAVIER. F. A. S. Effects of land-use change on chemical attributes of a Ferralsol in Brazilian Cerrado. Catena, v. 177, p. 180-188, 2019. https://doi.org/10.1016/j.catena.2019.02.016

FARACO, M. A.; URIBE-OPAZO, M. A.; SILVA, E. A. A.; JOHANN, J. A.; BORSSOI, J. A. Seleção de modelos de variabilidade espacial para elaboração de mapas temáticos de atributos físicos do solo e produtividade da soja. Revista Brasileira de Ciência do Solo, v. 32, n. 2, p. 463-476, 2008.

FLANAGAN, D. C.; LIVINGSTON, S. J. (eds.). USDA - Water erosion prediction project: WEEP user summary. West Lafayette: National Soil Research Laboratory \& USDA, 1995. p. 25-26.

FRANZLUEBBERS, A. J.; STUEDEMANN, J. A.; FRANKLIN, D. H. Water infiltration and surface-soil structural properties as influenced by animal traffic in the Southern Piedmont USA. Renewable Agriculture and Food Systems, v. 27, p. 256-265, 2011. https://doi.org/10.1017/S1742170511000378

FROGBROOK, Z. L.; OLIVER, M. A.; SALAHI, M.; ELLIS, R. H. Exploring the spatial relations between cereal yield and soil chemical properties and the implications for sampling. Soil Use and Management, v. 18, n. 1, p. 1-9, 2002. https://doi.org/10.1111/j.1475-2743.2002.tb00043.x

GOLDEN SOFTWARE INC. Surfer for Windows, Release 13.0: Contouring and 3D surface mapping for scientist's engineers, user's guide. 1999.

GUIMARÃES, E. C. Variabilidade espacial da umidade e da densidade do solo em um Latossolo Roxo. 1993. 57f. Dissertação (Mestrado) - Campinas: Universidade de Campinas. 1993.

GREGO, C. R.; RODRIGUES, C. A. G.; NOGUEIRA, S. F.; GIMENES, F. M. A.; OLIVEIRA, A. D.; ALMEIDA, C. G. F. D. et al. Variabilidade espacial do solo e da biomassa epígea de pastagem, identificada por meio de geoestatística. Pesquisa Agropecuária Brasileira, v. 47, n. 9, p. 1404-1412, 2012. https://doi.org/10.1590/S0100-204X2012000900026

KAMIMURA, K. M., SANTOS, G. R. D., OLIVEIRA, M. S. D., DIAS JUNIOR, M. D. S., \& GUIMARÃES, P. T. G. Variabilidade espacial de atributos físicos de um Latossolo Vermelho-Amarelo, sob lavoura cafeeira. Revista Brasileira de Ciência do Solo, v. 37 , n. 2, p. 877-88, 2013.

IBGE. Mapa de Vegetação do Brasil. Escala: 1:5,000,000. Instituto Brasileiro de Geografia e Estatística - IBGE. 2004. 
IBM. SPSS Statistics 21.0. 2017.

ISAAKS, E. H.; SRIVASTAVA, R. M. An introduction to applied geostatistics. Oxford: Oxford University Press, 1989.

MACEDO, R. S.; TEIXEIRA, W. G.; ENCINAS, O. C.; SOUZA, A. C. G.; MARTINS, G. C.; ROSSI, L. M. B. Determinação do fator erodibilidade de diferentes classes de solo do estado do Amazonas (métodos indiretos) e de um Cambissolo Háplico (método direto) na Província Petrolífera de Urucu, Coari - AM. In: REUNIÃO CIENTIFICA DA REDE CTPETRO AMAZÔNIA, 3., 4 a 5de nov. 2010, Manaus. Anais[...] Brasília: Embrapa, 2010.

MARQUES, J. J. G. S. M.; CURI, N.; LIMA, J. M.; FERREIRA, M. M.; SILVA, M. L. N.; FERREIRA, D. F. Estimativa da erodibilidade a partir de atributos de solos com horizonte B textural no Brasil. Revista Brasileira de Ciência do Solo, v. 21, p. 457-465, 1997.

MINGOTI, S. A. Análise de dados através de métodos de estatística multivariada. Belo Horizonte: UFMG, 2007. 295 p.

MORGAN, R. P. C. Soil Erosion and Conservation. Essex: Longman; 3, 1995.

NEGREIROS NETO, J. V.; SANTOS, A. C.; GUARNIERI, A.; SOUZA, D. J. A. T.; DARONCH, D. J.; DOTTO, M. A. et al. Variabilidade espacial de atributos físicoquímicos de um Latossolo Vermelho-Amarelo distrófico em sistema plantio direto. Semina: Ciências Agrárias, v. 35, n. 1, p. 193-204, 2014. https://dx.doi.org/10.5433/1679-0359.2014v35n1p193

NUNES, J. G.; CAMPOS, M. C. C.; NUNES, J. C.; MANTOVANELLI, B. C.; CUNHA, J.M.; SOARES, M. D. R. Aplicação da equação universal de perdas de solo na região sul do Amazonas. Revista da Universidade Vale do Rio Verde, v. 15, n. 2, p. 548-557, 2017. http://dx.doi.org/10.5892/ruvrd.v15i2.2991

OLIVEIRA, I. A.; MARQUES JUNIOR, J.; CAMPOS, M. C. C.; AQUINO, R. E.; FREITAS, L. D.; SIQUEIRA, D. S. et al. Variabilidade espacial e densidade amostral da suscetibilidade magnética e dos atributos de Argissolos da Região de Manicoré, AM. Revista Brasileira de Ciência do Solo, v. 39, n. 3, p. 668-681, 2015a. https://doi.org/10.1590/01000683rbcs20140496

OLIVEIRA, I. A.; CAMPOS, M. C. C.; MARQUES JUNIOR, J.; AQUINO, R. E.; TEIXEIRA, D. D. B.; SILVA, D. M. P. Use of scaled semivariograms in the planning sample of soil chemical properties in Southern Amazonas, Brazil. Revista Brasileira de Ciência do Solo, v. 39, n. 1, p. 31-39, 2015b. https://doi.org/10.1590/01000683rbcs20150525

OLIVEIRA, D. P.; FERREIRA, T. O.; ROMERO, R. E.; FARIAS, P. R. S.; COSTA, M. C. G. Microrrelevo e a distribuição de frações granulométricas em Cambissolos de origem calcária. Revista Ciência Agronômica, v. 44, n. 4, p. 676-684, 2013. https://doi.org/10.1590/S1806-66902013000400003

PERIGOLO, N. A.; MEDEIROS, M. B.; SIMON, M. F. Vegetation types of the upper Madeira River in Rondônia, Brazil. Brittonia, v. 69, n. 4, p. 423-446, 2017. https://doi.org/10.1007/s12228-017-9505-1

RIBAS, J. R.; VIEIRA, P. R. C. Análise Multivariada com o uso do SPSS. São Paulo: Ciência Moderna, 2011. 272 p. 
ROBERTSON, G. P. GS ${ }^{+}$: Geostatistics for the environmental sciences - GS ${ }^{+}$User's Guide. Plainwell: Gamma Design Software. 2004. 152 p.

SÁ, M. A. C.; LIMA, J. M.; CURI, N.; MASSAROTO, J. A.; SÁ, J. J. G.; MARQUES. M. Estimativa da erodibilidade pela desagregação por ultra - som e atributos de solos com horizonte B textural. Pesquisa Agropecuária Brasileira, v. 39, n. 7, p. 691-699, 2004. https://doi.org/10.1590/S0100-204X2004000700011

SANTOS, K. E. L.; BERNARDI, A. D. C.; BETTIOL, G. M.; CRESTANA, S. Geoestatística e geoprocessamento na tomada de decisão do uso de insumos em uma pastagem. Brazilian Journal of Biosystems Engineering, v. 11, n. 3, p. 294-307, 2017.

SANTOS, E. A. N.; CAMPOS, M. C. C.; CUNHA, J. M.; SOUZA, F. G.; WADT; P. G. S.; PINHEIRO, E. N.; Freitas, L. Gypsum, soil scarification and succession planting as alternatives to mitigate compaction of dystrophic Red-Yellow Latosol. Journal of $\begin{array}{llllllll}\text { Agricultural } & \text { Science, } & \text { v. } & 10, & \text { n. } & 8, & \text { p. } & \text { 277-285, }\end{array}$ https://doi.org/10.5539/jas.v10n8p277

SENA, M. M.; FRIGHETTO, R. T. S.; VALARINI, P. J.; TOKESHI, H.; POPPI, R. J. Discrimination of management effects on soil parameters by using principal component analysis: a multivariate analysis case study. Soil \& Tillage Research, v. 67, p. 171-181, 2002. https://doi.org/10.1016/S0167-1987(02)00063-6

SILVA, M. O.; FREIRE, M. B. G. S.; MENDES, A. M. S.; FREIRE, F. J.; CAMPOS, M. C. C.; AMORIM, L. B. Discriminação de diferentes classes de solos irrigados com águas salinas, na região de Mossoró, RN, com o uso de análise multivariada. Ambiência, v. 6, n. 2, p. 261-270, 2010.

SILVA NETO, S. P.; SANTOS, A. C.; LIMA LEITE, R. L.; DIM, V. P.; NEVES NETO, D. N.; SILVA, J. E. C. Variação espacial do teor de matéria orgânica do solo e produção de gramínea em pastagens de capim-marandu. Bioscience Journal, v. 28, n. 1, p. 41-53, 2012.

SOARES, M. D. R.; CAMPOS, M. C. C.; OLIVEIRA, I. A.; CUNHA, J. M.; SANTOS, L. A. C.; FONSECA, J. S. et al. Atributos físicos do solo em áreas sob diferentes sistemas de usos na região de Manicoré, AM. Revista Ciência Agraria, v. 59, n. 1, p. 9-15, 2016.

SCHLINDWEIN, J. A.; MARCOLAN, A. L.; FIORELI-PERIRA, E. C.; PEQUENO, P. L. L; MILITÃO, J. S. T. L. Solos de Rondônia: usos e perspectivas. Revista Brasileira de Ciências da Amazônia, v. 1, n. 1, p. 2013-2031, 2012.

STATSOFT INC. Statistica 7.0: data analysis software system. Tulsa, 2004.

TEIXEIRA, P. C.; DONAGEMA, G. K.; ADEMIR, F.; TEIXEIRA, W. G. Manual de métodos de análise de solo. 3. ed. Brasília: Embrapa, 2017. 573p.

WALKLEY, A.; BLACK, I. A. An examination of the degtjareff method for determining soil organic matter and a proposed modification of the chromic acid titration method. Soil Science, v. 37, n.1, p. 29-38, 1934.

WARRICK, A. W.; NIELSEN, D. R. Spatial variability of soil physical properties in the field, In: HILLEL, D. (ed.). Application of soil physics. New York: Academic Press, 1980. p. 319-344. 
WISCHMEIER, W. H.; JOHNSON, C. B.; CROSS, B. V. Soil erodibility monograph for farmland and construction sites. Journal of Soil and Water Conservation, v. 26, n. 5, p. 189-193, 1971.

YEOMANS, J. C.; BREMNER, J. M. A rapid and precise method for routine determination of organic carbon in soil. Communication in Soil Science and Plant Analysis, v. 19, n. 13, p. 1467-1476, 1988. https://doi.org/10.1080/00103628809368027

ZENERO, M. D. O.; GRIMALDIB, M.; COOPERA, M. Variability in soil shrinkage along forest and pasture toposequences in Amazonia. Geoderma, v. 338, p. 291-301, 2019. https://doi.org/10.1016/j.geoderma.2018.12.013 


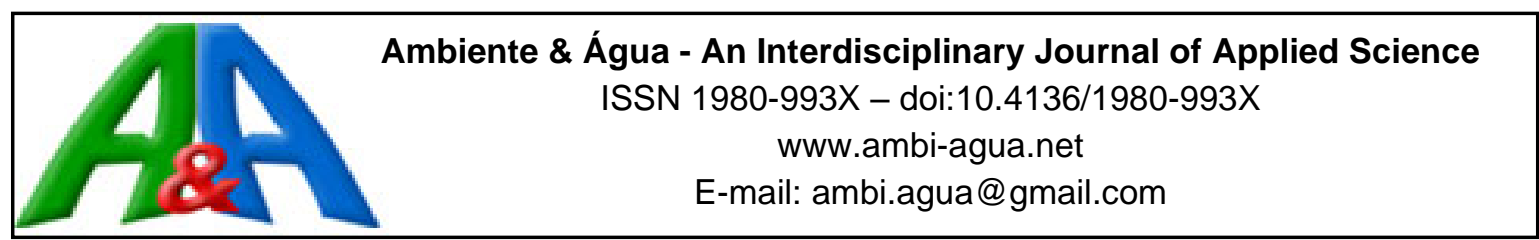

\title{
Effect of turbidity on ultraviolet disinfection of domestic wastewater for agricultural reuse
}

\author{
ARTICLES doi:10.4136/ambi-agua.2766
}

Received: 05 Jul. 2021; Accepted: 10 Nov. 2021

\section{Diego Fernando Atoche Garay ${ }^{10}$; Lisiana Crivelenti Voltolini ${ }^{\circledR D}$; Reinaldo Gaspar Bastos ${ }^{3}$; Claudinei Fonseca Souza ${ }^{1 * i 0}$}

\author{
${ }^{1}$ Centro de Ciências Agrárias. Departamento de Recursos Naturais e Proteção Ambiental. Universidade Federal \\ de São Carlos (UFSCar), Via Anhanguera, km 174, CEP: 13600-970, Araras, SP, Brazil. \\ E-mail: diegosatoche@hotmail.com \\ ${ }^{2}$ Centro de Ciências Agrárias. Programa de Pós-Graduação em Agricultura e Ambiente. Universidade Federal de \\ São Carlos (UFSCar), Via Anhanguera, km 174, CEP: 13600-970, Araras, SP, Brazil. \\ E-mail: lisianacrivelenti@yahoo.com.br \\ ${ }^{3}$ Centro de Ciências Agrárias. Departamento de Tecnologia Agroindustrial e Socioeconomia Rural. \\ Universidade Federal de São Carlos (UFSCar), Via Anhanguera, km 174, CEP: 13600-970, Araras, SP, Brazil. \\ E-mail: reinaldo.bastos@ufscar.br \\ *Corresponding author. E-mail: cfsouza@ufscar.br
}

\begin{abstract}
Water treatment and reuse are fundamental because of the increasing demand for freshwater, especially in agriculture. Accordingly, this study evaluated the effects of turbidity of wastewater processed at the Effluent Treatment Station (ETE) of the UFSCar/Araras and of UV dose on microbial inactivation. The ETE treats up to $2000 \mathrm{~L}$ of wastewater daily from toilets and a university restaurant and has five components (grease box, septic tank, microalgae tank, upflow anaerobic filter, and wetlands). Pretreated effluents were used in the experiments, and sampling sites consisted of inspection boxes located after the wetlands. Sample collection, inspection, preservation, and analyses were performed according to standard methods. Sample turbidity was adjusted to 5, 50, 100, 200, and 300 nephelometric turbidity units (NTU), and UV doses of 7.2-28.8 $\mathrm{mWs} \mathrm{cm}^{-2}$ were used. A 5 x 5 factorial design (five turbidity levels and five radiation doses) was used, totaling 25 treatments. Each treatment was performed in triplicate. The data were submitted to analysis of variance and Tukey's test. The results showed that the increase in turbidity significantly decreased disinfection efficiency in samples with turbidity levels higher than 50 NTU. The microbial inactivation coefficients obtained here can be extrapolated to disinfection of wastewater with turbidity up to 300 NTU to eliminate thermotolerant coliforms. The UV sterilizer is feasible for wastewater treatment and its reuse in agriculture.
\end{abstract}

Keywords: domestic effluent, sustainability, ultraviolet radiation, water reuse.

\section{Efeito da turbidez na desinfecção ultravioleta de águas residuais domésticas para reutilização agrícola}

\section{RESUMO}

O tratamento e o reúso da água são fundamentais devido à crescente demanda por água doce, principalmente na agricultura. Nesse sentido, este estudo teve como objetivo avaliar os 
efeitos da turbidez de águas residuárias tratada na Estação de Tratamento de Efluentes (ETE) da UFSCar/Araras e da dose de UV na inativação microbiana. A ETE trata até 2.000 litros de águas residuais diariamente de banheiros e um restaurante universitário e tem cinco componentes (caixa de graxa, fossa séptica, tanque de microalgas, filtro anaeróbio de fluxo ascendente e wetlands). Efluentes pré-tratados foram usados nos experimentos, e os locais de amostragem consistiram em caixas de inspeção localizadas após os wetlands. A coleta de amostras, inspeção, preservação e análises foram realizadas de acordo com métodos padrão. A turbidez da amostra foi ajustada para 5, 50,100, 200 e 300 unidades de turbidez nefelométrica (NTU) e doses de UV de 7,2-28,8 $\mathrm{mWs}^{-2}$ foram usadas. Foi utilizado um planejamento fatorial 5 x 5 (cinco níveis de turbidez e cinco doses de radiação), totalizando 25 tratamentos. Cada tratamento foi realizado em triplicata. Os dados foram submetidos à análise de variância e teste de Tukey. Os resultados mostraram que o aumento da turbidez diminuiu significativamente a eficiência da desinfecção em amostras com níveis de turbidez superiores a 50 NTU. Os coeficientes de inativação microbiana aqui obtidos podem ser extrapolados para a desinfecção de águas residuais com turbidez de até 300 NTU para eliminar coliformes termotolerantes. O esterilizador UV é viável para o tratamento de efluentes e sua reutilização na agricultura.

Palavras-chave: efluente doméstico, radiação ultravioleta, reúso de água, sustentabilidade.

\section{INTRODUCTION}

Increases in world population, urbanization, and water use for irrigation have led to irregular and disordered water supply, hence limiting water availability. This has promoted indirect reuse of wastewater without prior planning or treatment (Oliveira et al., 2019). However, after proper treatments, the reuse of effluents is an alternative to meet water demands of the agricultural sector, in which large amounts of freshwater are used (Zewde et al., 2019). Disinfection is considered a tertiary treatment, with emphasis on chlorination, ozonation, reverse osmosis, membrane filtration, and ultraviolet (UV) radiation (Collivignarelli et al., 2018). However, these treatments are expensive and increase the toxicity of effluents (Chai $e t$ al., 2018).

The purpose of UV sterilization is eliminating or inactivating microorganisms such as bacteria and viruses (Chhetri et al., 2018). UV radiation has been increasingly used in wastewater treatment in the last 25 years because of little contact time and high antimicrobial activity (Masschelein et al., 1989; Guo et al., 2009; Zewde et al., 2019).

UV disinfection of water and wastewater normally uses low-pressure mercury lamps at the $254 \mathrm{~nm}$ wavelength (Zewde et al., 2019). Short UV radiation (100 - $280 \mathrm{~nm}$ ) causes changes in DNA and RNA molecules, which absorb radiation at wavelengths between 200 and $300 \mathrm{~nm}$, especially at about $260 \mathrm{~nm}$. This radiation range alters the structure and function of nucleic acids, inhibiting DNA replication and inactivating microbial cells (Gibson et al., 2017). More recently, Silva et al. (2020) evaluated the inactivation of Escherichia coli in effluent from an urban wastewater treatment plant subjected to UV-LED (Ultraviolet-Light Emitting Diodes) radiation, emitting UVA (365 and $(405 \mathrm{~nm})$ or UVC $(255$ and $280 \mathrm{~nm})$. The authors indicated that $280 \mathrm{~nm}$ UV-LED appears to be crucial for the success of the disinfection process, with a 4-log reduction being obtained at this wavelength.

The advantages of UV radiation include absence of dangerous co-products or chemicals that could change water composition, in addition to short contact time and inactivation of viruses (Guo et al., 2012; Gibson et al., 2017; Bolyard et al., 2019). After UV radiation treatment, wastewater could be used in agriculture if legal requirements are met and its use does not alter microbial ecosystems in soils (Chevremont et al., 2013). 
The degree of microbial cell inactivation is directly proportional to the UV dose applied. The dose is the amount of UV light emitted by the lamp and is calculated as the radiation intensity multiplied by the duration of exposure, as well as the dose of chemical disinfectants (Gibson et al., 2017; Zewde et al., 2019). Therefore, the use of adequate doses during disinfection is essential for the complete inhibition of microbial growth.

UV radiation intensity decreases when penetrating materials due to its absorption (Artichowicz et al., 2020). Therefore, physicochemical properties of wastewater may affect UV light transmittance, and hence treatment efficiency. In this sense, the efficiency of UV radiation can be affected by water turbidity, suspended solid concentrations, microorganisms, cellular aggregates, leachate, and fluid density, thus requiring higher doses for disinfection process (Hassen et al., 2000; Brahmi et al., 2010; Uslu et al., 2015; Azimi et al., 2017; Bolyard et al., 2019). Of these, turbidity, which is determined by the presence of suspended particles that reflect or absorb radiation, strongly affect UV transmittance and hence disinfection efficiency (Nourmoradi et al., 2012); in addition, colloidal particles tend to favor microbial activity (Burch and Thomas, 1998).

The Center for Agricultural Sciences of the Federal University of São Carlos (CCAUFSCar) manages a Pilot Effluent Treatment Station (ETE), in which a UV sterilizer was used to remove microbial loads; however, the equipment has not performed steadily due to variable wastewater turbidity (Oliveira et al., 2019). Thus, in this study, we assessed at a bench scale the effect of wastewater turbidity and radiation dose on microbial inactivation using a UV sterilizer for effluent treatment.

\section{MATERIAL AND METHODS}

\subsection{Study site}

The study was conducted at the ETE of CCA-UFSCar, located in Araras, São Paulo State, Brazil. The ETE treats up to 2000 liters of wastewater daily from toilets and a university restaurant and has five components (grease box, septic tank, microalgae tank, upflow anaerobic filter, and wetlands) (Figure 1).

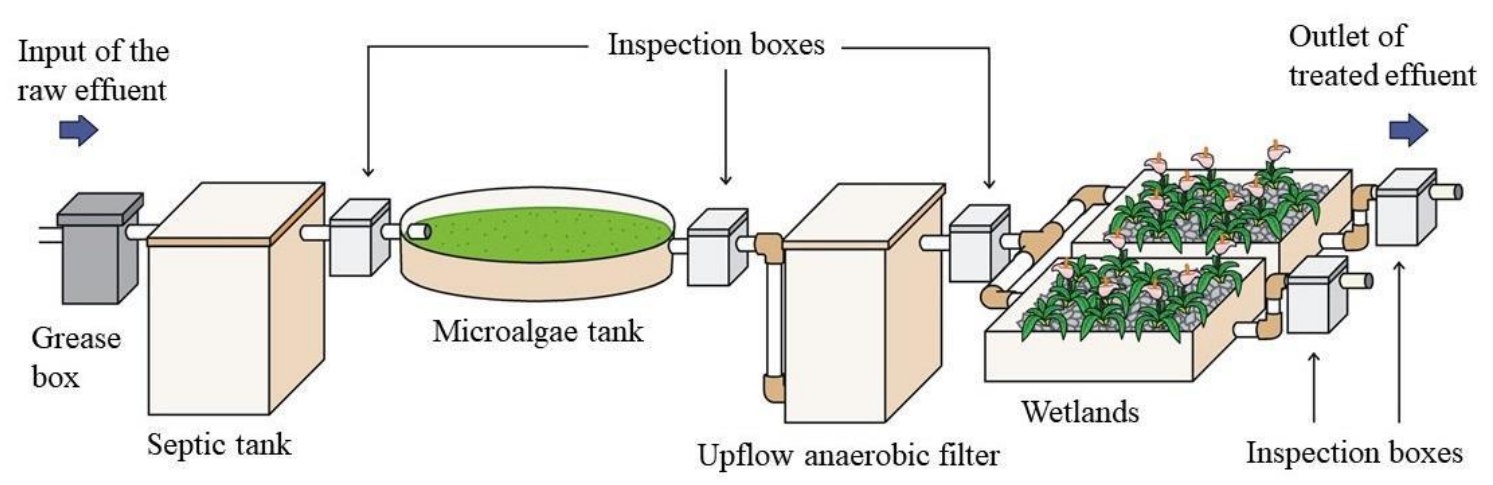

Figure 1. Schematic diagram of the effluent treatment station.

(Source: Souza et al., 2015).

\subsection{Wastewater}

Pretreated effluents were used in the experiments, and sampling sites consisted of inspection boxes located after the wetlands (Figure 1). The effluents were characterized weekly from May to June (Table 1). Sample collection, inspection, preservation, and analyses were performed according to standard methods (APHA et al., 2012).

Turbidity was adjusted to 5, 50, 100, 200, and 300 nephelometric turbidity units (NTU). Average turbidity was $20 \mathrm{NTU}$ and was normalized to 5 NTU by diluting the samples in water. To increase turbidity, a sample from the microalgae tank was centrifuged at $3000 \mathrm{rpm}$ for $5 \mathrm{~min}$ 
and resuspended to obtain a suspension with turbidity higher than $1000 \mathrm{NTU}$. Aliquots were added to diluted samples until the desired turbidity was achieved.

Table 1. Physicochemical and microbiological characteristics of wastewater.

\begin{tabular}{lc}
\hline Variable & Values \\
\hline $\mathrm{pH}$ & $7.50 \pm 0.16$ \\
Turbidity (NTU) & $20.00 \pm 12.16$ \\
$\mathrm{EC}(\mu \mathrm{S} \mathrm{cm}$ & -1 \\
$\mathrm{DO}\left(\mathrm{m} \mathrm{L} \mathrm{L}^{-1}\right)$ & $1030.00 \pm 47.36$ \\
$\mathrm{TOC}\left(\mathrm{mg} \mathrm{L}^{-1}\right)$ & $3.40 \pm 0.90$ \\
$\mathrm{TN}\left(\mathrm{mg} \mathrm{L}^{-1}\right)$ & $26.00 \pm 10.59$ \\
$\mathrm{TP}\left(\mathrm{mg} \mathrm{L}^{-1}\right)$ & $46.00 \pm 6.88$ \\
$\mathrm{TC}\left(\times 10^{6} \mathrm{MPN} 100 \mathrm{~mL}^{-1}\right)$ & $19.00 \pm 6.13$ \\
E. coli $\left(\times 10^{5} \mathrm{MPN} 100 \mathrm{~mL}^{-1}\right)$ & 5.39 \\
\hline
\end{tabular}

EC: electrical conductivity; DO: dissolved oxygen; TOC: total organic carbon; TN: total nitrogen; TP: total phosphorus; TC: total coliforms.

\subsection{Experimental procedure}

Figure 2 shows a schematic of the UV reactor used in the experiments. This reactor was built using a PVC tube and contained a UV germicidal lamp (Philips TUV 75W HO G75 T8 UV $254 \mathrm{~nm}$ ) protected by a quartz cylinder. The average radiation intensity was $0.24 \mathrm{~mW} \mathrm{~cm}^{-2}$. The water depth inside the reactor was $1 \mathrm{~cm}$.

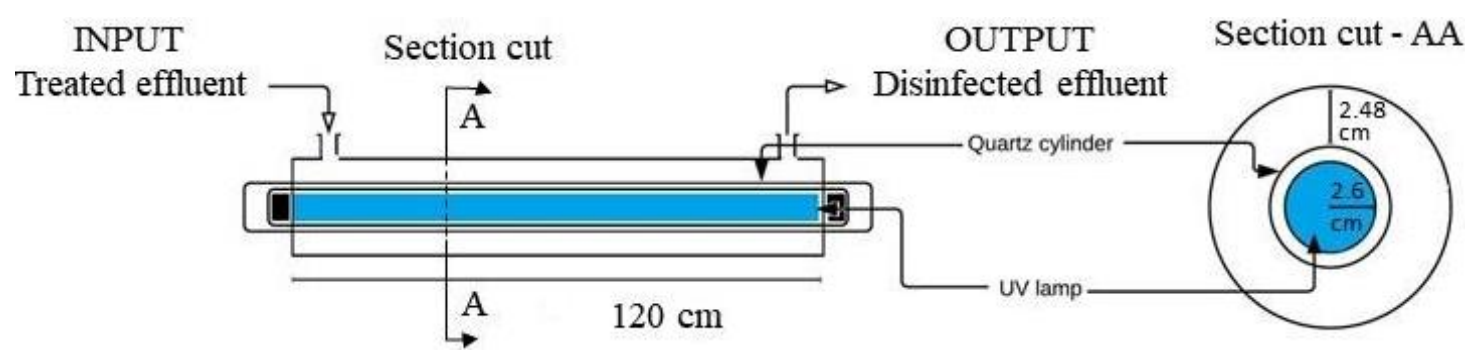

Figure 2. Diagram of the ultraviolet sterilizer.

Sterilization tests were carried out in batches by adding $1500 \mathrm{~mL}$ of a sample with known turbidity. The lamp remained on for $120 \mathrm{~s}$. Samples were collected at 0, 30, 60, 90, and $120 \mathrm{~s}$, and heterotrophic bacteria were counted. At each time point, the radiation dose was calculated by $\mathrm{D}=\mathrm{I} \times \mathrm{t}$, where $D$ is the radiation dose $(\mathrm{mWs} \mathrm{cm}), I$ is the radiation intensity $\left(\mathrm{mW} \mathrm{cm} \mathrm{cm}^{-2}\right)$, and $t$ is the duration of exposure (s) (Zewde et al., 2019). The doses used were 0.0, 7.2, 14.4, 21.6, and $28.8 \mathrm{mWs} \mathrm{cm}^{-2}$.

The collected samples were serially diluted, and $1 \mathrm{~mL}$ aliquots were transferred to $3 \mathrm{M}$ Petrifilm Aqua plates and incubated at $36 \pm 2^{\circ} \mathrm{C}$ for $44 \pm 4$ hours. Bacterial counts were expressed as colony-forming units (CFU) per mL.

A $5 \times 5$ factorial design (five turbidity levels and five radiation doses) was used, totaling 25 treatments. Each treatment was performed in triplicate. The data were submitted to analysis of variance and Tukey's test. The disinfection model was evaluated by the relationship between the logarithmic change in the number of inactivated bacterial cells and the applied dose (Zhou et al., 2016) and followed first-order Chick-Watson kinetics according to Equation 1 (Hijnen et al., 2006): 


$$
\log \left(\frac{N_{0}}{N}\right)=k * D
$$

$$
\begin{aligned}
& \mathrm{N}_{0} \text { - pre-treatment bacterial count, } \mathrm{CFU} \mathrm{mL}^{-1} \text {; } \\
& \mathrm{N} \text { - post-treatment bacterial count, } \mathrm{CFU} \mathrm{mL} \mathrm{m}^{-1} \text {; } \\
& \mathrm{k} \text { - inactivation coefficient, } \mathrm{cm}^{2} \mathrm{mWs}^{-1} \text {; } \\
& \mathrm{D} \text { - radiation dose, } \mathrm{mWs} \mathrm{cm}^{-2} \text {. }
\end{aligned}
$$

\section{RESULTS AND DISCUSSION}

The effect of turbidity was evaluated as a function of transmittance measures of samples. Transmittance is the amount of radiation passing through a sample relative to the emitted radiation. The lower the transmittance, the greater the amount of particles impairing disinfection (Nguyen et al., 2019). Transmittance decreased as turbidity increased (Figure 3).

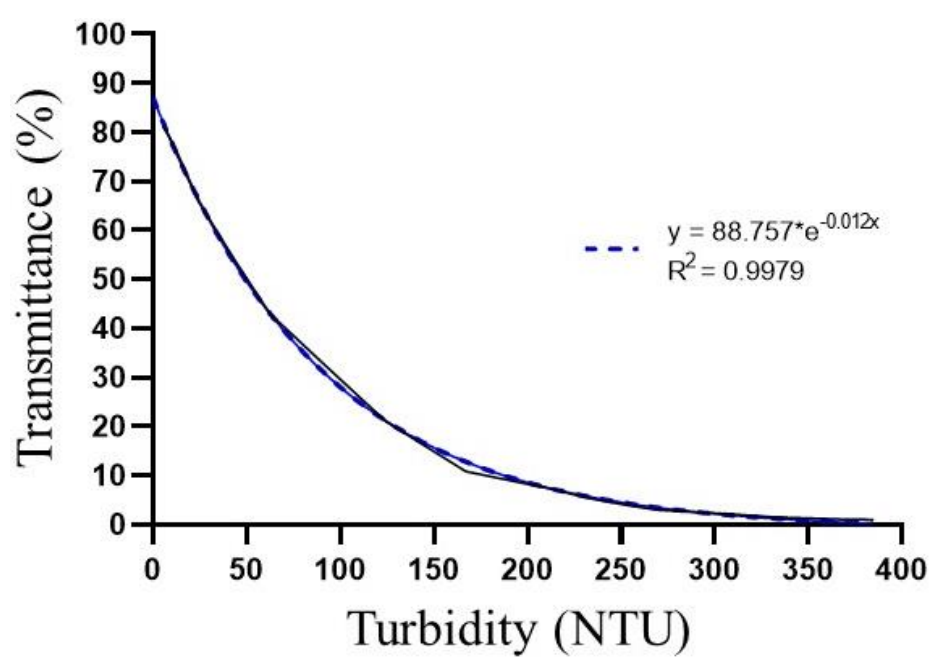

Figure 3. Transmittance profile as a function of turbidity.

The samples with a turbidity of 5, 50, 100, 200, and 300 NTU showed an approximate transmittance of $84 \%, 49 \%, 27 \%, 8 \%$, and $2 \%$, respectively. Figure 2 shows that UV transmittance decreased exponentially with turbidity; therefore, transmittance differences between samples with 5 and 50 NTU were greater than those of samples with 200 and 300 NTU. Similar results were obtained by Nguyen et al. (2019), wherein treatments that reduced effluent turbidity increased UV transmittance.

The dose of radiation absorbed by microorganisms is hard to be measured and varies with emitted light and period of exposure (Gayan et al., 2011). Given that decimal reduction times are longer (lower microbial inactivation) for heterotrophic bacteria in treated effluents, it is possible to estimate the duration of exposure for samples with turbidity levels of up to 300 NTU. Failly (1994) recommended a minimum dose of $30 \mathrm{mWs} \mathrm{cm}{ }^{-2}$ for wastewater, although the dose depends on the type of installation and the physicochemical characteristics of the effluent (Hassen et al., 2000).

Turbidity may increase or transmittance decrease with the addition of several compounds (Bolyard et al., 2019; Azimi et al., 2012; Carré et al., 2018). Depending on the material used, the efficiency of UV disinfection in inactivating microorganisms varies (Farrell et al., 2018). For instance, ultrasound treatment did not decrease effluent turbidity but increased the efficiency of UV disinfection (Zhou et al., 2016).

Microbial aggregates are formed during biological or secondary treatments through 
incorporation or adsorption of microorganisms to suspended particles. These aggregates help protect microorganisms against UV radiation and decrease disinfection efficiency (Azimi et al., 2017). Therefore, the use of a microalgae suspension to increase turbidity may have decreased the efficiency of disinfection by decreasing transmittance and promoting the formation of bacterial aggregates.

To evaluate the effect of turbidity and radiation dose on disinfection, doses of $0,7.2,14.4$, 21.6, and $28.8 \mathrm{mWs} \mathrm{cm}^{-2}$ were applied for $30,60,90$, and $120 \mathrm{~s}$, respectively, for effluents with a turbidity of 5, 50,100, 200, and 300 NTU. The results showed that the samples with a turbidity of 5 and 50 NTU presented the highest levels of disinfection. Inactivation was higher than $99.97 \%$ for all turbidity levels at a dose of $28.8 \mathrm{mWs} \mathrm{cm}^{-2}$. These results agree with those of USEPA (2006), which indicated that the dose required for killing $99.99 \%$ of coliforms in wastewater was at least $20 \mathrm{mWs} \mathrm{cm}^{-2}$.

The analysis of variance showed significant differences due to interaction between factors $(\mathrm{p}<0.05)$. Therefore, the efficiency of disinfection was analyzed according to turbidity levels and radiation doses (Table 2). All turbidity levels tested showed significant disinfection efficiency differences among radiation doses. The analysis also proved that $95 \%$ of the variation was caused by radiation doses. Thus, dose variations had a greater impact on bacterial inactivation than did turbidity changes, which agrees with a previous study (Farrell et al., 2018).

Table 2. Log-cycle reduction for the inactivation of heterotrophic bacteria as a function of the duration of exposure, radiation dose, and sample turbidity.

\begin{tabular}{|c|c|c|c|c|c|c|}
\hline \multirow{3}{*}{$\begin{array}{l}\text { Duration of } \\
\text { exposure (s) }\end{array}$} & \multirow{3}{*}{$\begin{array}{l}\text { Radiation dose } \\
\left(\mathrm{mWs} \mathrm{cm}{ }^{-2}\right)\end{array}$} & \multicolumn{5}{|c|}{ Turbidity (NTU) } \\
\hline & & 5 & 50 & 100 & 200 & 300 \\
\hline & & \multicolumn{5}{|c|}{ Log-cycle reduction } \\
\hline $0 \mathrm{~s}$ & 0 & $0.00 \mathrm{Aa}$ & $0.00 \mathrm{Aa}$ & $0.00 \mathrm{Aa}$ & $0.00 \mathrm{Aa}$ & $0.00 \mathrm{Aa}$ \\
\hline $30 \mathrm{~s}$ & 7.2 & $1.56 \mathrm{Ba}$ & 1.40 Bab & $1.18 \mathrm{Bbc}$ & $0.99 \mathrm{Bcd}$ & $0.84 \mathrm{Bd}$ \\
\hline $60 \mathrm{~s}$ & 14.4 & $2.62 \mathrm{Ca}$ & $2.64 \mathrm{Ca}$ & $2.26 \mathrm{Cb}$ & $1.96 \mathrm{Cc}$ & $1.88 \mathrm{Cc}$ \\
\hline $90 \mathrm{~s}$ & 21.6 & $3.59 \mathrm{Da}$ & $3.74 \mathrm{Da}$ & $3.29 \mathrm{Db}$ & $2.97 \mathrm{Dc}$ & $2.81 \mathrm{Dc}$ \\
\hline $120 \mathrm{~s}$ & 28.8 & $5.11 \mathrm{Ea}$ & $4.88 \mathrm{Ea}$ & $4.59 \mathrm{~Eb}$ & $4.32 \mathrm{Ec}$ & $3.58 \mathrm{Ed}$ \\
\hline
\end{tabular}

Means with the same uppercase letters in each column and the same lowercase letters in each line were not significantly different from each other by the Tukey's test at a significance level of 5\%.

At each radiation dose, there were no significant differences in bacterial elimination between samples with 5 and 50 NTU. Besides, at the exposure times of 30, 60, and $90 \mathrm{~s}$, there were no significant differences in bacterial elimination between samples with 200 and 300 NTU. However, above 50 NTU, higher turbidity levels decreased microbial inactivation significantly. Thus, despite applying the same doses, turbidity had a negative effect on UV disinfection, and as dose increases, such differences become greater.

The inactivation of heterotrophic microorganisms using a contact reactor was greater than that obtained by Chhetri et al. (2018), who used similar doses in a reactor without direct contact, indicating that the type of reactor strongly affected disinfection efficiency. Sanctis et al. (2016) found that total coliforms in domestic wastewater decreased by $2.8 \mathrm{logs}$ using a dose of $40 \mathrm{mWs}$ $\mathrm{cm}^{-2}$. In our study, heterotrophic bacteria counts were reduced by $3.0 \operatorname{logs}$ at a dose of $20 \mathrm{mWs}$ $\mathrm{cm}^{-2}$ and by $5 \operatorname{logs}$ at a dose of $28.8 \mathrm{mWs} \mathrm{cm}^{-2}$ in samples with a turbidity of 5 NTU. Nguyen et al. (2019) reported that the total count of E. coli was reduced by 5 logs in domestic wastewater pretreated with a UV dose of $69.4 \mathrm{mWs} \mathrm{cm}^{-2}$ in samples with an initial turbidity of 4 NTU.

Our results were similar to those obtained by Guo et al. (2011), in which counts of E. coli 
and fecal coliforms were reduced by 5 logs, and total counts of $B$. subtilis were reduced by 4 logs using $40 \mathrm{mWs} \mathrm{cm}^{-2}$. However, other studies found that killing efficiency was higher using UV doses lower than $40 \mathrm{mWs} \mathrm{cm}^{-2}$ (Lazarova et al., 1999; Beck et al., 2016; Nyangaresi et al. (2018). Silva et al. (2020) obtained similar results with much lower irradiance intensity using $280 \mathrm{~nm}$ UV-LED $(0.019 \mathrm{~mW} \mathrm{~cm} \mathrm{-} \mathrm{2)} \mathrm{with} \mathrm{a} 4 \log$ reduction of $15 \mathrm{~min}$ E. coli. This wavelength range from 280 to $200 \mathrm{~nm}$, called UVC and used in our experiments, appears to cause more effective and irreversible damage to DNA. Therefore, it is also important to consider this aspect combined with the physicochemical characteristics of the effluent and irradiance intensity.

Previous studies demonstrated that increases in turbidity have a negative effect on UV disinfection effectiveness. Nourmoradi et al. (2012) used a UV reactor like that used in our study and reported that an increase in turbidity from 1 to 5 NTU reduced inactivation effectiveness by $0.2-0.5 \mathrm{log}$. Wu and Doan (2005) also reported a decrease in inactivation efficiency as turbidity increased from 1 to 5 NTU, and Gullian et al. (2012) observed that microbial inactivation decreased as turbidity was raised from 9 to 28 NTU. Likewise, Zhou et al. (2016) reported that increases in turbidity and UV absorbance reduce efficiency of disinfection.

In the above studies, small changes in turbidity had great impacts on disinfection efficiency. However, in ours, only major changes impacted the treatment, even though we expected greater differences after analyzing Figure 3. This discrepancy might have been due to the composition of microalgae used to increase sample turbidity. The phosphate concentration in microalgae is high, and these microorganisms absorb phosphorus from the medium during wastewater treatment (Sajjadi et al., 2018).

Azimi et al. (2014a) reported that floc-forming during biological treatment with polyphosphates would enhance UV-radiation disinfection by acting as photoactive agents and producing oxidative hydroxyl radicals. In addition, effluents with low phosphorus concentrations are more resistant to UV disinfection than effluents with higher phosphorus levels (Azimi et al., 2014b). Thus, the presence of microalgae biomass may have benefited disinfection since, despite the increase in turbidity and reduction in transmittance, its efficiency has not dropped dramatically.

The $\mathrm{k}$ value indicates the sensitivity of microorganisms to UV radiation (Hijnen et al., 2006) and was calculated using Equation 1 (Figure 4). The k values (slopes) varied from 0.1266 to $0.1759 \mathrm{~cm}^{2}(\mathrm{mWs})^{-1}$.

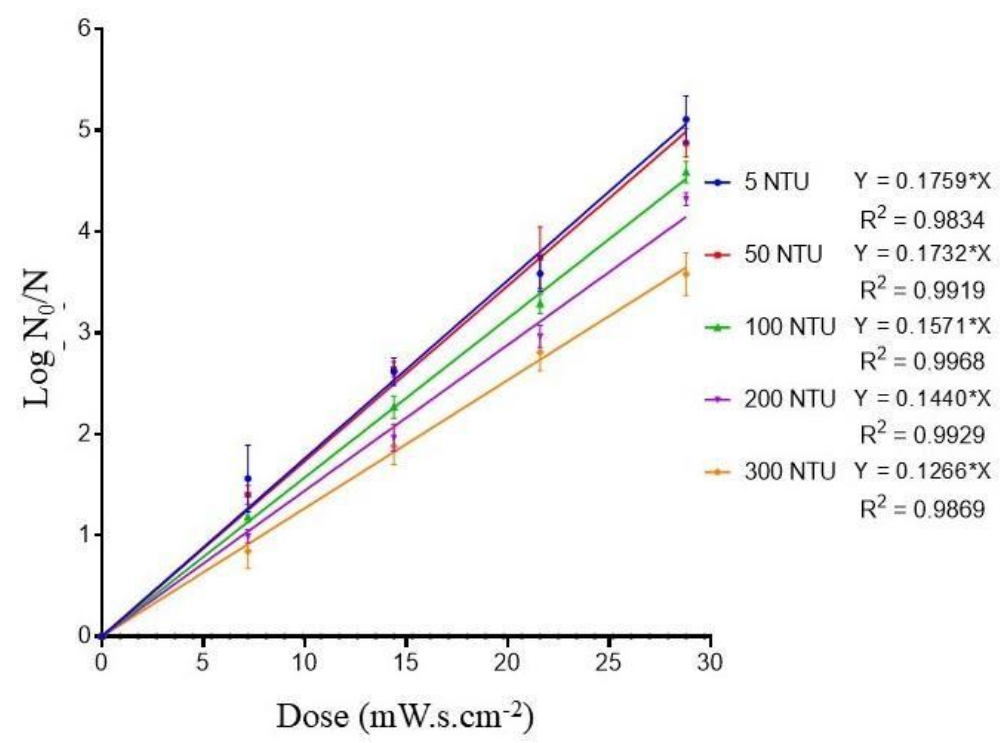

Figure 4. Microbial inactivation profile $\left(\log \mathrm{N}_{0} / \mathrm{N}\right)$ for each turbidity level as a function of UV dose. 
The $\mathrm{k}$ values vary depending on the microorganism, UV radiation system, and the type and physicochemical characteristics of wastewater. The obtained $\mathrm{K}$ values agree with the literature. Zhou et al. (2016) reported that $\mathrm{k}$ values for the UV inactivation of E. coli in municipal wastewater varied between 0.1027 and $0.1887 \mathrm{~cm}^{2} \mathrm{mWs}^{-1}$, and Oguma et al. (2016) found that the $\mathrm{k}$ value for the inactivation of $E$. coli in synthetic media was $0.157 \mathrm{~cm}^{2} \mathrm{~mJ}^{-1}$. In contrast, Beck et al. (2016) reported that the k value for killing E. coli using a low-pressure UV lamp was $0.31 \mathrm{~cm}^{2} \mathrm{mWs}^{-1}$.

Torres-Palma et al. (2017) observed that pretreatment increased the efficiency of UV disinfection, and the $\mathrm{k}$ value for inactivating fecal coliforms in secondary effluents pretreated with hexanol and ultrasound was $0.3 \mathrm{~cm}^{2} \mathrm{mWs}^{-1}$.

The results indicate that the $\mathrm{k}$ values estimated here can be extrapolated to disinfection of effluents at the ETE of CCA/UFSCar, with turbidity values below 300 NTU. This is because thermotolerant coliforms are classified as heterotrophic bacteria.

According to CONAMA Resolution 357/05 (CONAMA, 2005), the maximum concentration of thermotolerant coliforms estimated by the technique of the most probable number (MPN) of CFU per $100 \mathrm{~mL}$ in reuse water should be 100 (Classes 1 and 2) and 2000 (Class 3). The MPN of E. coli in the effluents was $3.53 \times 10^{5}$ (Table 1).

A disinfection efficiency of $99.999 \%$ ( 5 log reduction) would be necessary to obtain a bacterial count of fewer than 2000 coliforms. The time required to achieve this goal can be calculated from the $\mathrm{k}$ value at a given turbidity, with the number of $\log$ cycles required being obtained by the product $\mathrm{k}$ versus dose of UV radiation (D).

\section{CONCLUSION}

Our results indicated that turbidity in wastewater samples influence bacterial inactivation by ultraviolet light. Inactivation coefficients between 0.1266 and $0.1759 \mathrm{~cm}^{2}\left(\mathrm{mWs}^{-1}\right)$ reduce heterotrophic bacteria counts by more than $99.999 \%$, i.e., more than 5 log cycles. This efficiency could be improved by increasing the time of exposure to ultraviolet.

\section{ACKNOWLEDGEMENTS}

The authors are grateful to CAPES, FAPESP - 2013/14893-7 and CNPq.

\section{REFERENCES}

APHA; AWWA; WEF. Standard Methods for the examination of water and wastewater. 22nd ed. Washington, 2012. 1496 p.

ARTICHOWICZ, W.; LUCZKIEWICZ, A.; SAWICKI, J. M. Analysis of the Radiation Dose in UV-Disinfection Flow Reactors. Water, Basel, v. 12, n. 1, p. 231, 2020. https://doi.org/10.3390/w12010231

AZIMI, Y.; ALLEN, D. G.; FARNOOD, R. R. Kinetics of UV inactivation of wastewater bioflocs. Water Research, v. 46, n. 12, p. 3827-3836, 2012. https://doi.org/10.1016/j.watres.2012.04.019

AZIMI, Y.; ALLEN, D. G.; FARNOOD, R. R. Enhancing disinfection by advanced oxidation under UV irradiation in polyphosphate-containing wastewater flocs. Water Research, Amsterdam, v. 54, p. 179-187, 2014a. https://doi.org/10.1016/j.watres.2014.01.011 
AZIMI, Y.; ALLEN, D. G.; SETO, P.; FARNOOD, R. R. Effect of Activated Sludge Retention Time, Operating Temperature, and Influent Phosphorus Deficiency on Floc Physicochemical Characteristics and UV Disinfection. Industrial \& Engineering Chemistry Research, v. 53, v. 31, p. 12485-12493, 2014b. https://doi.org/10.1021/ie5012068

AZIMI, Y.; LIU, Y.; TAN, T. C.; ALLEN, D. C.; FARNOOD, R. R. The tail of two models: Impact of circularity and biomass non-homogeneity on UV disinfection of wastewater flocs. Water Research, Amsterdam, v. 126, p. 70-78, 2017. https://doi.org/10.1016/j.watres.2017.09.011

BECK, S. E.; RODRIGUEZ, R. A.; HAWKINS, M. A.; HARGY, T. M.; LARASON, T. C.; LINDEN, K. G. Comparison of UV-Induced Inactivation and RNA Damage in MS2 Phage across the Germicidal UV Spectrum. Applied and Environmental Microbiology, v. 82, n. 5, p. 1468-1474, 2016. https://doi.org/10.1128/AEM.02773-15

BOLYARD, S. C.; MOTLAGH, A. M.; LOZINSKI, D.; REINHART, D. R. Impact of organic matter from leachate discharge to wastewater treatment plants on effluent quality and UV $\begin{array}{llllll}\text { disinfection. Waste Management, } & \text { v. 88, p. 257-267, }\end{array}$ https://doi.org/10.1016/j.wasman.2019.03.036

BRAHMI, M.; BELHADI, N. H.; HAMDI, H.; HASSEN, A. Modeling of secondary treated wastewater disinfection by UV irradiation: Effects of suspended solids content. Journal of Environmental Sciences, v. 22, p. 1218-1224, 2010. http://dx.doi.org/10.1016/S10010742(09)60241-2

BURCH, J.; THOMAS, K. Water disinfection for developing countries and potential for solar thermal pasteurization. Solar Energy, v. 64, p. 87-97, 1998. http://dx.doi.org/10.1016/S0038-092X(98)00036-X

CARRÉ, E.; PÉROT, J.; JAUZEIN, V.; LOPEZ-FERBER, M. Impact of suspended particles on UV disinfection of activated-sludge effluent with the aim of reclamation. Journal of $\begin{array}{lllllll}\text { Water Process } & \text { Engineering, } & \text { v. } & 22, & \text { p. } & 87-93,\end{array}$ https://doi.org/10.1016/j.jwpe.2018.01.016

CHAI, Q.; HU, A.; QIAN, Y.; AO, X.; LIU, W.; YANG, H.; XIE, Y. F. A comparison of genotoxicity change in reclaimed wastewater from different disinfection processes. $\begin{array}{lllll}\text { Chemosphere, } & \text { v. } & 191, & \text { p. } & 335-341,\end{array}$ https://doi.org/10.1016/j.chemosphere.2017.10.024

CHEVREMONT, A. C.; BOUDENNE, J. L.; COULOMB, B.; FARNET, A. M. Impact of watering with UV-LED-treated wastewater on microbial and physico-chemical parameters of soil. Water Research, v. 47, n. 6, p. 1971-1982, 2013. https://doi.org/10.1016/j.watres.2013.01.006

CHHETRI, R. K.; KLUPSCH, E.; ANDERSEN, H. R.; JENSEN, P. E. Treatment of Arctic wastewater by chemical coagulation, UV and peracetic acid disinfection. Environmental Science and Pollution Research, v. 25, p. 32851-32859, 2018. https://doi.org/10.1007/s11356-017-8585-5

COLliVignARElli, M. C.; ABBÀ, A.; BENIGNA, I.; SORLINI, S.; TORRETTA, V. Overview of the main disinfection processes for wastewater and drinking water treatment plants. Sustainability, v. 10, n. 1, p. 86, 2018. https://doi.org/10.3390/su10010086 
CONAMA (Brasil). Resolução n 357 de 17 de março de 2005. Dispõe sobre a classificação dos corpos de água e diretrizes ambientais para o seu enquadramento, bem como estabelece as condições e padrões de lançamento de efluentes, e dá outras providências. Diário Oficial [da] União: seção 1, Brasília, DF, n. 053, p. 58-63, 18 mar. 2005.

FARRELL, C.; HASSARD, F.; JEFFERSON, B.; LEZIART, T.; NOCKER, A.; JARVIS, P. Turbidity composition and the relationship with microbial attachment and UV inactivation efficacy. Science of the Total Environment, v. 624, p. 638-647, 2018. https://doi.org/10.1016/j.scitotenv.2017.12.173

FAILLY, J. Desinfection des eaux usées par rayonnement ultraviolet. L'eau, l'industrie, les Nuisances, n. 176, p. 58-60, 1994.

GAYAN, E.; MONFORT, S.; ÁLVAREZ, I.; CONDÓN, S. UV-C inactivation of Escherichia coli at different temperatures. Innovative Food Science and Emerging Technologies, Amsterdam, v. 12, n. 4, p. 351-341, 2011. http://dx.doi.org/10.1016/j.ifset.2011.07.008

GIBSON, J.; DRAKE, J.; KARNEY, B. UV Disinfection of wastewater and combined sewer overflows. In: AHMAD, S. (eds.). Ultraviolet Light in Human Health, Diseases and Environment. Advances in Experimental Medicine and Biology. New York: Springer, 2017. https://doi.org/10.1007/978-3-319-56017-5_22

GULLIAN, M.; ESPINOSA-FALLER, F. J.; NÚÑEZ, A.; LÓPEZ-BARAHONA, N. Effect of turbidity on the ultraviolet disinfection performance in recirculating aquaculture systems with low water exchange. Aquaculture Research, v. 43, n. 4, p. 595-606, 2012. https://doi.org/10.1111/j.1365-2109.2011.02866.x

GUO, M.; HU, H.; LIU, W. Preliminary investigation on safety of post-UV disinfection of wastewater: bio-stability in laboratory-scale simulated reuse water pipelines. Desalination, v. 239, p. 22-28, 2009. http://dx.doi.org/10.1016/j.desal.2008.03.003

GUO, M.; HUANG, J.; HU, H.; LIU, W. Growth and repair potential of three species of bacteria in reclaimed wastewater after UV disinfection. Biomedical and Environmental Sciences, v. 24, n. 4, p. 400-407, 2011. https://doi.org/10.3967/0895-3988.2011.04.011

GUO, M.; HUANG, J.; HU, H.; LIU, W.; YANG, J. UV inactivation and characteristics after photoreactivation of Escherichia coli with plasmid: Health safety concern about UV disinfection. Water Research, v. 46, n. 13, p. 4031-4036, 2012. http://dx.doi.org/10.1016/j.watres.2012.05.005

HASSEN, A.; MAHROUK, M.; OUZARI, H.; CHERIF, M.; BOUDABOUS, A.; DAMELINCOURT, J. J. UV disinfection of treated wastewater in a large-scale pilot plant and inactivation of selected bacteria in a laboratory UV device. Bioresource Technology, v. 7, n. 2, p. 141-150, 2000. http://dx.doi.org/10.1016/S0960-8524(99)00179-0

HIJNEN, W. A. M.; BEERENDORK, E. F.; MEDEMA, G. J. Inactivation credit of UV radiation for viruses, bacteria and protozoan (oo)cysts in water: a review. Water Research, v. 40, n. 1, p. 3-22, 2006. https://doi.org/10.1016/j.watres.2005.10.030

LAZAROVA, V.; SAVOYE, P.; JANEX, M. L.; BLATCHLEY, E. R.; POMMEPUY, M. Advanced wastewater disinfection technologies: state of the art and perspectives. Water Science \& Technology, v. 40, n. 4-5, p. 203-213, 1999. https://doi.org/10.1016/S02731223(99)00502-8 
MASSCHELEIN, J.; DEBACKER, S.; CHEBAK, S. Etude sur modèle de la désinfection de l'eau par rayonnements ultraviolets. Reveu des Sciences de l'eau, v. 2, n. 1, p. 29-41, 1989. https://doi.org/10.7202/705022ar

NGUYEN, D. D.; JONES, N. C.; HOFFMANN, S. V.; SPANGET-LARSEN, J. UV synchrotron radiation linear dichroism spectroscopy of the anti-psoriatic drug anthralin. Journal for Physical Chemistry, v. 1, p. e5, 2019. https://doi.org/10.7717/peerjpchem.5

NOURMORADI, H.; NIKAEEN, M.; STENSVOLD, C. R.; MIRHENDI, H. Ultraviolet irradiation: An effective inactivation method of Aspergillus spp. in water for the control of waterborne nosocomial Aspergillosis. Water Research, v. 46, n. 18, p. 5935-5940, 2012. https://doi.org/10.1016/j.watres.2012.08.015

NYANGARESI, P.; QIN, Y.; CHEN, G.; ZHANG, B.; LU, Y.; SHEN, L. Effects of single and combined UV-LEDs on inactivation and subsequent reactivation of $E$. coli in water disinfection. Water Research, v. 147, p. 331-341, 2018. https://doi.org/10.1016/j.watres.2018.10.014

OGUMA, K.; RATTANAKUL, S.; BOLTON, J. R. Application of UV light-emitting diodes to adenovirus in water. Journal of Environmental Engineering, v. 142, n. 3, p. 04015082, 2016. https://doi.org/10.1061/(ASCE)EE.1943-7870.0001061

OLIVEIRA, A. A. S.; BASTOS, R. G.; SOUZA, C. F. Adaptation of domestic effluent for agricultural reuse by biological, physical treatment and disinfection by ultraviolet radiation. Revista Ambiente \& Água, v. 14, n. 2, p. 1-10, 2019. https://doi.org/10.4136/ambi-agua.2292

SAJJADI, B.; CHEN, W. Y.; RAMAN, A. A. A.; IBRAHIM, S. Microalgae lipid and biomass for biofuel production: A comprehensive review on lipid enhancement strategies and their effects on fatty acid composition. Renewable and Sustainable Energy Reviews, v. 97, p. 200-232, 2018. https://doi.org/10.1016/j.rser.2018.07.050

SANCTIS, M.; MORO, G.; LEVANTESI, C.; LUPRANO, M. L.; IACONI, C. Integration of an innovative biological treatment with physical or chemical disinfection for wastewater reuse. Science of the Total Environment, v. 543, p. 206-213, 2016. https://doi.org/10.1016/j.scitotenv.2015.11.006

SILVA, N. B.; LEONEL, L. P.; TONETTI, A. L. UV-LED for safe effluent reuse in agriculture. Water, Air, \& Soil Pollution, v. 231, 343, 2020. https://doi.org/10.1007/s11270-02004742-4

SOUZA, C. F.; BASTOS, R. G.; GOMES, M. P. M.; PULSCHEN, A. A. Efficiency of domestic wastewater treatment plant for agricultural reuse. Revista Ambiente \& Água, v. 10, n. 3, p. 587-597, 2015. https://doi.org/10.4136/ambi-agua.1549

TORRES-PALMA, R.; GIBSON, J.; DROPPO, I.; SETO, P.; FARNOOD, R. Surfactantassisted sono-breakage of wastewater particles for improved UV disinfection. Water, Air, \& Soil Pollution, v. 228, 106, 2017. https://doi.org/10.1007/s11270-017-3283-y

USEPA. Ultraviolet disinfection guidance manual for the final long term 2 enhanced surface water treatment rule, EPA, 815-R-06-007. Washington, 2006. https://nepis.epa.gov/Exe/ZyPURL.cgi?Dockey=600006T3.TXT 
USLU, G.; DEMIRCI, A.; REGAN, J. Efficacy of pulsed UV-Light treatment on wastewater effluent disinfection and suspended solid reduction. Journal Environmental Engineering, v. 141, n. 6, p. 22-28, 2015. http://dx.doi.org/10.1061/(ASCE)EE.19437870.0000912

WU, J.; DOAN, H. Disinfection of recycled red-meat-processing wastewater by ozone. Journal of Chemical Technology and Biotechnology, v. 80, n. 7, p. 828-833, 2005. https://doi.org/10.1002/jctb.1324

ZEWDE, A. A.; ZHANG, L.; LI, Z.; ODEY, E. A. A review of the application of sonophotocatalytic process based on advanced oxidation process for degrading organic dye. Reviews on Environmental Health, v. 34, n. 4, p. 365-375, 2019. https://doi.org/10.1515/reveh-2019-0024

ZHOU, X.; LI, Z.; LAN, J.; YAN, Y.; ZHU, N. Kinetics of inactivation and photoreactivation of Escherichia coli using ultrasound-enhanced UV-C light-emitting diodes disinfection. $\begin{array}{llllll}\text { Ultrasonics Sonochemistry, v. 35, p. 471-477, } 2016 . & \end{array}$ https://doi.org/10.1016/j.ultsonch.2016.10.028 


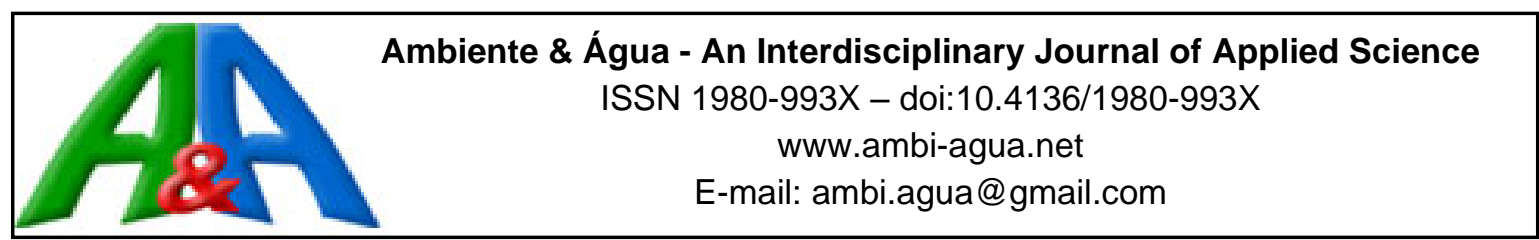

\title{
Filling and validating rainfall data based on statistical techniques and artificial intelligence
}

ARTICLES doi:10.4136/ambi-agua.2767

Received: 05 Jul. 2021; Accepted: 10 Nov. 2021

\section{Camila Bermond Ruezzene ${ }^{1 *}$; Renato Billia de Miranda ${ }^{2}$; Talyson de Melo Bolleli1 ${ }^{1}$; Frederico Fábio Mauad ${ }^{1}$ iD}

\footnotetext{
${ }^{1}$ Escola de Engenharia de São Carlos. Departamento de Hidráulica e Saneamento. Universidade de São Paulo (USP), Avenida Trabalhador são-carlense, n 400, CEP: 13566-590, São Carlos, SP, Brazil. E-mail: bolleli@usp.br, mauadffm@sc.usp.br ${ }^{2}$ Gerência de Cursos e Matrizes. Anhanguera Educacional, Alameda Maria Tereza, n 4266 , CEP: 13278-181, Valinhos, SP, Brazil. E-mail: eng.renato.miranda@gmail.com *Corresponding author. E-mail: camila.ruezzene@gmail.com
}

\begin{abstract}
The study of the hydric regime of rainfall helps in management analysis and decisionmaking in hydrographic basins, but a fundamental condition is the need for continuous time series of data. Therefore, this study compared gap filling methods in precipitation data and validated them using robust statistical techniques. Precipitation data from the municipality of Itirapina, which has four monitoring stations, were used. Four gap filling techniques were used, namely: normal ratio method, inverse distance weighting, multiple regression and artificial neural networks, in the period from 1979 to 1989. For validation and performance evaluation, the coefficient of determination $\left(\mathrm{R}^{2}\right)$, mean absolute error (MAE), mean squared error (RMSE), Nash-Sutcliffe coefficient (Nash), agreement index (D), confidence index were used (C) and through non-parametric techniques with Mann-Witney and Kruskal-Wallis test. Excellent performances of real data were verified in comparison with estimated data, with values above 0.8 of the coefficient of determination $\left(\mathrm{R}^{2}\right)$ and of Nash. Kruskal-Wallis and Mann-Whitney tests were not significant in Stations $\mathrm{C} 1$ and $\mathrm{C} 2$, demonstrating that there is a difference between real and estimated data and between the proposed methods. It was concluded that the multiple regression and neural network methods showed the best performance. From this study, efficient tools were found to fill the gap, thus promoting better management and operation of water resources.
\end{abstract}

Keywords: artificial neural networks, inverse distance weighting, multiple regression, normal ratio method.

\section{Preenchimento e validação em dados de precipitação através de técnicas estatísticas e de inteligência artificial}

\section{RESUMO}

O estudo do regime hídrico das chuvas auxilia nas análises de gestão e em tomadas de decisão nas bacias hidrográficas, mas uma condição fundamental é a necessidade de séries temporais contínuas de dados. Diante disso, o objetivo do presente estudo foi realizar a comparação entre os métodos de preenchimento de falha em dados de precipitação e validá-los 
através de técnicas estatísticas robustas. Foram utilizados dados de precipitação localizados no município de Itirapina que conta com quatro estações de monitoramento. Foi empregado quatro técnicas de preenchimento de falhas, sendo: método razão normal, ponderação distância inversa, regressão múltipla e redes neurais artificiais, no período de 1979 a 1989. Para validação e avaliação do desempenho utilizou-se o coeficiente de determinação $\left(\mathrm{R}^{2}\right)$, erro absoluto médio (MAE), erro quadrático médio (RMSE), coeficiente de Nash-Sutcliffe (Nash), índice de concordância (D), índice de confiança (C) e através de técnicas não paramétricas com teste de Mann-Whitney e Kruskal-Wallis. Foram verificados ótimos desempenhos dos dados reais em comparação aos dados estimados, com valores acima de 0,8 do coeficiente de determinação $\left(\mathrm{R}^{2}\right)$ e de Nash. Para os testes de Kruskal-Wallis e Mann-Whitney não foram significativos nas estações $\mathrm{C} 1$ e $\mathrm{C} 2$, demonstrando que existe diferença entre os dados reais e estimados e entre os métodos propostos. Pôde-se concluir que os métodos de regressão múltipla e redes neurais apresentaram os melhores desempenhos. A partir desse estudo verificou-se ferramentas eficientes para o preenchimento de falha promovendo assim, uma melhor gestão e operação dos recursos hídricos.

Palavras-chave: método razão normal, ponderação distância inversa, redes neurais artificiais, regressão múltipla.

\section{INTRODUCTION}

Rainfall is one of the variables with the greatest influence on society, environment and economy, as it has direct implications for agriculture, climate, hydrology, disaster management, among others. Therefore, evaluating its behavior allows it to assist in the analysis of water availability and decision-making in hydrographic basins. However, for such verifications to be carried out, a fundamental condition is the need for continuous time series of data in order to obtain consistent and reliable results (Correia et al. 2016).

A constant problem in developing countries is the absence of continuous data on meteorological variables and rainfall stations in different regions, which reinforces the importance of making the most of existing data. Since gaps in databases can influence data analysis and inferences, missing data-filling methods, such as multiple regression method (MR), inverse distance weighting (IDW), normal ratio method (NRM), and neural networks (NN), stand out in the scientific environment due to their excellent performance in calculating estimates (Depiné et al., 2014; Wanderley et al., 2014; Khosravi et al., 2015; Correia et al., 2016; Bier and Ferraz, 2017; Coutinho et al. 2018).

Several studies have highlighted the multiple linear regression method as an efficient tool used to fill gaps in time series, such as rainfall, temperature and humidity data, among others. According to Oliveira et al. (2010), multiple linear regression and regional weighting perform better in filling in gaps than regional vector and regional weighting methods based on linear regressions. However, the aforementioned authors have emphasized that these methodologies should not be used without prior regional analysis of their performance.

On the other hand, the inverse distance weighting method is one of the techniques mostly used to estimate missing data in hydrology and geographic sciences, since it presents satisfactory results in filling in gaps about rainfall data (Teegavarapu and Chandramouli, 2005; Shepard, 1968).

Junqueira et al. (2018) have compared different rainfall missing data-filling methodologies and found that methods such as regional weighting, arithmetic mean and regional weighting based on regression have overestimated rainfall rates in the Mortes River Basin (MG), whereas linear regression, multiple regression and inverse distance weighting methods have underestimated them. 
According to Bier and Ferraz (2017), regional weighting was the most suitable method used for missing rainfall data-filling purposes, but it did not significantly stand out in comparison to methods such as multiple linear regression, regional weighting, inverse distance weighting, normal ratio method, United Kingdom traditional method and simple arithmetic mean. Normal ratio method has shown satisfactory results and low mean absolute errors $(18.1 \%)$ in estimates.

The aforementioned authors have also pointed out that these estimates have represented monthly rainfall variations in a reasonable way. They were capable of detecting monthly rainfall peaks between original and estimated series, and it has evidenced the possibility of generating good estimates for monthly and annual rainfall data (Bier and Ferraz, 2017).

Coutinho et al. (2018) used a Multilayer Perceptron-type neural network fault filling tool comparing monthly meteorological variables with Multiple Regression models in four stations in the state of Rio de Janeiro from 2002 to 2014. The neural network model presented a high linear correlation ( $r$ ) with the recorded data of maximum air temperature ( $\mathrm{r}$ from 0.94 to 0.98 ), obtaining a mean percentage error (EMP) between $1.05 \%$ and $2.32 \%$. Regarding the relative air humidity, the $\mathrm{r}$ coefficient remained between 0.77 and 0.94 , and the use of RNA to estimate this variable resulted in an EMP between $1.85 \%$ and $2.41 \%$. They concluded that the neural network method is an effective tool for filling and reliably estimating meteorological variables, as the estimated data were close to the real data.

Given the range of procedures and statistical techniques used to fill in missing data in climate series, it is of paramount importance to select the most appropriate methodology capable of meeting the needs of the study by taking into consideration the climatic and geographical reality the meteorological stations are inserted in, as well as of statistically proving the veracity of estimated data (Fante and Sant'Anna Neto, 2016).

Assessing and validating the performance of hydrological models is a crucial process to justify their continued use, as well as verifying their limitations. In this way, it is necessary to apply statistical criteria to quantify the quality and accuracy of the adjustment, in relation to the measured and estimated data, which enables a comprehensive evaluation of the models, enabling their proper reproduction, the prediction of future behavior and the identification of improvements in modeling.

The most commonly used criteria for evaluating models are commonly divided between performance indices, which include: coefficient of determination $\left(\mathrm{R}^{2}\right)$, agreement (d) and confidence (c) index, and Nash-Sutcliffe efficiency (Nash) and error checking measures such as mean absolute error (MAE) and mean squared error (RMSE). There are no standard procedures in the literature to assess the performance of models, but it is preferable that different statistical techniques are applied, as different metrics quantify various aspects of model fit and accuracy, providing a quantitative and objective assessment of the agreement between simulated and estimated data (Jackson, 2019).

Thus, the present study compared gap filling methods in precipitation data and validated them using robust statistical techniques.

\section{MATERIALS AND METHODS}

\subsection{Study site featuring}

The study site is located in Itirapina County-SP (Figure 1), approximately $218 \mathrm{~km}$ away from the capital; its population is estimated as 18,157 inhabitants and its territorial area covers $564.60 \mathrm{~km}^{2}$ comprising Cerrado and Atlantic Forest biomes (IBGE, 2019).

The county has two important conservation units, namely: Experimental Station and Ecological Station. They are managed by the Forestry Institute, which manages an area of 5,512 hectares and aims at environmental preservation, research and education. The water network in these units, together with the other water bodies, are of paramount importance because they 
play a key role in the overall balance of the region (Silva et al., 2006).

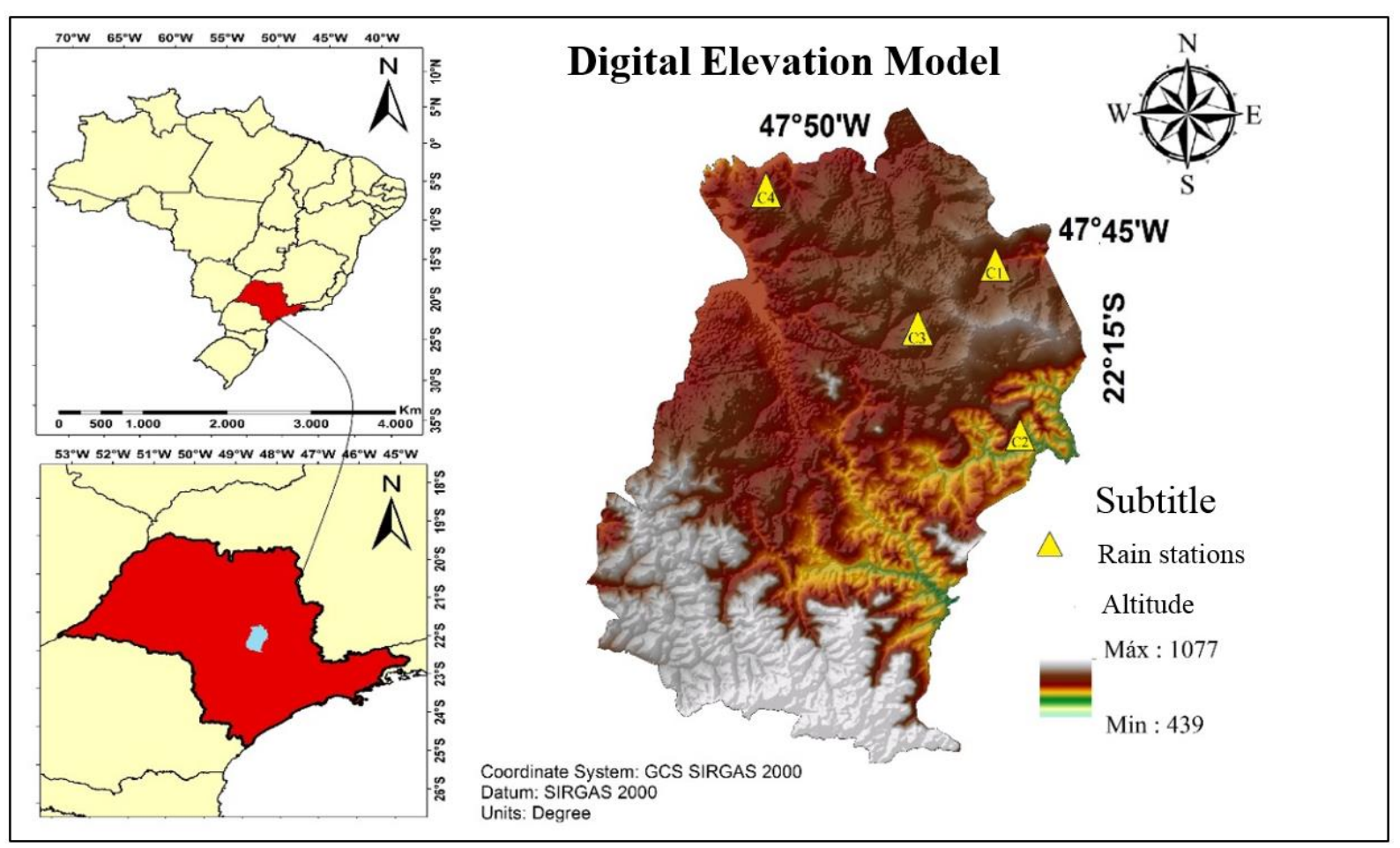

Figure 1. Location of the study area.

Itirapina County is located in the Cuestas Basálticas region, on São Carlos Plateau. The climate in the region is classified as Cwa, based on Köppen's classification. Summer is hot and rainy, whereas winter is dry. Seasonality observed in the region comprises dry semester from April to September, as well as rainy semester from October to March. Mean annual rainfall reaches $1,450 \mathrm{~mm}$ per year and mean annual temperature is approximately $20.8^{\circ} \mathrm{C}$ (CEPAGRI, 2009; Santos et al., 2018b).

According to Santos et al. (2018a), land use and cover classification in Itirapina County corresponds to native vegetation (30.68\%), agricultural crops such as sugarcane $(19.93 \%)$, forestry $(18.37 \%)$, citrus culture $(1.55 \%)$, exposed soil $(11.97 \%)$ and pasture $(14.55 \%)$. The aforementioned authors have emphasized that the region presents low environmental vulnerability level due to its flat terrain and to the incidence of Oxisol in the county.

\subsection{Rainfall data}

Monthly historical data about rainfall recorded in Itirapina County (SP) from 1979 to 1989 were selected from stations available at the HIDROWEB portal, on the National Water Agency (ANA, 2020) platform. Table 1 shows the stations and their respective codes, altitude, geographic coordinates, as well as the time (in years) of each analyzed series - these data were consolidated before they were made available.

Table 1. Rain stations located in Itirapina County.

\begin{tabular}{ccccc}
\hline Adopted nomenclature & Code & Altitude & Latitude & Longitude \\
\hline C1 & 2247180 & 760 & $22^{\circ} 08^{\prime} 54^{\prime \prime}$ & $47^{\circ} 47^{\prime} 42^{\prime \prime}$ \\
C2 & 2247184 & 610 & $22^{\circ} 18^{\prime} 01^{\prime \prime}$ & $47^{\circ} 44^{\prime} 38^{\prime \prime}$ \\
C3 & 2247196 & 732 & $22^{\circ} 10^{\prime} 12^{\prime \prime}$ & $47^{\circ} 53^{\prime} 56.04^{\prime \prime}$ \\
C4 & 2247198 & 690 & $22^{\circ} 10^{\prime} 00^{\prime \prime}$ & $47^{\circ} 54^{\prime} 00^{\prime \prime}$ \\
\hline
\end{tabular}

Source: Adapted from ANA (2020). 
The period from 1979 to 1989 was adopted due to the need to work with a continuous series of data, allowing better representation of the characteristics present in each station and the comparison of real and estimated data for each proposed method, using all stations available for that municipality. The climatological station (C4) located at the Center for Water Resources and Environmental Studies (CRHEA/USP) was included in the group of meteorological stations because it makes it possible to work with primary data. Considering all available data from this period of study, $11.37 \%$ of the data were removed and thus obtained in a homogeneous series and with the same number of data for all stations according to the methodology of Coutinho et al. (2018).

\subsection{Missing data-filling}

Criteria adopted to select the tested methods took into consideration methodologies already consolidated in the field. Thus, rather than being not limited to a single methodology, the current study used several of them in order to compare and validate them, based on different statistical techniques that will be addressed throughout the methodology and results. The following techniques stood out among the main missing data-filling methods and they were used in the current study: multiple regression (MR); inverse distance weighting (IDW), normal ratio method (NRM) and artificial neural networks (ANNs).

\subsubsection{Multiple regression (MR)}

Rainfall information about the behavior of a dependent variable $Y$ in multiple regression depends on two, or more, independent variables $X j, j=1, \ldots, p$ (Naghettini and Pinto, 2007). Therefore, a model likely to evaluate this association is enabled by Equation 1.

$Y i=\beta 0+\beta 1 X i 1+\beta 2 X i 2+\ldots+\beta p X i p+e i, i=1, \ldots, n$

Where in: $n$ is the number of observations, $Y_{i}$ is the observation of the dependent variable for the $i$-th individual, $X_{i}=\left(X_{i 1}, X_{i 2}, \ldots, X_{i p}\right)$ is a vector of observations of independent variables for the $i$-th individual, $\beta=\left(\beta_{0}, \beta_{1}, \beta_{2}, \ldots, \beta_{p}\right)$ is a vector of regression coefficients (parameters) and $e_{i}$ is a random error component.It is presumed that these errors are independent and follow normal distribution with mean equal to zero and unknown variance $\sigma^{2}$.

\subsubsection{Inverse Distance Weighting (IDW)}

The inverse distance weighting method is applied through the linear combination of observations within a given research radius, whose influence decreases as distance increases. According to Hubbard (1994), the IDW method for missing data-filling is calculated based on Equation 2.

$D_{x}=\frac{\sum_{i=1}^{n}\left(D_{i} / d_{i}\right)}{\sum_{i=1}^{n}\left(1 / d_{i}\right)}$

Where in: $D x$ is the missing monthly data to be filled in the test station, $D_{i}$ corresponds to data deriving from the neighboring station of order " $i$ " in the month when the failure in the test station takes place, and $d_{i}$ is the distance between the test station and the neighboring station of order "i".

\subsubsection{Normal Ratio Method (NRM)}

According to Young (1992), the normal ratio method lies on weighting data based on records performed at neighboring stations; such a ratio can be calculated through Equation 3.

$$
D_{x}=\frac{\sum_{i=1}^{n} D_{i} w_{i}}{\sum_{i=1}^{n} w_{i}}
$$


Where in: $D x$ is the monthly data that needs to be filled in the test station, $D i$ corresponds to data deriving from the neighboring station of order " $i$ " in the month when the failure in the test station takes place, and wi is the weight assigned to each neighboring station of order "i", as described in Equation 4.

$$
w_{i}=r_{i}^{2}\left(\frac{n_{i}-2}{1-r^{2}}\right)
$$

Where in: $r_{i}$ is the correlation between the test station and the neighboring station of order " $i$ ", and $n_{i}$ is the number of months when data overlapped between the test station and the neighboring station of order " $i$ ". In other words, it is the size of the data series used to calculate the correlation coefficient.

\subsubsection{Artificial Neural Networks (ANN)}

Neural networks are calculated through mathematical functions; they are naturally prone to store knowledge and make it useful, like the process carried out by the human brain. Nonlinear functions are calculated, which can be appropriate for complex analyses, such as estimating rainfall data (Di Piazza et al., 2011; Depiné et al., 2014; Wanderley et al., 2014; Correia et al., 2016; Coutinho et al., 2018).

The current study has used Multilayer Perceptron (MLP) neural networks due to their greater versatility and applicability in this field. This network type can be used to estimate information and new desired conditions, as well as to find accurate answers to the analyses in question (Wanderley et al., 2014).

Figure 2 shows an example of the neural network architecture corresponding to a station. Networks were trained in the MATLAB software, Version R2015a (https://www.mathworks.com/products/matlab.html) developed by the MathWorks company. It was done by using the Feed-forward backpropagation network type and mean square error as a performance function. The current research has defined that the network architecture should have 3 inputs (corresponding to the stations located in the county), 2 layers, 10 neurons, 1 output and a tan-sigmoid activation function. With respect to network training and validation, $70 \%$ of data were used for training; $15 \%$, for testing; and 15\%, for validation purposes, as established by the software itself.

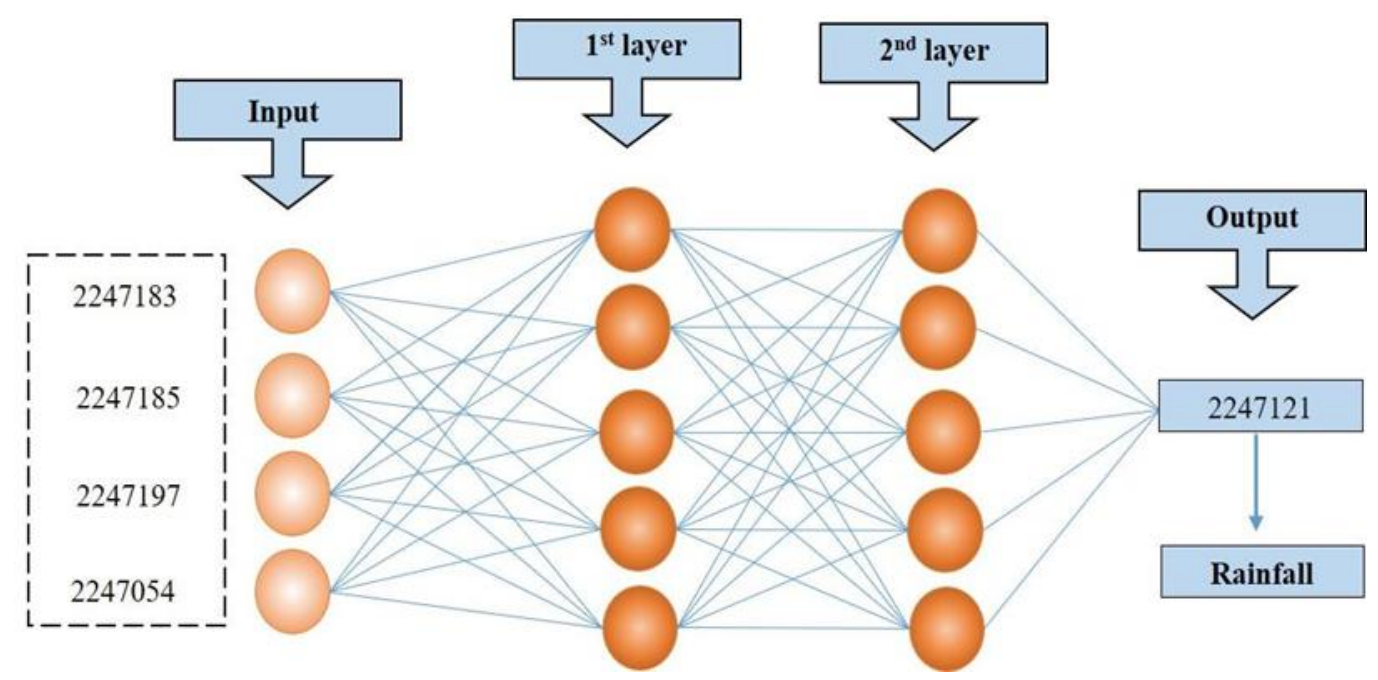

Figure 2. Neural network configuration for Itirapina County, from 1979 to 1989.

As in the example in Figure 2, to fill in the precipitation data for Station 2247180, all available data for that station was removed and three stations were used as input data and one 
for output, obtaining a total of four networks for this municipality carrying out this entire process for the four seasons. Each trained neural network recognizes and adapts to the characteristic patterns of each station's rainfall data, providing gap-filling results.

\subsection{Method-performance validation and evaluation}

The coefficient of determination $\left(\mathrm{R}^{2}\right)$ was calculated to verify the relationship between estimated and measured data. To assess the performance and errors of the failure filling methods, parameters such as mean absolute error (MAE), mean square error (RMSE), index of agreement (D), Pearson's correlation coefficient (r), confidence index (C) and Nash-Sutcliffe efficiency coefficient (Nash), which are applied in several hydrological studies (Goyal, 2014; Pereira et al., 2014; Wanderley et al., 2014; Bier and Ferraz, 2017; Coutinho et al., 2018; Junqueira et al., 2018).

\subsubsection{Coefficient of determination $\left(R^{2}\right)$}

The coefficient of determination $\left(\mathrm{R}^{2}\right)$ (Equation 5) assesses the quality of model fit and indicates the extent to which it was capable of explaining the reference data - the higher the recorded value, the better it fits the model.

$$
R^{2}=\frac{\sum_{i-1}^{n}\left(\hat{Y}_{i}-\bar{Y}\right)^{2}}{\sum_{i-1}^{n}\left(Y_{i}-\bar{Y}\right)^{2}}=1-\frac{\sum_{i-1}^{n} e_{i}^{2} /(n-1)}{\sum_{i-1}^{n}\left(Y_{i}-\bar{Y}\right)^{2} /(n-1)}
$$

Where in: $\mathrm{R}^{2}$ is the coefficient of determination measured in (\%), $Y_{i}$ is the observed value of the dependent variable, $\hat{Y}_{i}$ is the estimated value of the dependent variable, and $Y$ is the mean recorded for the dependent variable.

\subsubsection{Mean absolute error (MAE)}

According to Alves et al. (2012), MAE refers to the mean absolute deviation of interpolated values in comparison to the observed ones. It is considered an accurate and robust measure to check numerical models; ideally, its values should be as close or equal to zero as possible (Equation 6).

$$
M A E=\frac{\sum_{j=1}^{n}\left|o_{j}-x_{j}\right|}{n}
$$

Where in: MAE is the mean absolute error $(\mathrm{mm}), O_{j}$ concerns values observed in the measurement stations, $x_{j}$ corresponds to values estimated through the missing data-filling method, and " $n$ " is the number of observations.

\subsubsection{Root mean square error $(R M S E)$}

RMSE enables checking the mean magnitude of estimated errors. The obtained value is always positive; the closer to zero, the better the estimated values. This parameter can be calculated through Equation 7.

$$
R M S E=\sqrt{\frac{\sum_{j=1}^{n}\left(o_{j}-x_{j}\right)^{2}}{n}}
$$

Where in: RMSE is the mean square error $(\mathrm{mm}), O_{j}$ concerns values observed in the measurement stations, $x_{j}$ corresponds to values estimated by the missing data-filling method, and " $n$ " is the number of observations.

\subsubsection{Confidence (c) and agreement (d) indices}

The confidence index enables checking the precision and accuracy of results. The index of 
agreement is used in different simulations of a single phenomenon. Values recorded for this index range from 0 (lack of agreement) to 1 (excellent agreement). Table 2 shows the criteria used to assess performance. These parameters can be calculated through Equations 8, 9 and 10.

$$
\begin{aligned}
& D=1-\frac{\sum_{j=1}^{n}\left(o_{j}-x_{j}\right)^{2}}{\sum_{j=1}^{n}\left(\left|x_{j}-\bar{O}\right|+\left|o_{j}-\bar{O}\right|\right)^{2}} \\
& r=\frac{\frac{\sum_{j=I}^{N}\left(x_{j}-\bar{x}\right) \times\left(o_{j}-\bar{O}\right)}{N}}{\frac{\sqrt{\sum_{j=1}^{N}\left(x_{j}-\bar{x}\right)^{2}}}{N} \times \frac{\sqrt{\sum_{j=1}^{N}\left(O_{j}-\bar{O}\right)^{2}}}{N}} \\
& C=(r \times D)
\end{aligned}
$$

Where in: D refers to the agreement index (dimensionless), $r$ Pearson's correlation coefficient (dimensionless), $\mathrm{C}$ confidence index (dimensionless); $O_{j}$ are the values observed at

\begin{tabular}{|c|c|}
\hline C value & Performance \\
\hline$>0.85$ & Excellent \\
\hline 0.76 a 0.85 & Very good \\
\hline 0.66 a 0.75 & Good \\
\hline 0.61 a 0.65 & Intermediate \\
\hline 0.51 a 0.60 & Tolerable \\
\hline 0.41 a 0.50 & Poor \\
\hline$\leq 0.40$ & Terrible \\
\hline
\end{tabular}
the measurement stations, $\underline{O}$ mean of observed values, $\underline{x}$ mean estimated values, $x_{j}$ correspond to values estimated by the filling method and $n$ to the number of observations.

Source: Coutinho et al. (2018).

\subsubsection{Nash-Sutcliffe efficiency coefficient (Nash)}

The Nash-Sutcliffe efficiency coefficient (Equation 11) is one of the most important and usual statistical methods applied in hydrology to assess the performance of hydrological models, as described by Pereira et al. (2014). This coefficient can range from - $\infty$ to 1 ; the value corresponding to 1 represents the ideal adjustment of estimated data.

$$
\text { Nash }=1-\frac{\sum_{\mathrm{i}=1}^{\mathrm{n}}\left(\mathrm{X}_{\mathrm{obs}, \mathrm{i}}-\mathrm{X}_{\text {sim }}\right)^{2}}{\sum_{\mathrm{i}=1}^{\mathrm{n}}\left(\mathrm{X}_{\mathrm{obs}, \mathrm{i}}-\overline{\mathrm{X}}_{\mathrm{obs}}\right)^{2}}
$$

Where in: Nash is the Nash-Sutcliffe efficiency coefficient (dimensionless), $X_{o b s}$ are the observed rainfall data, $X_{\text {sim }}$ are the rainfall data simulated by the model, $\underline{X}_{o b s}$ is the mean recorded for data observed during the simulation period, and $\mathrm{n}$ is the number of events.

Model classification was herein adopted based on Silva et al. (2006): models presenting coefficient value higher than 0.75 were classified as adequate and good, those whose coefficient value ranged from 0.36 to 0.75 were classified as acceptable, whereas the ones presenting coefficient value lower than 0.36 were considered unacceptable.

\subsubsection{Descriptive and inferential analysis and data normality tests}

The assumption of normality was checked through the Anderson Darling test, due to its 
sensitivity in giving more weight to distribution tail points (Espinosa et al., 2004). ShapiroWilk test was also applied, since it is one of the most efficient tests used to identify non-normal data (Shapiro and Wilk, 1965).

Both normality tests adopted a significance level of $0.05 . \mathrm{H}_{0}-$ which corresponds to data presenting normal distribution - was rejected whenever p-values were lower than 0.05 . Thus, whenever such data did not show normality, they were subjected to non-parametric analysis techniques, as well as to data median analysis.

The following hypotheses were used in the Anderson Darling and Shapiro-Wilk tests:

$\mathrm{H}_{0:}$ data follow normal distribution.

$\mathrm{H}_{1:}$ data do not follow normal distribution.

\subsubsection{Mann-Whitney (MW) and Kruskal-Wallis (KW) non-parametric tests}

Mann-Whitney non-parametric test was carried out at a significance level of 0.05 in order to test whether there were significant differences between the value estimated through the methods and the real rainfall reference data. $\mathrm{H}_{0}$ was accepted and $\mathrm{H}_{1}$ was rejected whenever the p-value was higher than the significance level - the two samples presented the same distribution (Triola, 2008).

\section{Hypothesis testing:}

$\mathrm{H}_{0}$ : data derived from equal samples.

$\mathrm{H}_{1}$ : data derived from different samples.

Non-parametric KW test initially suggested by Kruskal and Wallis (1952) was also applied at significance level of 0.05 in order to determine whether the medians among all four (4) missing data-filling methods used in the current study have significantly differed from each other. Thus, the null hypothesis was rejected whenever p-value was lower than, or equal to, the significance level, and it led to the conclusion that not all medians were equal to each other.

\section{RESULTS AND DISCUSSION}

Figure 3 shows the time-based rainfall variability among all four stations located in Itirapina County. They followed similar behavior, i.e., they recorded the highest rainfall values in January 1983 and 1981 (554 mm and $441.2 \mathrm{~mm}$, respectively), which corresponded to the C4 station of CRHEA-USP.

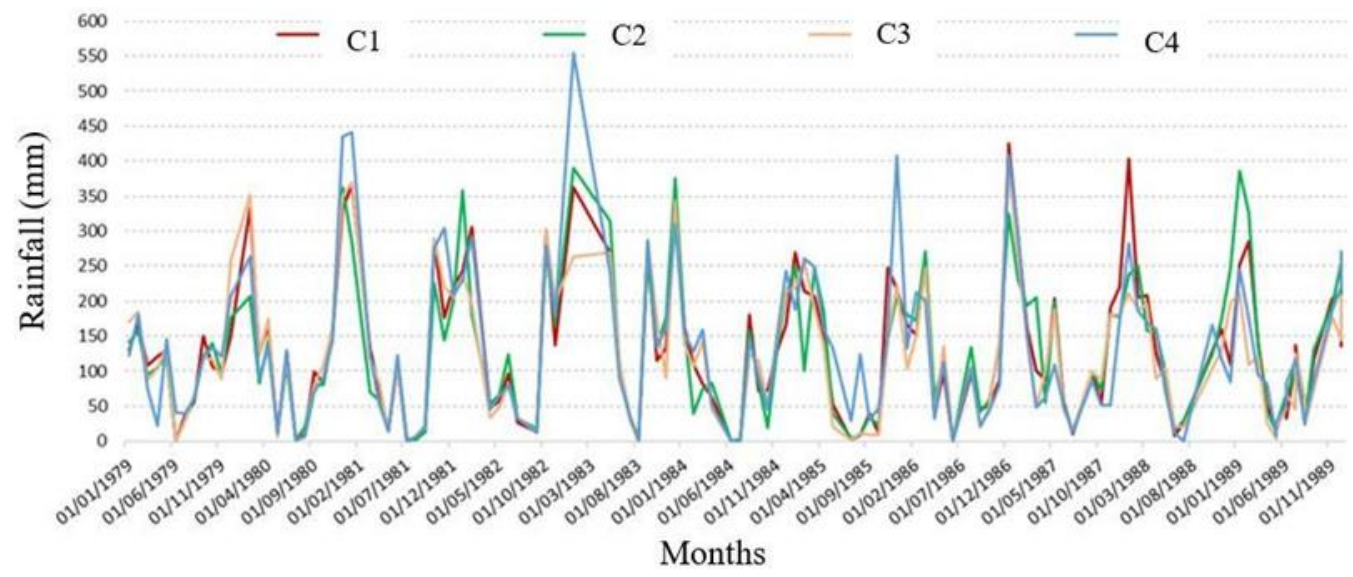

Figure 3. Time-based rainfall variation in all four investigated stations, from 1979 to 1989. 
Souza and Galvani (2017) have analyzed rainfall events recorded by 16 stations located in the Jacaré Guaçu River Basin, Itirapina County, from 1968 to 1998. Results have shown that this region presents great spatial and temporal variability in rainfall events, as seen in tropical areas. The annual rainfall amplitude among the analyzed stations reached $366.6 \mathrm{~mm}$, whereas the seasonal amplitude reached $70.8 \mathrm{~mm}$ in the lesser rainy period and $291.4 \mathrm{~mm}$ in the rainy period.

The full analysis of all series played a key role in helping to find likely explanations for temporal-spatial rainfall dynamics and for its main factors acting in the investigated river basin. Such representative features of each station have directly influenced results recorded for each method.

After the preliminary analysis was over, Anderson Darling and Shapiro-Wilk normality tests were applied to all real and estimated data; results of both tests have shown p-value lower than the significance level of 0.05 , and it enabled concluding that the analyzed data did not follow normal distribution. Lima et al. (2008) have found similar results and indicated that high monthly rainfall variability is a decisive factor for such a behavior. Thus, non-parametric statistics should be used for other analyses.

\subsection{Evaluating the performance of the missing data-filling method applied in Itirapina County}

Tables 3, 4, 5 and 6 show the performance analysis applied to the normal ratio method, inverse distance weighting, multiple regression and neural networks, respectively, based on coefficient of determination $\left(\mathrm{R}^{2}\right)$, mean absolute error (MAE), root mean square error (RMSE), Nash-Sutcliffe efficiency coefficient (Nash), index of agreement (D), confidence index (C) and performance.

Table 3. Performance of the normal ratio method based on $\mathrm{R}^{2}$, MAE, RMSE, Nash, D, $\mathrm{C}$ and performance generated for all stations, from 1979 to 1989.

\begin{tabular}{cccccccc}
\hline Station & $\mathrm{R}^{2}(\%)$ & MAE $(\mathrm{mm})$ & RMSE $(\mathrm{mm})$ & Nash & $\mathrm{D}$ & $\mathrm{C}$ & Performance \\
\hline C1 & 0.899 & 21.030 & 32.090 & 0.898 & 0.972 & 0.922 & Excellent \\
C2 & 0.820 & 27.242 & 42.955 & 0.807 & 1.000 & 0.903 & Excellent \\
C3 & 0.844 & 25.939 & 39.426 & 0.824 & 1.000 & 0.919 & Excellent \\
C4 & 0.815 & 28.714 & 46.123 & 0.814 & 1.000 & 0.903 & Excellent \\
\hline
\end{tabular}

Table 4. Performance of the inverse distance weighting method based on $\mathrm{R}^{2}$, MAE, RMSE, Nash, D, C and performance generated for all stations, from 1979 to 1989.

\begin{tabular}{cccccccc}
\hline Station & $\mathrm{R}^{2}(\%)$ & MAE $(\mathrm{mm})$ & RMSE $(\mathrm{mm})$ & Nash & $\mathrm{D}$ & $\mathrm{C}$ & Performance \\
\hline $\mathrm{C} 1$ & 0.895 & 36.253 & 53.353 & 0.721 & 0.906 & 0.857 & Excellent \\
$\mathrm{C} 2$ & 0.810 & 51.676 & 71.211 & 0.470 & 0.816 & 0.735 & Good \\
$\mathrm{C} 1$ & 0.829 & 28.504 & 41.144 & 0.810 & 0.944 & 0.859 & Excellent \\
$\mathrm{C} 4$ & 0.844 & 36.860 & 59.860 & 0.690 & 0.934 & 0.858 & Excellent \\
\hline
\end{tabular}

Table 5. Performance of the multiple regression method based on $\mathrm{R}^{2}$, MAE, RMSE, Nash, D, C and performance generated for all stations, from 1979 to 1989.

\begin{tabular}{cccccccc}
\hline Station & $\mathrm{R}^{2}(\%)$ & MAE $(\mathrm{mm})$ & RMSE $(\mathrm{mm})$ & Nash & $\mathrm{D}$ & $\mathrm{C}$ & Performance \\
\hline $\mathrm{C} 1$ & 0.906 & 20.271 & 30.987 & 0.896 & 0.975 & 0.928 & Excellent \\
$\mathrm{C} 2$ & 0.843 & 25.296 & 38.768 & 0.813 & 0.956 & 0.878 & Excellent \\
$\mathrm{C} 1$ & 0.869 & 24.390 & 34.169 & 0.849 & 0.964 & 0.899 & Excellent \\
$\mathrm{C} 4$ & 0.931 & 29.558 & 44.369 & 0.795 & 0.946 & 0.913 & Excellent \\
\hline
\end{tabular}


Table 6. Performance of the neural network method based on $\mathrm{R}^{2}$, MAE, RMSE, Nash, D, C and performance generated for all stations, from 1979 to 1989.

\begin{tabular}{cccccccc}
\hline Station & $\mathrm{R}^{2}(\%)$ & MAE $(\mathrm{mm})$ & $\mathrm{RMSE}(\mathrm{mm})$ & Nash & $\mathrm{D}$ & $\mathrm{C}$ & Performance \\
\hline $\mathrm{C} 1$ & 0.903 & 17.486 & 26.784 & 0.931 & 0.982 & 0.933 & Excellent \\
$\mathrm{C} 2$ & 0.884 & 23.151 & 33.197 & 0.867 & 0.968 & 0.910 & Excellent \\
$\mathrm{C} 1$ & 0.884 & 21.605 & 32.985 & 0.872 & 0.968 & 0.910 & Excellent \\
$\mathrm{C} 4$ & 0.828 & 25.676 & 44.828 & 0.831 & 0.956 & 0.870 & Excellent \\
\hline
\end{tabular}

All four methods used in the current research - namely: NRM, IDW, MR and NN presented excellent performances in all stations in Itirapina County. Values recorded for coefficient of determination $\left(\mathrm{R}^{2}\right)$ and Nash coefficient were higher than 0.8 ; except for station $\mathrm{C} 4$, which recorded Nash coefficient value of 0.795 . The other parameters presented low error values. Based on the MR method, stations $\mathrm{C} 1$ and $\mathrm{C} 4$ have shown the best performances in $\mathrm{R}^{2}$ ( 0.906 and 0.931 , respectively). Based on $\mathrm{NN}$, station $\mathrm{C} 1$ presented the best performance in $\mathrm{R}^{2}$ and Nash coefficient, as well as the lowest error values in comparison to other methods.

Similar results were reported by Coutinho et al. (2018), who analyzed multiple linear regression and neural network models. According to them, linear regression methods have shown satisfactory results, high correlation indices and low mean errors in comparison to real data.

Depiné et al. (2014) Correia et al. (2016) and Wanderley et al. (2014) have also concluded that the neural network method has efficiently reproduced the missing rainfall data-filling process and made it possible to compare the complex inputs and outputs of simulations. However, the aforementioned authors have pointed out that there may be variations in the results due to the procedure adopted for network testing, training and validation processes. They also highlighted that estimated data are more accurate when there is lower spatial variability in rainfall events.

Table 7 shows the p-values of the Mann-Whitney test corresponding to each method and station. It was done to investigate whether there was significant difference between real and estimated data. The p-values of Kruskal-Wallis test are also shown to help identify whether there was significant difference among the proposed methods.

Table 7. p-values of Mann-Whitney (MW) and KruskalWallis (KW) tests.

\begin{tabular}{cccccc}
\hline Station & MW-NRM & MW-IDW & MW-MR & MW-NN & KW \\
\hline C1 & 0.024 & 0.024 & 0.788 & 0.633 & 0.018 \\
C2 & 0.868 & 0 & 0.860 & 0.934 & 0.001 \\
C3 & 0.569 & 0.459 & 0.864 & 0.980 & 0.380 \\
C4 & 0.847 & 0.125 & 0.776 & 0.873 & 0.176 \\
\hline
\end{tabular}

Thus, NRM was not significant for Station C1 since the p-value was lower than 0.05. With respect to the IDW method, two of the four stations did not show significant values, namely: Stations C1 (p-value 0.024) and C2 (p-value 0). The other two stations have reached p-values of 0.459 and 0.125 for Stations C1 and C3, respectively. The MR and NN methods, on the other hand, recorded p-values higher than the significance level, indicating lack of difference between real and estimated data. Based on the NN method, all stations recorded a p-value higher than 0.7, except for Station C1. Thus, it is worth emphasizing the importance of adopting in-depth non-parametric statistical methods to perform this analysis type, since the exclusive use of Nash and determination coefficients may not help in identifying such issues.

The Krukal-Wallis test has evidenced significant differences among the four methods applied to Stations C1 and C2, which recorded p-values of 0.018 and 0.001 , respectively. Significant p-values were observed for the other stations, although there was no difference 
among the four analyzed methods. It is worth emphasizing that the neural networks subjected to KW test recorded the best performance for Station C1, whereas MR, NRM and IDW presented inferior performances; however, any of the investigated methods can be used for missing data-filling purposes.

Non-parametric analyses applied to the two stations (C1 and $\mathrm{C} 2)$ that did not record significant p-values have indicated significant differences between actual and estimated data. This outcome can be explained by the orographic effect associated with that region, as well as by episodes of rainfall rate fluctuations that were not identified by the NRM and IDW methods, a fact that hindered the estimates.

\section{FINAL CONSIDERATIONS}

The missing data-filling methods used and validated through the herein-adopted statistical techniques presented excellent performances. Based on analyses applied to all four methods, neural networks and multiple regression were the ones presenting the best results; thus, they are the most suitable methods to be used for missing rainfall data-filling purposes.

Thus, based on the use of efficient missing data-filling tools, it is possible to minimize the social, environmental and economic consequences by promoting better water-resource management and operation by public and private agents, as well as by society as a whole. In addition, these tools can help mitigate issues such as flooding, drought, water supply, electric power generation, among others, enabling the use of continuous data series for these studies.

\section{ACKNOWLEDGMENTS}

The authors would like to thank the National Council for Scientific and Technological Development (CNPq) to the first and third author.

\section{REFERENCES}

AGÊNCIA NACIONAL DE ÁGUAS (Brasil). Website. Available at: http://www3.ana.gov.br/portal/ANA/panorama-das-aguas/quantidade-da-agua. Access: February $15^{\text {th }}, 2020$.

ALVES, E. D. L.; BIUDES, M. S.; VECCHIA, F. A. Z. Interpolação espacial na climatologia: análise dos critérios que precedem sua aplicação. Geonorte, v. 3, n. 8, p. 606-618, 2012.

BIER, A. A.; FERRAZ, S. E. T. Comparação de metodologias de preenchimento de falhas em dados meteorológicos para estações no sul do Brasil. Revista Brasileira de Meteorologia, v. 32, n. 2, p. 215-226, 2017. https://doi.org/10.1590/0102-77863220008

CEPAGRI. Clima dos Municípios Paulistas. Available at: http://www.cpa.unicamp.br/outrasinformacoes/clima_muni_272.html. Access: October $20^{\text {th }}, 2020$.

CORREIA, T. P. et al. Aplicação de redes neurais artificiais no preenchimento de falhas de precipitação mensal na região serrana do Espírito Santo. Geociências, v. 35, n. 4, p. 560567, 2016.

COUTINHO, E. R. et al. Application of artificial neural networks (ANNs) in the gap filling of meteorological time series. Revista Brasileira de Meteorologia, v. 33, n. 2, p. 317-328, 2018. https://doi.org/10.1590/0102-7786332013 
DEPINÉ, H. et al. Preenchimento de falhas de dados horários de precipitação utilizando redes neurais artificiais. Revista Brasileira de Recursos Hídricos, v. 19, n. 1, p. 51-63, 2014.

DI PIAZZA, A. et al. Comparative analysis of different techniques for spatial interpolation of rainfall data to create a serially complete monthly time series of precipitation for Sicily, Italy. International Journal of Applied Earth Observation and Geoinformation, v. 13, n. 3, p. 396-408, 2011. https://doi.org/10.1016/j.jag.2011.01.005

ESPINOSA, M. M.; CALIL JÚNIOR, C.; LAHR, F. A. R. Métodos paramétricos e não paramétricos para determinar o valor característico em resultados de ensaio de madeira. Scientia Forestalis, n. 66, p. 76-83, 2004.

FANTE, K. P.; SANT'ANNA NETO, J. L. Técnicas estatísticas para a homogeneização de dados de temperatura em séries temporais climatológicas. Revista Brasileira de Climatologia, v. 18, p. 143-156, 2016. http://dx.doi.org/10.5380/abclima.v18i0.43202

GOYAL, M. K. Monthly rainfall prediction using wavelet regression and neural network: an analysis of 1901-2002 data, Assam, India. Theoretical and Applied Climatology, v. 118, n. 1-2, p. 25-34, 2014. https://dx.doi.org/10.1007/s00704-013-1029-3

HUBBARD, K. G. Spatial variability of daily weather variables in the high plains of the USA. Agricultural and Forest Meteorology, v. 68, n. 1, p. 29-41, 1994. https://doi.org/10.1016/0168-1923(94)90067-1

IBGE. Censo 2010. Available at: https://cidades.ibge.gov.br. Access: September $10^{\text {th }}, 2019$.

JACKSON, E. K. Introductory overview: Error metrics for hydrologic modelling - A review of common practices and an open source library to facilitate use and adoption. Environmental Modelling \& Software, v. 119, p. 32-48, 2019.

JUNQUEIRA, R.; AMORIM, J. S.; OLIVEIRA, A. S. Comparação entre diferentes metodologias para preenchimento de falhas em dados pluviométricos. Sustentare, v. 2, n. 1, p. 198-210, 2018.

KHOSRAVI, G. et al. A Modified distance-weighted approach for filling annual precipitation gaps: application to different climates of Iran. Theoretical and Applied Climatology, v. 119, n. 1-2, p. 33-42, 2015. https://dx.doi.org/10.1007/s00704-014-1091-5

KRUSKAL, W. H.; WALLIS, W. A. Use of ranks in on-criterion variance analyses. Journal of the American Statistical Association, v. 47, n. 260, p. 583-621, 1952.

LIMA, J. S. de S. et al. Variabilidade temporal da precipitação mensal em Alegre - ES. Revista Ciência Agronômica, v. 39, n. 02, p. 327-332, 2008.

NAGHETtinI, M.; PINTO, E. J. A. Hidrologia Estatística. Belo Horizonte: Serviço Geológico do Brasil-CPRM, 2007. 381p.

OLIVEIRA, L. F. C. et al. Comparação de metodologias de preenchimento de falhas de séries históricas de precipitação pluvial anual. Revista Brasileira de Engenharia Agrícola e Ambiental, v. 14, n. 11, p. 1186-1192, 2010.

PEREIRA, D. R. et al. Hydrological simulation using SWAT model in a headwater basin in southeast Brazil. Engenharia Agrícola, v. 34, n. 4, p. 789-799, 2014. https://doi.org/10.1590/S0100-69162014000400018 
SANTOS, B. F.; TREVISAN, D. P.; MOSCHINI, L. E. Avaliação da vulnerabilidade ambiental do município de Itirapina - SP. Geo Temas, v. 8, n. 1, p. 42-59, 2018a. https://doi.org/10.33237/geotemas.v8i1.2822

SANTOS, B. C.; SANCHES, R. G.; SOUZA, P. H. A dinâmica atmosférica no verão 2013 2014 no município de Itirapina/SP e sua caracterização pluviométrica utilizando anos padrões. Caminhos de Geografia, v. 19, n. 68, p. 1-18, 2018b. https://doi.org/10.14393/RCG196801

SILVA, C. E. F. et al. Plano de manejo integrado das unidades de Itirapina. 2006. Available at:

https://smastr16.blob.core.windows.net/iflorestal/2013/03/Plano_de_Manejo_EEc_Itira pina.pdf. Access: November $14^{\text {th }}, 2020$.

SHAPIRO, S. S.; WILK, M. B. An analysis of variance test for normality (complete samples). Biometrika, v. 52, p. 591-611, 1965.

SHEPARD, D. A two-dimensional interpolation function for irregularly spaced data. In: NATIONAL CONFERENCE OF THE ASSOCIATION FOR COMPUTING MACHINERY, 23., 1968. Proceedings... New York: ACM, 1968. p. 517-524.

SOUZA, V.; GALVANI E. Distribuição Espaço Temporal Da Precipitação Pluvial E Sua Interação Com O Relevo Na Bacia Do Rio Jacaré Guaçu (SP). Ciência e Natura, v. 39, p. 110-124, 2017. https://dx.doi.org/10.5902/2179460X27334

TEEGAVARAPU, R. S. V.; CHANDRAMOULI, V. Improved weighting methods, deterministic and stochastic data-driven models for estimation of missing precipitation records. Journal Of Hydrology, v. 312, n. 1-4, p. 191-206, 2005. https://doi.org/10.1016/j.jhydrol.2005.02.015

TRIOLA, M. Introdução a estatística. Rio de Janeiro: LTC, 2008. 722 p.

WANDERLEY, H. S.; AMORIM, R. F. C.; CARVALHO, F. O. Interpolação espacial de dados médios mensais pluviométricos com redes neurais artificiais. Revista Brasileira de Meteorologia, v. 29, n. 3, p. 389-396, 2014. https://doi.org/10.1590/0102-778620130639

YOUNG, K. C. A Three-way model for interpolating monthly precipitation values. Monthly Weather Review, v. 120, n. 11, p. 2561-2569, 1992. https://doi.org/10.1175/15200493(1992)120<2561:ATWMFI>2.0.CO;2 